Report of Investigations 2006-2

Version 1.0.1

\title{
BEDROCK GEOLOGIC MAP OF THE LIBERTY BELL AREA, FAIRBANKS A-4 QUADRANGLE, BONNIFIELD MINING DISTRICT, ALASKA
}

by

J.E. Athey, R.J. Newberry, M.B. Werdon,

L.K. Freeman, R.L. Smith, and D.J. Szumigala

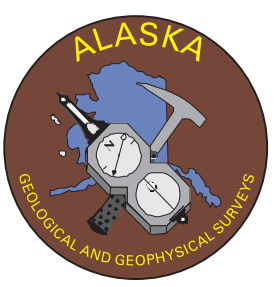

Published by

STATE OF ALASKA

DEPARTMENT OF NATURAL RESOURCES

DIVISION OF GEOLOGICAL \& GEOPHYSICAL SURVEYS 
Report of Investigations 2006-2

Version 1.0.1

\title{
BEDROCK GEOLOGIC MAP OF THE LIBERTY BELL AREA, FAIRBANKS A-4 QUADRANGLE, BONNIFIELD MINING DISTRICT, ALASKA
}

\author{
by \\ J.E. Athey, R.J. Newberry, M.B. Werdon, \\ L.K. Freeman, R.L. Smith, and D.J. Szumigala
}

2006

This DGGS Report of Investigations is a final report of scientific research. It has received technical review and may be cited as an agency publication. 


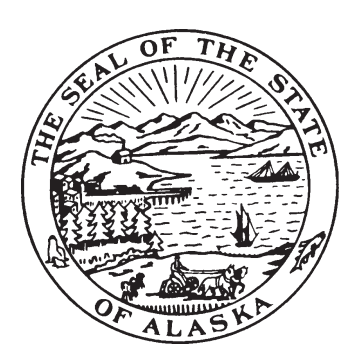

STATE OF ALASKA

Frank Murkowski, Governor

DEPARTMENT OF NATURAL RESOURCES

Mike Menge, Commissioner

\title{
DIVISION OF GEOLOGICAL \& GEOPHYSICAL SURVEYS Robert F. Swenson, Acting State Geologist and Acting Director
}

Division of Geological \& Geophysical Surveys publications can be inspected at the following locations. Address mail orders to the Fairbanks office.

\author{
Alaska Division of Geological \\ \& Geophysical Surveys \\ 3354 College Road \\ University of Alaska Anchorage Library \\ 3211 Providence Drive \\ Fairbanks, Alaska 99709-3707 \\ Anchorage, Alaska 99508 \\ Elmer E. Rasmuson Library \\ University of Alaska Fairbanks \\ Fairbanks, Alaska 99775-1005 \\ Alaska Resource Library \\ and Information Services (ARLIS) \\ 3150 C Street, Suite 100 \\ Anchorage, Alaska 99503
}

\author{
Alaska State Library \\ State Office Building, 8th Floor \\ 333 Willoughby Avenue \\ Juneau, Alaska 99811-0571
}

This publication released by the Division of Geological \& Geophysical Surveys was produced and printed in Fairbanks, Alaska at a cost of \$23 per copy. Publication is required by Alaska Statute 41, "to determine the potential of Alaskan land for production of metals, minerals, fuels, and geothermal resources; the location and supplies of groundwater and construction materials; the potential geologic hazards to buildings, roads, bridges, and other installations and structures; and shall conduct such other surveys and investigations as will advance knowledge of the geology of Alaska." 


\section{CONTENTS}

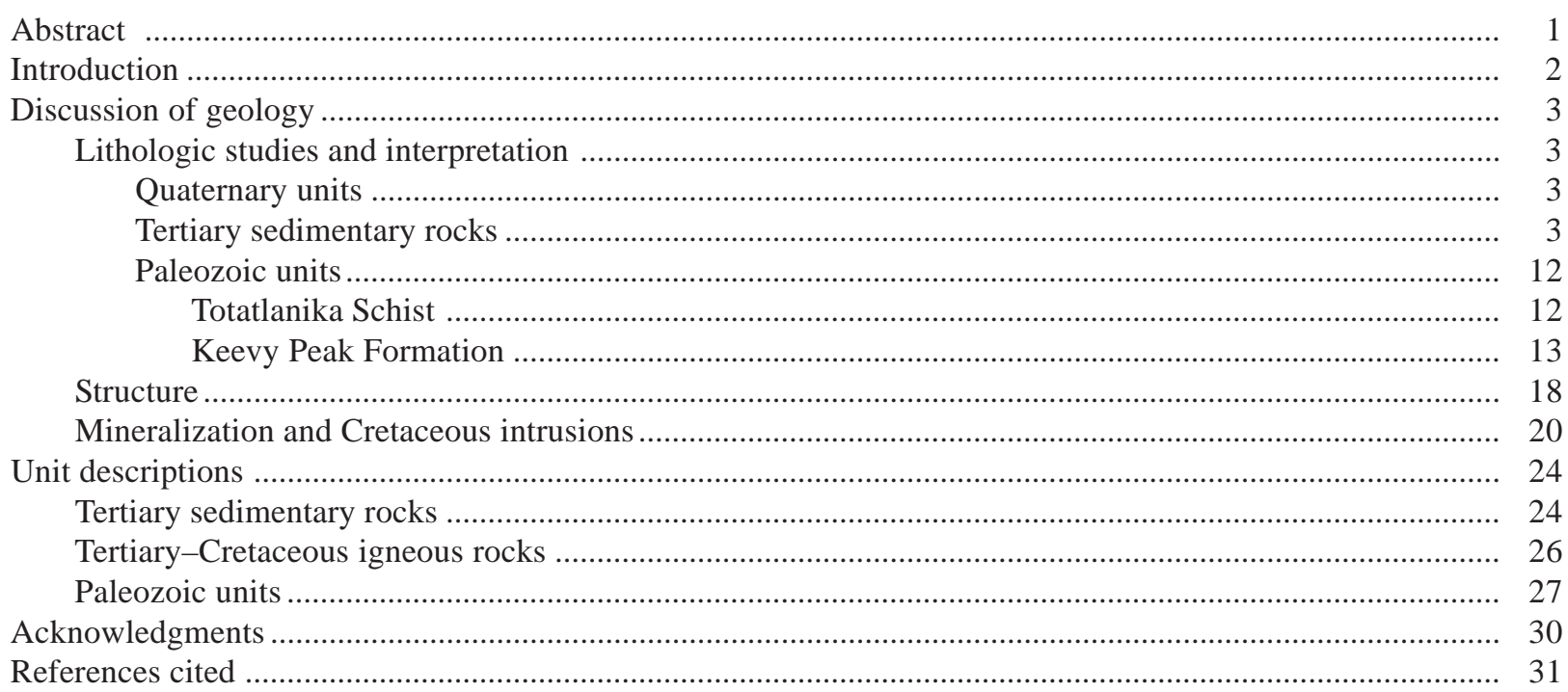

\section{TABLES}

Table 1. Clustered items shown with their corresponding distance coefficients ............................................. 5

2. Normalized major point-count parameters of Tertiary sandstone ....................................................... 8

3. Qualitative comparison of montmorillonite and kaolinite content in Nenana Gravel and Usibelli Group clays

4. Pollen samples from random outcrop locations in the Tertiary Usibelli Group ................................. 11

5. Interpreted ${ }^{40} \mathrm{Ar} /{ }^{39} \mathrm{Ar}$ ages for selected samples from the Liberty Bell area, Fairbanks A-4 Quadrangle ........................................................................................................ 14

6. Placer gold composition from Little Moose Creek ………………....................................................... 22

\section{FIGURES}

Figure 1. Location figure showing the map and airborne geophysical survey areas in relation to rural communities, transportation systems, and utilities

2. Dendrogram showing statistical distance between samples (or degree of dissimilarity) versus groupings of similarly composed Tertiary sandstone (1) s. . 1 4

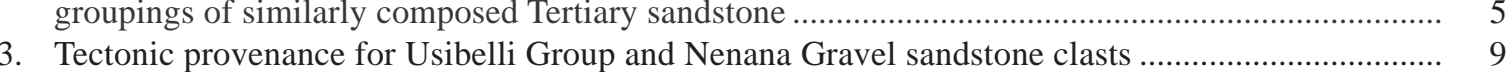

4. Paleocurrent directions measured from cross-beds in the Liberty Bell area ....................................... 10

5. Summary of SHRIMP U-Pb ages from Paleozoic rocks collected in the Alaska Range Foothills ..... 13

6. Discriminant analysis of metasedimentary and meta-igneous rocks from the Liberty Bell area ........ 16

7. Tectonic setting for igneous and meta-igneous rocks from the Liberty Bell area as indicated by trace-element discrimination diagrams ..................................................................... 19

8. Gridded ore-element data from rock samples in the Liberty Bell Mine area ...................................... 21

9. Typical(?) gold composition patterns for Interior Alaskan intrusion-related deposits ........................ 23 


\section{APPENDICES}

Appendix A. Geochemical analyses of Paleozoic samples .....................................................................

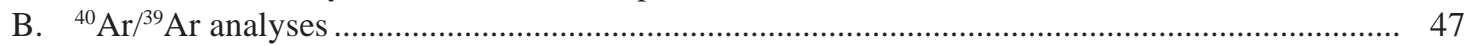

C. Grain-mount petrology of Tertiary samples ……........................................................................ 59

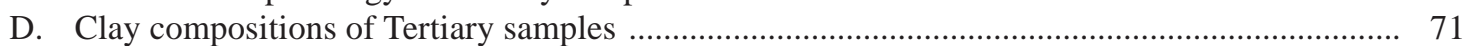

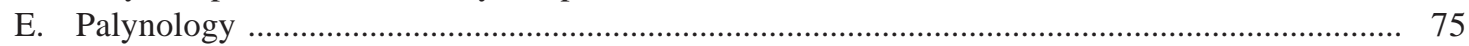

F. Energy and geochemical analyses of coal and coal ash .............................................................. 83

G. Alaska Resource Data File occurrences in the southern half of the Fairbanks A-4 Quadrangle

\section{SHEET}

(in envelope)

Bedrock geologic map of the Liberty Bell area, Fairbanks A-4 Quadrangle, Bonnifield mining district, Alaska 


\title{
BEDROCK GEOLOGIC MAP OF THE LIBERTY BELL AREA, FAIRBANKS A-4 QUADRANGLE, BONNIFIELD MINING DISTRICT, ALASKA
}

\author{
by \\ Jennifer E. Athey ${ }^{1}$, Rainer J. Newberry², Melanie B. Werdon ${ }^{1}$, \\ Lawrence K. Freeman ${ }^{1}$, Robin L. Smith ${ }^{1}$, and David J. Szumigala ${ }^{1}$
}

\begin{abstract}
The geology of the Liberty Bell area, located in the northern Alaska Range foothills, comprises Devonian metasedimentary and meta-igneous rocks of the Totatlanika Schist and Keevy Peak formations, Cretaceous and Tertiary igneous rocks, and overlying unconsolidated Tertiary sedimentary rocks of the Usibelli Group and the younger Nenana Gravel. Broad folds and high-angle faults form and expose east-westtrending bands of Paleozoic and Tertiary rocks across the map area. Ore-element geochemistry and geologic mapping suggest the east-west-oriented faults are reactivated (latest apparent movement is reverse on north-dipping $\left[57-90^{\circ}\right]$ faults in the Liberty Bell Mine area); northeast- and northwest-trending structures may be activated fracture sets. Thrust faults postulated to accommodate north-directed compression from active uplift of the Alaska Range were not recognized in the map area, but they may be present at depth.

Tertiary Usibelli Group and Nenana Gravel outcrops commonly contain interbedded sand and gravel with no distinctive lithologies within or between the formations. A petrographic study of sand composition yielded data that can be used to classify the formations. Sand from the Nenana Gravel contains a diverse population of unstable rock fragment compositions while the Usibelli Group sand contains a higher percentage of stable rock fragments. The percentage of stable rock fragments increases down-section in the Usibelli Group. This relationship is also recognized by previous workers in the Suntrana Creek area to the south, where a similar geologic section exists. Paleotopographic differences may be responsible for discrepancies in the Usibelli Group between the Suntrana Creek section and the Liberty Bell area units, including contrasting paleocurrent directions (south- versus west-directed), the absence of the Grubstake Formation, and coarsening of the Lignite Creek Formation to the north.

Bedrock units California Creek and Moose Creek (members of the Totatlanika Schist) and the Keevy Peak Formation are composed of metasedimentary and lesser meta-igneous rocks. The similar-looking rocks can be distinguished with a combination of trace-element compositions ( $\mathrm{Nb}+\mathrm{Y}<50 \mathrm{ppm}=$ metasedimentary; $\mathrm{Nb}+\mathrm{Y}>50 \mathrm{ppm}=$ meta-igneous), modal composition, and relict textures (embayed crystals, graded bedding, grain sorting, etc.) as seen on cut surfaces or in thin sections. The Keevy Peak Formation is composed of graphitic quartzite and metamorphosed quartz wacke. The California Creek Member is primarily composed of metamorphosed arkosic wacke and other minor metasedimentary rocks, but it also contains metamorphosed, generally hypabyssal, granitic intrusions and rare metabasite. The Moose Creek Member previously mapped in the Fairbanks A-4 Quadrangle is a metamorphosed granitic intrusion indistinguishable from the meta-igneous units within the California Creek Member.

An east-west-trending band of metasedimentary (quartzite, graphitic quartzite, and metawacke) and meta-igneous (metamorphosed felsic and mafic intrusions and flows[?]) rocks mapped within the California Creek member hosts the Liberty Bell Mine, the major plutonic-related gold deposit in the area. Mineralization occurs as pyrrhotite \pm gold \pm arsenopyrite + actinolite + biotite skarn (metasomatized carbonatealtered metabasite) and arsenopyrite \pm gold \pm bismuth minerals \pm stibnite \pm tourmaline + quartz veins and replacements. A positive aeromagnetic anomaly ( 8 by $5.5 \mathrm{~km}$ ) and the extent of hornfels and hydrothermal alteration suggest the Liberty Bell Mine area is underlain by a large pluton. This body is expressed on the surface by granite and granodiorite dikes with consistent ${ }^{40} \mathrm{Ar} /{ }^{39} \mathrm{Ar}$ and K-Ar ages of approximately 92-93 Ma. A comparison of placer gold fineness ( $\sim 30)$, estimated temperature of mineral assemblage formation $\left(300-350^{\circ} \mathrm{C}\right)$, and extent of hornfels with other plutonic-related deposits in Interior Alaska suggests that the pluton is emplaced approximately $300-1,200$ m below the surface. Given the depth of the pluton, viable exploration targets in the mine area include replacement/skarn and structurally controlled mineralization, both of which are documented at Liberty Bell.
\end{abstract}

\footnotetext{
${ }^{1}$ Alaska Division of Geological \& Geophysical Surveys, 3354 College Rd., Fairbanks, Alaska 99709-3707

Email for Jennifer Athey: Jennifer_Athey@dnr.state.ak.us

${ }^{2}$ Department of Geology \& Geophysics, University of Alaska, P.O. Box 755780, Fairbanks, Alaska 99775-5780
} 


\section{INTRODUCTION}

This booklet accompanies Bedrock geologic map of the Liberty Bell area, Fairbanks A-4 Quadrangle, Bonnifield mining district, Alaska, a 1:50,000-scale map covering the southern half of the Fairbanks A-4 Quadrangle. The booklet contains unit descriptions and supporting information. The map area covers the southern 340 square $\mathrm{km}$ of the Liberty Bell airborne geophysical survey (Burns and others, 2002). This project is part of the State's Airborne Geophysical/Geological Mineral Inventory program, which seeks to delineate mineral zones on Alaska state lands that: (1) have major economic value; (2) can be developed in the short term to provide high-quality jobs for Alaska; and (3) will provide diversification of the State's economic base. New geologic mapping in historic mining areas such as the western Bonnifield district that incorporates interpretation of high-quality geophysical data will provide information that could lead to renewed exploration and mine development.

The Liberty Bell map area is located $96 \mathrm{~km}$ southwest of Fairbanks and $320 \mathrm{~km}$ north of Anchorage (fig. 1). The map area is situated in the western half of the Bonnifield mining district, which extends across the north flank of the Alaska Range for approximately $65 \mathrm{~km}$. Approximately 85,000 ounces of placer gold have been mined from the region since 1903 (Szumigala and Hughes, 2005), with most production between the
Totatlanika River and Ferry, Alaska. Eleven placer gold mines (three active) and eight metallic lode occurrences are located in the map area (Freeman and Schaefer, 2001). The Liberty Bell gold mine is the major lode occurrence known in the mining district. The Liberty Bell property has an announced potential of 250,000 ounces of gold, with inferred resources of 1,240,000 tons at an average grade of 0.1 ounces of gold per ton at the Mine Zone (Freeman and Schaefer, 2001). The map area also covers the northern edge of the Nenana coal basin. Tertiary units contain coal resources and the possibility of shallow natural gas. Mineral, shallow natural gas, and coal targets within the map area have recently been selected or are actively being explored by industry.

The western part of the mining district is highly accessible, with extensive infrastructure for mineral development (fig. 1). Alaska's main ground transportation corridor between Anchorage and Fairbanks, containing the Parks Highway and Alaska Railroad, runs 8 km west of the western edge of the study area. A well maintained, 16-km-long dirt road (informally known as the Ferry Road) and numerous spur trails exist between the Liberty Bell Mine near the center of the map area and Ferry. In addition, two high-voltage interties, which run parallel to the Parks Highway and railroad corridors, connect the Healy Power Plant (located $19 \mathrm{~km}$ south of the map area) to the power grid that provides electricity to Fairbanks, Anchorage, and numerous railbelt communities.

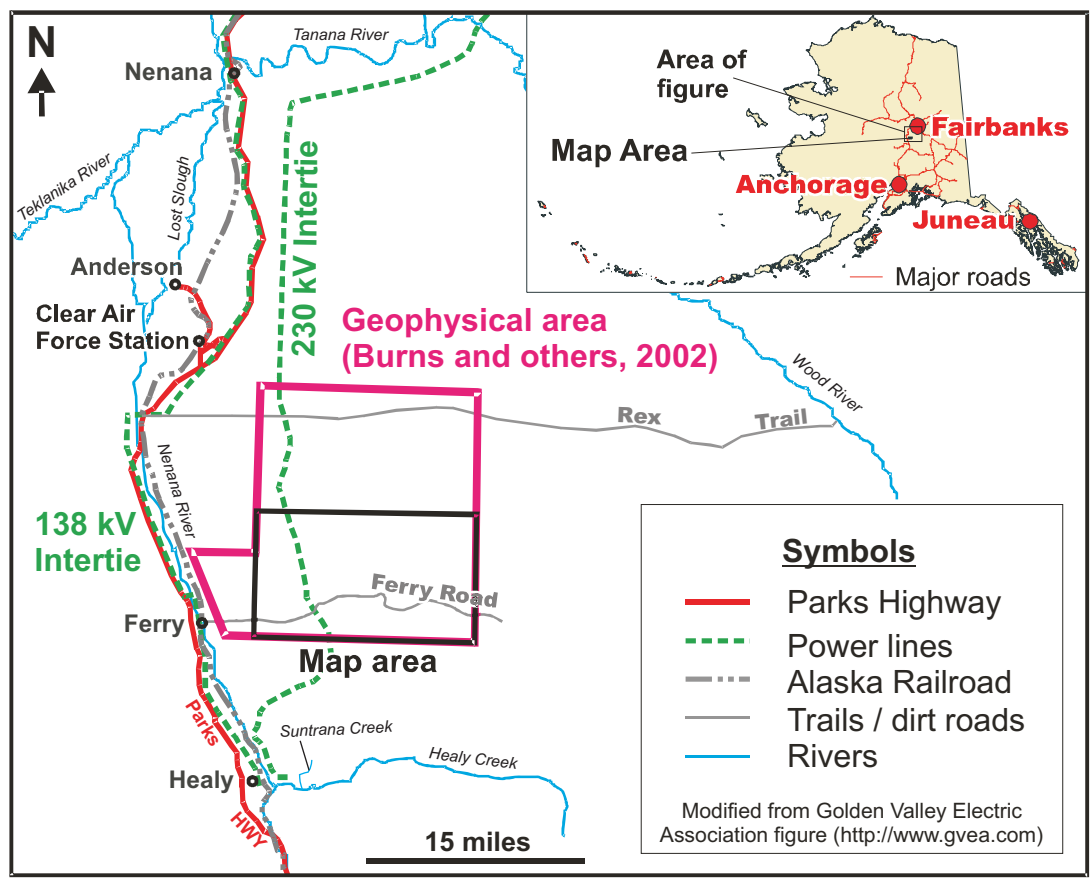

Figure 1. Location figure showing the map and airborne geophysical survey areas in relation to rural communities, transportation systems, and utilities. 
During July 2005, personnel from the Alaska Division of Geological \& Geophysical Surveys (DGGS) and the University of Alaska Fairbanks spent approximately 105 person days conducting field work in the Liberty Bell area. A variety of data were used to create the geologic map. Total field magnetic and electromagnetic geophysical data (Burns and others, 2002) aided our bedrock mapping, especially in areas covered by vegetation and unconsolidated Quaternary deposits. For example, our interpretation of the geophysical data reveals locations of pyrrhotite-bearing hornfels, burned coal and sedimentary units, and structures that would otherwise remain undetected by conventional surface mapping methods.

Preliminary interpretation of air photos allowed identification of linear features that were utilized in the structural interpretation. Air photos used in this study include color-infrared photographs at a scale of approximately 1:63,360 that were taken in August 1981. These linear features were identified during a simultaneous surficialgeologic study being conducted by DGGS in the field area largely from interpretation of aerial photography, revision of historical data, and limited field work. From this additional study, we anticipate the completion of a comprehensive-geologic and a surficial-geologic map in winter 2006. The comprehensive geologic map will depict Paleozoic bedrock geology, covered by Tertiary and Quaternary units.

Geologic units are defined by field observations and analysis of samples collected at more than 1,405 stations in 2005. Paleozoic rocks and younger, unmetamorphosed igneous rocks were primarily defined by chemical composition, examination of hand samples, and petrography. Approximately 280 samples were analyzed for major-and minor-oxide and trace elements by a commercial analytical laboratory (Athey and others, 2005) and the University of Alaska Fairbanks (appendix A). These data are used to suggest possible protoliths of metamorphosed and altered rocks, identify types of alteration, and assign trace-element indicated tectonic settings to igneous and meta-igneous rocks. Unit descriptions are also based on the petrographic examination and modal analysis of 169 thin sections. Six ${ }^{40} \mathrm{Ar} /$ ${ }^{39} \mathrm{Ar}$ ages (table 5; appendix B) were used to constrain timing of igneous events, mineralization, and metamorphism in the Liberty Bell Mine area. (Liberty Bell Mine area is defined as the western, rounded portion of the area outlined on sheet 1 as underlain by the subsurface pluton [see 'Map Symbols']; area is outlined in figure 'Location Map of the Liberty Bell Mine area and hill VABM Coal' on sheet 1 . The area coincides with a donut-shaped, aeromagnetic high [Burns and others, 2002]). Tertiary units were differentiated by a combination of field observations, cluster analysis of sand grain composition, clay composition, and palynology. Sixty grain mounts of Tertiary sand were point-counted (appendix C) in order to compare sand composition. Clay compositions were determined by $\mathrm{X}$-ray diffraction for 65 samples of unconsolidated rock (appendix D). Pollen was identified and counted in 15 samples of fine-grained Tertiary sedimentary rock and coal (appendix E).

To evaluate the mineral-resource potential of the Liberty Bell area, 116 samples of visibly mineralized rock, or rock exhibiting features associated with mineralization, were analyzed for geochemical trace elements (Athey and others, 2005). To evaluate the energy-resource potential of the Liberty Bell area, 21 coal samples were analyzed for energy values (proximate and ultimate analyses, BTU, etc.) and trace elements of their ash (appendix F). The composition of a placer gold sample was determined by X-ray fluorescence (table 6). Historical and mineral industry data were incorporated into the data set wherever possible. Locations and descriptions of Alaska Resource Data File occurrences (Freeman and Schafer, 2001) are compiled in appendix G. Unpublished mapping conducted in 1994 by DGGS personnel, geologic maps created by mineral exploration companies, and industry geochemical data were utilized in this study (Freeman and others, 1987; Puchner and Freeman, 1988; Galey and others, 1993; Bidwell, 1994; DGGS, 1994). We especially thank the Blair family, Wallace O. Turner, II, and Jim Roland for allowing us to compile and publish industry geologic information held by them, which greatly enhanced the quality of our map and interpretations.

\section{DISCUSSION OF GEOLOGY LITHOLOGIC STUDIES AND INTERPRETATIONS}

\section{QUATERNARY UNITS}

A diverse suite of Quaternary materials, including glacial, alluvial, landslide, fan, and swamp deposits, discontinuously overlie older units in the area. Placer deposits of unknown age (Holocene or Pleistocene) and character are also located throughout the map area, which suggests that multiple sources of lode gold are exposed and shedding detritus. The placer gold has two morphologies, one is smooth and rounded, probably reworked from older Quaternary placers or possibly from Tertiary units, and the other is pristine gold presumably eroded from nearby lode sources (R.W. Flanders, oral commun., 2005).

\section{TERTIARYSEDIMENTARYROCKS}

Tertiary Nenana gravel and sand derived from the post-Middle Miocene uplift of the Alaska Range (Plafker and others, 1992) overlies older, poorly lithified, Tertiary continental clastic rocks of the coal-bearing Usibelli 
Group. The Usibelli Group unconformably overlies Paleozoic metamorphic rocks. Wahrhaftig and others (1969) separated the Usibelli Group into five formations: Grubstake, Lignite Creek, Suntrana, Sanctuary, and Healy Creek (youngest to oldest, respectively). In the map area, two of the five Usibelli Group formations, the Grubstake and Sanctuary Formations, were not recognized. The Suntrana Formation south of the map area contains known surface-mineable coal reserves in excess of 100 million tons that are currently being processed at the Usibelli Coal Mine east of Healy (http://www. usibelli.com/).

Tertiary outcrops were mapped by comparison to the Suntrana Creek section, located $15 \mathrm{~km}$ south of the map area, where the entire Usibelli Group and a large portion of the Nenana Gravel are exposed (Wahrhaftig, 1987). Unlike the excellent exposures of the Tertiary section in the Suntrana Creek area, Tertiary units in the map area are poorly exposed and crop out in about 2 percent of the map area; outcrops average $\sim 5 \mathrm{~m}$ in width and $\sim 5$ $\mathrm{m}$ in height. No unit is completely exposed at any location in the map area, which severely hinders correlating units between locations. Because outcrops are rare and gravel lag deposits are common on the surface, Tertiary samples were collected in pits at least 0.3 meters deep, and commonly 0.5 to more than a meter deep. Also unlike the Suntrana Creek section, the Tertiary stratigraphic section in the map area is rarely complete. Entire formations are frequently missing from the section, possibly from deposition on an irregular topographic surface and differential erosion.

Lack of exposures, complete sections, and marker units such as the distinctive shale units, Grubstake and Sanctuary Formations, hindered the authors' ability to confidently assign a particular formation to a field station. In order to refine or confirm the identity of the Tertiary units, field calls were supplemented by cluster analysis of sand modal compositions and comparison of sand compositions, clay compositions, and pollen taxa with other data sets from the same units. Future study of the Tertiary units could include additional coal energy and ash trace-element analyses and comparison of these compositions to more comprehensive data sets.

Sixty grain mounts of unconsolidated sandstone were point-counted to determine sand composition using the methodology of Decker (1985) and the "traditional” methodology of Ingersoll and others (1984). Hierarchical cluster classification was used to combine the samples into groups in a relatively unbiased manner. Davis (1986) describes hierarchical cluster analysis as an iterative process where similar samples are successively joined together. A matrix is computed for the total number of samples (n), which contains coefficients of similarity (referred to here as coefficients of statistical distance) for each pair of samples. The pair with the lowest distance coefficient is more similar than any other pair in the data set; these samples are grouped together into a 'cluster.' A new mean value is computed for the new cluster, and the matrix is recomputed for ' $n$ - 1 ' individual samples and one cluster. The process is repeated until all individual samples are combined into the minimum number of clusters requested. Clusters are then arranged on a dendrogram vertically according to their similarity to other clusters, and the general value of the distance coefficients used for joining the clusters are also displayed. For the current project, the cluster analyses for the 60 grain mounts were calculated using the computer program SPSS and an algorithm using the between-group (average) linkage method where the interval measured is the squared Euclidean distance. The program was instructed to arrange all individual samples into 15 through 2 clusters; since only four geologic units (Nenana Gravel, Lignite Creek, Suntrana, and Healy Creek Formations) were expected to cluster from the individual samples, it was assumed that a maximum of 15 clusters would capture the significant variability in the data set.

This cluster analysis was performed on various permutations of the point-counted sand composition components quartz, feldspar, sedimentary rock fragments, volcanic rock fragments, metamorphic rock fragments, plutonic rock fragments, detrital minerals, and undetermined grains. To determine which analysis was the best fit to the data, individual cluster members (where the samples were grouped into 15 through 2 clusters for each analysis) were plotted on the map and visually compared with the field-mapped Tertiary unit polygons. The following method and variables were used in the analysis that produced cluster results that most closely matched the expected formations: totals of quartz, feldspar, sedimentary rock fragments, volcanic rock fragments, metamorphic rock fragments, plutonic rock fragments, detrital minerals, and undetermined grains were normalized to 100 percent, and all components except detrital minerals and undetermined grains were selected as variables. Only this best-fit analysis will be discussed here.

The dendrogram (fig. 2) shows the results of the best cluster analysis achieved (table 1 ). The cluster analysis confirmed that most of the Tertiary unit field determinations were correct. Approximately 85 percent (50 of 60) of the samples were assigned by the cluster analysis to their field-determined formation. Samples that were mapped as a different unit from the one in which they were grouped in the cluster analysis were changed on the map to reflect their assigned cluster analysis formation (except sample 2005JEA249A, see details below). The cluster analysis is interpreted to have combined 57 of the 60 samples into seven main clusters, including two Healy Creek Formation subgroups (H1 and H2), Suntrana Formation group (S), two Lignite Creek Forma- 
Coefficient of Distance

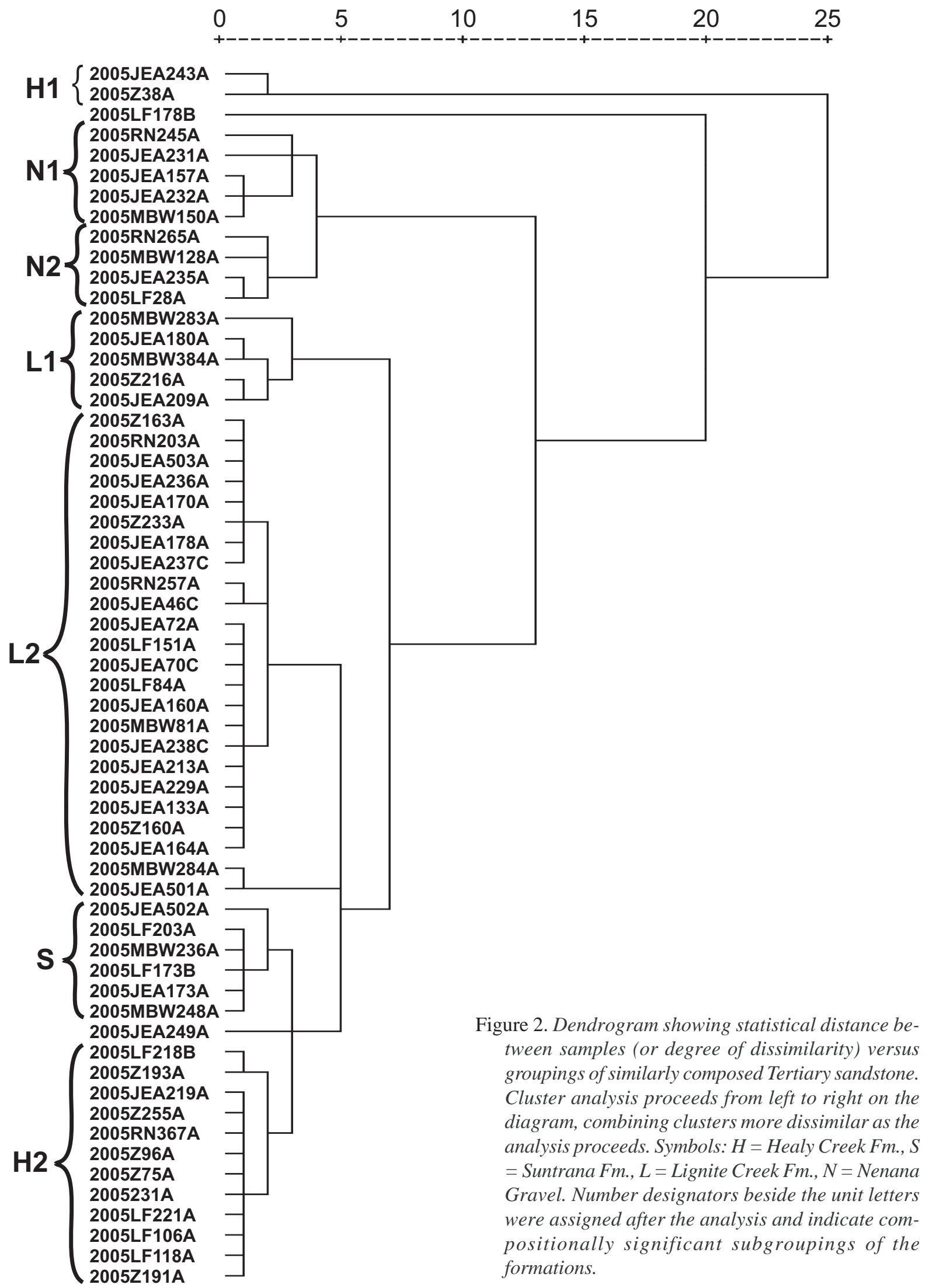


tion subgroups (L1 and L2), and two Nenana Gravel subgroups (N1 and N2). The Healy Creek subgroup H1 contains only two members, but the samples' unique compositions appear to have a geologic basis. Cluster H1 and adjacent sample 2005LF178B (fig. 2) will be discussed below. The cluster analysis subgroupings of these formations reflect significant compositional differences in the grain mounts; none of those compositional differences (or subgroups) were recognized in the field.

Strong homogeneity is apparent for samples within clusters H2, S, N2, and 22 of 24 samples that clustered early into the L2 cluster. These clusters each formed around a distance coefficient of 2 (table 1). Sand modal compositions of S and $\mathrm{H} 2$ in particular are very similar; $\mathrm{S}$ and $\mathrm{H} 2$, the first two units to combine into one cluster (SH2), joined at a distance coefficient of 3. Sample 2005JEA249A combined with cluster H2 before the S and $\mathrm{H} 2$ clusters merged. This sample, a silicified conglomerate with a high percentage of metamorphic clasts, was difficult to point count. In this particular case, the sample was left in the Suntrana Formation as it was origi- nally mapped, because its field-determined formation was considered more reliable than its formation suggested by statistical analysis. In contrast with these relatively homogeneous clusters, the L1 and N1 subgroups show more variation in sand modal composition.

As the cluster analysis progressed, the remaining main subgroups (L1, L2, N1, and N2) each formed before any other units combined. L2 and L1 were added at distance coefficients 5 and 7, respectively, to the SH2 cluster. Excluding cluster $\mathrm{H} 1$ and sample 2005LF178B at the top of the dendrogram (fig. 2), all of the Usibelli Group clusters combined around a distance coefficient of 7 . The order of clustering indicates that L2 is more similar in composition to the combination of Healy Creek and Suntrana Formations than it is to the rest of the Lignite Formation. The Nenana Gravel subgroup N2 clustered at a distance coefficient of 2, N1 clustered at 3, and N1 and N2 combined into one cluster around 4; thus, the data suggest the Nenana Gravel is more homogeneous than the Usibelli Group as a whole (coefficient of 7). The Nenana Gravel subgroups remain distinct from the

Table 1. Clustered items shown with their corresponding distance coefficients for the last 17 clusters formed. For example, line one can be read as "Most of L2 clustered at a distance coefficient of about $\underline{2}$ and that cluster was one of $\underline{17}$ clusters grouped in the data set." Symbols: $H=$ Healy Creek Fm., S = Suntrana Fm., L = Lignite Creek Fm., $N=$ Nenana Gravel. Number designators beside the unit letters were assigned after the analysis and indicate compositionally significant subgroupings of the formations. Specific sample numbers are in parentheses. See figure 2 for the dendrogram of the full hierarchical classification.

\begin{tabular}{lcc} 
New Cluster Formed & $\begin{array}{c}\text { Approximate } \\
\text { Coefficient of } \\
\text { Distance }\end{array}$ & $\begin{array}{c}\text { Number } \\
\text { of } \\
\text { Clusters }\end{array}$ \\
Most of L2 & 2 & 17 \\
N2 & 2 & 16 \\
S & 2 & 15 \\
H2 & 2 & 14 \\
H1 & 2 & 13 \\
(2005JEA249A) joins H2 & 3 & 12 \\
\hline S joins H2 & 3 & 11 \\
(2005JEA231A) joins N1 & 3 & 10 \\
(2005RN245A) joins N1 & 3 & 9 \\
(2005MBW283A) joins L1 & 3 & 8 \\
N2 joins N1 to form Nenana Gravel & 4 & 7 \\
L2 & 5 & 6 \\
\hline SH2 joins L2 & 5 & 5 \\
L1 joins L2SH2 to form most of & & 4 \\
$\quad$ Usibelli Group & 7 & 3 \\
Nenana Gravel joins Usibelli Group & 13 & 2 \\
(2005LF178B) joins Nenana Gravel & & 1 \\
\hline + Usibelli Group & 20 & \\
H1 joins all other samples & 25 & \\
\hline
\end{tabular}


Usibelli Group until a distance value of 13, indicating that the sand modal composition of the Nenana Gravel is fairly different from the composition of the Usibelli Group.

Determining which cluster groupings are significant is largely subjective. As the analysis continues joining clusters, increasingly heterogeneous samples are combined to a point where the combined samples are not, in reality, related. Sudden increases in the distance coefficients indicate dissimilar groups are being joined that should really be left as separate clusters. An example of this is the fusion of sample 2005LF178B and H1 with the rest of the clusters at distance coefficients 20 and 25, respectively. Correct placement of sample 2005LF178B, a partially fused (coal-fired), quartz-rich sandstone, within the cluster hierarchy is problematic due to poor sample conditions making grain identification and counting difficult. The sample is considered to be from the Suntrana Formation, its field-mapped unit. Samples in H1 were mapped as Healy Creek Formation. Although the H1 cluster appears to be markedly different from any other samples in the data set (possibly reflecting poor data quality or errors), the two samples in this cluster, while containing extraordinarily high amounts of metamorphic rock fragments, have proportionally similar sand compositions to H2. A possible geologic explanation for this composition is discussed below.

In summary (excluding cluster $\mathrm{H} 1$ and sample 2005LF178B), the sand compositions of Healy Creek (H2), Suntrana, and most of the Lignite Creek (L2) Formations in the Usibelli Group are homogenous, and the formations are similar to each other. The sand compositions of the rest of the Lignite Creek Formation (L1) and the Nenana Gravel are more heterogeneous, and these formations are less similar to the bulk of the Usibelli Group. Lignite Creek 1, however, is still more similar to the Usibelli Group than it is to the Nenana Gravel. Given that the Nenana Gravel is compositionally distinct from the Usibelli Group, it is most similar to the Lignite Creek Formation and least similar to the Healy Creek Formation.

Sandstone compositions in the Tertiary section show several trends (table 2). Nenana Gravel is more compositionally heterogeneous than the Usibelli Group formations, and homogeneity progressively increases down-section. The dendrogram (fig. 2) shows this trend through its vertical arrangement of groups (except subgroup H1 and sample 2005LF178B), which approximates the formations in the stratigraphic section. The vertical arrangement of subgroups within a formation, however, does not necessarily have stratigraphic significance, but represents variations within the unit. Nenana Gravel $\left(\mathrm{Q}_{26} \mathrm{~F}_{11} \mathrm{~L}_{63} ; \mathrm{Qm}_{16} \mathrm{~F}_{11} \mathrm{Lt}_{73}\right)$ contains more lithics and less total quartz, monocrystalline quartz, and polycrystalline quartz than the Usibelli Group $\left(\mathrm{Q}_{53} \mathrm{~F}_{12} \mathrm{~L}_{35} ; \mathrm{Qm}_{36} \mathrm{~F}_{12} \mathrm{Lt}_{52}\right)$ (fig. 3). Healy Creek has more polycrystalline quartz than any of the other units, probably due to incorporation of fragments from the underlying Paleozoic rocks and other Yukon-Tanana terrane metamorphic rocks. The Nenana Gravel contains more sedimentary rock fragments (and non-chert sedimentary rock fragments; $\mathrm{Ls}_{65} \mathrm{Lp}_{14} \mathrm{Lm}_{22}$ ) and plutonic rock fragments than the Usibelli Group $\left(\mathrm{Ls}_{38} \mathrm{Lp}_{10} \mathrm{Lm}_{53}\right)$, and these lithics decrease progressively in abundance down-section through the entire Tertiary section. N2 contains almost twice as much chert as N1, and about three times as much chert as any formation in the Usibelli Group. Through the whole section, differences in the amounts of feldspar and volcanic rock fragments between units are subtle, and near the 95 percent confidence of the data (estimated confidence; Van der Plas and Tobi, 1965). While sedimentary and plutonic rock fragments increase progressively up-section, metamorphic rock fragments are more prevalent in the Usibelli Group. The increase of total quartz (Q), and especially polycrystalline quartz (Qp), in sandstones from the lower Usibelli Group suggests derivation from the nearby metamorphic rocks. In addition, subgroups L1 and H1 both contain large, immature populations of metamorphic rock fragments that are texturally and compositionally similar to the metasedimentary and meta-igneous units in the map area; these subgroupings are at least partially locally derived (basal conglomerates?). Lignite Creek and Healy Creek both unconformably overlie Paleozoic bedrock in a significant portion of the map area.

Sandstone compositions and related data from the Suntrana Creek section (Ridgway and others, 1999) are similar to sandstone compositions in the map area, supporting the correlation between the two areas (fig. 3). Because this study used the "traditional" point-counting method (Ingersoll and others, 1984; Decker, 1985) and Ridgway and others (1999) primarily reported data counted with the Gazzi-Dickinson method, most of the data are not directly comparable. Data from this study will have lower total quartz, feldspar, and detrital minerals counts and higher lithics counts than data from Ridgway and others (1999) (Ingersoll and others, 1984). Even so, most of the trends mentioned above hold true for both data sets. Ridgway and others (1999) also show that Nenana Gravel is lithic-rich and quartz-poor, and that these components progressively decrease and increase in abundance, respectively, down-section. Ridgway and others (1999) reported that feldspar and volcanic rock fragments increase in abundance progressively higher in the section, but they did not mention this same trend in sedimentary rock fragments.

The differences in lithic and total quartz contents between formations are readily apparent in figure 3 . The high percentage of unstable lithics in Nenana Gravel suggests a sediment source area such as an undissected arc, transitional arc, or recycled orogen having a diverse composition but high percentage of quartz-feldspar- 
bearing rocks (Dickinson and others, 1983). Evidence such as abundant conglomerate clasts from the Cantwell Formation and north-directed paleocurrent data (fig. 4) indicates the Alaska Range and rocks to the south are the source of the Nenana Gravel (Wahrhaftig, 1987). The high total quartz and moderate lithic content of the Usibelli Group suggests that it is sourced from a recycled orogen composed of sediments, metamorphic rocks, and lesser volcanic and plutonic rocks (Dickinson and others, 1983). The paleocurrent directions of the Lignite Creek and Suntrana Formations in the field area are predominately westward (fig. 4; Wahrhaftig and others, 1969), while they are south-directed in the Suntrana Creek area (Wahrhaftig and others, 1969; Ridgway and others, 1999). The change in paleocurrent direction may coincide with the northern extent of the Grubstake Formation and a change in Lignite Creek facies from coal-bearing to coarser-grained, non-coal bearing. This facies change and the northern extent of the Grubstake Formation are mapped by Wahrhaftig and others (1969) as cutting through the southwestern quarter of the map area. These lithologic discontinuities may be related to differences in paleotopography between this area and the Suntrana Creek area to the south. Wahrhaftig and others (1969)

Table 2. Normalized major point-count parameters of Tertiary sandstone. Formations, but not necessarily their subgroupings, are arranged in stratigraphic order. Raw normalized parameters: $Q m=$ monocrystalline quartz, $Q p$ = polycrystalline quartz, $F=$ total feldspar, $L v=$ volcanic rock fragments, $C=$ chert, $L m=$ metamorphic rock fragments, $L p=$ plutonic rock fragments. Calculated normalized parameters: $Q=Q p+Q m+$ quartz undifferentiated, $L s=$ sedimentary rock fragments + C. Abbreviation s.d. = standard deviation of $2 \sigma($ Van Der Plas and Tobi, 1965), $n=$ number of samples. See appendix C for raw data.

\begin{tabular}{|c|c|c|c|c|c|c|c|c|c|}
\hline Unit & $\% Q$ & & & $\% \mathbf{F}$ & $\% \mathbf{L v}$ & $\%$ Ls & & $\%$ Lm & $\% \mathbf{L p}$ \\
\hline Nenana Gravel Summary & 26.3 & $\begin{array}{c}\text { \%Qm } \\
16.6\end{array}$ & $\begin{array}{r}\% \text { Qp } \\
9.7\end{array}$ & 11.1 & 9.0 & 34.6 & $\begin{array}{l}\% \mathrm{C} \\
23.0\end{array}$ & 11.7 & 7.3 \\
\hline \multicolumn{10}{|c|}{$\begin{array}{l}\text { Nenana Gravel } 1 \\
n=5\end{array}$} \\
\hline average & 31.0 & 20.9 & 10.2 & 11.8 & 9.9 & 27.3 & 18.0 & 10.8 & 9.1 \\
\hline s.d. & 5.7 & 5.1 & 3.8 & 4.0 & 3.8 & 5.6 & 4.8 & 3.9 & 3.5 \\
\hline \multicolumn{10}{|l|}{$\begin{array}{l}\text { Nenana Gravel } 2 \\
n=4\end{array}$} \\
\hline average & 20.3 & 11.2 & 9.0 & 8.2 & 7.8 & 43.8 & 29.3 & 12.8 & 5.0 \\
\hline s.d. & 5.1 & 4.0 & 3.5 & 3.4 & 3.2 & 6.2 & 5.7 & 4.1 & 2.5 \\
\hline Usibelli Group Summary & 54.9 & 37.0 & 17.9 & 12.7 & 4.7 & 10.5 & 7.3 & 14.6 & 2.7 \\
\hline \multicolumn{10}{|c|}{$\begin{array}{l}\text { Lignite Creek } 1 \\
\mathrm{n}=5\end{array}$} \\
\hline average & 43.0 & 25.3 & 17.7 & 8.7 & 3.5 & 12.5 & 9.4 & 31.2 & 1.1 \\
\hline s.d. & 4.2 & 5.5 & 4.8 & 3.4 & 2.0 & 4.1 & 3.5 & 5.8 & 1.4 \\
\hline \multicolumn{10}{|l|}{$\begin{array}{l}\text { Lignite Creek } 2 \\
n=24\end{array}$} \\
\hline average & 48.7 & 32.6 & 16.1 & 16.7 & 7.7 & 12.2 & 8.4 & 10.2 & 4.5 \\
\hline s.d. & 6.3 & 5.8 & 4.6 & 4.6 & 3.1 & 4.8 & 3.5 & 3.8 & 2.4 \\
\hline Lignite Creek Fm. Summary & 47.7 & 31.3 & 16.4 & 15.3 & 7.0 & 12.3 & 8.6 & 13.9 & 3.9 \\
\hline \multicolumn{10}{|l|}{$\begin{array}{l}\text { Suntrana Fm. } \\
n=6\end{array}$} \\
\hline average & 64.6 & 50.7 & 14.0 & 15.3 & 3.8 & 9.8 & 6.1 & 5.5 & 1.0 \\
\hline s.d. & 6.0 & 6.3 & 4.4 & 4.6 & 2.1 & 3.8 & 3.0 & 2.8 & 1.3 \\
\hline \multicolumn{10}{|l|}{$\begin{array}{l}\text { Healy Creek } 1 \\
n=2\end{array}$} \\
\hline average & 19.6 & 11.2 & 8.3 & 9.8 & 0.4 & 6.1 & 5.2 & 64.1 & 0.0 \\
\hline s.d. & 5.0 & 4.0 & 3.5 & 3.8 & 0.8 & 3.0 & 2.8 & 6.1 & 0.0 \\
\hline \multicolumn{10}{|l|}{$\begin{array}{c}\text { Healy Creek } 2 \\
n=13\end{array}$} \\
\hline average & 71.7 & 47.2 & 24.5 & 6.4 & 0.5 & 7.6 & 5.4 & 12.9 & 1.0 \\
\hline s.d. & 5.7 & 6.3 & 5.4 & 3.1 & 0.9 & 3.4 & 2.9 & 4.2 & 1.3 \\
\hline Healy Creek Fm. Summary & 64.8 & 42.4 & 22.4 & 6.8 & 0.5 & 7.4 & 5.3 & 19.8 & 0.9 \\
\hline
\end{tabular}


(A)
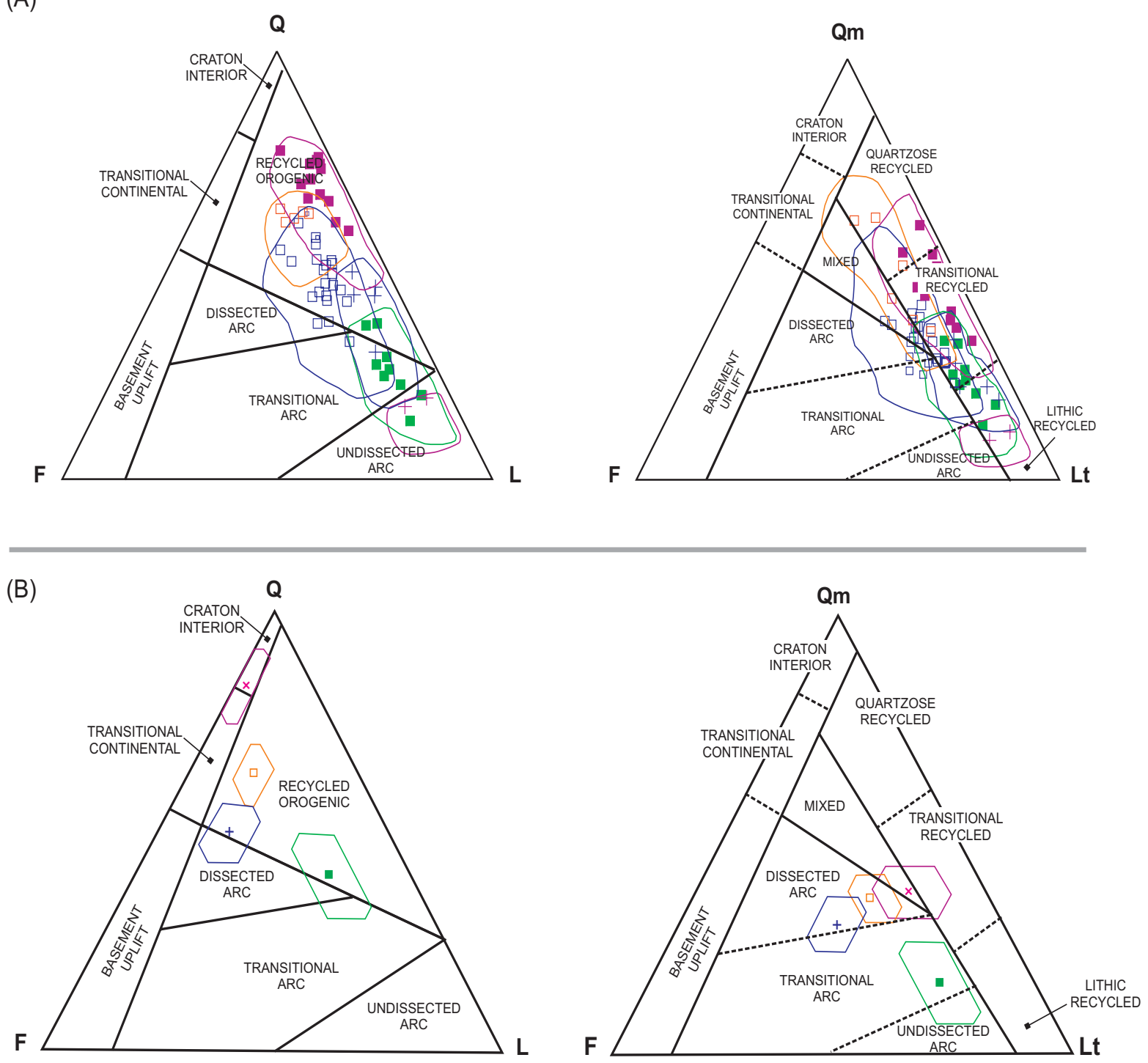

Figure 3. Tectonic provenance for Usibelli Group and Nenana Gravel sandstone clasts from this study (A) and Ridgway and others (1999; B). (A) Standard deviation error for this study is from Van Der Plas and Tobi (1965). Tectonic provenance diagrams are modified from Dickinson and others (1983). See table 2 for grain parameters not listed here. Parameters: $D=d e-$ trital minerals. Calculated parameters: $L=L v+L s+$ $L m+L p+D ; L t=Q p+L$. Parameter ' $L$ ' in this study includes detrital minerals, because some samples contain a significant amount of mica grains between 0.0625-2.0 mm in diameter. Amounts of other detrital minerals are negligible. See appendix $C$ for raw data. (B) Average modal compositions of Tertiary sandstone from Ridgway and others (1999). Polygons represent

\begin{tabular}{|c|c|}
\hline This study & Ridgway and others, 1999 \\
\hline$\square$ Nenana Gravel & $\square$ Nenana Gravel \\
\hline $\begin{array}{c}+ \text { + Lignite Creek 1 } \\
\square \text { Lignite Creek 2 }\end{array}$ & + Lignite Creek \\
\hline$\square$ Suntrana & $\square$ Suntrana \\
\hline \begin{tabular}{c}
\hline Healy Creek 1 \\
Healy Creek 2
\end{tabular} & $\times$ Healy Creek \\
\hline
\end{tabular}
one standard deviation about the means. Tectonic provenance diagrams are from Dickinson and others (1983). Grain parameters are as shown above except detrital minerals ' $D$ ' are not included in calculated parameters ' $L$ ' or ' $L t$ '. 
reported that bedding in the Nenana Gravel and the Lignite Creek Formation is almost parallel in the southern Fairbanks A-4 Quadrangle. Because, in this area, Lignite Creek contains up to 5 percent Cantwell Formation conglomerate and the compositions of Lignite Creek and Nenana Gravel are similar (figs. 2 and 3), we infer that the Nenana Gravel may be in paraconformable contact with the underlying Lignite Creek Formation. A portion of the Lignite Creek Formation may represent a mixing zone of sediment from the Yukon-Tanana terrane and Alaska Range, arriving from the east. A mixing zone in the Lignite Creek Formation would suggest that uplift of the Alaska Range started before the deposition of the Nenana Gravel in this section of the Alaska Range foothills. Wahrhaftig and others (1969) suggest a similar scenario for deposition of the Grubstake Formation, because it also contains clasts of Cantwell Formation and is lithologically more similar to the Nenana Gravel than the rest of the Usibelli Group.

Qualitative measurements of kaolinite and montmorillonite and tentative presence of chlorite in the clay fractions of Tertiary sedimentary rocks were compared with a similar study conducted in the Nenana coal basin along Lignite and Healy creeks (Triplehorn, 1976). Sixtyfive samples with a significant amount of fine-grained material were analyzed. The clay composition of the units

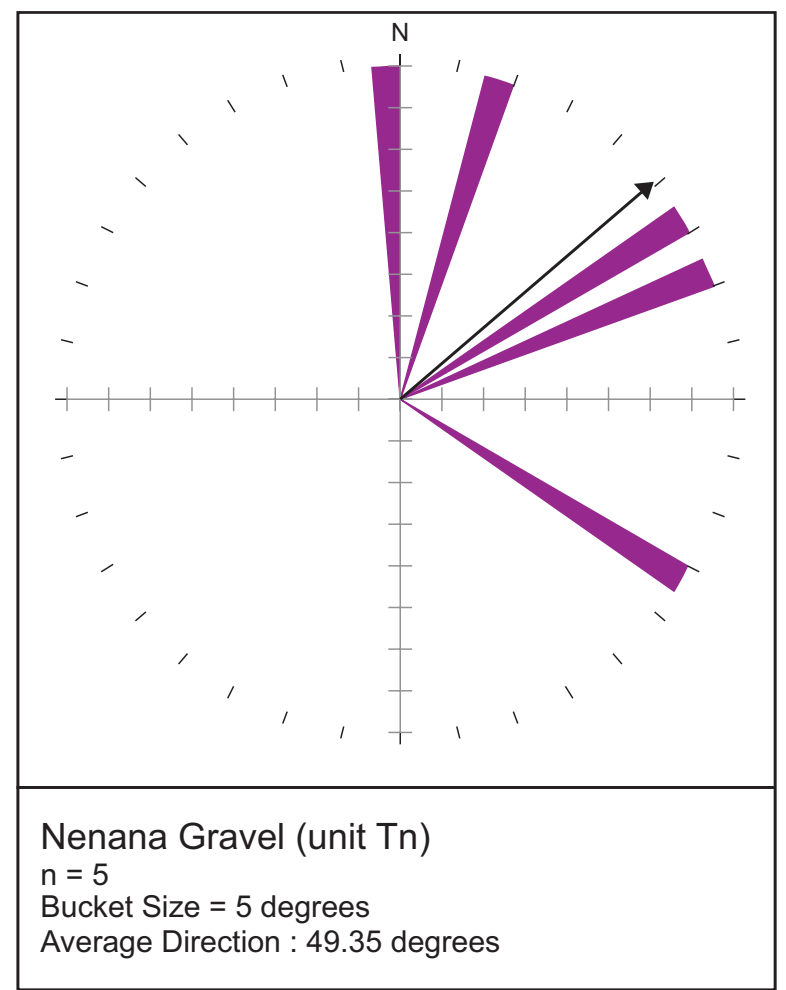

appears to be an effective geologic mapping tool in the Tertiary units. According to Triplehorn (1976), the Usibelli Group can essentially be divided into two sections based on its kaolinite and montmorillonite content (table 3). (No data are available for comparison with the Nenana Gravel samples from this study.) We find three groups of differing clay compositions that track closely with the clay percentages suggested by Triplehorn (1976; table 3; appendix D). Our data and data from Triplehorn (1976) indicate the Healy Creek Formation has the lowest montmorillonite content and that kaolinite content decreases up-section. Triplehorn (1976) suggests that montmorillonite is weathering from volcanic glass (possibly from ash, flows, or intrusions in the subsurface) and kaolinite is weathering from feldspar. The increase in montmorillonite composition up-section may indicate increasing contributions of a volcanic source area. In the map area, the prevalent, underlying arkosic metawacke would be an excellent source for the feldspar, and, hence, the kaolinite.

Fifteen samples were collected for palynology from random exposures in the Usibelli Group with no definite lithologic correlation between sites, except as assigned from geologic mapping and other data. Two hundred pollen grains were identified and counted per sample, and samples were also scanned for unusual grains or

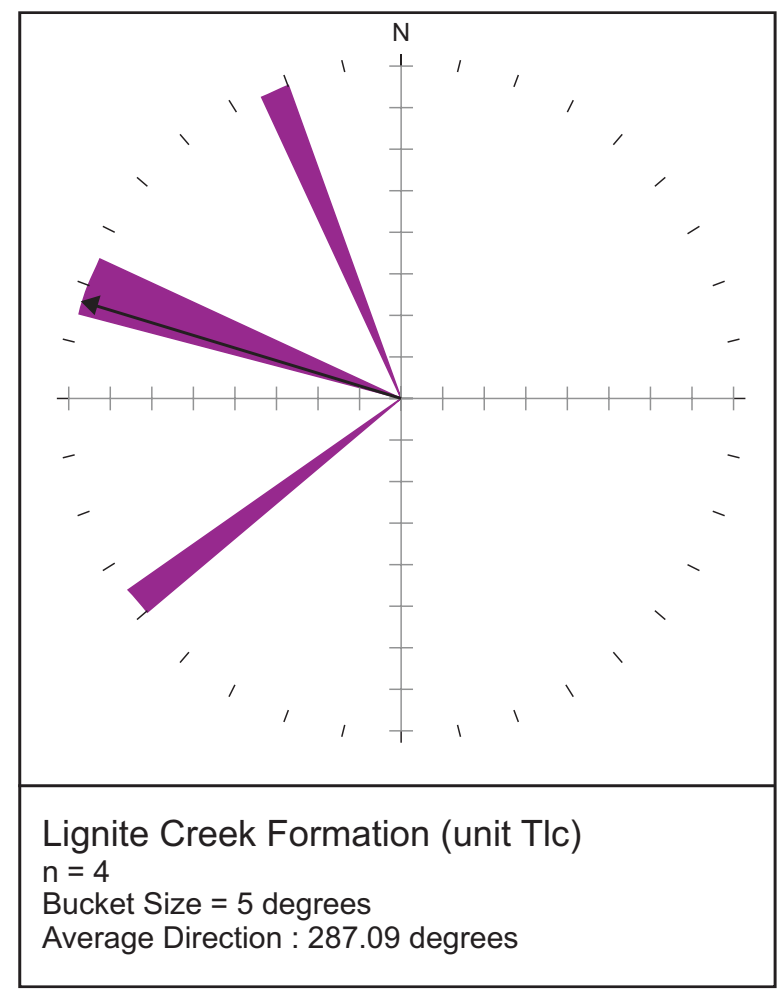

Figure 4. Paleocurrent directions measured from cross-beds in the Liberty Bell area. Note: $n=$ number of samples measured. 
Table 3. Qualitative comparison of montmorillonite and kaolinite content in Nenana Gravel and Usibelli Group clays. Data from this study and Triplehorn (1976). Very small, small, moderate, large, and very large refer to amounts of either montmorillonite or kaolinite in the sample. See appendix $D$ for compositional data from individual samples.

\begin{tabular}{l|ll|ll|l}
\hline \multicolumn{1}{c|}{ Unit } & \multicolumn{2}{|c|}{ Triplehorn (1976) } & \multicolumn{2}{c}{ This study } & \multicolumn{2}{c}{ This study } \\
& montmorillonite & kaolinite & montmorillonite & kaolinite & other mineral(s) \\
\hline Nenana Gravel & no data & no data & small to moderate & small to moderate & $\begin{array}{c}\text { possible chlorite } \\
\text { and zeolite }\end{array}$ \\
Lignite Creek Fm. & $\begin{array}{l}\text { moderate to } \\
\text { large }\end{array}$ & $\begin{array}{l}\text { moderate to } \\
\text { large }\end{array}$ & small to moderate & small to moderate & $\begin{array}{l}\text { possible chlorite } \\
\text { and zeolite }\end{array}$ \\
Suntrana Fm. & $\begin{array}{l}\text { moderate to } \\
\text { large }\end{array}$ & $\begin{array}{l}\text { moderate to } \\
\text { large }\end{array}$ & small to moderate & $\begin{array}{l}\text { moderate to } \\
\text { very large }\end{array}$ & possible chlorite \\
Sanctuary Fm. & small & very large & no data & no data & no data \\
Healy Creek Fm. & none to small & very large & none to small & $\begin{array}{l}\text { moderate to } \\
\text { very large }\end{array}$ & $\begin{array}{l}\text { more possible } \\
\text { chlorite }\end{array}$ \\
\hline
\end{tabular}

Table 4. Pollen samples from random outcrop locations in the Tertiary Usibelli Group. Samples of fine-grained sedimentary rock and coal were collected. Samples are arranged in pseudo-stratigraphic order. The vertical organization of samples is primarily based on comparison with taxa of samples collected from the Usibelli Group and their inferred climatic conditions (Wahrhaftig and others, 1969; Leopold and Liu, 1994). Samples were adjusted in the pseudo-section according to their spatial locations within formations and comparison of their flora. See appendix E for raw data and taxa included in each summarized category.

\begin{tabular}{|c|c|c|c|c|c|c|c|c|c|c|c|c|c|c|}
\hline $\begin{array}{c}\text { Map } \\
\text { Location }\end{array}$ & Unit & $\begin{array}{l}\text { Climate } \\
\text { Inferred }\end{array}$ & Sample Number & 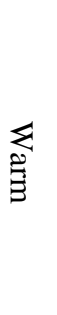 & $\begin{array}{l}\Omega \\
0 \\
0\end{array}$ & 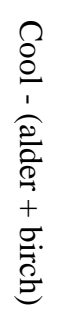 & $\sum_{0}$ & 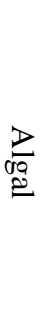 & $\begin{array}{l}\text { T) } \\
\stackrel{D}{\exists} \\
\end{array}$ & 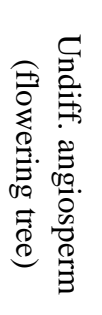 & 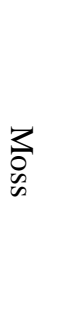 & 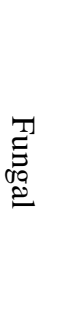 & 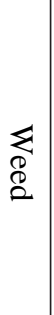 & 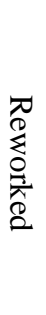 \\
\hline P1 & Lignite Creek Fm. & cool & 2005JEA160C & 9 & 182 & 175 & 1 & 0 & 3 & 5 & 1 & 0 & 1 & 0 \\
\hline $\mathrm{P} 2$ & Lignite Creek Fm. & warm & 2005JEA237A & 32 & 111 & 63 & 5 & 4 & 47 & 1 & 3 & 0 & 1 & 0 \\
\hline P3 & Suntrana Fm. & moderate & 2005MBW415A & 14 & 162 & 82 & 6 & 0 & 1 & 15 & 7 & 1 & 0 & 1 \\
\hline P4 & Suntrana Fm. & moderate & 2005Z235A & 0 & 153 & 100 & 39 & 0 & 0 & 5 & 42 & 0 & 0 & 0 \\
\hline P5 & Suntrana Fm. & moderate & 2005Z165B & 7 & 161 & 75 & 1 & 0 & 26 & 2 & 4 & 1 & 0 & 0 \\
\hline P6 & Suntrana Fm. & moderate & 2005Z171B & 18 & 106 & 81 & 2 & 0 & 70 & 1 & 5 & 0 & 0 & 1 \\
\hline P7 & Healy Creek Fm. & cool & 2005LF124A & 11 & 174 & 122 & 1 & 0 & 5 & 3 & 7 & 0 & 0 & 0 \\
\hline P8 & Healy Creek Fm. & cool & 2005Z47B & 9 & 189 & 182 & 1 & 0 & 2 & 0 & 1 & 0 & 0 & 0 \\
\hline P9 & Healy Creek Fm. & cool & 2005MBW232A & 2 & 177 & 145 & 2 & 1 & 14 & 3 & 3 & 1 & 0 & 0 \\
\hline P10 & Healy Creek Fm. & moderate & 2005MBW144A & 8 & 168 & 40 & 6 & 0 & 10 & 7 & 7 & 0 & 0 & 0 \\
\hline P11 & Healy Creek Fm. & warm & 2005JEA210C & 38 & 134 & 113 & 5 & 2 & 17 & 3 & 3 & 2 & 0 & 1 \\
\hline P12 & Healy Creek Fm. & warm & 2005LF105A & 53 & 121 & 82 & 7 & 0 & 18 & 1 & 8 & 0 & 0 & 0 \\
\hline P13 & Healy Creek Fm. & warm & 2005Z36C & 98 & 67 & 14 & 3 & 2 & 6 & 26 & 2 & 0 & 0 & 0 \\
\hline P14 & Healy Creek Fm. & unknown & 2005LF217D & 1 & 0 & 0 & 0 & 0 & 2 & 0 & 0 & 0 & 0 & 0 \\
\hline P15 & Healy Creek Fm. & unknown & 2005Z229A & 0 & 0 & 0 & 0 & 0 & 8 & 0 & 0 & 0 & 0 & 0 \\
\hline
\end{tabular}


flora not represented in the official count. Pollen grains are well preserved and thermally immature. Three samples did not contain enough pollen for a complete count; two samples were essentially barren, but one sample contained 76 grains and was included in the calculations. In order to arrange the samples within the pseudo-section, pollen counts were normalized to 200 , pollen with climatic and environmental significance were summarized, and samples were visually compared to each other and data from Leopold and Liu (1994; table 4). Climatic conditions in the Miocene were variable (Leopold and Liu, 1994; Ridgway and others, 1999), and all of the flora indicated from pollen in the samples existed throughout the Miocene (R.L. Ravn, written commun., 2006). In the absence of a comparative vertical succession of palynological data, the data from these samples cannot be presently used as a tool for geologic mapping. In conjunction with other data, the flora do suggest climatic conditions related to temperature or topography and environmental conditions such as wet swamp versus dry deciduous forest.

Lower Healy Creek Formation is characterized by pollen from thermophilous tree taxa of a mixed deciduous-conifer forest, and pollen from upper Healy Creek Formation suggests a cooler climate (Leopold and Liu, 1994). Wahrhaftig and others (1969) noted Late Oligocene (later reinterpreted to be Early Oligocene; Leopold and Liu, 1994) exotic pollen taxa Eucommia, Engelhardtia type, Gynkaletes, and Orbiculapollis in a sample from lower Healy Creek Formation near the junction of Rex and California creeks. Wolfe and Tanai (1987) extend the age of the Rex Creek samples into the Late Eocene. Pollen grains from these older taxa, however, were not seen in any samples from this study. Instead, our samples from the Healy Creek Formation contain pollen from a variety of warm- (including tropical fern Osmunda) and cool-loving (including pine, spruce, and juniper) flora, and these samples are arranged in the pseudo-section from warm-loving to cool-loving progressively up-section. A pollen assemblage primarily of thermophiles and lesser conifers indicates the Suntrana Formation was deposited in a warm environment (Leopold and Liu, 1994). Each of our Suntrana Formation samples contain a mixture of pollen from warm- and cool-loving flora, which suggests a temperate climate for this unit. Although the Lignite Creek Formation is characterized by cool-loving flora (Leopold and Liu, 1994), high counts of elm pollen from one Lignite Creek sample suggest a warmer climate. The sample was probably collected from lower in the section. High counts of pine, juniper, and spruce pollen from a sample probably collected higher in the section indicate a cool climate.

\section{PALEOZOIC UNITS}

Wahrhaftig (1968, 1970a-f) mapped greenschist-facies meta-igneous and metasedimentary rocks in the region and assigned them to the Totatlanika Schist and Keevy Peak Formation. Wahrhaftig described the Totatlanika Schist as being dominantly of volcanic origin and the Keevy Peak Formation as being dominantly of sedimentary origin, although each unit contains a variety of rock types. These two units crop out in the map area and unconformably underlie Quaternary and Tertiary strata. U-Pb SHRIMP zircon data indicate the two formations are Late Devonian to Early Mississippian in age (fig. 5; Dusel-Bacon and others, 2004). A white-mica sample from the lower Totatlanika Schist, sampled as far away as possible from any observed intrusions, exhibited an ${ }^{40} \mathrm{Ar} /{ }^{39} \mathrm{Ar}$ plateau age of 152.8 $\pm 1.0 \mathrm{Ma}$ (map location A6; table 5). This age presumably approximates the age of the latest regional metamorphism. The Keevy Peak Formation and the five members of the Totatlanika Schist are arranged below in the stratigraphic order proposed by Wahrhaftig (1968). Previously mapped lithologies and their interpreted protoliths are from Wahrhaftig (1968) unless otherwise referenced.

\section{TOTATLANIKA SchisT}

Sheep Creek Member-Thinly bedded dark gray and light gray slate. Quartz-feldspar-sericite schist with preserved bedding and crossbedding (meta-arkose). Purple and pale green slates composed of chlorite, sericite, epidote, and minor quartz (tuffaceous protolith). Fine-grained graphitic schist with 60 percent quartz and 40 percent graphite. Banded chert (Wahrhaftig, 1970d). Lenticular bodies of rhyolite schist (shallow, sill-like intrusions) occur within Mystic Creek and Sheep Creek Members.

Mystic Creek Member-Fine-grained purple, green, and yellow (and black [graphitic?]; Wahrhaftig, 1970a, 1970d) schist with 10-20 percent relict phenocrysts of beta-quartz, albite, and orthoclase in a fine-grained foliated matrix of quartz, feldspar, sericite, chlorite, hematite, and stilpnomelane (metarhyolite). Thin fossiliferous limestone beds.

Chute Creek Member-Dark green chlorite-zoisite (or epidote)-actinolite-albite-biotite schist with rare relict pyroxene and plagioclase (greenschist facies, metamorphosed mafic volcanic rocks).

California Creek Member-White- to buff-weathering, gray quartz-orthoclase-sericite schist and gneiss, with mixed coarse- and medium-grained phases. Coarse-grained facies contains 2.5 to 25 
mm K-feldspar augen and smaller quartz in gray to greenish-gray matrix of sericite, chlorite, quartz, feldspar, and calcite. Euhedral to broken anhedral augen. Medium-grained facies contains flattened to sharply angular quartz < feldspar (orthoclase and albite) grains up to $2 \mathrm{~mm}$ in diameter in a foliated groundmass of sericite, orthoclase, and quartz. Interpreted as felsic meta-igneous rocks (Gilbert and Bundtzen, 1979). Includes thin, interbedded layers of black carbonaceous schist and slate. (Present in map area.)

Moose Creek Member-Black graphitic schist, dark green chloritic schist (metavolcanic), and yellow quartz-orthoclase schist and gneiss. Unit is lenticular and tectonically disturbed. (Present in map area.)

\section{Keevy Peak Formation}

Located stratigraphically below the Totatlanika Schist. Unit contains gray-green-purple slate, quartz-sericite schist, graphitic schist, graphitic quartzite, calcareous schist, quartz-feldspar metawacke ("grit”), and stretched conglomerate. The Keevy Peak Formation is located unconformably on the Healy Schist (Birch Creek Schist of former usage; Wahrhaftig, 1968; Newberry and others, 1997).
Wahrhaftig (1970c) mapped the lower two members, Moose Creek and California Creek, in the Liberty Bell map area. He described the lower member (Moose Creek) as primarily containing yellow quartz-orthoclase schist and gneiss in contrast to the aerially extensive and stratigraphically younger California Creek Member, which hosts the Liberty Bell gold deposit and contains gray quartz-orthoclase-sericite schist and gneiss (Wahrhaftig, 1970c). Wahrhaftig considered the contact between the members as unconformable. Both units have been suggested to have a crystal-rich pyroclastic (felsic igneous) protolith (Capps, 1912; Wahrhaftig, 1968; Gilbert and Bundtzen, 1979). Instead, our mapping shows that the bulk of the California Creek Member is of sedimentary origin (unit Daw), instead of igneous origin, and was intruded by plugs, dikes, sills, and possibly flows of now-metamorphosed granite (unit Dg) and rhyolite (and rare dacite; units Dr and Dar). Conversely, the Moose Creek Member does have an igneous protolith but likely represents a larger, metamorphosed granite body identical to the ones intruding the California Creek Member. Further discussion of the Moose Creek Member is located below.

The metasedimentary and meta-igneous rocks appear similar in outcrop. A combination of chemical data (major- and minor-oxide and trace elements), modal petrographic data, and textural observations made on hand

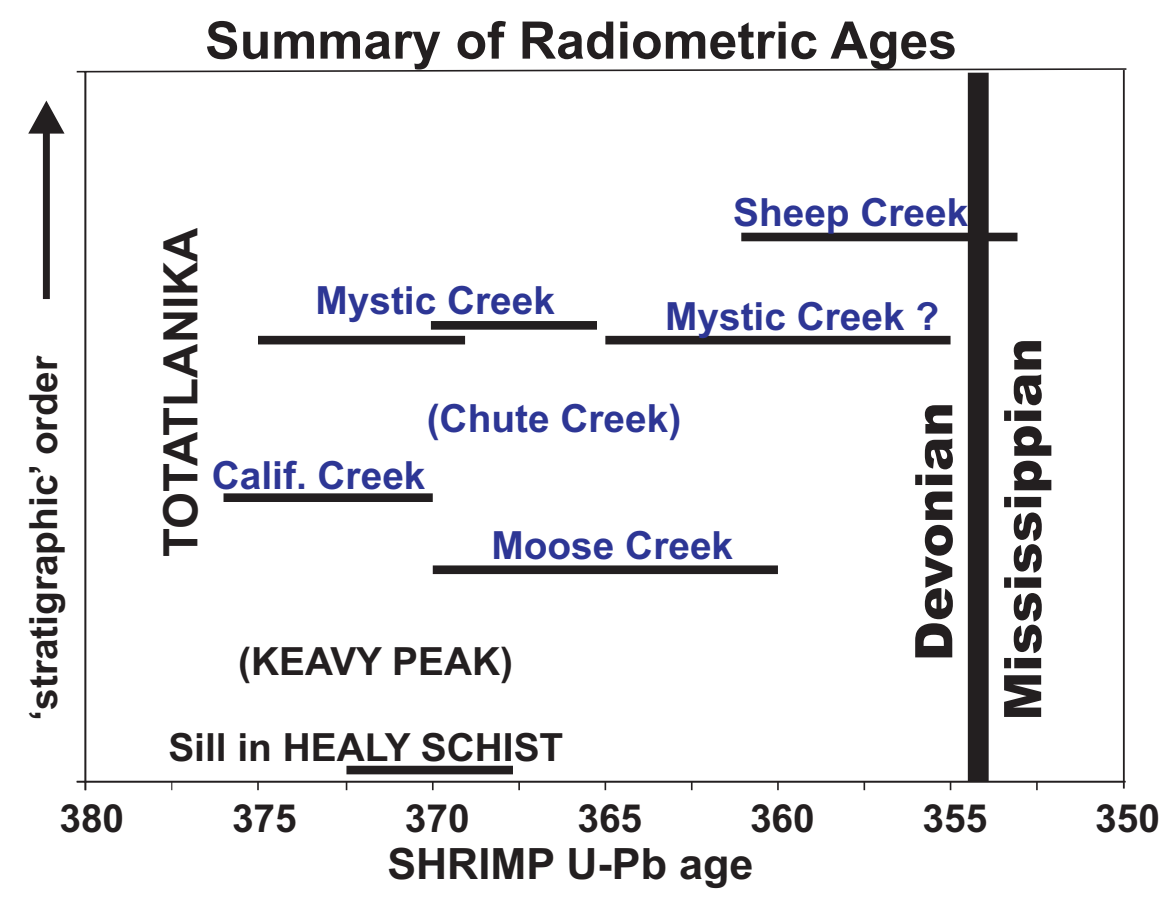

Figure 5. Summary of SHRIMP U-Pb ages from Paleozoic rocks collected in the Alaska Range Foothills. Age data from Dusel-Bacon and others (2004). 


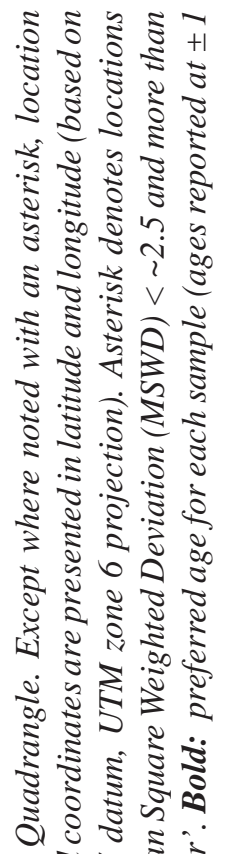

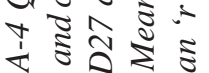

\%

政

会

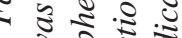

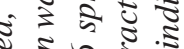

ธิ

จ

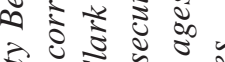

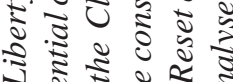

政

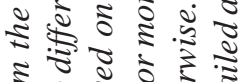

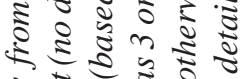

跣

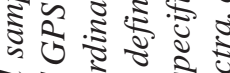

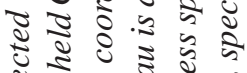

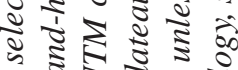

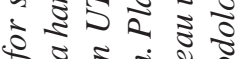

ข

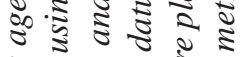

는

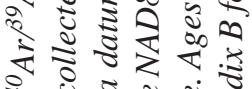

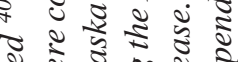

ปั้

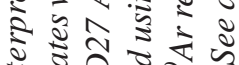

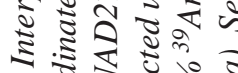

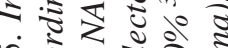

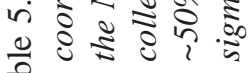

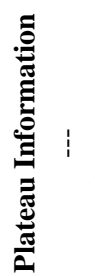

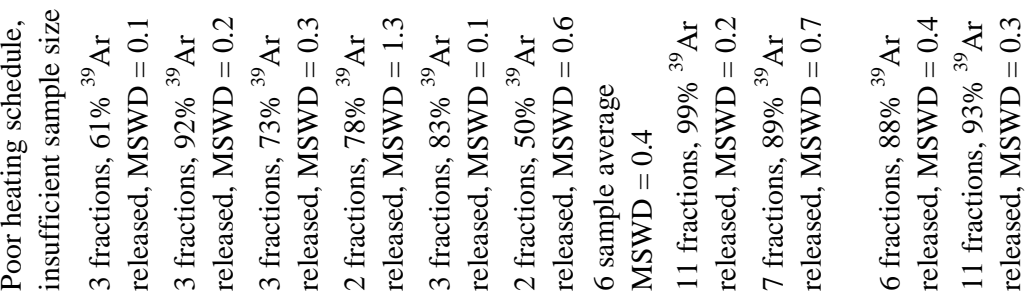

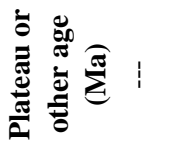

+1

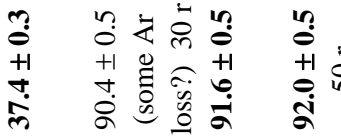

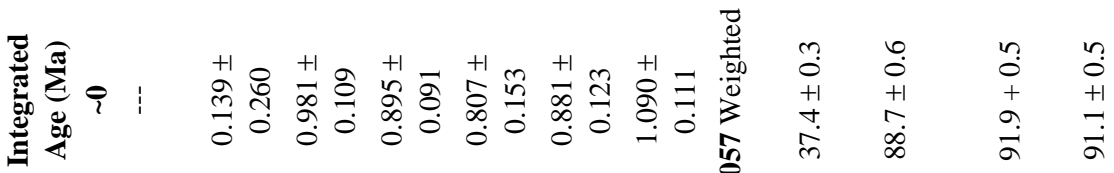

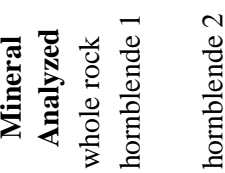

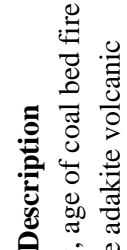

ते है

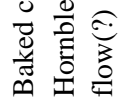

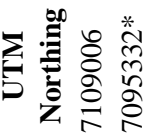

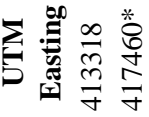

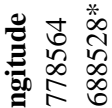

宁

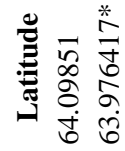

究

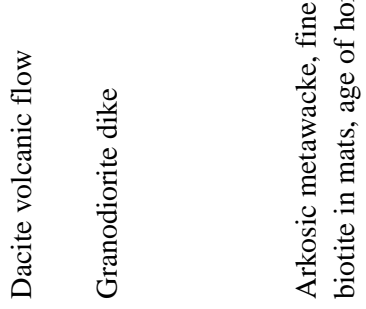

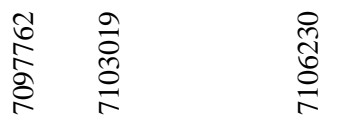

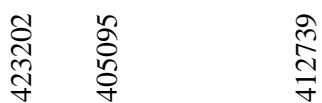

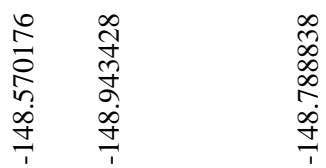

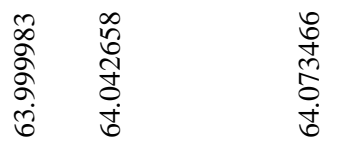

द द य

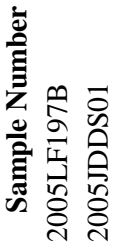

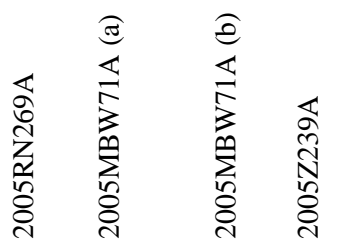




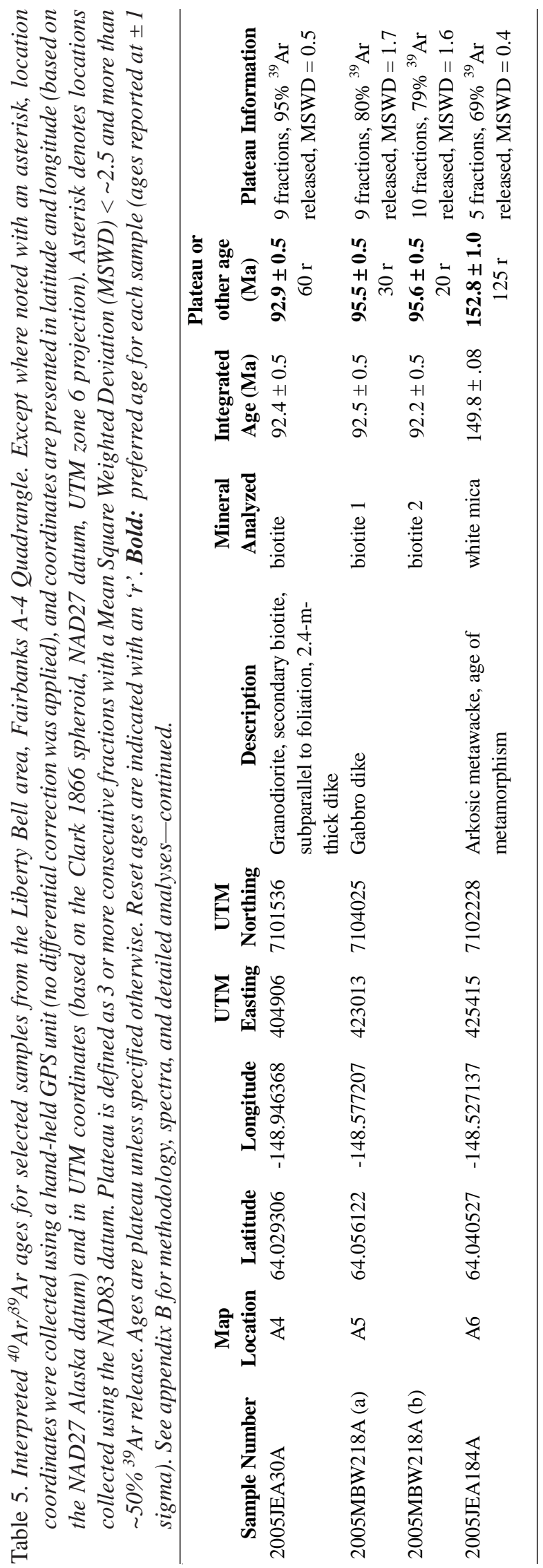


samples and thin sections are necessary to differentiate these rocks. The best discriminant is $\mathrm{Nb}+\mathrm{Y}$ (fig. 6). Meta-igneous rocks typically contain $\mathrm{Nb}+\mathrm{Y}>50$ ppm; metasedimentary rocks typically contain $\mathrm{Nb}+\mathrm{Y}<50$ ppm. Alteration is a complicating factor in the Liberty Bell Mine area. Altered samples commonly contain elevated $\mathrm{SiO}_{2}$, which may dilute the trace-element content of the rocks. Samples containing 40-60 ppm Nb + Y are differentiated based on other chemistry, texture, and modal composition. Meta-igneous rocks tend to be more massive and less well foliated because they contain less mica. Relict quartz and feldspar phenocrysts are randomly scattered throughout the sample, and are usually euhedral to subhedral. The ratio of feldspar to quartz crystals is 3:2 to 2:1. Quartz crystals are frequently embayed; this texture is less common in the metasedimentary rocks. Meta-igneous rocks tend to have lower $\mathrm{TiO}_{2}$ contents than the metasedimentary rocks. In metasedimentary rocks, relict textures such as graded bedding and grain sorting are common in hand sample and in outcrop. Metasedimentary rocks may contain sedimentary and igneous lithic fragments, and a variety of quartz types, including white, smoky, and clear quartz. Quartz and feldspar clasts are more rounded than euhedral.
Within the metasedimentary unit Daw described above, we recognize metamorphosed arkosic wacke, and minor feldspathic and quartz wacke. The presence of euhedral grains suggests the sediments have not undergone significant traction transport (D.L. LePain, oral commun., 2006). The presence of more than a thousand meters of graphitic quartzite and graphitic schist interbedded with the Devonian section (Warhaftig, 1968) suggests the rocks were deposited in a subaqueous environment. Due to the homogeneous composition (quartz + feldspar) of unit Daw and presence of occasional euhedral and embayed crystals, it is probably sourced in felsic igneous rocks and may be volcaniclastic. Primary textures of volcaniclastic grains could be retained for a long distance (tens to hundreds of $\mathrm{km}$ ) if transported in a subaqueous environment (K.F. Bull, oral commun., 2006). Future study of the Paleozoic rocks would include additional dating of metasedimentary and meta-igneous rocks.

The Keevy Peak Formation contains graphitic quartzite (unit Dgq) and phyllitic, metamorphosed quartz wacke and minor feldspathic wacke and quartz arenite (unit Dqw). Locally exposed, thinly bedded, cyclic, sizegraded meta-arenite-phyllitic metawacke layers suggest in part a deep-water, turbidite origin. For units Dqw and

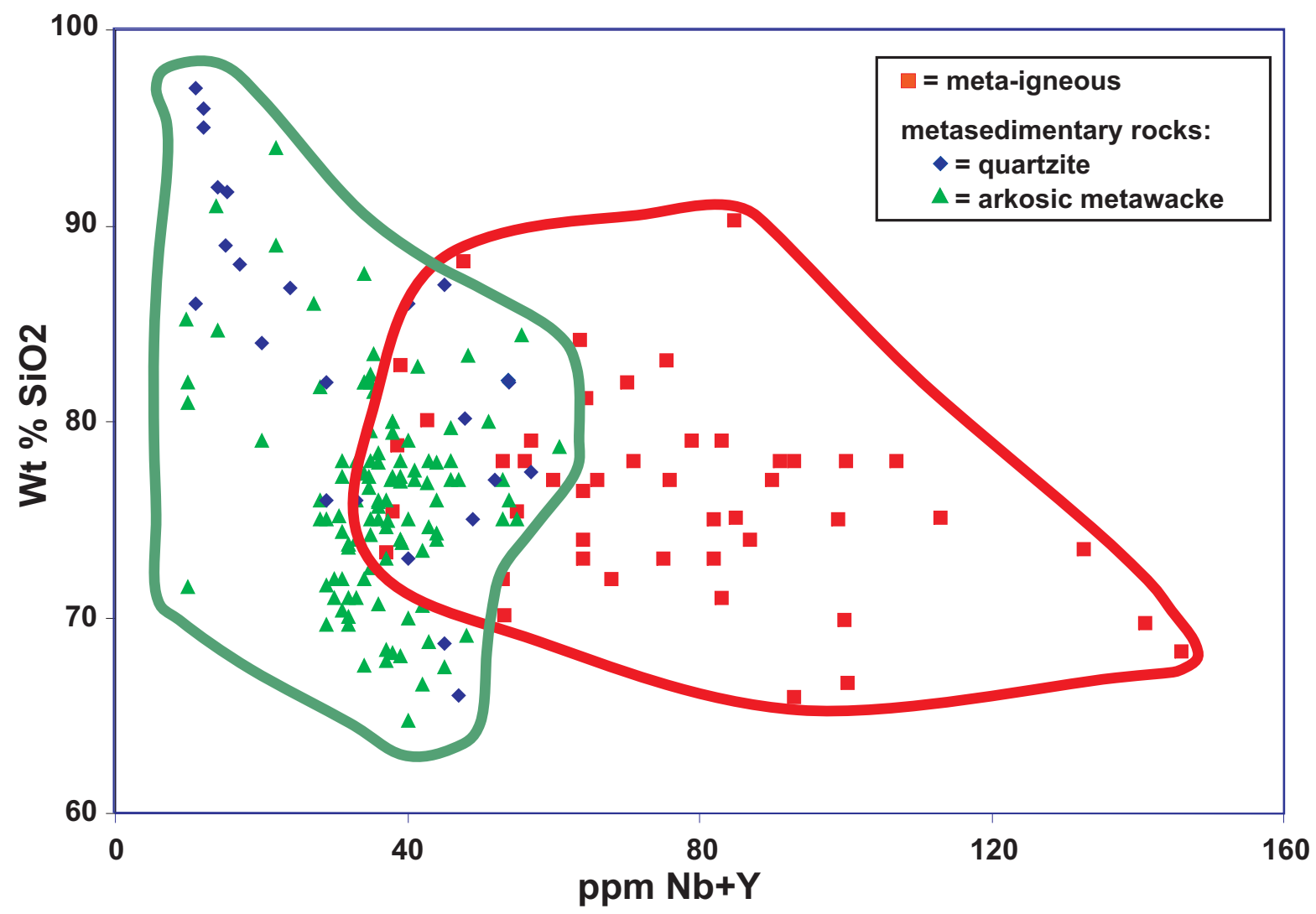

Figure 6. Discriminant analysis of metasedimentary and meta-igneous rocks from the Liberty Bell area. Data from this study (appendix A) and Athey and others (2005). 
Daw, definitions of wacke (or "grit" in the Keevy Peak Formation in Wahrhaftig [1968]) and arenite are modified from Williams and others (1982) and Pettijohn and others (1987). Sandstone with $>15$ percent matrix of clay and fine silt is defined as wacke, and sandstone containing $<15$ percent matrix is arenite. Sandstone with $<10$ percent detrital feldspar grains in which quartz is the dominant detrital grain is referred to as quartz arenite or quartz wacke, depending on the abundance of detrital silt and clay. Wacke with $>10$ and $<25$ percent feldspar is referred to as feldspathic wacke; if detrital feldspar component is $>25$ percent, the rock is called an arkosic wacke.

Shallowly emplaced and (or) extrusive meta-igneous rocks are located throughout the map area. Textures range from an aphyric metarhyolite (flow?; unit Dar) at the head of Spruce and Cody creeks to fine- and medium-grained porphyritic metarhyolite (unit Dr) to megacrystic metagranite with potassium feldspar crystals $3 \mathrm{~cm}$ in length along the northern edge of the map (unit Dg). Chemical and textural data indicate that the metagranite and metarhyolite bodies intruding the California Creek Member are indistinguishable from the rocks mapped as Moose Creek Member schist and gneiss by Wahrhaftig (1970c). We interpret the variable thickness of the Moose Creek Member (Wahrhaftig, 1968) as a result of its igneous nature, and suggest that the remaining Moose Creek lithologies, mafic metavolcanic schist and graphitic schist (Wahrhaftig, 1968), be reassigned to the California Creek Member and Keevy Peak Formation, respectively.

In contrast, we have identified a group of mixed lithologies, historically mapped as a part of the California Creek Member (Wahrhaftig, 1970c), that appear to have stratigraphic significance. This group, consisting of metarhyolite (unit Dr), metagranite (unit Dg), metabasite (unit $\mathrm{Db}$ ), fine-grained quartzite (unit Dq), and graphitic quartzite (Dgq), is interfoliated in no particular order within the topographically (and stratigraphically?) lower section of the arkosic metawacke (unit Daw). The group is approximately 100$200 \mathrm{~m}$ thick and traceable across the area for at least 25 $\mathrm{km}$. This group is equivalent to the "Liberty Bell Mine sequence" of Freeman and others (1987). Due to the abnormally high carbonate content in altered metabasite (unit $\mathrm{Db}$ ), this group is the preferred ore host in the Liberty Bell area.

The combination of mostly felsic (units Dr, Dg, and Dar) and occasionally mafic (unit Db) lithologies indicates an ancient, bimodal volcanic system. These units display within-plate trace-element compositions (fig. 7). The bimodal chemistry, elevated concentration of highfield-strength and rare-earth elements, and presence of carbon-rich basinal sediments suggest that these rocks formed in an extensional tectonic setting such as a rift environment like those in the Red Sea and Gulf of California (this study, Dusel-Bacon and others, 2004). Volcanogenic massive sulfide (VMS) deposits are associated with deep-water structures such as submarine caldera and rift zones, and both the Totatlanika Schist and Keevy Peak Formation host VMS occurrences (commonly containing galena + sphalerite \pm chalcopyrite \pm pyrite in the Alaska Range foothills; Newberry and others, 1997). Because the meta-igneous and meta-sedimentary "Liberty Bell Mine sequence" (Freeman and others, 1987) only contains anomalous metals where hornfelsed in the Liberty Bell Mine area, mineralization at the Liberty Bell Mine is likely pluton-related and not associated with VMS.

No stratabound base-metal sulfide occurrences were located in the California Creek Member, Moose Creek Member, or Keevy Peak Formation during the recent mapping project. The closest VMS occurrence is located about $11 \mathrm{~km}$ southeast of the map area (Freeman and Schaefer, 2001; Ellis and others, 2004) in the Keevy Peak Formation (Wahrhaftig, 1970e). The most notable VMS prospects in the Bonnifield mining district, Red Mountain/Dry Creek and WTF, are hosted within the uppermost section of the Totatlanika Schist, Mystic Creek, and Sheep Creek members, respectively (Newberry and others, 1997). The geotectonic paleoenvironment of the lower members of the Totatlanika Schist may have been incompatible with the development of VMS mineralization. The Keevy Peak Formation and oldest members of the Totatlanika Schist can be interpreted as sedimentary deposits formed during an early stage of rift basin development and beginning or peripheral stage of more extensive volcanism. Keevy Peak graphitic quartzite (unit Dgq) may represent the deepening of the basin with occasional influx of quartz-rich sediment (unit Dqw). Carbonate alteration of basalts (unit $\mathrm{Db}$ ) from heated saline water not long after emplacement would be consistent with an extensional setting. The rift basin in its early stage could either be marine or saline lake, but a corral fossil Syringopora collected in marble from the Mystic Creek Member (located stratigraphically up-section; Wahrhaftig, 1968) indicates the basin was marine by the time that member was deposited. Greater but intermittent amounts of limestone were deposited in the Mystic Creek Member sediments (Wahrhaftig, 1968), suggesting an increase in heat, and by extension, in volcanism. (Heating marine water can decrease the solubility of calcite; heat from volcanic activity could allow limestone deposition at significant water depth.) Bimodal volcanic rocks do appear in greater amounts higher in the stratigraphic section. The Chute Creek Member, located stratigraphically above the California Creek Member, contains metamorphosed mafic volcanic rocks, and the two youngest members, Sheep Creek and Mystic Creek, 
contain rocks possibly of felsic volcanic origin (Wahrhaftig, 1968). The absence of volcanogenic massive sulfide prospects in the lower portion of the Totatlanika Schist may be a result of the scarcity of volcanic rocks; the center of the ancient volcanic system was possibly tens to hundreds of kilometers away, and (or) it occurred later (higher in the stratigraphic section).

\section{STRUCTURE}

Seismic activity related to movement on the Denali Fault and the poorly understood Northern Foothills thrust (informal name; Thoms, 2000; Ridgway and others, 2002; Bemis, 2004) is hazardous to important Alaskan infrastructure traversing the Alaska Range foothills, and national defense facilities located nearby. One of the objectives of DGGS's Liberty Bell project was to collect data that could help provide a better understanding of the regional tectonic framework. In the Liberty Bell area, a complex system of dormant and active faults and folds displaces the geologic units and mineralization. At least four episodes of structural deformation (Freeman and others, 1987) are present in the Liberty Bell area. Poor exposures, especially in poorly consolidated Tertiary formations, hampered the identification of faults in the field. Through the interpretation of linear features in electromagnetic and magnetic geophysical data (Burns and others, 2002) and aerial photography, in conjunction with detailed surficial and bedrock mapping, we recognize three sets of high-angle faults (northwest-, northeast-, and east-west-trending) and area-wide folding with axes primarily directed east-west. Faults were inferred where differing lithologies formed a contact relationship that could not be more simply explained by folding or normal intrusive or stratigraphic relations. Faults were also inferred from areas of intense silicification, clay gouge zones, and geomorphologic features such as boggy swales and linear drainages.

There are several reports of recent faulting in the map area. Freeman and others (1987) reported fractures in Quaternary alluvial bench sediments along Eva Creek. A possible scarp was located on a Paleozoic/Tertiary fault just south of hill VABM Coal (this study). An unsuccessful attempt to physically locate a possible fault scarp crossing pediment gravel (identified from aerial photography) was made by D.S.P. Stevens (oral commun., 2005). Recent regional studies suggest that the northern Alaska Range foothills are actively undergoing compression, resulting in a wedge-shaped fold and thrust fault belt propagating north from the Alaska Range (Thoms, 2000; Ridgway and others, 2002; Bemis, 2004). Previous to this study, data from the Liberty Bell area utilized in regional studies have primarily involved interpretation of aerial photography and Wahrhaftig's (1970c) mapping. Our ground-truth geologic mapping found no evidence of thrust faults. If present, the nearsurface expression of a basement-involved, regional structural system may be either active in conjunction with, superimposed on, or possibly reactivating highangle faults. Wahrhaftig (1970c) mapped a thrust fault that defined the contact between California Creek Member and "Moose Creek Member." Due to reinterpretation of the Devonian units presented in this report, this fault is relocated to the south and redefined as highangle. The extension of Wahrhaftig's (1970c) thrust fault and another postulated thrust fault located just north of hill VABM Coal (Bemis, 2004) primarily run along the unconformity between Devonian arkosic metawacke (unit Daw) and the Healy Creek Formation (unit Thc). At the location of the postulated thrust north of hill VABM Coal and on the eastern edge of the map, Freeman and others (1987) noted a fault dipping $50^{\circ}$ to the south in a trench. The fault is described as a 2-meterwide gouge zone composed of clay and crushed unit Daw. Offset was not determined as identical lithologies were juxtaposed by the fault.

Young folding, however, is documented in the map area. East-west-trending folds involving the Tertiary sedimentary rocks are common. Some of the anticline and syncline pairs may be parasitic folds indicating larger, regional structures. Freeman and others (1987) noted large-scale, east-northeast-trending, commonly asymmetrical folds plunging $10^{\circ}$ to the west, and state that Eva Creek flows down the axis of one of these synclines. Regionally, Wahrhaftig (1987) noted that the Nenana Gravel was deformed into irregular box folds with amplitudes of $0.6-1.8 \mathrm{~km}$ and wavelengths of 8-16 $\mathrm{km}$. Our cross-section shows where we interpret these major structures to cross the map area.

In the Liberty Bell Mine area, foliation and bedding measurements indicate a dome-like structure that is truncated by the Eva Creek fault (informal name) on its north side. There are several possible ways (and combinations of ways) this dome-like structure could have formed. Due to lack of surface and subsurface data, we can only speculate on the correct model. (1) Dome-like

Figure 7 (right). Tectonic setting for igneous and metaigneous rocks from the Liberty Bell area as indicated by trace-element discrimination diagrams. (A) Mafic igneous and meta-igneous rocks from the Liberty Bell area plotted on $\mathrm{Nb}-\mathrm{Zr}-\mathrm{Y}$ discrimination diagram for basalts. Diagram after Meschede (1986). (B) Felsic igneous and meta-igneous rocks from the Liberty Bell area plotted on $\mathrm{Rb}$ vs. $\mathrm{Nb}+\mathrm{Y}$ discrimination diagram for rhyolites. Diagram after Pearce and others (1984). Note: $W P=$ within-plate, $M O R B=$ mid-ocean ridge basalt, $E-M O R B=$ extensional, midocean ridge basalt. 
(A)

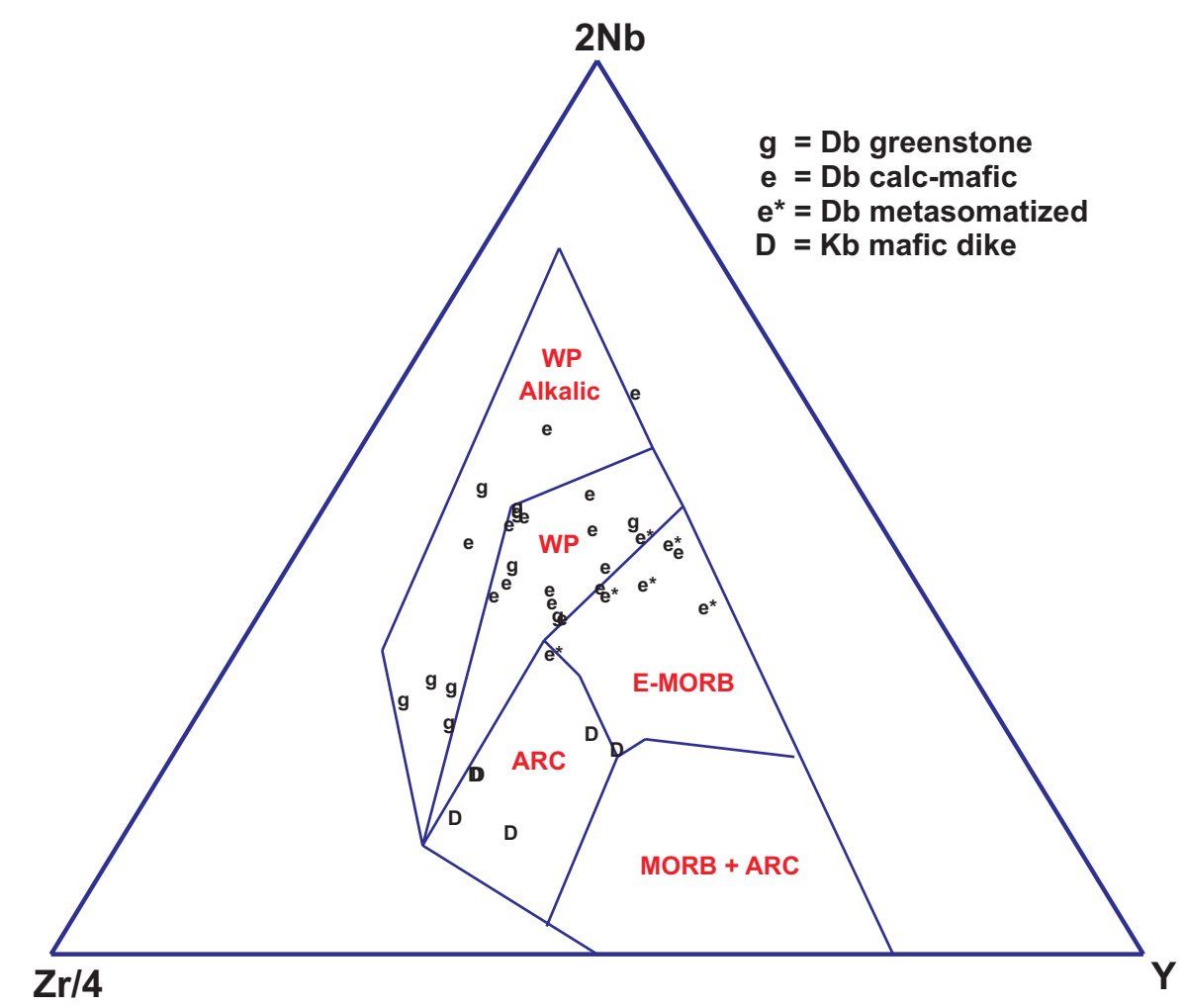

(B)

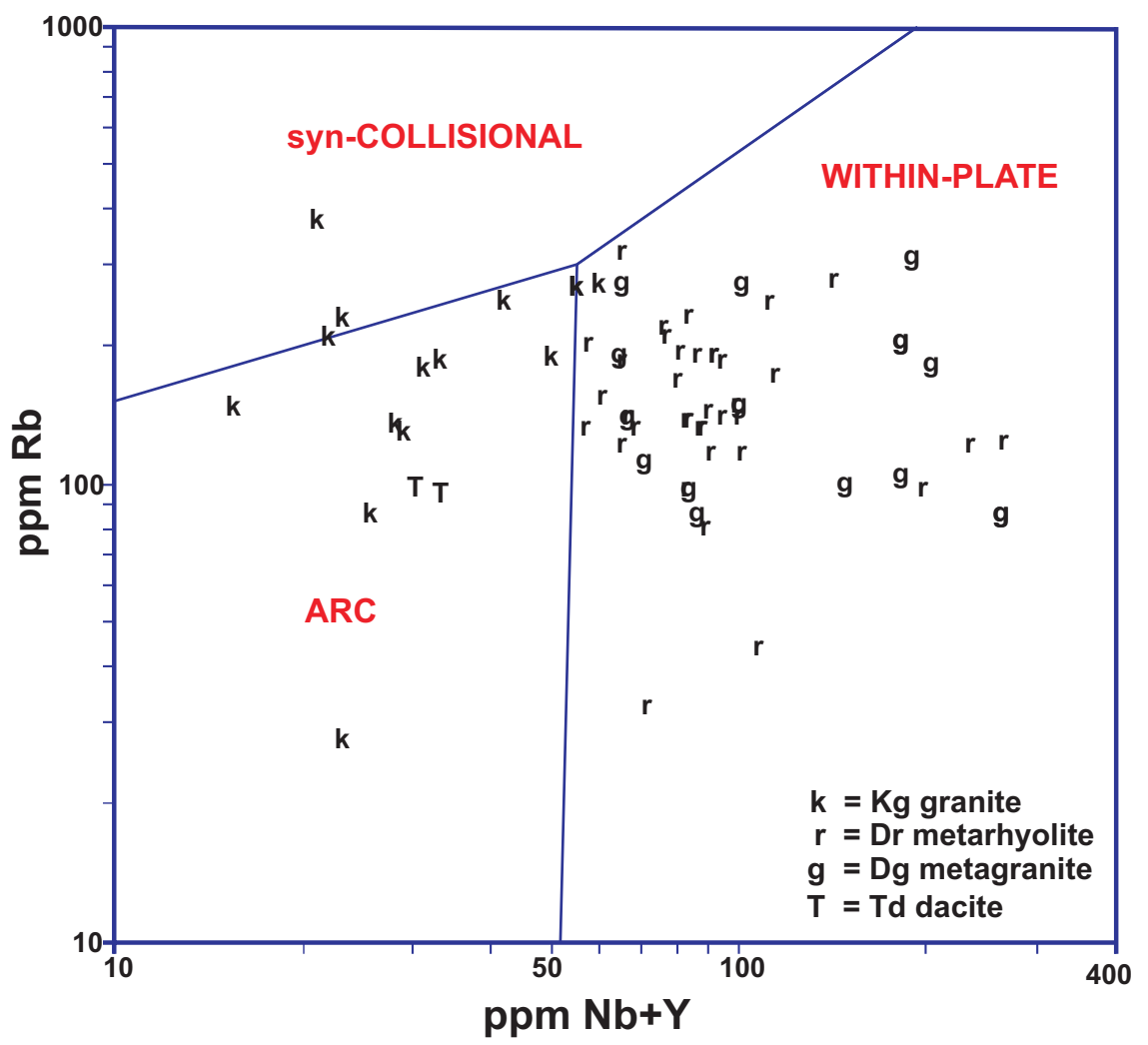


structure is related to regional folding caused by compression of Devonian and Tertiary units in the vicinity of a subsurface pluton (assumed to be Cretaceous) that possibly acts as a doorstop and is not deformed, although the less competent units deform around it. (2) Devonian units were deformed into the dome shape during the intrusion of the subsurface pluton, and subparallel bedding in the Tertiary units is a coincidence and unrelated to the dome-like structure. Tertiary units are in angular unconformity with Devonian units at depth and truncate against them. (3) Dome-like structure is the result of egg-crate style folding, where regional eastwest folds meet an earlier north-south fold (proposed by Freeman and others [1987], who also noted this feature). Aeromagnetic data suggest a large intrusive body underlies this area, consequently, we prefer some combination of models 1 and 2. The underlying pluton is discussed in more detail below (p. 22).

The majority of faults on the map displace the Nenana Gravel and (or) Usibelli Group, indicating some movement on these faults must be of middle Tertiary age or younger. The relative timing of these faults is unclear. The northwest-, northeast-, and east-westtrending faults do not terminate in any particular pattern, which suggests that they all might have been (or are still) part of the same structural system. The northwest- and northeast-trending faults may be activated fracture sets. Where Tertiary units are offset by these faults, the faults appear to have significant movement. Where these faults occur within homogeneous Paleozoic rocks, it is difficult to determine if significant movement has occurred. For instance, in the California Creek canyon, where continuous exposures of bedrock allow for detailed observation of structures, several crosscutting faults were noted. These faults are expressed as heavily iron-stained, silicified shear zones ranging from 0.75 up to about $5 \mathrm{~m}$ wide with highly fractured rock and rock flour. We assume that shear zones of this magnitude have had significant movement along them.

The east-west-trending faults may be reactived, and at least several hundred meters of vertical offset is suspected along them. The two parallel, east-west-trending faults in the southeast corner of the map area juxtapose the older Keevy Peak Formation against the California Creek Member of the Totatlanika Schist. The east-west-trending Eva Creek high-angle $\left(57-90^{\circ}\right)$ fault displaces mineralization and hornfels in the Liberty Bell Mine area. The Eva Creek fault is composed of several subparallel splays. The dip and dip direction of the longest strand is unknown; geologic mapping indicates that the southern side of the fault is down-thrown. Its trace at a scale of 1:50,000 does not appear to be topographically controlled, and therefore the longest strand is probably a high-angle fault. Freeman and others (1987) noted a $70^{\circ}$, north-dipping splay with reverse motion (south- side-down) immediately south of the longest strand. Approximately $120+\mathrm{m}$ of offset is indicated from drill results. Conversely, plots of ore-element concentrations from rock samples suggest that relative movement on the Eva Creek fault is south-side-up. Te and $\mathrm{Cu}$, elements found more proximal to plutons in hydrothermal systems, are concentrated south of the fault while Sb, $\mathrm{Pb}$, and $\mathrm{Zn}$, elements found more distal to plutons in hydrothermal systems, are more concentrated to the north of the fault (fig. 8). This elemental evidence suggests a possible vertical offset of more than 300 meters. Either the Eva Creek fault was reactivated later within a different stress regime or the fault is actually composed of several en echelon faults with different directions and amounts of offset. This fault is important because it offsets a magnetic high mapped as pyrrhotite-bearing hornfels and the ore-element geochemical anomalies discussed above.

Additional observations of structures made by Freeman and others (1987) are noted here. In the Liberty Bell Mine area, broad, open, vertical, north-northwest-trending folds with asymmetrical, small-scale, brittle kink folds formed axial plane fractures that host tourmaline, sulfide, and gold vein mineralization. The axial plane fractures probably acted as conduits for hydrothermal fluids. In Moose Creek, tensional gashes oriented $\mathrm{N} 75^{\circ} \mathrm{W}$ that also host gold-bearing quartz-sericite-arsenopyrite veins are associated with shear pairs trending $\mathrm{N}^{\circ} 5^{\circ} \mathrm{E}$. Freeman and others (1987) also noted isoclinal folds in metamorphosed rock outcrops with their axial planes subparallel to foliation, and a possible second isoclinal fold direction with fold axes rotated $90^{\circ}$ horizontally from the first direction.

\section{MINERALIZATION AND CRETACEOUS INTRUSIONS}

Lode mineralization in the study area is widespread along the broad east-west-trending ridge of Paleozoic metamorphic rocks that crosses the middle of the map area (Freeman and Shaefer, 2001; Athey and others, 2005; appendix G). Mineralization and (or) hornfels occur in all of the Paleozoic units except those in the area that corresponds with Wahrhaftig's (1970c) Keevy Peak Formation, quartz metawacke (unit Dqw) and graphitic quartzite (unit Dgq). In addition, some granite (unit Kg) and granodiorite (unit Kgd) bodies are altered and mineralized. The lode occurrences include arsenopyrite \pm gold \pm bismuth minerals \pm stibnite \pm tourmaline + quartz veins and replacements, and pyrrhotite \pm gold \pm arsenopyrite + actinolite + biotite skarn (this study; Yesilyurt, 1996). Skarn mineralization occurs in metasomatized carbonate-altered metabasite (unit $\mathrm{Db}$ ) and possibly unrecognized calcareous sediments. $\mathrm{Cu}-, \mathrm{Sb}-, \mathrm{Pb}-$ and Zn-bearing ore minerals are associated with gold-arsenopyrite mineralization and (or) are present as distal 

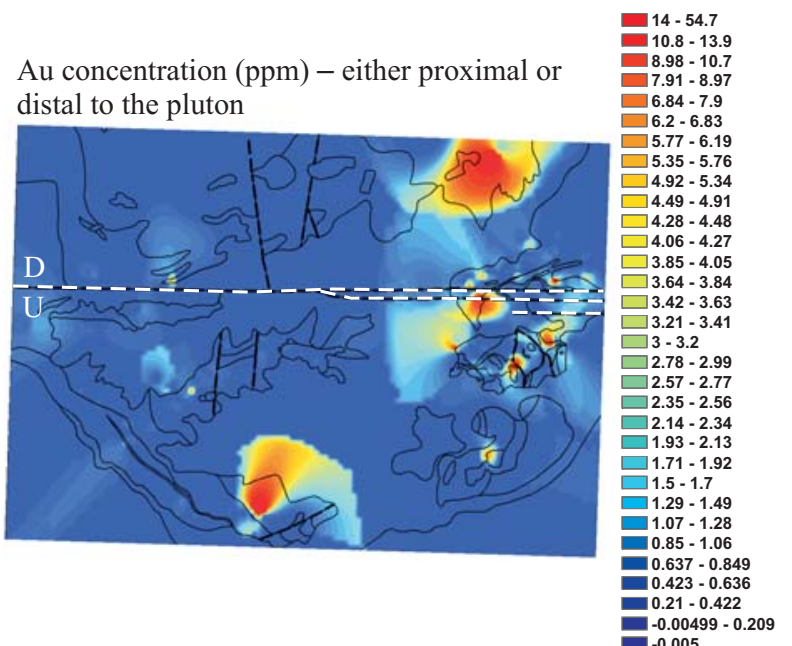

Te concentration (ppm) - proximal to the pluton

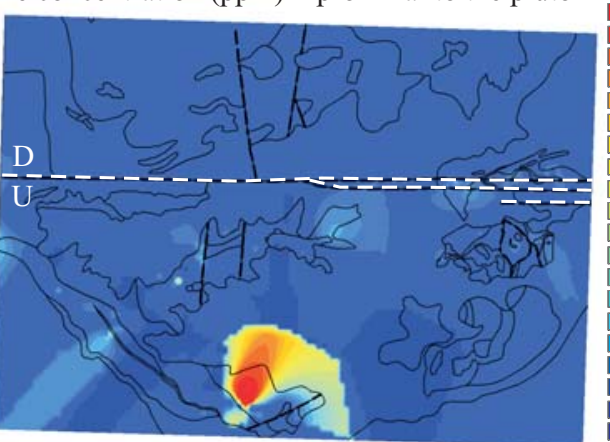

$16.42-88.40$

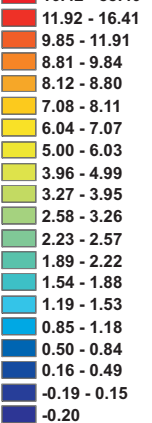

$-0.005$

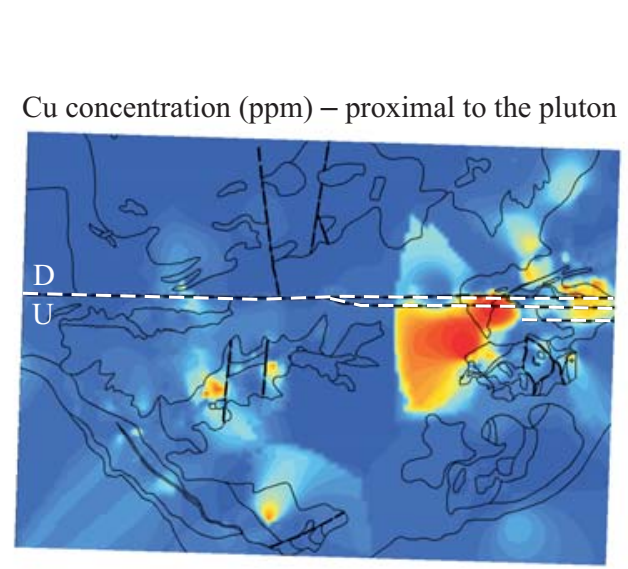

$4,664-9,628$ $2,783-3,572$ $1,994-2,33$
$1,730-1,993$ $1,730-1,993$
$-1,505-1,729$ $1,279-1,504$
$\square \quad 1,279-1,278$ $903-1,015$ $\square$
$\square 28$ - 902
$752-827$ $\square 752-827$
$\square \quad 677-751$ $\square 639-676$
$\square \quad 602-638$ $\square 02-638$
$\square 564-601$
$\square$ $527-563$
$\square 489-526$ $\begin{array}{r}489-526 \\ \square 451-488 \\ \hline\end{array}$ $414-450$
$376-413$ $376-413$
$-339-375$
$-301-338$ $263-300$
$-226-262$ $226-262$
$-188-225$ $188-225$
$-150-187$
$-113-149$ $113-149$
$-75-112$ - $38-74$ D-1

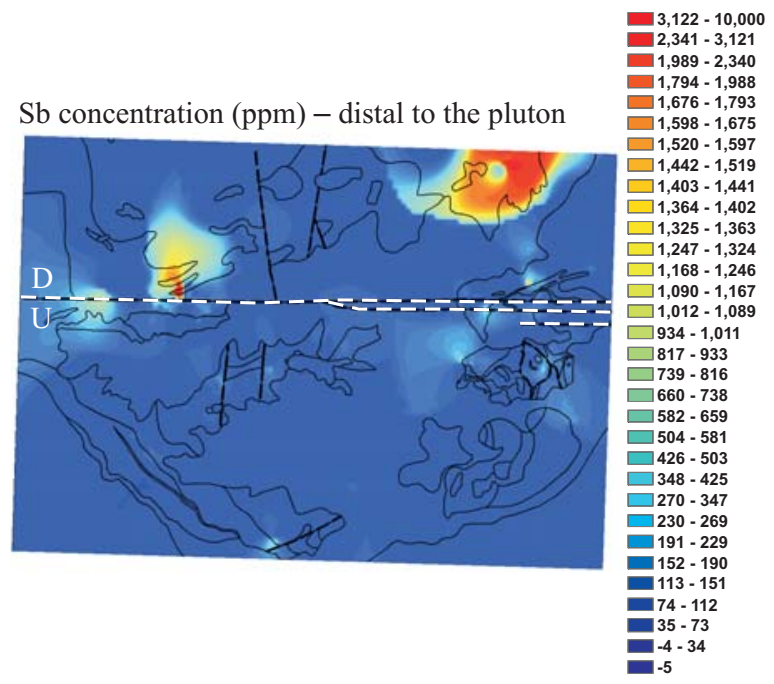

$3,122-10,000$
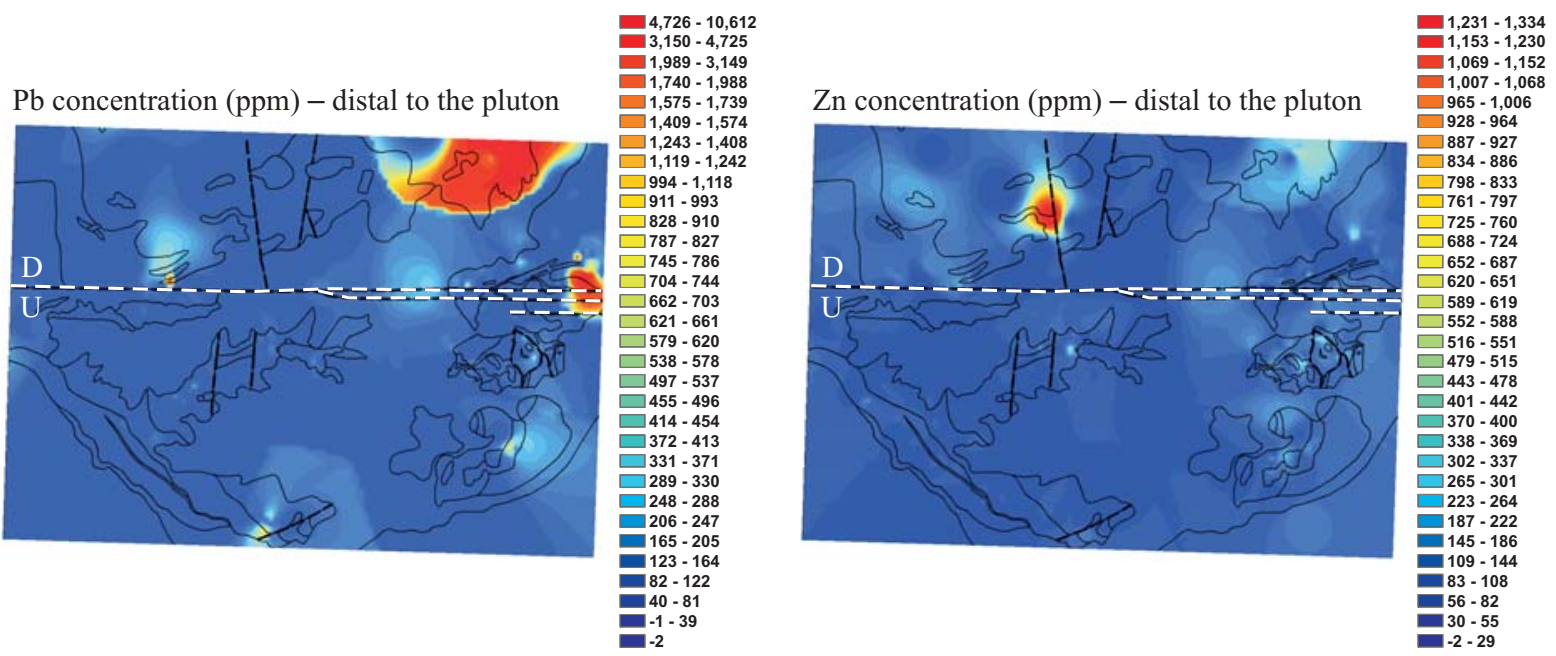

Figure 8. Gridded ore-element data from rock samples in the Liberty Bell Mine area. Grid method is Inverse Distance Weighted Interpolation with a power of 4. All elemental grids were plotted from ESRI ArcMap using Quantile classification with 32 classes, except Te, which had 20 classes, and Zn, which was plotted using Jenks Natural Breaks classification with 32 classes. Negative concentrations represent below-detection-limit data. Eva Creek fault is highlighted in white. Data from Galey and others, 1993; Bidwell, 1994; Yesilyurt, 1994, 1996; and Athey and others, 2005. 
expressions of $\mathrm{Au}-\mathrm{As}-\mathrm{Bi}$ mineralization. Enriched gold values are associated with potassium silicate (alkali feldspar-biotite-tourmaline-quartz), chlorite-sericitequartz, and widespread quartz-sericite alteration assemblages (Yesilyurt, 1996). Tourmaline is rarely found in Interior plutonic systems; three exceptions are Vinasale (Bundtzen, 1986), Democrat (McCoy and others, 1997), and possibly Nixon Fork (L.K. Freeman, oral commun., 2006).

Hydrothermal activity is not restricted to any one Paleozoic unit, and is texturally expressed as simple brittle veins, stockwork vein sets, breccias, and (or) replacement zones. Hydrothermal minerals include varying proportions of white- to gray-colored quartz, fine-grained, acicular, felted masses of medium brown (less commonly medium green) tourmaline, fine-grained white mica, arsenopyrite, and stibnite. Native gold in Moose Creek is associated with light green-gray, locally felted, tourmaline-monazite-quartz veins that cross-cut earlier dark brown massive biotite and quartz veins and breccia (Ray “Mudd” Lyle, oral commun., 2006; XRF data, this study). Timothy Ruppert (oral commun., 2005) reported native gold in crushed granodiorite in Little Moose Creek.

In the western half of the map area, an approximately 8 by $5.5 \mathrm{~km}$ magnetic high in airborne magnetic data (Burns and others, 2002) delineates a zone of hornfelsed metasedimentary and meta-igneous rocks (units Daw, Dq, Dgq, Dar, Dr, Dg, and Db), which suggests a large intrusion underlies the granite (unit Kg) and granodiorite (unit Kgd) dikes and stocks exposed the surface. These granitic intrusions are interpreted to be genetically related to the hydrothermal event responsible for forming the Liberty Bell Mine gold deposit and other nearby gold occurrences. This interpretation is based on the close spatial association between these intrusions and gold-bearing veins and rocks, and comparison of the geochemical signature of gold-bearing rocks to other Interior Alaska gold deposits of this age (e.g., Fort Knox). Hydrothermal biotite and sericite are consistently 92-93 Ma. Secondary biotite from a quartzorthoclase-biotite-tourmaline-sulfide vein that cross-cuts fine-grained phyllite yielded a K-Ar age of $91.6 \pm 0.9 \mathrm{Ma}$ and sericite from a quartz-sericite-tourmaline-sulfide alteration zone associated with a crosscutting felsic dike yielded a K-Ar age of 93.0 $\pm 1.0 \mathrm{Ma}$ (Yesilyurt, 1996). Biotite-altered arkosic metawacke yielded an ${ }^{40} \mathrm{Ar} /{ }^{39} \mathrm{Ar}$ plateau age of $92.0 \pm 0.5 \mathrm{Ma}$ (map location A3; table 5; this study). These ages match the age of the granodiorite intrusions $\left({ }^{40} \mathrm{Ar} /{ }^{39} \mathrm{Ar}\right.$ biotite plateau age of $91.6 \pm 0.5 \mathrm{Ma}$, map location $\mathrm{A} 2 ;{ }^{40} \mathrm{Ar} /{ }^{39} \mathrm{Ar}$ biotite plateau age of $92.9 \pm 0.5 \mathrm{Ma}$, map location A4; table 5), and by inference, the granite intrusions.
Several lines of evidence suggest that the Liberty Bell pluton is emplaced $>300$ m below the presently exposed mineralization. Placer gold from Little Moose Creek has a fineness of $\sim 830$, and contains $\sim 6$ percent $\mathrm{Hg}$ and $<0.01$ percent $\mathrm{Cu}$ (this study, table 6 ). The gold nuggets analyzed are subangular to subrounded, with dimensions of $1-3 \mathrm{~mm} \times 1-3 \mathrm{~mm} \times 0.3-0.6 \mathrm{~mm}$, that is, with a length:width:height ratio of approximately 4:4:1. Surface roughness is readily apparent on most grains. Polishing revealed no obvious silver-depleted rim. The chemistry of the placer gold is similar to that of other typical lower-temperature, plutonic-related gold systems in Interior Alaska (fig. 9a). Figure 9b shows that gold of this composition is usually formed at temperatures of $300-400^{\circ} \mathrm{C}$. The lack of high-temperature skarn mineralization is another indicator that the fluids were moderately cool at this distance (300-1,000 m) from the pluton, perhaps around temperatures of $300-350^{\circ} \mathrm{C}$. By extrapolation, the size of the hornfelsed area indicates the maximum depth at which the pluton can be buried. Two examples of hornfelsing from Interior Alaskan plutons intruding low grade metamorphic rocks are Elephant Mountain (a 2-3-km-diameter pluton with a 300-m-thick hornfels rim) and Approach Hill (a 2-km-diameter pluton with a 200-m-thick hornfels rim; R.J. Newberry, oral commun., 2006). If the Liberty Bell pluton really is 2-4 times larger than the Elephant Mountain and Approach Hill plutons, as the aeromagnetic geophysical data suggest, one would expect a hornfels rim 400-1,200 m thick. Not accounting for variables such as topography, extent of hornfels already eroded, and surface irregularity of the pluton, gold chemistry and hornfels extent suggest the pluton lies at a depth between 300 and 1,200 m below the present-day surface.

Another potential source of mineralization may be present in the map area. The Tertiary Suntrana Formation (unit Tsn) forms a cap on one of the hills just west of California Creek. Although this unit typically consists of unconsolidated sand and gravel, at this location it forms massive, cliff-forming outcrops of silica-cemented sand and gravel. Along California Creek,

Table 6. Placer gold composition from Little Moose Creek. Average of fifteen analyses. Composition by X-Ray fluorescence (XRF) at the University of Alaska Fairbanks.

\begin{tabular}{lcc} 
Element & Average (Wt.\%) & Std. Dev. \\
$\mathrm{Au}$ & 82.5 & 1.4 \\
$\mathrm{Ag}$ & 16.9 & 1.5 \\
$\mathrm{Hg}$ & 0.57 & 0.2 \\
$\mathrm{Cu}$ & 0.005 & 0.004 \\
Fineness & 830 & $+/-15$ \\
\hline
\end{tabular}




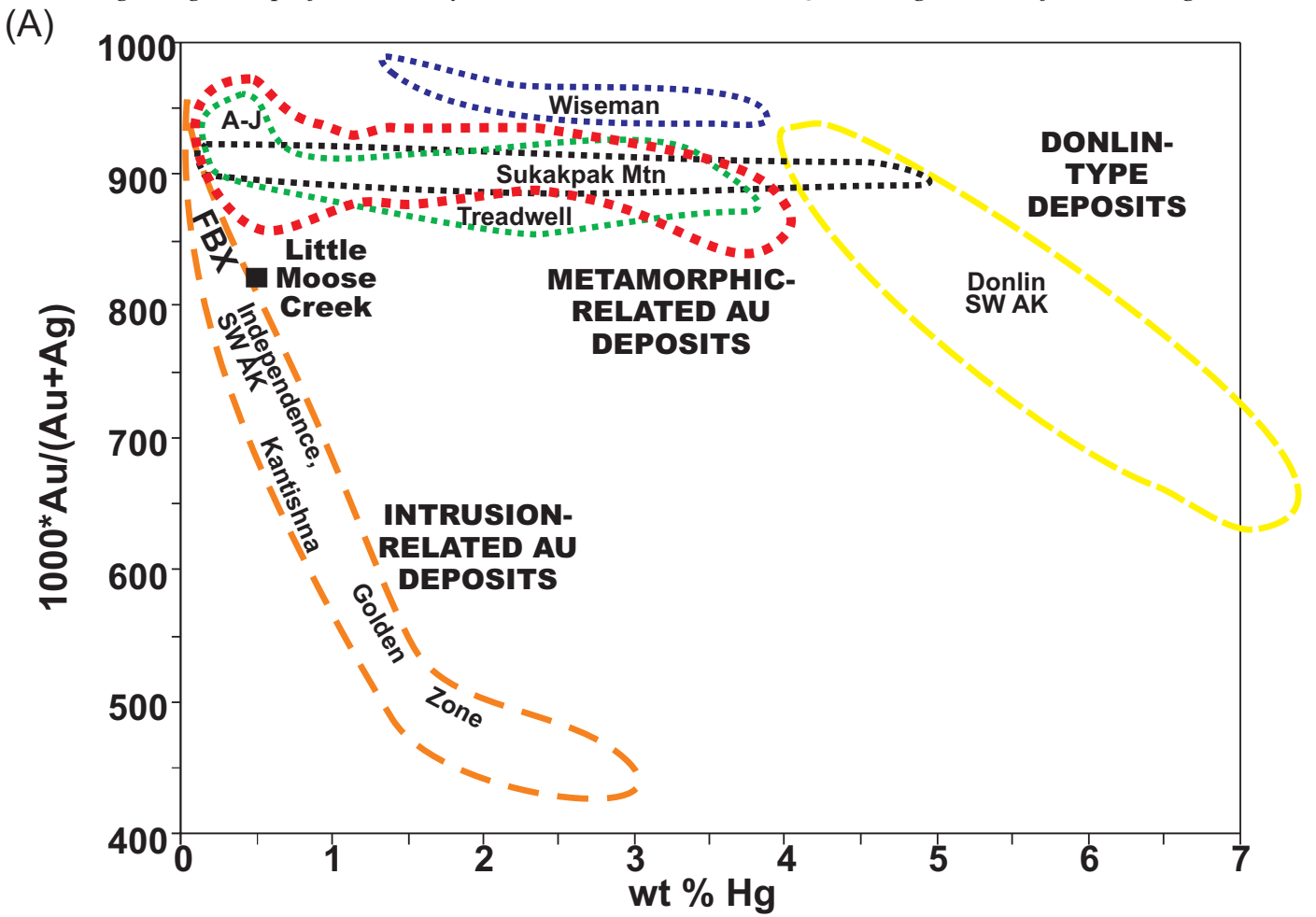

(B)

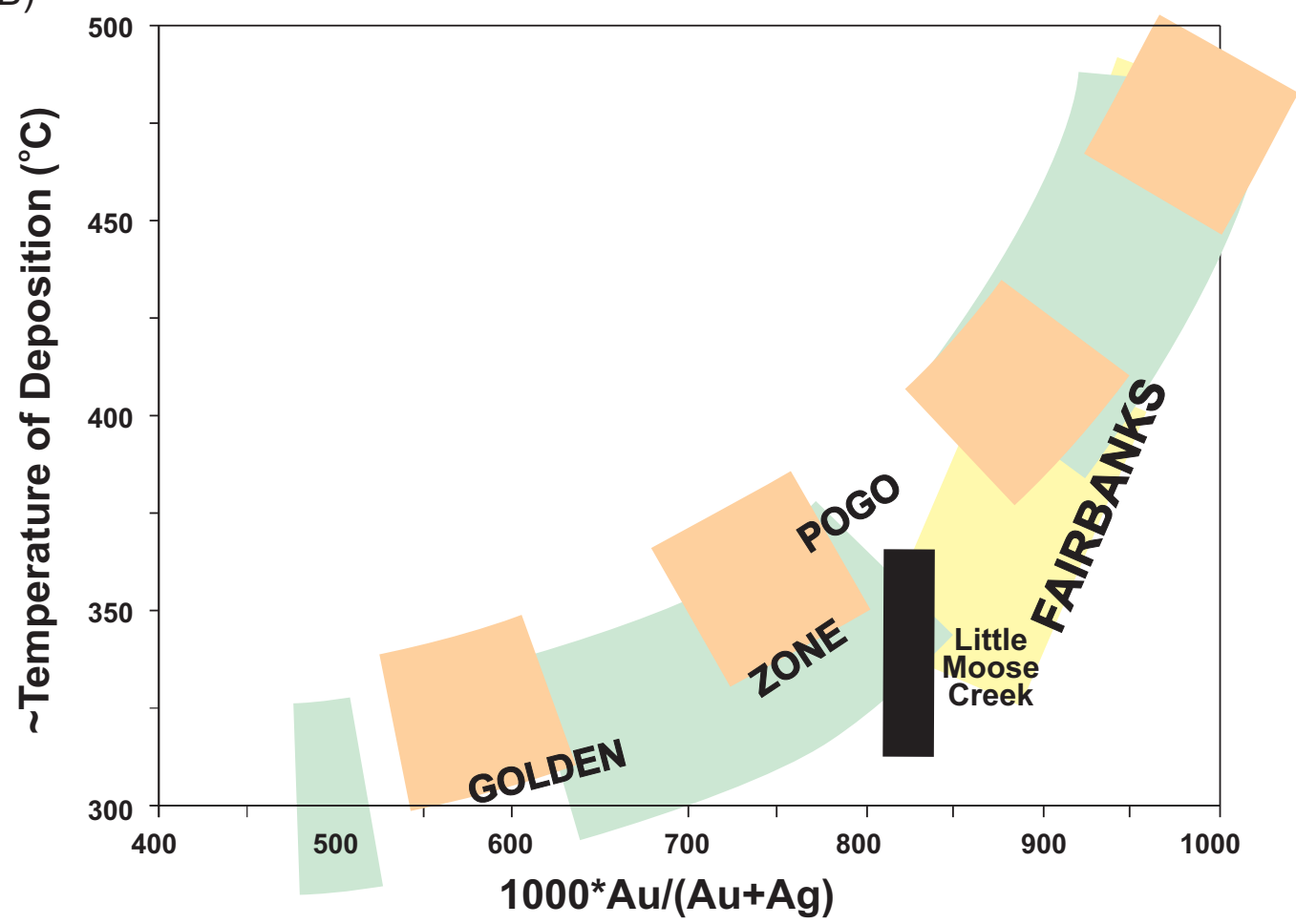

Figure 9. Typical(?) gold composition patterns for Interior Alaskan intrusion-related deposits. Unpublished data from R.J. Newberry, 2006. (A) Gold fineness versus mercury content. (B) Approximate temperature of gold deposition versus gold fineness. 
at least one of the high-angle faults cutting the Paleozoic rocks is highly sheared, and the fault gouge and adjacent wall rocks are silicified. At other localities, the Paleozoic rocks are cut by shear veins containing quartz, arsenopyrite, and \pm pyrite. The presence of silica-rich pore fluids within the Tertiary Suntrana Formation, and potentially(?) some of the arsenic-bearing shears in California Creek, indicate the presence of a young $(<15$ Ma) hydrothermal system.

There are three obvious exploration targets for a plutonic-related gold system in the Liberty Bell area. The first is a Ft. Knox-type intrusion-hosted target, which would have a larger ore body with a lower grade. Because the Liberty Bell pluton is probably deeper than
$300 \mathrm{~m}$, this target is unattractive. The second type of target is replacement and skarn formed in calcareous units Db and any available calcareous sedimentary rocks. This type of ore body would have a smaller extent but higher grade. The third type of target is ore formed within structurally controlled veins or stockworks, again a smaller but high-grade ore body. Both replacement/skarn and structurally controlled mineralization are documented at Liberty Bell; however, more exploration is needed to delineate an economic deposit from the significant and widespread mineralization. The only significant hindrance to mineral exploration and possible future mine development is the Tertiary cover.

\section{UNIT DESCRIPTIONS}

\section{TERTIARYSEDIMENTARYROCKS}

Tn NENANA GRAVEL (Pliocene)—Light brown to orange-brown, poorly consolidated, clast-supported pebble conglomerate and sandstone. Conglomerate layers are commonly 1-60 $\mathrm{cm}$ thick but range up to 5 $\mathrm{m}$ thick. Gravel is well rounded to subrounded, averaging 5-30 $\mathrm{mm}$ in diameter with clasts up to $45 \mathrm{~cm}$ in diameter. Composition of gravel and larger clasts is $20-50$ percent quartz and quartzite, $10-30$ percent black and other chert, 10-80 percent plutonic (granite, gabbro, diorite), $<20$ percent volcanic (basalt, latite, diabase, andesite, porphyry), $<20$ percent metamorphic (phyllite, schist, orthogneiss), and $<10$ percent sedimentary (Cantwell Formation conglomerate, siltstone, mudstone, sandstone; not including chert). Gravel layers are commonly cemented with iron oxides forming ferricretes. Sites rich in gabbro cobbles and boulders, located in the northwest corner of the map area, possibly correlate with the upper $305 \mathrm{~m}$ of the Nenana Gravel section (Wahrhaftig, 1987) or the gabbro could be glacially transported (De Anne Stevens, oral commun., 2006). Gravel layers are interbedded with gray to pale brown to orangebrown, locally silty and clayey, very fine- to coarse-grained sand layers 5-20 cm thick, but up to $10 \mathrm{~m}$ thick. Sand is composed of quartz grains and sedimentary lithic fragments with significant but lesser amounts of feldspar grains and metamorphic, volcanic, and plutonic fragments (table 2). Clay fraction of the sand is composed of a small to moderate amount of kaolinite and montmorillonite, and possible zeolite and chlorite (table 3). Unit also contains thin, gray to orange clay layers, clay concretions up to $10 \mathrm{~cm}$ in diameter, and thin lignite layers with occasional plant remains (one $\log 10 \mathrm{~cm}$ in diameter). Magnetic susceptibility is low to moderate (0.00-1.34 averaging $0.22 \times 10^{-3}$ SI [Système International]). Visual observations and measurements of cross-bedding generally indicate a northeastward paleocurrent direction (fig. 4). Possibly conformable on the Lignite Creek Formation in the southwestern corner of the map, but unconformable on a variety of units elsewhere in the map area. The intervening Grubstake Formation was not recognized in this map area. Wahrhaftig and others (1969) pinch the Grubstake Formation out along Elsie Creek, which crosses the southern boundary of the map area. Age from palynological and paleobotanical data (Wolfe and Tanai, 1980; Leopold and Liu, 1994). Maximum measured thickness is approximately 1,040 m in the headwaters of Suntrana Creek, located $15 \mathrm{~km}$ south of the map area (Wahrhaftig, 1987). Interpreted as coalescing alluvial fans shed during uplift of the Alaska Range (Wahrhaftig, 1987).

Tlc LIGNITE CREEK FORMATION (Late Miocene) — Very fine- to medium-grained sandstone and gravel. Sandstone is white, light gray, cream, and orange, well sorted, well rounded, and rarely coarse-grained with $<2$ percent granules. The sand fraction is composed primarily of quartz grains and metamorphic lithic fragments, and lesser feldspar grains, sedimentary lithic fragments, and volcanic lithic fragments. Plutonic lithic fragments are rare (table 2). Beds are occasionally micaceous, contain clay concretions, and the silt content varies widely. The clay fraction of the sandstone is composed of low to moderate amounts of kaolinite, moderate to no amounts of montmorillonite (occasionally higher amounts), and possible zeolite and chlorite (table 3). Sandstone beds 3-4.5 m thick are commonly interbedded with light brown to 
orange-brown, poorly sorted conglomerate layers $1-4 \mathrm{~cm}$ thick to less commonly $30.5-60 \mathrm{~cm}$ thick. Crossbedding is infrequently observed in outcrop. Outcrops are generally composed of $<5$ percent, but up to 30 percent, conglomerate. Pebbles and cobbles in the conglomerate are well rounded to subangular and $0.5-8 \mathrm{~cm}$ in diameter (averaging $1 \mathrm{~cm}$ in diameter; rare cobbles up to $25 \mathrm{~cm}$ in diameter). Composition of clasts is $10-50$ percent quartz, 35-50 percent metamorphic (black quartzite, other quartzite, quartz schist, slate, gneiss, greenstone), $20-50$ percent chert (10-40 percent black chert, $0-5$ percent red chert), $10-40$ percent plutonic (gabbro, diorite, granite, clinopyroxenite?), 5-20 percent volcanic (basalt, rhyolite, hornblende andesite, dacite?), and $0-5$ percent sedimentary (Cantwell Formation conglomerate, argillite, sandstone, limestone). Locally iron cemented, forming ferricrete and occasionally contains iron concretions $2-15 \mathrm{~cm}$ in diameter. Unit also contains platy- to blocky-parting, light gray to brown shale $<57 \mathrm{~cm}$ thick and friable coal $<0.7 \mathrm{~m}$ thick (apparent coal rank is Lignite A; table F1). Magnetic susceptibility is low to moderate $\left(0.00-3.44\right.$, averaging $0.22 \times 10^{-3} \mathrm{SI}$; one sandstone sample registered $\left.20.5 \times 10^{-3} \mathrm{SI}\right)$. Visual observations and measurements of cross-bedding generally indicate a southward or westward paleocurrent direction (fig. 4). Conformably overlies the Suntrana Formation (Wahrhaftig and others, 1969). Age from paleobotanical data (Wolfe and Tanai, 1980). Thickest measured section is $244 \mathrm{~m}$ in the Wood River coal basin, located $45 \mathrm{~km}$ east of the map area (Wahrhaftig and others, 1969). Interpreted as point bar deposits, gravelly and sandy braided stream deposits, and lesser overbank deposits (Buffler and Triplehorn, 1976; Stanley and others, 1992).

Tsn SUNTRANA FORMATION (Middle Miocene) - Fine- to medium-grained with minor very fine- to coarsegrained, "salt and pepper" sandstone and conglomerate. Sandstone has an overall gray to light yellowbrown color. Rarely beds are iron-oxide stained. Sandstone is well-sorted, rarely clayey (kaolinite > montmorillonite) or silty and is composed primarily of quartz, minor feldspar grains, and lesser sedimentary and metamorphic lithic fragments; volcanic and plutonic lithic fragments are rare (table 2). Conglomerate beds $10-70 \mathrm{~cm}$ thick occur in about $5-50$ percent of the outcrops. Conglomerate is composed of 25-80 percent white quartz, 15-50 percent black chert, 20-25 percent white and black quartzite, 5-60 percent metamorphic clasts (schist, phyllite), $<10$ percent red and green chert, $<5$ percent granitic rocks and minor conglomerate, diabase, and porphyritic igneous rocks. Gravel averages $1-2 \mathrm{~cm}$ in diameter (ranges $3 \mathrm{~mm}$ to $10 \mathrm{~cm}$ ). Outcrops contain fining-upward sequences and cross-bedding. Unit also contains glassy, conchoidally fracturing coal up to $6 \mathrm{~m}$ thick (apparent coal rank is Lignite A and B and Highvolatile Subbituminous C; table F1) and gray to chocolate brown, platy, friable shale. Magnetic susceptibility is variable $\left(0.0-13.0\right.$, averaging $1.32 \times 10^{-3} \mathrm{SI}$; coal had magnetic susceptibilities up to $\left.43.4 \times 10^{-3} \mathrm{SI}\right)$. Cross-bedding in the Suntrana Formation throughout the Nenana coal basin generally indicates a southor westward paleoflow (Wahrhaftig and others, 1969; Ridgway and others, 1999). Unit is almost entirely burnt in the Rex Dome area, and local, small pockets of clinker occur south of hill VABM Coal. In the field area, Suntrana Formation may conformably overlie Healy Creek Formation without the intervening Sanctuary Formation. Sanctuary Formation as described by Wahrhaftig and others (1969) and Wahrhaftig (1987) was not recognized in the field area. Assigned stratigraphic age from paleobotanical data (Wolfe and Tanai, 1980). Thickest section of unit is $393 \mathrm{~m}$ on Coal Creek, tributary of Healy Creek, $13.5 \mathrm{~km}$ south of the map area (Wahrhaftig and others, 1969). Interpreted as high-energy fluvial channels filled by gravel and sand bars (Buffler and Triplehorn, 1976; Wahrhaftig, 1987; Stanley and others, 1992).

The HEALY CREEK FORMATION (Early Miocene-Early Oligocene/Late Eocene?)—Interbedded, poorly sorted pebbly sandstone, siltstone, claystone, conglomerate, and coal. Sandstone is white to light gray, very fine- to fine-grained, with lesser medium- and coarse-grained sandstone; it contains about 60-80 percent sand, 5-40 percent pebbles, and 5 percent cobbles. Sand is composed of quartz grains, metamorphic rock fragments, feldspar grains, minor sedimentary rock fragments, and rare plutonic or volcanic rock fragments. Brown to gray, platy, micaceous siltstone and claystone (primarily kaolinite) weathers bright white, locally exhibits varves, and frequently contains subangular to angular, 2-3 mm quartz and chert granules. White to light brown conglomerate contains well rounded to subangular gravel $1-3 \mathrm{~cm}$ in diameter (up to $40 \mathrm{~cm}$ in diameter) in a sandy + silty + clayey matrix. Gravel is composed of 30-92 percent quartz, 20-45 percent locally derived metamorphic clasts, 5-45 percent chert, 5 percent red chert, and rare quartzite and granite. Platy, friable, locally resinous coal beds are $8 \mathrm{~cm}$ to $2.5 \mathrm{~m}$ thick (apparent coal rank is Lignite A and B and High-volatile Subbituminous C; table F1). On the northern edge of the map, one 
outcrop contains at least 14 fining-upward sequences of pebbles to 8-cm-thick coal beds. Magnetic susceptibility is moderate $\left(0.0-1.49\right.$, averaging $\left.0.43 \times 10^{-3} \mathrm{SI}\right)$; coal exhibits magnetic susceptibilities up to $11.5 \times 10^{-3}$ SI. Unit is commonly burnt north of hill VABM Coal. Cross-bedding in the Healy Creek Formation throughout the Nenana coal basin indicates a variety of paleocurrent directions (Wahrhaftig and others, 1969; Ridgway and others, 1999). Unit was deposited on an irregular surface, infilling valleys (Wahrhaftig and others, 1969); significant thickness changes over short distances and unit's composition was heavily influenced by surrounding bedrock. Assigned stratigraphic age from palynological and paleobotanical data (Wolfe and Tanai, 1987; Leopold and Liu, 1994). Thickness of unit in the map area is unknown; unit is $350 \mathrm{~m}$ thick at the eastern edge of the Healy Creek coal basin, $13 \mathrm{~km}$ south of the map area (Wahrhaftig and others, 1969). Interpreted as sand and gravel bars in shallow, low-sinuosity channels of high-energy, braided streams and fine-grained sediment deposited in abandoned, quiet-water stream channels (Buffler and Triplehorn, 1976; Wahrhaftig, 1987; Stanley and others, 1992).

\section{TERTIARY-CRETACEOUS IGNEOUSROCKS}

Td DACITE FLOWS (Tertiary)—Fine-grained, massive, jointed ( \pm columnar?), porphyritic flows crop out in the southeastern map area. Unit is at least $200 \mathrm{~m}$ thick. Light- to dark-green colored, with varying proportions of hornblende, biotite, pyroxene, plagioclase, and (or) quartz phenocrysts up to $6 \mathrm{~mm}$ in length in an aphanitic groundmass. Modal composition is 62 percent plagioclase, 10 percent hornblende, 20 percent quartz, 3 percent pyroxene, 3 percent biotite, and 2 percent opaque minerals (both magnetite and ilmenite? based on shapes). Secondary chlorite partially to completely replaces mafic minerals. Major- and minoroxide and trace-element analyses indicate the dacite flows are calc-alkalic and likely to be subduction related (fig. 7). Magnetic susceptibility is high (1.00-10.00, averaging $\left.3.78 \times 10^{-3} \mathrm{SI}\right)$. Unit corresponds to a pronounced magnetic high in airborne geophysical data (Burns and others, 2002). ${ }^{40} \mathrm{Ar} /{ }^{39} \mathrm{Ar}$ biotite plateau age of $37.4 \pm 0.3 \mathrm{Ma}$ (map location A1; table 5). This unit is not related to the Jumbo Dome intrusive center, located $3 \mathrm{~km}$ south of the map border. Jumbo Dome is a much younger system $\left({ }^{40} \mathrm{Ar} /{ }^{39} \mathrm{Ar}\right.$ hornblende weighted average age of $1.026 \pm 0.057 \mathrm{Ma}$ ) and compositionally an Adakite (Sr:Y ratio approximately 1,000:1; C.J. Nye, written commun., 2006), while the Sr:Y ratio of this unit is 7:1. The closest, dated, volcanic rock of that approximate age is from Sugar Loaf Mountain, a fossilized volcanic vent located $24 \mathrm{~km}$ to the south (K-Ar ages of $32.4 \pm 1.0$ to $35.2 \pm 1.0 \mathrm{Ma}$; Albanese and Turner, 1980). Unit is offset by a late, north-northeast-trending, high-angle fault.

Kg GRANITE DIKES AND STOCKS (Cretaceous) - Fine- to very fine-grained, porphyritic-textured, lesser equigranular-textured, and rarely pegmatitic-textured, hypabyssal granite dikes (up to $10 \mathrm{~m}$ wide; average less than $3 \mathrm{~m}$ wide) and stocks (at least $1.2 \mathrm{~km}$ long and $0.3 \mathrm{~km}$ wide) are present throughout the map area. Orange to light yellow-brown weathering, white to light gray colored. Porphyritic intrusions contain widely varying proportions of quartz, feldspar, and \pm biotite phenocrysts (10-42 percent; average 21 percent) in an aphanitic to finely granular matrix. Modal composition ranges from 2-38 percent quartz (average 13 percent), 4-65 percent feldspar (average 16 percent), $0-7$ percent biotite, $0-2$ percent primary(?) tourmaline, and accessory sphene, zircon, rutile, and apatite. Freeman and others (1987) reported the presence of small, pink to red, clear, glassy euhedral garnets. Dikes that intrude graphitic phyllite (unit Dgq) north of Cody Creek in the western map area contain up to 3 percent graphite, and 70 percent perthite. Weight percent CIPW normative compositions were assigned to igneous rocks using the methodology of Irvine and Baragar (1971). The granite intrusions are locally intensely sericitized, silicified, and tourmalinized with occasional chlorite, epidote, and clinozoisite alteration. Associated mineralization includes arsenopyrite, scorodite, and stibiconite. Major- and minor-oxide and trace-element analyses indicate the granite intrusions are subduction-related and formed in an island-arc tectonic setting (fig. 7). Magnetic susceptibility is low (0.00-0.31, averaging $\left.0.05 \times 10^{-3} \mathrm{SI}\right)$. Age estimated to be $93 \mathrm{Ma}$ based on a $93.0 \pm 0.95 \mathrm{Ma} \mathrm{K}$-Ar age of sericite from a quartz-sericite-tourmaline-sulfide alteration zone associated with a cross-cutting felsic dike in the Liberty Bell Mine area (Yesilyurt, 1996) and spatial association with, and trace-element-indicated tectonic setting similarity to, unit Kgd.

Kgd GRANODIORITE DIKES AND STOCK (Cretaceous) — Fine- to medium-grained, porphyritic to equigranular granodiorite dikes (average $3 \mathrm{~m}$ wide) and stocks (at least $1.2 \mathrm{~km}$ long and $80 \mathrm{~m}$ wide) are present along Moose Creek, Little Moose Creek, and on the southern flank of hill VABM Coal. Brown weathering; 
white, light yellow-brown, and gray-green colored. Porphyritic intrusions contain highly variable proportions of quartz, feldspar, \pm biotite, and \pm hornblende phenocrysts (up to 65 percent; average 29 percent) in an aphanitic to finely granular matrix. Modal composition ranges from 0-15 percent quartz, 16-35 percent plagioclase, 16-30 percent K-feldspar, 0-30 percent hornblende, 0-28 percent biotite, and accessory apatite, zircon, rutile, and opaque minerals. Rock names were assigned from weight percent CIPW normative calculations; one sample from lower Moose Creek is a tonalite and may represent a more mafic phase of the pluton. Intrusions contain chlorite, epidote, \pm actinolite altered from hornblende and biotite, and are locally silicified and sericitized. Mineralization includes gold (panned from a crushed rock sample from Little Moose Creek; Timothy Ruppert, oral commun., 2005), pyrite, arsenopyrite, and scorodite. Major- and minor-oxide and trace-element analyses indicate the granite intrusions are subduction-related and formed in an island-arc tectonic setting (fig. 7). Magnetic susceptibility is low (0.00-0.31, averaging $0.05 \times 10^{-3} \mathrm{SI}$ ). ${ }^{40} \mathrm{Ar} /{ }^{39} \mathrm{Ar}$ ages of $92-93 \mathrm{Ma}$ (hornblende plateau age of $91.6 \pm 0.5 \mathrm{Ma}$ [map location A2]; biotite plateau age of $92.9 \pm 0.5 \mathrm{Ma}$ [map location A4]; table 5). Unit Kgd is possibly a more mafic, marginal phase of a larger, subsurface granitic(?) pluton.

GABBRO DIKES (Cretaceous) —Fine-grained, blocky to spheroidally weathering, equigranular to porphyritic gabbro dikes up to $3 \mathrm{~m}$ in width are present on hill VABM Coal in the eastern map area. Mediumbrown weathering, dark-green colored, with rare quartz- and calcite-filled amygdules up to $5 \mathrm{~mm}$ in diameter. Porphyritic dikes contain plagioclase phenocrysts up to $1 \mathrm{~cm}$ in length. Modal composition ranges from 55 to 58 percent plagioclase, 0-38 percent hornblende, 3-25 percent biotite, 0-15 percent olivine, $0-5$ percent opaque minerals, and accessory apatite. Secondary minerals include talc, chlorite, calcite, quartz, and (or) white mica. Major- and minor-oxide and trace-element analyses indicate the gabbro dikes are subduction-related and formed in an island-arc tectonic setting (fig. 7). Magnetic susceptibility is moderate to high $\left(0.30-1.95\right.$, averaging $\left.2.57 \times 10^{-3} \mathrm{SI}\right) .{ }^{40} \mathrm{Ar} / 39 \mathrm{Ar}$ biotite plateau age of $95.6 \pm$ $0.5 \mathrm{Ma}$ (map location A5; table 5). Unit Kb is about 3 million years older than unit Kgd; the two igneous units may not be genetically related.

\section{PALEOZOIC UNITS}

Dg METAGRANITE (Devonian)—Megacrystic to lesser fine-grained, equigranular to porphyritic metagranite. Orange weathered; white, light green, and light gray colored. Foliated outcrops break in semi-massive blocks to schistose sheets. Modal composition is 10-40 percent relict quartz phenocrysts (average 22 percent) and 10-65 relict feldspar phenocrysts (average 34 percent). Metagranite is defined as having relict quartz + feldspar phenocrysts $>60$ percent based on typical textures exhibited by extrusive volcanic and hypabyssal rocks (K.F. Bull, oral commun., 2006). Megacrystic samples from Rex Dome and other similar bodies in the northern map area, which contain relict feldspar phenocrysts 1.5-3.0 cm (average 1.6 $\mathrm{cm}$ ) and relict quartz phenocrysts $1-10 \mathrm{~mm}$ (average $4.3 \mathrm{~mm}$ ), artificially generate low modal compositions because not every small sample or thin section contains the correct ratio of megacryst to matrix. Megacrystic samples are assumed to be metagranite instead of metarhyolite. Porphyritic samples with high crystal contents may represent a continuous increase in relict phenocrysts from metarhyolite, unit Dr. Conversely, groundmass composed of white mica and very fine-grained quartz and feldspar may have been seriate-textured before metamorphic recrystallization. Relict phenocrysts are commonly euhedral and sub-euhedral to less commonly spindle-shaped and sheared along foliation. Also contains biotite, chlorite (from biotite), rutile, epidote, clinozoisite, zircon, sphene, and opaque minerals. Rarely contains inclusions of unit Dgq. Weight percent CIPW normative composition is granite. Both varieties typically have $\mathrm{Nb}+\mathrm{Y}>50 \mathrm{ppm}$ and $\mathrm{TiO}_{2}<0.3 \mathrm{ppm}$. Metagranite is locally hornfelsed and mineralized by arsenopyrite, pyrite, and pyrrhotite as disseminated crystals and in cross-cutting quartz \pm tourmaline veins. Feldspars commonly, partially to wholly replaced by sericite and quartz. Magnetic susceptibility is low (0.0-0.6, averaging $\left.0.09 \times 10^{-3} \mathrm{SI}\right)$; hornfelsed samples containing pyrrhotite have magnetic susceptibilities up to $6.0 \times 10^{-3} \mathrm{SI}$. Major- and minor-oxide and trace-element analyses indicate the metagranite formed in a within-plate, extensional tectonic setting (fig. 7). Represents metamorphosed plugs, dikes, and (or) sills at least $3.4 \mathrm{~km}$ long and $0.6 \mathrm{~km}$ thick (probably stretched and thinned within foliation, respectively) emplaced within units Daw and Dgq. Where spatial extent is unknown, locations are marked with a symbol (see 'Map Symbols,' sheet RI 2006-2). Equivalent to augen gneiss in the California Creek Member of the Totatlanika Schist and comprises a portion of the area mapped as the Moose Creek Member of the 
Totatlanika Schist on Wahrhaftig's map (1970c) of the Fairbanks A-4 Quadrangle. Zircons from California Creek Member augen gneiss located about $37.5 \mathrm{~km}$ southeast of the map area and dated by SHRIMP U$\mathrm{Pb}$ exhibit an age of $373 \pm 3 \mathrm{Ma}$ (fig. 5; Dusel-Bacon and others, 2004).

Dr METARHYOLITE (Devonian) - Very fine- to medium-grained, porphyritic metarhyolite. Orange and brown weathered; white, gray, and light green colored and possibly flow banded. Forms massive, blocky outcrops with poorly formed foliation to well-foliated outcrops with strong cleavage. Modal composition is 1-40 percent relict feldspar phenocrysts (average 18 percent), 1-20 percent relict quartz phenocrysts (average 10 percent), and accessory apatite, zircon, and rutile. Feldspar crysts are $1-15 \mathrm{~mm}$ in diameter (average $2.3 \mathrm{~mm}$ ) and quartz crysts are $0.5-4 \mathrm{~mm}$ in diameter (average $1.8 \mathrm{~mm}$ ). Relict quartz (frequently embayed) and feldspar phenocrysts are euhedral to rarely subrounded, and frequently shattered and sheared in foliation. Groundmass is composed of very fine-grained $(<0.02 \mathrm{~mm})$, granular quartz, feldspar, and white mica. No tuffaceous textures are present. Metarhyolite is defined as having relict quartz + feldspar crystals $<60$ percent based on typical textures in extrusive volcanic and hypabyssal rocks (K.F. Bull, oral commun., 2006). Weight percent CIPW normative composition is primarily granite (rhyolitic texture); a few samples from the mine area are dacitic $\left(\mathrm{SiO}_{2}<68\right.$ percent). Metarhyolite typically has $\mathrm{Nb}$ $+\mathrm{Y}>50 \mathrm{ppm}$ and $\mathrm{TiO}_{2}<0.3 \mathrm{ppm}$. Where hornfelsed, metarhyolite contains biotite and (or) phlogopite, and is locally cross-cut and brecciated by quartz + sericite + tourmaline + arsenopyrite \pm pyrrhotite \pm pyrite(?) veins. Frequently samples have iron oxide pseudomorphs after pyrite(?) and feldspar is altered to sericite and quartz. Other alteration products include epidote, chlorite, and carbonate. Magnetic susceptibility is low $\left(0-0.8\right.$, averaging $\left.0.12 \times 10^{-3} \mathrm{SI}\right)$; hornfelsed samples have magnetic susceptibilities up to $3.07 \times 10^{-3}$ SI. Major- and minor-oxide and trace-element analyses indicate the metarhyolite formed in a within-plate, extensional tectonic setting (fig. 7). Represents flows or hypabyssal intrusions at least $5 \mathrm{~km}$ long and $0.4 \mathrm{~km}$ wide (probably stretched and thinned within foliation, respectively) that intrude units Daw, Dgq, and Dqw. Where spatial extent is unknown, locations are marked with a symbol (see 'Map Symbols,' sheet RI 2006-2). Equivalent to “Dacite crystal tuff” in Liberty Bell Mine sequence (Freeman and others, 1987) and comprises most of the area mapped as the Moose Creek Member of the Totatlanika Schist on Wahrhaftig's map (1970c) of the Fairbanks A-4 Quadrangle. Zircons from "Moose Creek Member" metarhyolite located about $39 \mathrm{~km}$ southeast of the map area and dated by SHRIMP U-Pb exhibit an age of $365 \pm 5 \mathrm{Ma}$ (fig. 5; Dusel-Bacon and others, 2004).

Dar APHYRIC METARHYOLITE (Devonian)—Aphyric, finely laminated, metamorphosed rhyolite flow or sill located at the head of Cody and Spruce creeks and one metamorphosed dike(?) located between Spruce and California creeks. White- to light gray- to light yellow-brown-weathering, with pale gray to pale greenish-gray color laminations (possible flow banding). Typically forms rounded hills of loose, fissile chips, but near the head of Spruce Creek, forms prominent outcrops that exhibit isoclinal folding of laminations. In thin section, composed of an aphanitic to finely granular mixture of quartz and feldspar, some of which may exhibit relict spherulitic texture. Phenocrysts of quartz are very rare. Weight percent CIPW normative composition is granite (rhyolitic texture). Typically has $\mathrm{Nb}+\mathrm{Y}>50 \mathrm{ppm}$ and $\mathrm{TiO}_{2}<0.3$ ppm. Major- and minor-oxide and trace-element analyses indicate the aphyric metarhyolite formed in a within-plate, extensional tectonic setting (fig. 7). Also contains rare, blocky, laminated pieces of bright red- and white-colored, banded, hematite-bearing, granular quartzite (jasperoid). Magnetic susceptibility is low $\left(0.00-0.11\right.$, averaging $\left.0.04 \times 10^{-3} \mathrm{SI}\right)$. Topographically overlies units Daw and interfoliated Dgq. Age is based on a trace-element-indicated tectonic setting similar to, and loose spatial association with, units Dg and Dr.

Db METABASITE (Devonian)—Carbonate-altered, metamorphosed mafic flows, sills, dikes, and (or) tuff. Primarily gray and green colored, but also brown and black. Metabasite is aphanitic to medium-grained (rarely coarse-grained), locally banded and laminated, and foliated. Outcrops are platy-breaking to massive. Primary igneous textures are erased by recrystallization and alteration. Mineral composition varies widely, but chemical composition suggests a mafic parent (high $\mathrm{TiO}_{2}$ and $\mathrm{MgO}$ ). Where metamorphosed but not carbonate-altered, major element composition is clearly basaltic; mineralogy is 30-50 percent chlorite, $20-30$ percent albite, $10-20$ percent clinozoisite, $<10$ percent carbonate, $<10$ percent quartz, and $1-2$ percent rutile + sphene + magnetite. Where carbonate-altered but not metasomatized, composition is $15-55$ percent carbonate, $<35$ percent chlorite, $<30$ percent albite, $<25$ percent white mica, $<15$ percent 
quartz, and accessory rutile, ilmenite, magnetite, and other opaque minerals. Due to its high carbonate content, metabasite is the preferred ore host at the Liberty Bell Mine. Where variably metasomatized and hornfelsed in the general mine area, composition is $<95$ percent tremolite, $<70$ percent biotite/ phlogopite, $<67$ percent calcite, $<60$ percent black to dark green chlorite, $<60$ percent white mica, $<60$ percent pyrophyllite, $<45$ percent actinolite, $<40$ percent plagioclase, $<40$ percent quartz, $<30$ percent clinopyroxene (diopside?), $<25$ tourmaline (brown- and green-gray-zoned), lesser epidote, clinozoisite, and accessory rutile, sphene, zircon, monazite, magnetite, ilmenite, and other opaque minerals. Ore minerals include arsenopyrite, pyrite, chalcopyrite, and pyrrhotite. Locally contains pyrrhotite-arsenopyrite-actinolite-calcite veins that cross-cut and subparallel foliation. Unit is rarely carbonaceous; a portion of the calcareous material may originally have had a sedimentary, instead of a mafic igneous, protolith. Magnetic susceptibility is moderate to high (0.0-5.92, averaging $\left.0.63 \times 10^{-3} \mathrm{SI}\right)$, primarily reflecting the pyrrhotite content. Major- and minor-oxide and trace-element analyses indicate the metabasite is alkalic and formed in a within-plate, extensional tectonic setting (fig. 7). Equivalent to the “Eva Creek phyllite” (Freeman and others, 1987) and possibly the chloritic schist of the Moose Creek Member of the Totatlanika Schist (Wahrhaftig, 1968). In the map area, the longest, continuous metabasite body is $2.5 \mathrm{~km}$ and the thickest is at least $300 \mathrm{~m}$. Spatially associated and interfoliated with units Dgq, Dq, Dr, and Dg such that the group forms a laterally extensive E-W subunit, suggesting stratigraphic significance. This grouping is essentially the Liberty Bell Mine sequence (Freeman and others, 1987). Metabasite is found within these units and unit Daw, and is the mafic portion of the bimodal suite of alkalic, igneous rocks. Where spatial extent is unknown, locations are marked with a symbol (see 'Map Symbols,' sheet RI 2006-2). Age is based on a trace-element-indicated tectonic setting similar to, and spatial association with, units Dg and Dr.

Daw ARKOSIC METAWACKE (Devonian)_Fine- to medium-grained with minor very fine- and coarsegrained, metamorphosed arkosic wacke and lesser feldspathic wacke. Also contains rare metamorphosed quartz wacke and fine-grained quartzite. Forms light green, gray, and white colored, commonly iron-stained, well-foliated and schistose outcrops; less commonly forms massive outcrops. Modal composition is 5-85 percent feldspar porphyroclasts (average 32 percent; average $2.2 \mathrm{~mm}$ in diameter), $<80$ percent clear, white, and smoky quartz porphyroclasts (average 17 percent; average $2 \mathrm{~mm}$ in diameter), and $<5$ percent lithics in very fine-grained $(<0.02 \mathrm{~mm}$ ) sericite \pm chlorite \pm biotite + quartz + feldspar matrix. Matrix is interpreted to be recrystallized mud. Accessory minerals include zircon, apatite, sphene, opaque minerals, and monazite. Metamorphosed lithic fragments include carbonaceous slate (mud ripup clasts?), polycrystalline quartz, chert, quartz-feldspar amalgams, and rare scheelite and garnet. Exhibits crystal sorting (bedding?). Although a large percentage of the porphyroclasts are rounded, shattered, and (or) sheared along foliation, occasional euhedral to sub-euhedral porphyroclasts, quartz embayments, and a homogeneous quartz + feldspar clast composition suggest the sediments are derived from felsic igneous rocks. Typically has $\mathrm{Y}+\mathrm{Nb}<50 \mathrm{ppm}$ (fig. 6) and $\mathrm{TiO}_{2}>0.3$ ppm. Locally contains disseminated arsenopyrite and pyrite, scorodite and stibiconite staining, and quartz \pm tourmaline veins up to $5 \mathrm{~cm}$ thick. Magnetic susceptibility is low (0.0-0.92, averaging $\left.0.10 \times 10^{-3} \mathrm{SI}\right)$; higher values are from hornfelsed samples. Except for the megacrystic variety of Dg, interfoliated units Db, Dg, Dq, Dr, Dar, and Dgq decrease in abundance to the north toward the topographic top of the unit. Unit is at least $900 \mathrm{~m}$ thick in Last Chance Creek, located $18 \mathrm{~km}$ southeast of the map area (Wahrhaftig, 1968). Equivalent to the "Lower tuffite sequence" in the Liberty Bell Mine sequence (Freeman and others, 1987) and quartz-orthoclase-sericite schist from the California Creek Member of the Totatlanika Schist (Wahrhaftig, 1970c). Age is assumed to be Devonian; unit is intruded by Devonian-aged meta-igneous units Dg and Dr and stratigraphically(?) overlain by the Devonian Chute Creek Member of the Totatlanika Schist (fig. 5; Dusel-Bacon and others, 2004).

Dq QUARTZITE AND METAPELITE (Devonian) - Very fine- to fine-grained, sucrosic quartzite and metapelite. Orange-weathered, white-colored outcrops are either platy-breaking or hard and massive depending on the mica content of the rock. Modal composition is 50-97 percent quartz (grains up to 0.1 mm in diameter), 3-50 percent white mica, 5(?) percent feldspar, and 2 percent calcite. Commonly contains $<2$ percent disseminated pyrrhotite, $<5$ percent pyrite, and lesser tourmaline, arsenopyrite, and phlogopite/biotite in wispy bands and laminations. This unit only appears in the hornfelsed zone. Magnetic susceptibility is moderate to high (0.0-4.0, averaging $\left.0.45 \times 10^{-3} \mathrm{SI}\right)$, and variable due to the 
amount of unoxidized pyrrhotite in the rock. In Little Moose Creek, unit is at least $350 \mathrm{~m}$ thick. Equivalent to the "Hangingwall slatey phyllite" in the Liberty Bell Mine sequence (Freeman and others, 1987) and slate within the California Creek and Moose Creek(?) members of the Totatlanika Schist (Wahrhaftig, 1968). Quartzite and metapelite is found interfoliated with units Dgq, Daw, Dr, Dg, and Db. Age is based on spatial association with these Devonian units.

Dgq GRAPHITIC QUARTZITE (Devonian) — Very fine- to fine-grained, sucrosic, foliated graphitic quartzite. Gray- to black-colored outcrops are fissile to blocky-breaking. Composition is $<90$ percent quartz, $<36$ percent white mica, $<10$ percent graphite, with accessory apatite, zircon, and opaque minerals. Graphite occurs disseminated throughout the rock, in lenses, sooty partings, and rare nodules. Locally hornfelsed and bleached to light gray and white, and commonly iron-oxide stained. Hornfels contains up to 30 percent pyrrhotite and occasionally quartz-tourmaline-biotite/phlogopite veins. Intense mineralization is expressed as brecciated quartz veins with iron oxide, scorodite, and arsenopyrite cement. Magnetic susceptibility is generally low (0.0-1.0, averaging $\left.0.1 \times 10^{-3} \mathrm{SI}\right)$; hornfelsed samples containing pyrrhotite have magnetic susceptibilities up to $2.53 \times 10^{-3} \mathrm{SI}$. In the map area, unit ranges from 3-m-thick lenses to approximately 700 -m-thick sections, and decreases in thickness topographically (and stratigraphically?) up-section. Unit found interfoliated with all of the Devonian units in the map area, and age of unit is also assumed to be Devonian. Equivalent to "Graphitic (Footwall) phyllite" of the mine sequence (Freeman and others, 1987) and graphitic quartzite and schist in the California Creek and Moose Creek Members of the Totatlanika Schist and the Keevy Peak Formation (Wahrhaftig, 1968).

Dqw QUARTZ METAWACKE AND META-ARENITE (Devonian)—Very fine- to medium-grained, rarely coarse-grained, metamorphosed quartz wacke and arenite, and minor feldspathic wacke. Light gray and light gray-green colored, hard and massive to platy-breaking, and foliated in outcrop. Modal composition is 14-80 percent quartz porphyroclasts (mono- and polycrystalline), 0-25 percent feldspar porphyroclasts (varying amounts of K-feldspar and plagioclase/albite), 0-10 percent chert or chalcedony grains, and a matrix of 5-50 percent white mica, $0-25$ percent chlorite, and 20-35 percent very fine-grained quartz $(<0.02$ $\mathrm{mm}$ ). Accessory minerals include tourmaline, rutile, ilmenite, graphite, pyrite, and zircon. Subangular to rounded, $0.2-3.0 \mathrm{~mm}$ grains are common. Magnetic susceptibility is low $\left(0.0-0.5\right.$, averaging $\left.0.09 \times 10^{-3} \mathrm{SI}\right)$. In the map area, unit is at least $600 \mathrm{~m}$ thick. Topographically underlies California Creek Member and units Dg and Dr, mapped as the Moose Creek Member of the Totatlanika Schist (Wahrhaftig, 1970c). Equivalent to "arkosic gritlike schist" of Keevy Peak Formation (Wahrhaftig, 1970c). Age is presumed to be Devonian; unit is intruded by meta-igneous unit Dr, stratigraphically(?) overlain by unit Daw, and stratigraphically(?) underlain by Devonian(?) Healy Schist (Birch Creek Schist of former usage; Wahrhaftig, 1968; Newberry and others, 1997; Dusel-Bacon and others, 2004) (fig. 5).

\section{ACKNOWLEDGMENTS}

This project is part of the Alaska Airborne Geophysi$\mathrm{cal} /$ Geological Mineral Inventory Program funded by the Alaska State Legislature and managed by State of Alaska, Department of Natural Resources (DNR), Division of Geological \& Geophysical Surveys (DGGS). Partial funding for the geologic mapping was also provided by the U.S. Geological Survey, National Cooperative Geologic Mapping Program, under STATEMAP award number 05HQAG0025, and the State's General Fund. Partial funding for the proximate and ultimate coal analyses presented in tables F1 and F2 (appendix F) was provided through a grant from the U.S. Geological Survey's National Coal Resource Data System. The views and conclusions contained in this document are those of the authors and should not be interpreted as necessarily representing the official policies, either expressed or implied, of the U.S. Government.
The following people are recognized for their various contributions to this map.

Quaternary: De Anne S.P. Stevens (DGGS) for geologic discussions and sharing preliminary data from the surficial-geologic study.

Tertiary: Rocky R. Reifenstuhl (DGGS) and Kenneth P. Helmold (Alaska Division of Oil \& Gas) for discussions regarding grain mounts and point counting; Paul J. McCarthy (University of Alaska Fairbanks) for discussions about Tertiary sample processing; Robert L. Ravn (the IRF group, inc.) for assistance interpreting pollen data; Paul A. Metz (University of Alaska Fairbanks) for the use of his sedimentary lab; Paul W. Layer (University of Alaska Fairbanks) for providing an ${ }^{40} \mathrm{Ar} /{ }^{39} \mathrm{Ar}$ analysis of a fused sedimentary rock sample; Alan Renshaw (Usibelli Coal Mine) for hosting a field trip through 
the Tertiary section; James G. Clough (DGGS) for providing coal energy analyses; and Ronald $\mathrm{H}$. Affolter (USGS-Denver), Gary D. Stricker (USGSDenver), and Jamey D. McCord (USGS-Energy Lab) for providing geochemical analyses of coal ash.

Pre-Tertiary and mineralization: Katharine F. Bull (DGGS) for assistance distinguishing greenschist facies metavolcanic and volcanic textures; Erik W. Hansen for facilitating review of industry data and maps; John T. Galey, Jr. for providing industry data and thoughts about the mineralizing system; Richard R. Lessard (DGGS) for compilation of industry data and compiling geochemical data release RDF 2005-5; Christopher J. Nye (DGGS/Alaska Volcano Observatory) for providing an Ar-Ar age; the Ruppert family for donating a placer gold sample from Little Moose Creek; and Ray “Mudd” Lyle and Jim Roland for Moose Creek lode samples.

Other: David L. LePain (DGGS) and Richard W. Flanders for their thoughtful, technical reviews; Paula K. Davis (DGGS) for her editorial review; Wesley K. Wallace (University of Alaska Fairbanks) and Robert F. Swenson (DGGS) for structural geology discussions, Laurel E. Burns (DGGS) for assistance with interpretation of geophysical and statistical data; student interns William A. Smith, II, Benjamin D. Christian, and Brian A. McNulty for their assistance on various parts of this project; Robin L. Smith (DGGS) for help with point counting and final map preparation; Mike Franger (Alaska Mental Health Trust Land Office) for providing access to Mental Health lands; Jim Roland, Wallace O. Turner, II, and the Blair family for allowing us access to industry data from their property; and the Blair family (Boothill Gold, Inc.) for letting us stay at the Eva Creek camp.

This publication is dedicated to the memory of Boyd J. Blair, owner of the Liberty Bell Mine from 1964 until his death in 2004.

\section{REFERENCES CITED}

$\overline{\text { Albanese, M.D., and Turner, D.L., } 1980,{ }^{40} \mathrm{~K}-{ }^{40} \mathrm{Ar} \text { ages }}$ from rhyolite of Sugar Loaf Mountain, central Alaska Range: Implications for offset along the Hines Creek strand of the Denali Fault system, in DGGS Staff, Short Notes on Alaskan Geology, 1979-1980: Alaska Division of Geological \& Geophysical Surveys Geologic Report 63B, p. 7-10.

Athey, J.E., Werdon, M.B., Newberry, R.J., Szumigala, D.J., Freeman, L.K., and Lessard, R.R., 2005, Majoroxide, minor-oxide, and trace-element geochemical data from rocks collected in the Liberty Bell area, Fairbanks A-4 Quadrangle, Alaska in 2005: Alaska
Division of Geological \& Geophysical Surveys Raw Data File 2005-5, 29 p.

Bemis, S.P., 2004, Neotectonic framework of the northcentral Alaska Range foothills: Fairbanks, University of Alaska, Master of Science thesis, 142 p.

Bidwell, Gerry, 1994, 1994 Exploration Program, Liberty Bell Property, Bonnifield Mining District, Fairbanks A-4 Quadrangle, T10S R6-7W, Alaska, USA: Noranda Exploration Company, 17 p., appendices I-III.

Buffler, R.T., and Triplehorn, D.M., 1976, Depositional environments of the Tertiary coal-bearing group, central Alaska, in Miller, T.P., ed., Recent and ancient sedimentary environments in Alaska, Proceedings of Symposium, April 2-4, Anchorage: Anchorage, Alaska Geological Society, p. H1-H10.

Bundtzen, T.K., 1986, Prospect examination of a goldtungsten placer deposit at Alder Creek, Vinasale Mountain area, western Alaska: Alaska Division of Geological \& Geophysical Surveys Public Data File 86-15, $10 \mathrm{p}$.

Burns, L.E., Fugro Airborne Surveys, and Stevens Exploration Management Corp., 2002, Plot files of the airborne geophysical survey data of the Liberty Bell area, western Bonnifield mining district, central Alaska: Alaska Division of Geological \& Geophysical Surveys, Geophysical Report (GPR) 2002-06, 1 CD-ROM.

Capps, S.R., 1912, The Bonnifield region, Alaska: U.S. Geological Survey Bulletin 501, 64 p.

Davis, J.C., 1986, Statistics and data analysis in geology, 2nd ed.: John Wiley and Sons, Inc., 646 p.

Decker, J.E., 1985, Sandstone model analysis procedure: Alaska Division of Geological \& Geophysical Surveys Public Data File 85-3, 38 p.

DGGS, 1994, Unpublished geologic mapping of Liberty Bell Mine area (Reifenstuhl, R.R., Werdon, M.B., and Wiltse, M.A.).

Dickinson, W.R., Beard, L.S., Brakenridge, G.R., Erjavec, J.L., Ferguson, R.C., Inman, K.F., Knepp, R.A., Lindberg, F.A., and Ryberg, P.T., 1983, Provenance of North American Phanerozoic sandstones in relation to tectonic setting: Geological Society of America Bulletin, v. 94, no. 2, p. 222-235.

Dusel-Bacon, Cynthia, Wooden, J.L., and Hopkins, M.J., 2004, U-Pb zircon and geochemical evidence for bimodal mid-Paleozoic magmatism and syngenetic base-metal mineralization in the Yukon-Tanana terrane, Alaska: Geological Society of America Bulletin, v. 116, no. 7, p. 989-1,015.

Ellis, William, Hawley, C.C., and Dashevsky, Samuel, 2004, Alaska Resource Data File, Mount Hayes Quadrangle, Alaska: U.S. Geological Survey Open-File Report 2004-1266. 
Freeman, C.J., and Schaefer, Janet, 2001, Alaska Resource Data File, Fairbanks Quadrangle: U.S. Geological Survey Open-File Report 01-0426, 355 p.

Freeman, L.K., Hanneman, N.L., and Flanders, R.W., 1987, Liberty Bell Joint Venture Report of 1987 Exploration: Resource Associates of Alaska, Inc., v. I, II, and IV.

Galey, J.T., Jr., Hahn, Raimundo, and Duncan, W.M., 1993, 1991 Exploration Program, Liberty Bell Project, Bonnifield mining district, Nenana recording district, Alaska: AMAX Gold, Inc., 39 p., appendices A-E.

Gilbert, W.G., and Bundtzen, T.K., 1979, Mid-Paleozoic tectonics, volcanism, and mineralization in the northcentral Alaska Range: Geological Society of Alaska Symposium 1977, p. F1-F22.

Ingersoll, R.V., Bullard, T.F., Ford, R.L., Grimm, J.P., Pickle, J.D., and Sares, S.W., 1984, The effect of grain size on detrital modes: A test of the Gazzi-Dickinson point-counting method: Journal of Sedimentary Petrology, v. 54, p. 103-116.

Irvine, T.N., and Baragar, W.R.A., 1971, A guide to the chemical classification of the common volcanic rocks: Canadian Journal of Earth Sciences, v. 8, p. 523-548.

Lanphere, M.A., and Dalrymple, G.B., 2000, First-principles calibration of ${ }^{38} \mathrm{Ar}$ tracers: Implications for the ages of ${ }^{40} \mathrm{Ar} /{ }^{39} \mathrm{Ar}$ fluence monitors: U.S. Geological Survey Professional Paper 1621, 10 p.

Layer, P.W., 2000, ${ }^{40}$ Argon $/{ }^{39}$ Argon age of the El'gygytgyn impact event, Chukotka, Russia: Meteoritics and Planetary Science, v. 35, p. 591-599.

Layer, P.W., Hall, C.M., and York, Derek, 1987, The derivation of ${ }^{40} \mathrm{Ar} /{ }^{39} \mathrm{Ar}$ age spectra of single grains of hornblende and biotite by laser step heating: Geophysical Research Letters, v. 14, p. 757-760.

Leopold, E.B., and Liu, Gengwu, 1994, A long pollen sequence of Neogene age, Alaska Range: Quaternary International, v. 22/23, p. 103-140.

McCoy, D., Newberry, R.J., Layer, P.W., DiMarchi, J.J., Bakke, A., Masterman, J.S., and Minehanne, D.L., 1997, Plutonic-related gold deposits of Interior Alaska, in Goldfarb, R.J., and Miller, L.D., eds., Mineral deposits of Alaska: Economic Geology Monograph 9, p. 191-241.

McDougall, Ian and Harrison, T.M., 1999, Geochronology and Thermochronology by the ${ }^{40} \mathrm{Ar} /{ }^{39} \mathrm{Ar}$ method, 2nd ed., Oxford University Press: New York, $269 \mathrm{p}$.

Meschede, Martin, 1986, A method of discriminating between different types of mid-ocean ridge basalts and continental tholeiites with the $\mathrm{Nb}-\mathrm{Zr}-\mathrm{Y}$ diagram: Chemical Geology, v. 56, p. 207-218.

Newberry, R.J., Crafford, T.C., Newkirk, S.R., Young, L.E., Nelson, S.W., and Duke, N.A., 1997, Volcanogenic massive sulfide deposits of Alaska: Economic Geology Monograph 9, p. 120-150.

Pearce, J.A., Harris, N.B.W., and Tindle, A.G., 1984, Trace element discrimination diagrams for the tectonic interpretation of granitic rocks: Journal of Petrology, v. 25, p. 956-983.

Pettijohn, F.J., Potter, P.E., and Siever, Raymond, 1987, Sand and sandstone, 2nd ed.: New York, SpringerVerlag, $553 \mathrm{p}$.

Plafker, George, Naeser, C.W., Zimmermann, R.A., Lull, J.S., and Hudson, Travis, 1992, Cenozoic uplift history of the Mount McKinley area in the central Alaska Range based on fission-track dating: U.S. Geological Survey Bulletin 2041, p. 202-212.

Puchner, C.C., and Freeman, L.K., 1988, Summary of Liberty Bell area prospects and recommendations for future exploration: NERCO Exploration Company internal correspondence.

Ridgway, K.D., Trop, J.M., and Jones, D.E., 1999, Petrology and provenance of the Neogene Usibelli Group and Nenana Gravel: Implications for the denudation history of the central Alaska Range: Journal of Sedimentary Research, v. 69, no. 6, p. 1,262-1,275.

Ridgway, K.D., Trop, J.M., Nokleberg, W.J., Davidson, C.M., and Eastham, K.R., 2002, Mesozoic and Cenozoic tectonics of the eastern and central Alaska Range: Progressive basin development and deformation in a suture zone: Geological Society of America Bulletin, v. 114, no. 12, p. 1480-1504.

Samson, S.D., and Alexander, E.C., 1987, Calibration of the interlaboratory ${ }^{40} \mathrm{Ar} /{ }^{39} \mathrm{Ar}$ dating standard, MMhb1: Chemical Geology, v. 66, p. 27-34.

Stanley, R.G., Flores, R.M., and Wiley, T.J., 1992, Fluvial facies architecture in the Tertiary Usibelli Group of Suntrana, central Alaska, in Bradley, D.C., and Ford, A.B., eds., Geologic studies in Alaska by the U.S. Geological Survey, 1990: U.S. Geological Survey Bulletin 1999, p. 204-211.

Steiger, R.H., and Jaeger, Emilie, 1977, Subcommission on geochronology: Convention on the use of decay constants in geo and cosmochronology: Earth and Planet Science Letters, v. 36, p. 359-362.

Szumigala, D.J., and Hughes, R.A., 2005, Alaska’s Mineral Industry 2004: Alaska Division of Geological \& Geophysical Surveys, Special Report 59, 75 p.

Thoms, E.E., 2000, Late Cenozoic unroofing sequence and foreland basin development of the central Alaska Range: Implications from the Nenana Gravel: Fairbanks, University of Alaska, Master of Science thesis, $215 \mathrm{p}$.

Triplehorn, D.M., 1976, Clay mineralogy and petrology of the coal-bearing group near Healy: Alaska Division of Geological \& Geophysical Surveys Geologic Report 52, 14 p. 
Van Der Plas, L., and Tobi, A.C., 1965, A chart for judging the reliability of point counting results: American Journal of Science, v. 263, p. 87-90.

Wahrhaftig, Clyde, 1968, Schists of the central Alaska Range: U.S. Geological Survey Bulletin 1254-E, 22 p.

Wahrhaftig, Clyde, 1970a, Geologic map of the Fairbanks A-2 quadrangle, Alaska: U.S. Geological Survey Geologic Quadrangle Map GQ-808, 1 sheet, scale 1:63,360.

Wahrhaftig, Clyde, 1970b, Geologic map of the Fairbanks A-3 quadrangle, Alaska: U.S. Geological Survey Geologic Quadrangle Map GQ-809, 1 sheet, scale 1:63,360.

Wahrhaftig, Clyde, 1970c, Geologic Map of the Fairbanks A-4 quadrangle, Alaska: U.S. Geological Survey Geologic Quadrangle Map GQ-810, 1 sheet, scale 1:63,360.

Wahrhaftig, Clyde, 1970d, Geologic map of the Healy D-2 quadrangle, Alaska: U.S. Geological Survey Geologic Quadrangle Map GQ-804, 1 sheet, scale 1:63,360.

Wahrhaftig, Clyde, 1970e, Geologic map of the Healy D-3 quadrangle, Alaska: U.S. Geological Survey Geologic Quadrangle Map GQ-805, 1 sheet, scale 1:63,360.

Wahrhaftig, Clyde, 1970f, Geologic Map of the Healy D-4 quadrangle, Alaska: U.S. Geological Survey Geologic Quadrangle Map GQ-806, 1 sheet, scale 1:63,360.

Wahrhaftig, Clyde, 1987, The Cenozoic section at Suntrana Creek, in Hill, M.L., ed., Geological Society of America, Cordilleran Section, Centennial Field Guide, v. 1, p. 445-450.

Wahrhaftig, Clyde, Wolfe, J.A., Leopold, E.B., and Lanphere, M.A., 1969, The coal-bearing group in the Nenana Coal Field, Alaska: U.S. Geological Survey Bulletin 1274-D, p. D1-D30.
Williams, Howel, Turner, F.J., and Gilbert, C.M., 1982, Petrography, an introduction to rocks in thin section, 2nd ed.: San Francisco, CA, W.H. Freeman and Company, $626 \mathrm{p}$.

Wolfe, J.A., and Tanai, Toshimasa, 1980, The Miocene Seldovia Point flora from the Kenai Group, Alaska: U.S. Geological Survey Professional Paper 1105, 52 p.

Wolfe, J.A., and Tanai, Toshimasa, 1987, Systematics, phylogeny, and distribution of Acer (Maples) in the Cenozoic of western North America: Hokkaido University Faculty of Science Journal, ser. 4, v. 22, p. 1-246.

Wood, G.H., Kehn, T.M., Carter, M.D., and Culbertson, W.C., 1983, Coal resource classification system of the U.S. Geological Survey: U.S. Geological Survey Circular 891, 65 p.

Yesilyurt, Suleyman, 1994, Geology, geochemistry, and mineralization of the Liberty Bell gold mine area, Alaska: Oregon State University, unpublished Master of Science thesis, 189 p., 1 plate.

Yesilyurt, Suleyman, 1996, Geology, geochemistry, and mineralization of the Liberty Bell gold mine area, Alaska, in Coyner, A.R., and Fahey, P.L., eds., Geology and Ore Deposits of the American Cordillera: Symposium Proceedings, Reno/Sparks, Nevada, April 1995, p. 1,281-1,316.

York, Derek, Hall, C.M., Yanase, Yotaro, Hanes, J.A., and Kenyon, W.J., 1981, ${ }^{40} \mathrm{Ar} /{ }^{39} \mathrm{Ar}$ dating of terrestrial minerals with a continuous laser: Geophysical Research Letters, v. 8, p. 1,136-1,138. 



\section{Appendix A}

\section{Geochemical analyses of Paleozoic samples}

Gold-bearing samples from Athey and others (2005) were re-analyzed in order to obtain concentrations of certain elements that exceeded the upper detection limits, were less than the lower detection limits, or were not analyzed by inductively coupled plasma-atomic emission spectroscopy (ICP-AES; table A1). Analyses were performed by ALS Chemex. Rock samples were already crushed and pulverized using the techniques described in Athey and others (2005). Trace-element analyses were performed on a 200-gram split. Most elements were analyzed by inductively coupled plasma with mass spectroscopy or atomic emission spectroscopy (ICP-MS/AES) after four-acid, near-total digestion. This method of digestion is possibly incomplete for some elements and may result in lower analytical results for certain elements. A complete listing of analytical methods, lower and upper detection limits, and the elements that may be affected by incomplete digestion are included in table A2.

Major- and minor-oxide and trace-element compositions in table A3 were performed by X-ray fluorescence at the University of Alaska Fairbanks on polished slabs and are necessarily approximations to the true compositions. Fine-grained rocks (maximum grain size $<1 \mathrm{~mm}$ ) were cut to fit in 27-mmdiameter sample holders; coarser grained rocks (maximum grain size $<3 \mathrm{~mm}$ ) were analyzed in 37 $\mathrm{mm}$-diameter holders. Analyses were standardized using well-characterized natural fine-grained rock and pure mineral standards as well as conventional pressed pellets of international rock standards.

Because volatile components were not measured and rocks were of varying porosities, the analyses were normalized to 100 percent totals. In the vast majority of cases the original analyses yielded totals of approximately 95 to 102 weight percent. Comparison between these analyses and those produced on the same rocks by conventional pressed pellet (trace elements) and fused disk (major elements) techniques indicates that major-oxide concentrations are most likely within 10 percent of the 'true' concentrations; trace-element concentrations are typically within 20 percent of true concentrations. 
This page has intentionally been left blank. 
Table A1. Location, description, and concentration of trace elements for samples collected in the Liberty Bell area of the Fairbanks A-4 Quadrangle, Alaska. Rock names in ( ) are derived from geochemical data and rock textures in hand samples. Location coordinates were collected using a hand-held GPS unit (no differential correction was applied), and coordinates are presented in latitude and longitude (based on the NAD27 Alaska datum) and in UTM coordinates (based on the Clark 1866 spheroid, NAD27 datum, UTM zone 6 projection). Note: $-=$ not analyzed.

\begin{tabular}{|c|c|c|c|}
\hline Sample & & & \\
\hline Number & Latitude & Longitude & UTM Easting \\
\hline 05JEA49A & 64.0732 & -148.8636 & 409092 \\
\hline 05LF53B & 64.0689 & -148.6453 & 419726 \\
\hline 05LF61B & 64.0707 & -148.6042 & 421738 \\
\hline 05LF231A & 64.0585 & -148.8577 & 409330 \\
\hline 05MBW224A & 64.0494 & -148.5785 & 422929 \\
\hline 05MBW298A & 64.0643 & -148.7233 & 415908 \\
\hline 05MBW374A & 64.0528 & -148.9624 & 404205 \\
\hline 05JEA121B & 64.0856 & -148.6123 & 421384 \\
\hline 05LF141B & 64.0660 & -148.5014 & 426738 \\
\hline 05LF77A & 64.0792 & -148.5820 & 422844 \\
\hline 05LF78A & 64.0798 & -148.5817 & 422860 \\
\hline 05LF79B & 64.0832 & -148.5802 & 422944 \\
\hline 05LF228A & 64.0556 & -148.8664 & 408900 \\
\hline 05MBW50A & 64.0475 & -148.9273 & 405897 \\
\hline & & & \\
\hline
\end{tabular}

05MBW292A $\quad 64.0564 \quad-148.7276 \quad 415672$

05MBW296B $\quad 64.0606 \quad-148.7236 \quad 415883$

05MBW303A $\quad 64.0671 \quad-148.7230 \quad 415930$

05MBW363A $\quad 64.0566 \quad-148.9543 \quad 404610$

05MBW407A $64.0532 \quad-148.7248$

05Z108B
$64.0655-148.6579$

\section{Description}

7106300

and scorodite staining. Prospect pits.

7105536 Quartz-tourmaline vein; 10 percent of regolith, $2-10 \mathrm{~cm}$ pieces in 10-m-wide zone, contains 5-40 percent red-brown/limonite coated boxwork, with no relict sulfides.

7105685 Granite; porphyritic, strongly altered, sericitized, relict fine grain textured quartz, and fractures with veinlets of green-yellow and gray boxwork quartz.

7104660 Skarn; (skarn), medium- to coarse-grained, random-oriented actinolite with interstitial plagioclase, 1-4 percent pyrrhotite, 2-3 percent chalcopyrite, 1 percent arsenopyrite. Industry map unit "Mesozoic meta-gabbro."

7103278 Meta-ash(?); gray colored, yellow-, orange-, and gray-weathering foliated, aphanitic to very finely granular, finely color laminated, with Fe-oxide and possibly stibiconite(?) coatings. Contains disseminated, empty vugs (up to $0.2 \mathrm{~mm}$ in diameter) that may have contained sulfides.

7105119 Metarhyolite; brecciated, sheared, and \pm quartz-veined. Quartz veins \pm disseminated vugs, \pm coated with scorodite.

7104179 Hornfelsed meta-argillite; white, foliated, very finely granular, cut by veins (up to 1 inch wide) and veinlets containing various combinations of white crystalline quartz, sprays and mats of very tiny, acicular, brown- to forest green-colored tourmaline crystals, and disseminated Fe-oxides (after pyrite(?) cubes).

7107352 Quartz vein; with green mineral (epidote?) and weathered pyrite.

7105041 Quartz breccia vein; angular blocks of quartz in matrix and with fractures filled with massive stibnite, with possible arsenopyrite and galena. Grab sample of 0.4-m-thick zone in larger quartz vein.

7106607 Quartz vein; 5-cm-thick, drusy quartz, with 30 percent arsenopyrite infill.

7106673 Quartz vein; 2- to 5-cm-wide, brecciated, with 75 percent graywhite quartz, 5-20 percent arsenopyrite infill, 5 percent green tourmaline, 5 percent boxwork, and 0-20 percent green-blue tourmaline, 5 percent boxwork,
cryptocrystalline infill - unknown.

7107050 Fault breccia; bleached, with quartz-arsenopyrite-unknown-gray mineral vein, 0.6-m-wide chip sample.

7104351 Vein; 3- to 5-cm-wide, in white sericite altered felsic rock, with quartz, tourmaline, and arsenopyrite from push-pile in "northwest copper zone," Liberty Bell property.

7103538 Intermediate composition dike; (granodiorite), grayish-green, brown weathering, porphyritic, with biotite and quartz phenocryst. Contains disseminated pyrite and arsenopyrite.

7104098 Quartz vein; small prospecting pit containing light yellow-stained quartz vein material, dark-brown Fe-oxide and quartz-crystal breccias, and intergrown quartz and Fe-oxide. Scattered vein material composed of massive, dark-gray stibnite, and cubic pyrite. Mineralized fault zone trends approximately 155 degrees (azimuth).

7104245 Fault gouge; 1 - to 2-inch-wide fault zone that widens out to approximately 1 foot wide, cutting foliation in phyllite. Fault is filled with brecciated, angular wall rock fragments, rock flour, and quartz veins with finely disseminated arsenopyrite. Fault strikes 309 degrees (azimuth) and dips 30 degrees.

7104714 Quartz vein; from shear zone up to 3 inches wide. Sample contains light gray to clear quartz with disseminated crystals $(\leq 3$ $\mathrm{mm}$ ) of arsenopyrite up to 40 percent of vein but generally $<20$ percent. Shear zone strikes 258 degrees (azimuth) and dips 38 degrees.

7105437 Shear zone; varies from 1 to 3 feet wide, with peripheral quartz + iron oxide veins extending off of the main shear zone. Heavily Feoxide- and yellow-stained veins contain quartz, pyrite, and arsenopyrite, with dark brownish-green tourmaline sprays, chlorite(?), secondary Fe-oxide, and scorodite. Shear zones strike 310 degrees (azimuth) and dip 60 degrees.

7104593 Quartz vein; Loose rubble of hornfelsed, carbonaceous metasedimentary rocks that have been intruded and hornfelsed by a fine-grained, equigranular, granite dike, which is cut by quartz veins. Sampled heavily Fe-oxide-coated, gray, massive, granular quartz vein material that is intergrown with very fine-grained quartz vein material that is intergrown with very fine-grained inches long.

4157997103886 Quartz vein; abundant Fe-oxide coating, yellow oxides (scorodite) and local $\leq 1$ percent pyrite in hornfelsed phyllite.

7105167 Quartz-tourmaline-arsenopyrite-Fe-oxide vein; dark brown and orange, gossanous, Fe-oxide stained, with patches of pale yellow staining and clots of discontinuous patches of very fine grained arsenopyrite (2-3 percent up to 7 percent).

$\mathrm{Ag}$

20.8


Table A1. Location, description, and concentration of trace elements for samples collected in the Liberty Bell area of the Fairbanks A-4 Quadrangle, Alaska. Rock names in ( ) are derived from geochemical data and rock textures in hand samples. Location coordinates were collected using a hand-held GPS unit (no differential correction was applied), and coordinates are presented in latitude and longitude (based on the NAD27 Alaska datum) and in UTM coordinates (based on the Clark 1866 spheroid, NAD27 datum, UTM zone 6 projection). Note: $-=$ not analyzed—continued.

\begin{tabular}{|c|c|c|c|c|c|c|c|c|c|c|c|c|c|c|c|c|c|c|c|c|c|}
\hline $\begin{array}{l}\text { Sample } \\
\text { Number }\end{array}$ & $\begin{array}{c}\mathrm{Ag} \\
\mathrm{ppm}\end{array}$ & $\begin{array}{l}\mathrm{Al} \\
\% \\
\end{array}$ & $\begin{array}{l}\text { As } \\
\mathrm{ppm}\end{array}$ & $\begin{array}{l}\text { As } \\
\%\end{array}$ & $\begin{array}{c}\mathrm{Ba} \\
\mathrm{ppm}\end{array}$ & $\begin{array}{c}\mathrm{Be} \\
\mathrm{ppm}\end{array}$ & $\begin{array}{c}\mathrm{Bi} \\
\mathrm{ppm}\end{array}$ & $\begin{array}{l}\mathrm{Ca} \\
\% \\
\end{array}$ & $\begin{array}{l}\mathrm{Cd} \\
\mathrm{ppm}\end{array}$ & $\begin{array}{c}\mathrm{Ce} \\
\mathrm{ppm}\end{array}$ & $\begin{array}{l}\text { Co } \\
\text { ppm }\end{array}$ & $\begin{array}{c}\mathrm{Cr} \\
\mathrm{ppm}\end{array}$ & $\begin{array}{l}\text { Cs } \\
\text { ppm }\end{array}$ & $\begin{array}{c}\mathrm{Cu} \\
\mathrm{ppm}\end{array}$ & $\begin{array}{l}\mathrm{Fe} \\
\%\end{array}$ & $\begin{array}{c}\mathrm{Ga} \\
\mathrm{ppm}\end{array}$ & $\begin{array}{c}\mathrm{Ge} \\
\mathrm{ppm}\end{array}$ & $\begin{array}{l}\mathrm{Hf} \\
\mathrm{ppm}\end{array}$ & $\begin{array}{l}\text { In } \\
\text { ppm }\end{array}$ & $\begin{array}{l}\mathrm{K} \\
\% \\
\end{array}$ & $\begin{array}{l}\text { La } \\
\text { ppm }\end{array}$ \\
\hline 05JEA49A & --- & 2.18 & 5450 & -- & 330 & 0.73 & 0.28 & 0.04 & 0.52 & 42.4 & 0.3 & 24 & 2.95 & 42.7 & 1.3 & 5.4 & $<0.05$ & 0.3 & 0.375 & 1.41 & 21.4 \\
\hline 05LF53B & --- & 4.06 & 224 & --- & 490 & 3.19 & 911 & 0.06 & 0.82 & 116 & 32.6 & 19 & 1.62 & 261 & 18.35 & 16.4 & 0.08 & 0.4 & 0.427 & 1 & 59.6 \\
\hline 05LF61B & --- & 7.29 & 915 & --- & 1930 & 3.21 & 2.33 & 0.01 & 0.17 & 61.4 & 0.6 & 7 & 9.9 & 40 & 2.81 & 21.7 & 0.06 & 4.1 & 0.296 & 4.94 & 33 \\
\hline 05LF231A & --- & 4.14 & 705 & --- & 110 & 3.65 & 41.9 & 7.36 & 3.04 & 26.8 & 4.3 & 41 & 3.27 & 169 & 7.29 & 18.6 & $<0.05$ & 2.2 & 0.258 & 0.07 & 12.6 \\
\hline 05MBW224A & --- & 0.67 & 50.7 & --- & 110 & 8.64 & 0.21 & 0.01 & 0.04 & 4.6 & 0.1 & 17 & 0.37 & 4.4 & 0.88 & 3.18 & $<0.05$ & 0.1 & 0.005 & 0.64 & 2.6 \\
\hline 05MBW298A & --- & 5.33 & 8940 & --- & 660 & 1.87 & 2.37 & 0.25 & $<0.02$ & 86.6 & 1.9 & 10 & 8.8 & 33.5 & 2.7 & 15.35 & 0.07 & 0.8 & 0.05 & 3.23 & 42.8 \\
\hline $5 \mathrm{MBW} 374 \mathrm{~A}$ & --- & 1.49 & 124.5 & --- & 220 & 0.95 & 72.5 & 0.05 & $<0.02$ & 16.55 & 0.4 & 92 & 0.99 & 20.1 & 0.88 & 7.8 & $<0.05$ & 0.9 & 0.06 & 0.09 & 8.5 \\
\hline
\end{tabular}

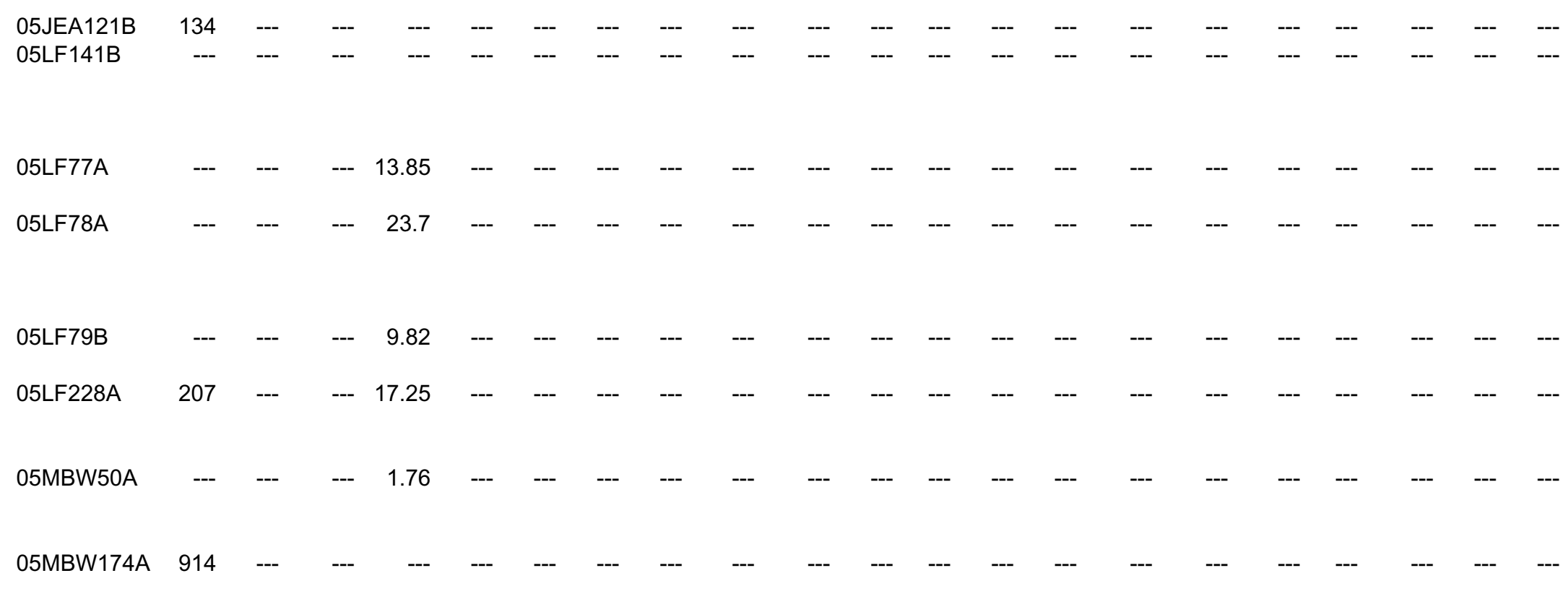

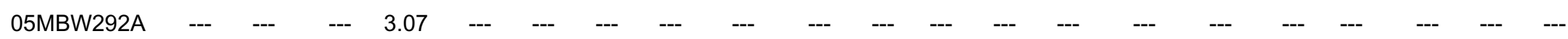

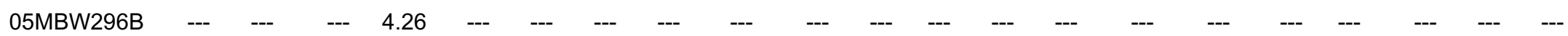

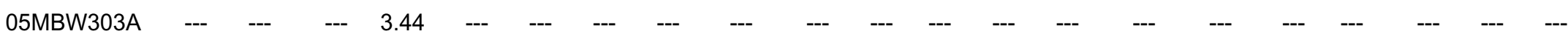

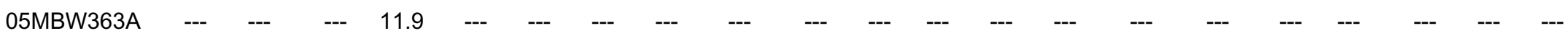

05MBW407A

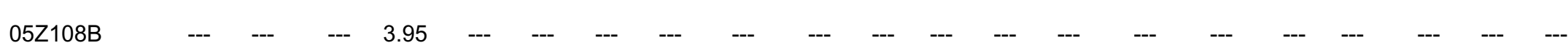


Table A1. Location, description, and concentration of trace elements for samples collected in the Liberty Bell area of the Fairbanks A-4 Quadrangle, Alaska. Rock names in ( ) are derived from geochemical data and rock textures in hand samples. Location coordinates were collected using a hand-held GPS unit (no differential correction was applied), and coordinates are presented in latitude and longitude (based on the NAD27 Alaska datum) and in UTM coordinates (based on the Clark 1866 spheroid, NAD27 datum, UTM zone 6 projection). Note: $-=$ not analyzed - continued.

\begin{tabular}{|c|c|c|c|c|c|c|c|c|c|c|c|c|c|c|c|c|c|c|c|c|c|}
\hline $\begin{array}{l}\text { Sample } \\
\text { Number }\end{array}$ & $\begin{array}{c}\mathrm{Li} \\
\mathrm{ppm}\end{array}$ & $\begin{array}{c}\mathrm{Mg} \\
\% \\
\end{array}$ & $\begin{array}{c}\text { Mn } \\
\text { ppm }\end{array}$ & $\begin{array}{c}\text { Mo } \\
\text { ppm }\end{array}$ & $\begin{array}{c}\mathrm{Na} \\
\%\end{array}$ & $\begin{array}{c}\mathrm{Nb} \\
\mathrm{ppm}\end{array}$ & $\begin{array}{c}\mathrm{Ni} \\
\mathrm{ppm}\end{array}$ & $\begin{array}{c}\mathrm{P} \\
\mathrm{ppm}\end{array}$ & $\begin{array}{c}\mathrm{Pb} \\
\mathrm{ppm}\end{array}$ & $\begin{array}{c}\mathrm{Rb} \\
\mathrm{ppm}\end{array}$ & $\begin{array}{c}\mathrm{Re} \\
\mathrm{ppm}\end{array}$ & $\begin{array}{l}\mathrm{S} \\
\%\end{array}$ & $\begin{array}{c}\mathrm{Sb} \\
\mathrm{ppm}\end{array}$ & $\begin{array}{l}\mathrm{Sb} \\
\%\end{array}$ & $\begin{array}{c}\text { Se } \\
\text { ppm }\end{array}$ & $\begin{array}{c}\text { Sn } \\
\text { ppm }\end{array}$ & $\begin{array}{c}\text { Sn } \\
\text { ppm }\end{array}$ & $\begin{array}{c}\mathrm{Sr} \\
\mathrm{ppm}\end{array}$ & $\begin{array}{c}\text { Ta } \\
\mathrm{ppm}\end{array}$ & $\begin{array}{c}\text { Te } \\
\mathrm{ppm}\end{array}$ & $\begin{array}{c}\text { Th } \\
\text { ppm }\end{array}$ \\
\hline 05JEA49A & 13.6 & 0.11 & 429 & 0.62 & 0.03 & 2.8 & 1.9 & 200 & 1315 & 62.1 & $<0.002$ & 0.18 & 244 & --- & 2 & 29.3 & --- & 25.6 & 0.17 & $<0.05$ & 9.1 \\
\hline 05LF53B & 6.1 & 0.71 & 2020 & 1.18 & 0.3 & 3.2 & 12.7 & 920 & 424 & 41.7 & $<0.002$ & 0.02 & 57.3 & --- & 2 & 68.1 & --- & 80.7 & 0.22 & 0.08 & 11.3 \\
\hline 05LF61B & 9.3 & 0.17 & 103 & 2.55 & 0.08 & 16.3 & 1.6 & 990 & 5190 & 253 & $<0.002$ & 0.71 & 72.2 & --- & 2 & 34.4 & --- & 63.8 & 2.28 & $<0.05$ & 23.3 \\
\hline 05LF231A & 13.8 & 8.55 & 1855 & 4.77 & 0.25 & 10.4 & 47.4 & 230 & 10.1 & 6 & 0.022 & 1.92 & 10.9 & --- & 16 & 29.2 & --- & 215 & 0.66 & 0.48 & 6.9 \\
\hline 05MBW224A & 1.5 & 0.03 & 28 & 0.94 & 0.01 & 0.4 & 0.7 & 470 & 206 & 30 & $<0.002$ & 0.2 & 18.2 & --- & 2 & 0.7 & --- & 10.9 & $<0.05$ & $<0.05$ & 0.6 \\
\hline 05MBW298A & 22.9 & 0.45 & 197 & 0.43 & 0.13 & 5.5 & 2.4 & 810 & 26.5 & 217 & $<0.002$ & 0.73 & 50.3 & --- & 1 & 19.3 & --- & 19 & 0.43 & $<0.05$ & 11.8 \\
\hline 05MBW374A & 4.2 & 0.35 & 59 & 2.16 & 0.1 & 2.3 & 3.2 & 80 & 51.5 & 10.9 & $<0.002$ & 0.01 & 55.3 & --- & 1 & 6.7 & --- & 30.2 & 0.16 & 0.11 & 2.2 \\
\hline 05JEA121B & --- & --- & --- & --- & --- & --- & --- & --- & --- & --- & --- & --- & --- & --- & --- & --- & 114 & --- & --- & --- & --- \\
\hline 05LF141B & --- & --- & --- & --- & --- & --- & --- & --- & --- & --- & --- & --- & --- & 6.51 & --- & --- & 359 & --- & --- & --- & --- \\
\hline 05LF77A & --- & --- & --- & -- & --- & --- & --- & --- & --- & --- & --- & --- & --- & --- & --- & --- & 20 & -- & --- & --- & -- \\
\hline 05LF78A & --- & --- & --- & --- & --- & --- & --- & --- & --- & --- & --- & --- & --- & --- & --- & --- & $<5$ & -- & --- & --- & -- \\
\hline 05LF79B & --- & --- & --- & -- & --- & --- & --- & --- & --- & --- & --- & --- & --- & --- & --- & --- & 31 & --- & --- & --- & -- \\
\hline 05LF228A & --- & --- & --- & --- & --- & --- & --- & --- & --- & --- & --- & --- & --- & --- & --- & --- & 5 & --- & --- & --- & --- \\
\hline 05MBW50A & --- & --- & --- & -- & --- & -- & --- & --- & --- & --- & --- & --- & --- & --- & --- & --- & 17 & -- & --- & --- & -- \\
\hline 05MBW174A & --- & --- & --- & --- & --- & --- & --- & --- & --- & --- & --- & --- & --- & 6.3 & --- & --- & 155 & --- & --- & --- & - \\
\hline
\end{tabular}

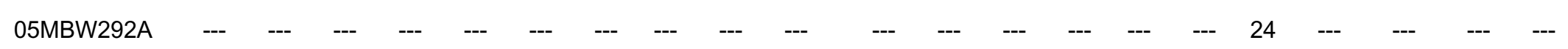

05MBW296B

05MBW303A

05MBW363A

05MBW407A

05Z108B 
Table A1. Location, description, and concentration of trace elements for samples collected in the Liberty Bell area of the Fairbanks A-4 Quadrangle, Alaska. Rock names in () are derived from geochemical data and rock textures in hand samples. Location coordinates were collected using a hand-held GPS unit (no differential correction was applied), and coordinates are presented in latitude and longitude (based on the NAD27 Alaska datum) and in UTM coordinates (based on the Clark 1866 spheroid, NAD27 datum, UTM zone 6 projection). Note: $-=$ not analyzed-continued.

\begin{tabular}{|c|c|c|c|c|c|c|c|c|}
\hline Sample & $\mathrm{Ti}$ & TI & $U$ & V & W & Y & $\mathrm{Zn}$ & $\mathrm{Zr}$ \\
\hline Number & $\%$ & ppm & ppm & ppm & ppm & ppm & ppm & $\mathrm{ppm}$ \\
\hline 05JEA49A & 0.054 & 0.93 & 2.6 & 8 & 3.7 & 3.8 & 19 & 8.6 \\
\hline 05LF53B & 0.066 & 0.51 & 21.3 & 54 & 2.3 & 19.4 & 92 & 13.7 \\
\hline 05LF61B & 0.134 & 3.81 & 10 & 9 & 9.7 & 14.8 & 83 & 94.7 \\
\hline 05LF231A & 0.275 & 0.18 & 9.5 & 114 & 1.4 & 33.5 & 351 & 73.5 \\
\hline 05MBW224A & $<0.005$ & 0.26 & 0.2 & 1 & 0.6 & 1.5 & 10 & 2.8 \\
\hline 05MBW298A & 0.094 & 1.89 & 1.1 & 14 & 4.8 & 11 & 18 & 21 \\
\hline 05MBW374A & 0.082 & 0.28 & 0.9 & 60 & 5.4 & 3.5 & 4 & 33.9 \\
\hline
\end{tabular}

$\begin{array}{lllllllll}\text { 05JEA121B } & --- & --- & --- & --- & --- & -- & --- & -- \\ \text { 05LF141B } & --- & --- & --- & --- & -- & -- & -- & -- \\ & & & & & & & & \\ & & & & & & & & \\ \text { 05LF77A } & --- & --- & --- & --- & --- & --- & --- & -- \\ \text { 05LF78A } & --- & --- & --- & --- & --- & --- & --- & ---\end{array}$

05LF79B

05LF228A

05MBW50A

05MBW174A

05MBW292A

05MBW296B

05MBW303A

\begin{tabular}{cccccccc}
--- & --- & --- & --- & --- & -- & -- & -- \\
\hline & & & & & & &
\end{tabular}

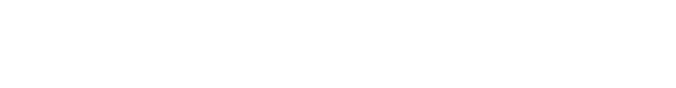

10

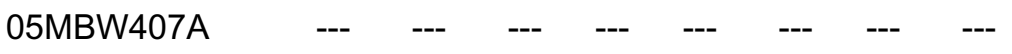

05Z108B 
Table A2. Detection limits for trace-element geochemical analyses. Analytical methods include: ICP-MS/AES = Inductively Coupled Plasma with Mass Spectroscopy or Atomic Emission Spectroscopy, ICP-AES = Inductively Coupled Plasma with Atomic Emission Spectroscopy, $P P-X R F=X$-Ray Fluorescence on pressed pellet, AAS = Atomic Absorption Spectroscopy. Four acid digestion = HF-HNO3-HClO4 and HCl leach. NOTE: * = possibly incomplete digestion dependent on mineralogy.

\begin{tabular}{|c|c|c|c|c|c|}
\hline Element & Units & $\begin{array}{l}\text { Lower } \\
\text { Detection } \\
\text { Limit }\end{array}$ & $\begin{array}{c}\text { Upper } \\
\text { Detection } \\
\text { Limit }\end{array}$ & Digestion & $\begin{array}{l}\text { Analytical } \\
\text { Method }\end{array}$ \\
\hline $\mathrm{Ag}$ & ppm & 0.01 & 100 & four acid & ICP-MS/AES \\
\hline $\mathrm{Ag}(+)$ & ppm & 1 & 1,000 & four acid & AAS \\
\hline $\mathrm{Al}$ & percent & 0.01 & 25 & four acid & ICP-MS/AES \\
\hline As & ppm & 0.2 & 10,000 & four acid & ICP-MS/AES \\
\hline $\mathrm{As}(+)$ & percent & 0.01 & 30 & four acid & AAS \\
\hline $\mathrm{Ba}^{*}$ & ppm & 10 & 10,000 & four acid & ICP-MS/AES \\
\hline $\mathrm{Be}$ & ppm & 0.05 & 1,000 & four acid & ICP-MS/AES \\
\hline $\mathrm{Bi}$ & ppm & 0.01 & 10,000 & four acid & ICP-MS/AES \\
\hline $\mathrm{Ca}$ & percent & 0.01 & 25 & four acid & ICP-MSIAES \\
\hline $\mathrm{Cd}$ & ppm & 0.02 & 500 & four acid & ICP-MS/AES \\
\hline $\mathrm{Ce}$ & ppm & 0.01 & 500 & four acid & ICP-MS/AES \\
\hline Co & ppm & 0.1 & 10,000 & four acid & ICP-MS/AES \\
\hline $\mathrm{Cr}^{\star}$ & ppm & 1 & 10,000 & four acid & ICP-MS/AES \\
\hline $\mathrm{Cs}$ & ppm & 0.05 & 500 & four acid & ICP-MS/AES \\
\hline $\mathrm{Cu}$ & ppm & 0.2 & 10,000 & four acid & ICP-MS/AES \\
\hline $\mathrm{Fe}$ & percent & 0.01 & 25 & four acid & ICP-MS/AES \\
\hline $\mathrm{Ga}$ & ppm & 0.05 & 500 & four acid & ICP-MSIAES \\
\hline $\mathrm{Ge}$ & ppm & 0.05 & 500 & four acid & ICP-MS/AES \\
\hline $\mathrm{Hf}$ & ppm & 0.1 & 500 & four acid & ICP-MS/AES \\
\hline In & ppm & 0.005 & 500 & four acid & ICP-MS/AES \\
\hline K & percent & 0.01 & 10 & four acid & ICP-MS/AES \\
\hline $\mathrm{La}$ & ppm & 0.5 & 500 & four acid & ICP-MSIAES \\
\hline $\mathrm{Li}$ & ppm & 0.2 & 500 & four acid & ICP-MS/AES \\
\hline $\mathrm{Mg}$ & percent & 0.01 & 15 & four acid & ICP-MS/AES \\
\hline $\mathrm{Mn}$ & ppm & 5 & 10,000 & four acid & ICP-MSIAES \\
\hline Mo & ppm & 0.05 & 10,000 & four acid & ICP-MS/AES \\
\hline $\mathrm{Na}$ & percent & 0.01 & 10 & four acid & ICP-MS/AES \\
\hline $\mathrm{Nb}$ & ppm & 0.1 & 500 & four acid & ICP-MS/AES \\
\hline $\mathrm{Ni}$ & ppm & 0.2 & 10,000 & four acid & ICP-MS/AES \\
\hline $\mathrm{P}$ & ppm & 10 & 10,000 & four acid & ICP-MS/AES \\
\hline $\mathrm{Pb}$ & ppm & 0.5 & 10,000 & four acid & ICP-MS/AES \\
\hline $\mathrm{Rb}$ & ppm & 0.1 & 500 & four acid & ICP-MS/AES \\
\hline $\mathrm{Re}$ & ppm & 0.002 & 50 & four acid & ICP-MS/AES \\
\hline S & percent & 0.01 & 10 & four acid & ICP-MS/AES \\
\hline $\mathrm{Sb}$ & ppm & 0.05 & 1,000 & four acid & ICP-MS/AES \\
\hline $\mathrm{Sb}(+)$ & percent & 0.01 & 100 & $\mathrm{KClO}_{3} / \mathrm{HCl}$ & ICP-AES or AAS \\
\hline $\mathrm{Se}$ & ppm & 1 & 1,000 & four acid & ICP-MSIAES \\
\hline $\mathrm{Sn}^{*}$ & ppm & 0.2 & 500 & four acid & ICP-MSIAES \\
\hline $\operatorname{Sn}(+)$ & ppm & 5 & 10,000 & - & PP-XRF \\
\hline $\mathrm{Sr}$ & ppm & 0.2 & 10,000 & four acid & ICP-MS/AES \\
\hline $\mathrm{Ta}^{\star}$ & ppm & 0.05 & 100 & four acid & ICP-MSIAES \\
\hline $\mathrm{Te}$ & ppm & 0.05 & 500 & four acid & ICP-MS/AES \\
\hline Th & ppm & 0.2 & 500 & four acid & ICP-MS/AES \\
\hline $\mathrm{Ti}^{\star}$ & percent & 0.005 & 10 & four acid & ICP-MS/AES \\
\hline $\mathrm{Tl}$ & ppm & 0.02 & 500 & four acid & ICP-MS/AES \\
\hline$U$ & ppm & 0.1 & 500 & four acid & ICP-MS/AES \\
\hline V & ppm & 1 & 10,000 & four acid & ICP-MSIAES \\
\hline$W^{*}$ & ppm & 0.1 & 10,000 & four acid & ICP-MS/AES \\
\hline $\mathrm{Y}$ & ppm & 0.1 & 500 & four acid & ICP-MSIAES \\
\hline $\mathrm{Zn}$ & ppm & 2 & 10,000 & four acid & ICP-MSIAES \\
\hline$Z r^{*}$ & ppm & 0.5 & 500 & four acid & ICP-MS/AES \\
\hline
\end{tabular}


This page intentionally left blank. 
Table A3. Location, description, and concentration of major oxides, minor oxides, and trace elements for samples collected in the Liberty Bell area of the Fairbanks A-4 Quadrangle, Alaska. Rootnames are derived from geochemical data and rock textures in hand samples. Location coordinates were collected using a hand-held
zone 6 projection). Note: $-=$ not analyzed.

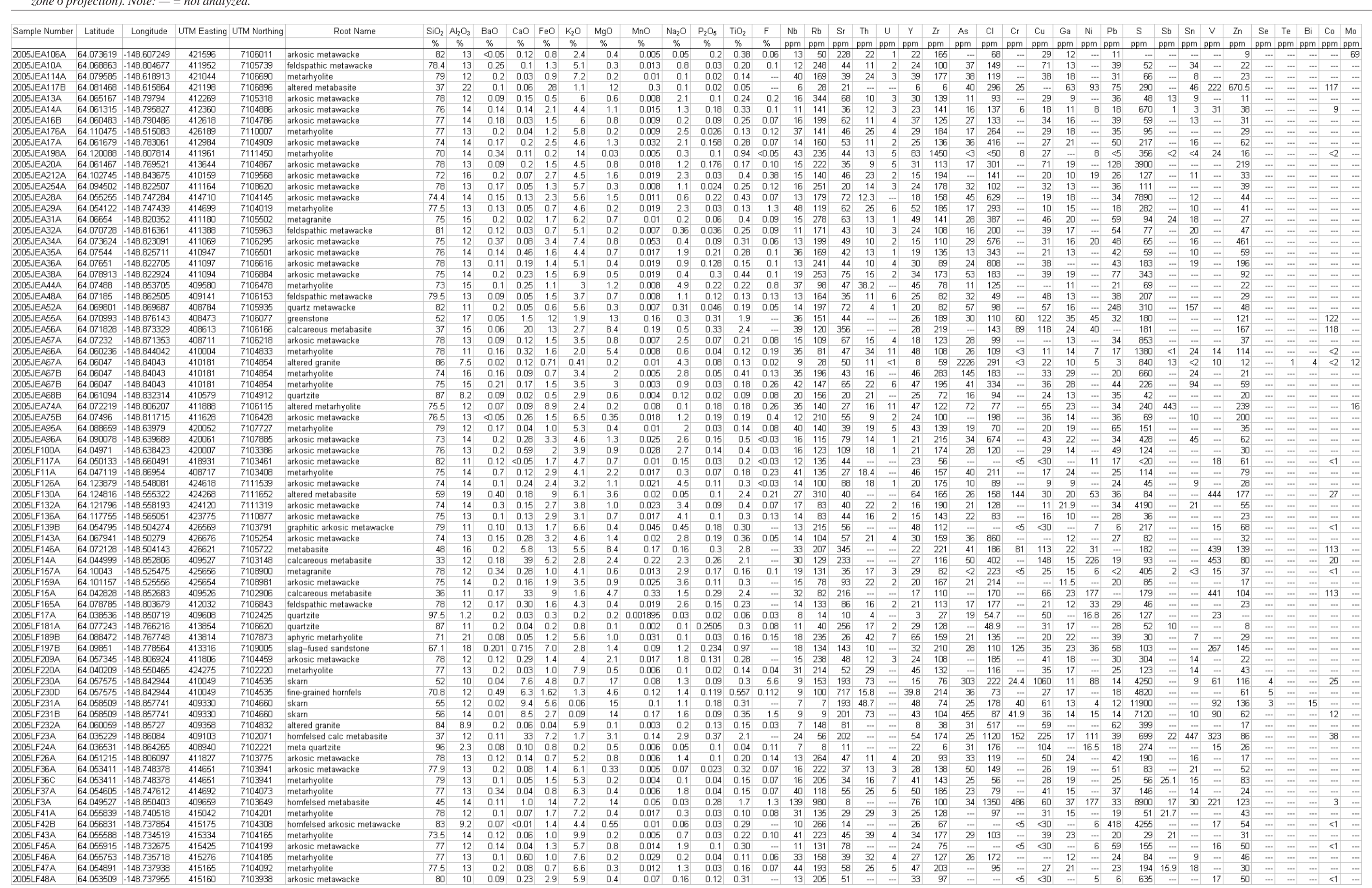


Table A3. Location, description, and concentration of major oxides, minor oxides, and trace elements for samples collected in the Liberty Bell area of the Fairbanks A-4 Quadrangle, Alaska. Root names are derived from geochemical data and rock textures in hand samples. Location (bif zone 6 projection). Note: - = not analyzed-continued.

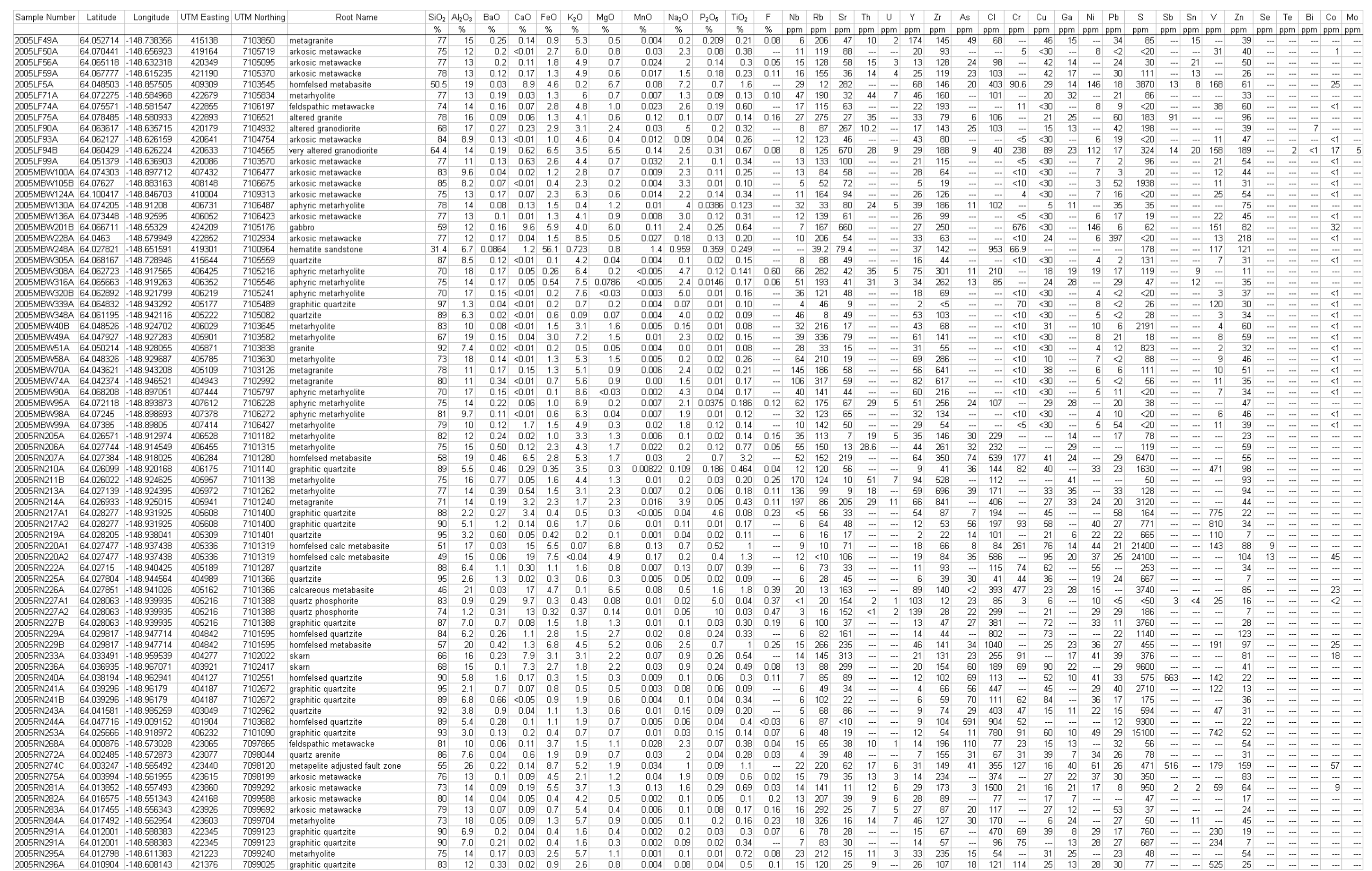


Table A3. Location, description, and concentration of major oxides, minor oxides, and trace elements for samples collected in the Liberty Bell area of the Fairbanks A-4 Quadrangle, Alaska. Root names are derived from geochemical data and rock textures in hand samples. Location coordinates were collected using a hand-held GPS unit (no differential correction was applied), and coordinates are presented in latitude and longitude (based on the NAD27 Alaska datum) and in UTM coordinates (based on the Clark 1866 spheroid, NAD27 datum, UTM zone 6 projection). Note: $-=$ not analyzed-continued.

\begin{tabular}{|c|c|c|c|c|c|c|c|c|c|c|c|c|c|c|c|c|c|c|c|c|c|c|c|c|c|c|c|c|c|c|c|c|c|}
\hline ple Number & Latitude & gitude & Eas & UTM Nothing & Root Name & $\mathrm{A}_{2} \mathrm{O}$ & $\frac{20}{6}$ & & & 60 & $\begin{array}{l}\text { MgO } \\
\% \\
\end{array}$ & $\begin{array}{l}\text { MnO } \\
\% \\
0043\end{array}$ & $\begin{array}{l}\mathrm{N}_{22} \mathrm{O} \\
\% \\
\%\end{array}$ & $\begin{array}{l}P_{2} \mathrm{O}_{5} \\
\% \\
\\
\end{array}$ & $\mathrm{TiO}_{2}$ & F 1 & $\frac{194}{9}$ & si & h & $\mathrm{Zr}$ & As & is & $\mathrm{Cr}$ & $\mathrm{Cu} \quad \mathrm{G}_{2} \mathrm{C}$ & $\mathrm{Ni}$ & $\begin{array}{l}\mathrm{Pb} \\
\mathrm{ppm}\end{array}$ & 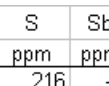 & $\begin{array}{ll}S b & S n \\
S\end{array}$ & in & $\begin{array}{ll}\mathrm{Zn} \\
\mathrm{pm}\end{array}$ & $x_{0}-2$ & & $\begin{array}{l}c o k \\
n \text { ppom pp }\end{array}$ \\
\hline 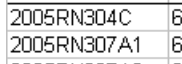 & $\begin{array}{l}644103011 \\
64.015347\end{array}$ & 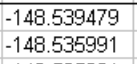 & $\begin{array}{l}4247311 \\
424915\end{array}$ & 8876 & thyolite & 38 & & $\frac{1.09}{1.44}$ & $\begin{array}{l}1.5 . \\
20\end{array}$ & 4 & $\begin{array}{l}1.2 \\
5.8\end{array}$ & $\begin{array}{l}0.043 \\
0.23\end{array}$ & $\begin{array}{ll}2.1 \\
0.2 \\
0.2\end{array}$ & $\begin{array}{l}0.2 \\
0.24\end{array}$ & $\frac{62}{2}$ & & & & & & & & & & & & & & & & & & \\
\hline 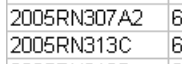 & $\begin{array}{l}64.105374 \\
66.02394\end{array}$ & 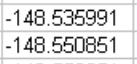 & $\begin{array}{l}{ }_{424915} \\
424212\end{array}$ & $\begin{array}{l}7099433 \\
71000408\end{array}$ & $\begin{array}{l}\text { calcarefous metatabaste } \\
\text { graphitic quartzite }\end{array}$ & & & $\begin{array}{ll}0.3 & 0 \\
0.04 & 0\end{array}$ & $\begin{array}{ll}113 & 13 \\
0.04 & 0.3\end{array}$ & $\begin{array}{l}3.7 \\
0.5\end{array}$ & $\begin{array}{l}5.5 \\
0.3\end{array}$ & $\begin{array}{l}0.18 \\
0.004\end{array}$ & $\begin{array}{l}0.16 \\
0.04 \\
0.04\end{array}$ & $\begin{array}{ll}0.149 & 0 \\
0.06 & 0\end{array}$ & $\begin{array}{l}1.8 \\
0.04\end{array}$ & 0.06 & $\begin{array}{cc}12 & 134 \\
6 & 25\end{array}$ & $\begin{array}{l}283 \\
<10\end{array}$ & & $\begin{array}{l}12 \\
14 \\
\end{array}$ & $\begin{array}{l}94 \\
14 \\
1422 \\
22\end{array}$ & $\begin{array}{ll}116 & 181 \\
22 & 126\end{array}$ & $\begin{array}{l}1 \\
6 \\
6\end{array}$ & $1{ }^{112}$ & a & $\begin{array}{c}16 \\
268\end{array}$ & $\begin{array}{l}91 \\
42\end{array}$ & & 45 & 138 & & & \\
\hline 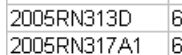 & $\begin{array}{l}64.02934 ; \\
604010337\end{array}$ & 148.550551 & $\begin{array}{l}424212 \\
426783 \\
4\end{array}$ & $\begin{array}{l}7100408 \\
709830\end{array}$ & $\begin{array}{l}\text { metapelite } \\
\text { metataelite }\end{array}$ & & & & & $\begin{array}{l}5.4 \\
55\end{array}$ & $\begin{array}{l}1.6 \\
0.5\end{array}$ & 0.032 & $\begin{array}{l}0.05 \\
0.40\end{array}$ & $\begin{array}{ll}0.04 & 0 \\
0.029 & 0\end{array}$ & $\begin{array}{l}0.12 \\
0.14\end{array}$ & $\begin{array}{l}0.20 \\
0.22\end{array}$ & $\begin{array}{ll}17 & 220 \\
17 & 346\end{array}$ & $\begin{array}{r}6 \\
31 \\
31\end{array}$ & & $\begin{array}{l}32 \\
39.8 \\
-12\end{array}$ & $\begin{array}{ll}117 & 35 \\
95 & 40\end{array}$ & $\begin{array}{ll}35 & 280 \\
40 & 280 \\
453\end{array}$ & & 32 & 19 & 89 & $\begin{array}{l}343 \\
422\end{array}$ & & & $\begin{array}{l}47 \\
48\end{array}$ & & & \\
\hline & 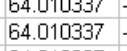 & & & & pemle & & & 0.10 & & & 0.4 & & 50.20 & & & & & & & & & 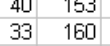 & & 25 & 35 & & 3642 & & & $\begin{array}{l}48 \\
39\end{array}$ & & & \\
\hline & & & & & quartrz metawacke & & & .070 & & 4.4 & 0.4 & & & & & & & 26 & & 25 & $107 \quad 21$ & $\begin{array}{ll}21 & 71\end{array}$ & & 15 & 12 & 1 & 48 & & & 29 & & & \\
\hline & & & & & awacke & & & $1.07<$ & & 0.6 & $\begin{array}{l}0.8 \\
7.1\end{array}$ & & 30.06 & & & & & & & 34 3 & & 30 & 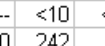 & 30 & & 9 & & & & & & & \\
\hline & & & & & & & & & & 2.8 & & & & & & & & 70 & & $<10$ & & & 0 & & & & 29 & & & 187 & & & 1 \\
\hline & & & & & & & & $\begin{array}{l}.050 \\
.02 \\
20\end{array}$ & & & & & & & & - & & & & 10 & & & & ( & & 9 & 260 & & & & & & \\
\hline $327 \mathrm{~B}$ & $\begin{array}{l}644.1933282 \\
64.013341\end{array}$ & 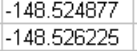 & $\begin{array}{l}4255453 \\
425387\end{array}$ & $\begin{array}{l}7099201 \\
7099198\end{array}$ & $\begin{array}{l}\text { filldspatici } m \\
\text { grenstone }\end{array}$ & & & & 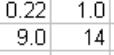 & $\begin{array}{l}3.3 \\
1.2 \\
1.2\end{array}$ & $\begin{array}{l}1.3 \\
6.2 \\
6.2 \\
\end{array}$ & $16 \mathrm{~T}$ & 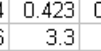 & & & 1.15 & $\begin{array}{ll}188 & 98 \\
28 & 62\end{array}$ & $\begin{array}{l}11 \\
166 \\
\end{array}$ & 8 & 46 & $\begin{array}{ll}94 & 28 \\
234 & 25 \\
55\end{array}$ & $\begin{array}{ll}28 & 145 \\
55 & 148\end{array}$ & $\begin{array}{lll}5 & \cdots \\
8 & 448 & \\
\end{array}$ & $\begin{array}{l}35 \\
17 \\
7\end{array}$ & 2 & 28 & 91 & & & $\begin{array}{l}34 \\
34\end{array}$ & & & \\
\hline & & & & & greenstone & & & & & & 10 & & & & & & & 216 & & 25 & & & 8 & 23 & & & $\begin{array}{l}18 \\
87\end{array}$ & & & & & & \\
\hline & & & & & 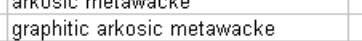 & & & & & ${ }_{3}^{4}$ & 0.5 & & .7 & & & & & 14 & & & 19 & 24 & & 16 & & 1 & 348 & & & & & & \\
\hline & & & & & arkosic metaw- & & & & & & 0.6 & & 0.07 & & & 14 & & (4) & & & & & & 16 & & 3 & 560 & & & & & & \\
\hline & & & & & strathici & & & $\begin{array}{l}0.20 \\
0.70 \\
0\end{array}$ & & $\begin{array}{l}5.9 \\
56\end{array}$ & 4 & $4^{4}$ & 0 & & & 108 & (16) & 66 & & & & 104 & & 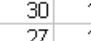 & & 6 & 580 & & & 15 & & & \\
\hline & 64.020189. & -148.5355828 & 424448 & 7099972 & altered diabase & & & 0.3 & 4.29 .5 & 4.2 & 1.5 & 0.57 & 0.3 & 0.36 & & 0.11 & 11183 & $\begin{array}{rr}185 & 16 \\
185\end{array}$ & 16 & 66 & $\begin{array}{ll}261 & 52 \\
262 & 52\end{array}$ & $52 \quad 395$ & $\begin{array}{ll}5 & 239 \\
\end{array}$ & 41 & & 1 & 220 & & & 385 & & & 40 \\
\hline & 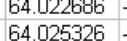 & 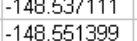 & 年44860 & 71700252 & arkosic metawacke & & & $.51<1$ & & & 2 & tit & 1.1 & D. 01 & 7 & & & 7 & & 望 & 79 & 95 & 5 & 染1 & & 318 & sis & & & 41 & & & \\
\hline A4tB & $\begin{array}{l}64.049239 \\
6.03\end{array}$ & 146.852517 & 409550 & 7103520 & $\begin{array}{l}\text { homfiledsed metabasite } \\
\text { heme }\end{array}$ & & & . & 2.612 & 5.8 & 10 & 0.07 & 0.5 & 0.33 & 2.2 & & 16 & 91 & & 25 & & 126 & 5.342 & & 14 & -4 & 0200 & & 46 & 70 & & & \\
\hline & 64.124237: & 148.8883 & & 71126 & metagranite & & & & $\begin{array}{l}0.24 \\
064 \\
0.34\end{array}$ & & 0.6 & & 12 & 0.16 & & . & 21 & & & & & 35 & & & & & 68 & & & 58 & & & \\
\hline & & & & & 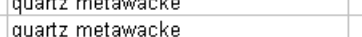 & & & & & & & & 12 & & & & & 26.7 & & & & & & & & & 64 & & & & & & \\
\hline & & & & & quatz arenite & 96 & & & & 0.6 & 0.09 & 87 & 0.05 & & & & & & & & & 46 & & & & & 5 & & & & & & \\
\hline & & & & & 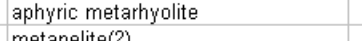 & & & 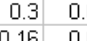 & 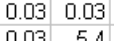 & & 2 & & 5 & & & 134 & 7 & & & & & & & & & 9 & 90 & & & 36. & & & \\
\hline & & & & & 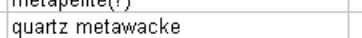 & & & 06 & & & & & & & & & & & & & & & & & & & 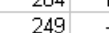 & & & & & & \\
\hline & 64.077. & & & & arkosic metawacke & & & & & & & & 0.9 & & & & & & & & & & & & & & & & & & & & \\
\hline & & . & & & 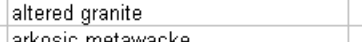 & & & 38 & 12 & & & & 1.2 & & & & 14 & & & & & 54 & & & & & & & & & & & \\
\hline & & & & 71066765 & alkustl melawache & & & 0.16 & 0.19 & & 0.7 & & 1.2 & 0.19 & 35 & 0.12 & 16 & 6 & 12 & 38 & 10 & 81 & & 26 & & 24 & 92 & & & 35 & 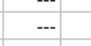 & & \\
\hline $\begin{array}{l}0 A \\
A A \\
A\end{array}$ & $\begin{array}{l}64.0788789 \\
654771997\end{array}$ & 148.970912 & 4036 & 7107095 & $\begin{array}{l}\text { arkosic metawackek } \\
\text { ararkosic metawake }\end{array}$ & 75 & & $0.17<6<-3$ & $<0.1$ & & 0.6 & 0.024 & 0.17 & 0.03 & 48 & & $\begin{array}{lll}14 & 222 \\
10 & 117 & \end{array}$ & 58 & & 33 & & & 6 & 30 & & 17 & 222 & & & 6 & & & \\
\hline & & & & & alik & & & & 10 & & 10 & & 19 & & & 0.0 & & & & & & & & & & & 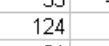 & & & & & & \\
\hline & $\begin{array}{l}64.0 \\
64.0 \\
-10\end{array}$ & 148.87782424 & $\begin{array}{l}413 \\
413 \\
4\end{array}$ & $\begin{array}{l}710 \\
710\end{array}$ & 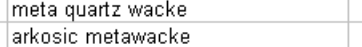 & 86 & & 0.03 & 8 & 1.4 & 0.16 & 0.0 .007 & $\begin{array}{l}0.1 \\
0.13\end{array}$ & 0.04 & & & $\begin{array}{l}14 \\
10\end{array}$ & 41 & 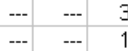 & $\begin{array}{l}34 \\
17\end{array}$ & 80 & & 10 & 30 & & 3 & 384 & & & 37 & & & \\
\hline & & & & & ke & & & 015 & & 3.9 & & & 3.3 & & & & & & & & & & ${ }_{55}^{25}$ & & & & & & & & & & \\
\hline $2 A$ & 64.09 & 1775 & & $\begin{array}{l}7100 \\
7708 \\
7\end{array}$ & metawacke & 74 & & $\begin{array}{ll}0.19 & 0 \\
0.19 & 0\end{array}$ & 0.06 & 6.4 & 0.9 & 0.039 & 2 & 0.06 & 39 & 0.07 & 16 & & 8 & 24 & 155 & 01 & & 20 & & 29 & 33 & & & - & & & \\
\hline & $\begin{array}{l}64.08 \\
64.08\end{array}$ & $\begin{array}{l}48.78272636 \\
48.729143\end{array}$ & & $\begin{array}{l}7107 \\
7107\end{array}$ & arkosicic $n$ & & & & 0.23 & .5 & 1.4 & $\begin{array}{l}0.02 \\
0.01\end{array}$ & 2.8 & 0.04 & 1.4 & 1.13 & 17 & & $\frac{8}{2}$ & 22 & 190 & $\begin{array}{l}18 \\
14 \\
14\end{array}$ & & 21 & 0 & $\begin{array}{l}466 \\
146 \\
\end{array}$ & 58 & & & 27 & & & \\
\hline & & & & & & & & & & 5.5 & & & & & & & & & & & & & & & & & & & & & & & \\
\hline & & & & & & & & 0.17 & 09 & 5.5 & & 0.05 & 0.04 & 0.04 & & & 18 & & & & & 3 & & & & & & & & & & & \\
\hline $656 \mathrm{~A}$ & $\begin{array}{l}64.4928253 \\
64.000421\end{array}$ & 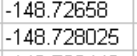 & $\begin{array}{l}4153744 \\
445726 \\
4\end{array}$ & $\begin{array}{ll}710 \\
710\end{array}$ & $\begin{array}{l}\text { attreded gree } \\
\text { arkosic met }\end{array}$ & 76 & & $\begin{array}{l}0.05 \\
0.05 \\
\end{array}$ & $\begin{array}{l}0.9 \\
0.17 \\
0.1 .73\end{array}$ & 5.6. & $\begin{array}{l}3.6 \\
0.6\end{array}$ & $\begin{array}{l}0.3 \\
0.02\end{array}$ & $\begin{array}{l}0.08 \\
1.8 \\
1.8\end{array}$ & 0.48 & 82 & & $\begin{array}{lll}8 & 706 & 106 \\
5\end{array}$ & 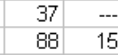 & & $\begin{array}{l}35 \\
21\end{array}$ & $\begin{array}{l}245 \\
457\end{array}$ & $\begin{array}{l}67 \\
\begin{array}{c}67 \\
28\end{array} 2150 \\
216\end{array}$ & $\frac{5}{5}$ & $\begin{array}{l}85 \\
24\end{array}$ & 15 & 4 & $\begin{array}{l}51 \\
17 \\
17\end{array}$ & & & 5 & & & \\
\hline ZZBGA & $\begin{array}{l}64.4775585 \\
64.076552\end{array}$ & $\begin{array}{l}148.8724842 \\
44.731769\end{array}$ & $\begin{array}{l}4157 \\
4155\end{array}$ & $\begin{array}{l}71066 \\
77065\end{array}$ & & 91 & & 0.02 & $\begin{array}{l}0.10 \\
0.05\end{array}$ & 18 & $\begin{array}{l}0.4 \\
0.3\end{array}$ & 0.001 & $\begin{array}{l}0.2 \\
0.06\end{array}$ & 0.06 & 20 & & 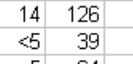 & 61 & $\begin{array}{l}4 \\
1\end{array}$ & $22+2$ & 27 & $\begin{array}{l}92 \\
102\end{array}$ & & & & $\begin{array}{l}39 \\
22 \\
22\end{array}$ & 66 & & & 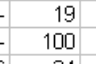 & & & \\
\hline م055258B & $\begin{array}{l}64.076652 \\
65476262\end{array}$ & $\begin{array}{l}-148.731769 \\
-148.681014\end{array}$ & 418006 & 71060998 & $\begin{array}{l}\text { silicified metarhyolite } \\
\text { eliced }\end{array}$ & & & & & \begin{tabular}{|l|}
2.3 \\
3.0
\end{tabular} & $\begin{array}{l}0.14 \\
0.09\end{array}$ & $\begin{array}{l}0.005 \\
0.012\end{array}$ & 0.11 & $\begin{array}{ll}0.02 & 0 \\
0.02 & 0\end{array}$ & $\begin{array}{l}0.09 \\
0.10\end{array}$ & 0.0 & $\begin{array}{rr}5 & 64 \\
25 & 87\end{array}$ & 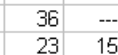 & $\begin{array}{ll}15 & 2 \quad 6\end{array}$ & & $109<2<-2$ & $<<<50$ & $\mid<10$ & $\begin{array}{c}<30 \\
<20\end{array}$ & $\cdots 5$ & $\begin{array}{l}30 \\
12\end{array}$ & $\begin{array}{l}128 \\
36\end{array}$ & & & $\begin{array}{r}34 \\
27\end{array}$ & & & $<3 \ldots$ \\
\hline
\end{tabular}


This page intentionally left blank. 


\section{Appendix B}

\section{${ }^{40} \mathrm{Ar} /{ }^{39} \mathrm{Ar}$ analyses}

For ${ }^{40} \mathrm{Ar} /{ }^{39} \mathrm{Ar}$ analysis, six samples were submitted to the Geochronology Laboratory at UAF. The samples were crushed, washed, and sieved to either 100-250 or 250-500 micron size fractions, and hand picked for datable mineral phases (one per sample). The monitor mineral MMhb-1(Samson and Alexander, 1987) with an age of 513.9 Ma (Lanphere and Dalrymple, 2000) was used to monitor neutron flux (and calculate the irradiation parameter, J). The samples and standards were wrapped in aluminum foil and loaded into aluminum cans of $2.5 \mathrm{~cm}$ diameter and $6 \mathrm{~cm}$ height. The samples were irradiated in position $5 \mathrm{c}$ of the uranium-enriched research reactor of McMaster University in Hamilton, Ontario, Canada, for 20 megawatt-hours.

Upon their return from the reactor, the samples and monitors were loaded into 2-mm-diameter holes in a copper tray that was then loaded in an ultra-high vacuum extraction line. The monitors were fused, and samples heated, using a 6-watt argon-ion laser following the technique described in York and others (1981), Layer and others (1987), and Layer (2000). Argon purification was achieved using a liquid nitrogen cold trap and an SAES Zr-Al getter at $400^{\circ} \mathrm{C}$. The samples were analyzed in a VG3600 mass spectrometer at the Geophysical Institute, University of Alaska Fairbanks. The argon isotopes measured were corrected for system blank and mass discrimination, as well as calcium, potassium, and chlorine interference reactions following procedures outlined in McDougall and Harrison (1999). System blanks generally were $2 \times 10^{-16} \mathrm{~mol}^{40} \mathrm{Ar}$ and $2 \times 10^{-18} \mathrm{~mol}{ }^{36} \mathrm{Ar}$, which are 10 to 50 times smaller than fraction volumes. Mass discrimination was monitored by running both calibrated air shots and a zero-age glass sample. These measurements were made on a weekly to monthly basis to check for changes in mass discrimination.

Sample information and a summary of all the ${ }^{40} \mathrm{Ar} /{ }^{39} \mathrm{Ar}$ results are given in table 5 , with all ages quoted to the \pm 1 sigma level and calculated using the constants of Steiger and Jaeger (1977). (Sample 2005LF197B [table 5] does not have associated data in this appendix. The sample was too young to be dated by this method.) The integrated age is the age given by the total gas measured and is equivalent to a potassium-argon (K-Ar) age. The spectrum provides a plateau age if three or more consecutive gas fractions represent at least 50 percent of the total gas release and are within two standard deviations of each other (Mean Square Weighted Deviation less than 2.5). If a sample has experienced a partial thermal reset and (or) has cooled very slowly, argon is lost from the margins of the sample mineral. This argon loss is reflected in lower apparent-ages for the lower-temperature fraction. In this case, the lowest temperature fraction shows the approximate age of reheating (reset age). The age, $\mathrm{Ca} / \mathrm{K}$, and $\mathrm{Cl} / \mathrm{K}$ spectra plots and detailed analyses are given in tables B1-B7. 
This page has intentionally been left blank. 
Table B1. ${ }^{40} \mathrm{Ar} /{ }^{39} \mathrm{Ar}$ spectra and step-heating data for sample 2005JDDS01. Plateau age of 1.026 $\pm 0.057 \mathrm{Ma}$.
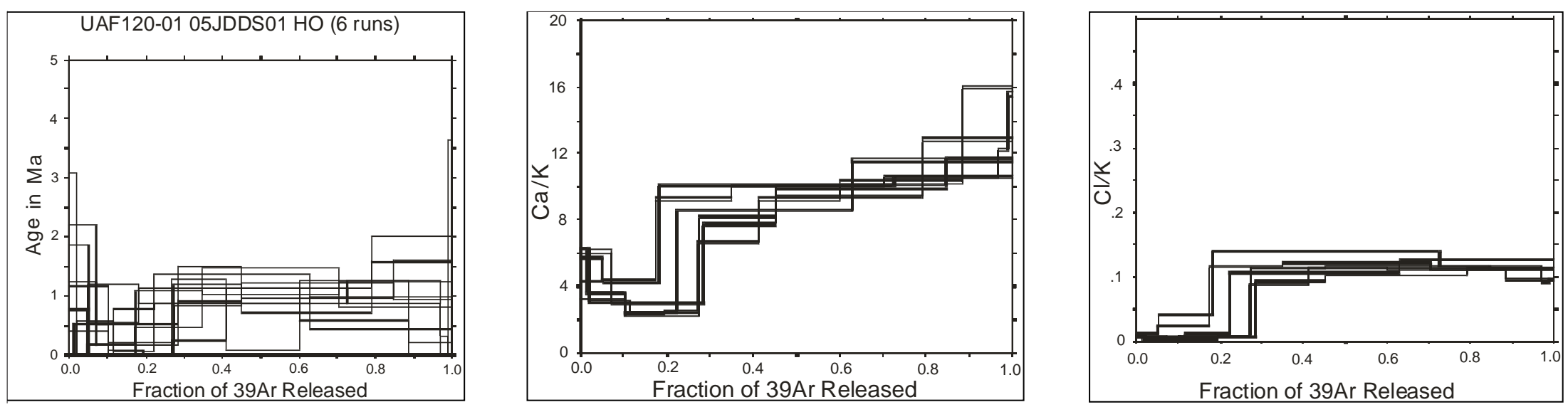

\begin{tabular}{|c|c|c|c|c|c|c|c|c|c|c|c|c|c|c|c|c|}
\hline \multicolumn{8}{|c|}{ UAF120-01 05JDDS01 HO\#2 } & \multicolumn{9}{|c|}{ Weighted average of $\mathrm{J}$ from standards $=0.002351+/-0.000011$} \\
\hline $\begin{array}{l}\text { Laser } \\
(\mathrm{mW}) \\
\end{array}$ & $\begin{array}{l}\text { Cum. } \\
{ }^{39} \mathrm{Ar}\end{array}$ & $\begin{array}{l}{ }^{40} \mathrm{Ar} /{ }^{39} \mathrm{Ar} \\
\text { measured }\end{array}$ & \pm & $\begin{array}{l}{ }^{37} \mathrm{Ar}{ }^{39} \mathrm{Ar} \\
\text { measured }\end{array}$ & \pm & $\begin{array}{l}{ }^{36} \mathrm{Ar} r^{39} \mathrm{Ar} \\
\text { measured }\end{array}$ & \pm & $\begin{array}{l}\% \text { Atm. } \\
{ }^{40} \mathrm{Ar}\end{array}$ & $\mathrm{Ca} / \mathrm{K}$ & \pm & $\mathrm{Cl} / \mathrm{K}$ & & ${ }^{40} \mathrm{Ar} \mathrm{r}^{*} \mathrm{H}^{39} \mathrm{Ar}$ & \pm & $\begin{array}{l}\text { Age } \\
(\mathrm{Ma}) \\
\end{array}$ & $\begin{array}{c} \pm \\
(\mathrm{Ma}) \\
\end{array}$ \\
\hline 500 & 0.0134 & 12.949 & 0.151 & 3.3954 & 0.0407 & 0.0545 & 0.0097 & 122.7 & 6.2439 & 0.0750 & 0.00744 & 0.00081 & -2.9396 & 2.8721 & -12.51 & 12.26 \\
\hline 1000 & 0.1009 & 1.357 & 0.023 & 1.9643 & 0.0125 & 0.0052 & 0.0006 & 104.0 & 3.6088 & 0.0230 & 0.00350 & 0.00013 & -0.0528 & 0.1773 & -0.22 & 0.75 \\
\hline 2000 & 0.2698 & 1.038 & 0.009 & 1.3410 & 0.0088 & 0.0044 & 0.0006 & 119.1 & 2.4627 & 0.0161 & 0.00816 & 0.00020 & -0.1929 & 0.1713 & -0.82 & 0.73 \\
\hline 3000 & 0.4105 & 2.652 & 0.016 & 3.6045 & 0.0246 & 0.0092 & 0.0004 & 93.2 & 6.6293 & 0.0453 & 0.08805 & 0.00062 & 0.1797 & 0.1226 & 0.76 & 0.52 \\
\hline 4000 & 0.5990 & 4.027 & 0.070 & 5.0282 & 0.0358 & 0.0143 & 0.0004 & 96.4 & 9.2564 & 0.0662 & 0.11384 & 0.00089 & 0.1445 & 0.1218 & 0.61 & 0.52 \\
\hline 6000 & 0.8841 & 5.805 & 0.039 & 5.5798 & 0.0406 & 0.0202 & 0.0003 & 96.2 & 10.2754 & 0.0750 & 0.11166 & 0.00074 & 0.2190 & 0.0804 & 0.93 & 0.34 \\
\hline 9000 & 1.0000 & 14.159 & 0.097 & 8.6744 & 0.0635 & 0.0504 & 0.0006 & 100.8 & 16.0068 & 0.1178 & 0.09527 & 0.00083 & -0.1197 & 0.1708 & -0.51 & 0.72 \\
\hline \multicolumn{8}{|c|}{ UAF120-01 05JDDS01 HO\#3 } & \multicolumn{9}{|c|}{ Weighted average of $\mathrm{J}$ from standards $=0.002351+1-0.000011$} \\
\hline $\begin{array}{l}\text { Laser } \\
(\mathrm{mW})\end{array}$ & $\begin{array}{l}\text { Cum. } \\
{ }^{3 y} \mathrm{Ar}\end{array}$ & $\begin{array}{l}{ }^{40} \mathrm{Ar} r^{39} \mathrm{Ar} \\
\text { measured }\end{array}$ & \pm & $\begin{array}{l}{ }^{37} \mathrm{Ar}{ }^{39} \mathrm{Ar} \\
\text { measured }\end{array}$ & \pm & $\begin{array}{l}{ }^{36} \mathrm{Ar} r^{39} \mathrm{Ar} \\
\text { measured }\end{array}$ & \pm & $\begin{array}{l}\% \text { Atm. } \\
{ }^{40} \mathrm{Ar}\end{array}$ & $\mathrm{Ca} / \mathrm{K}$ & \pm & $\mathrm{Cl} / \mathrm{K}$ & \pm & ${ }^{40} \mathrm{Ar} * \beta^{39} \mathrm{Ar}_{\mathrm{K}}$ & \pm & $\begin{array}{l}\text { Age } \\
(\mathrm{Ma}) \\
\end{array}$ & $\begin{array}{c} \pm \\
(\mathrm{Ma}) \\
\end{array}$ \\
\hline 1000 & 0.0519 & 6.194 & 0.036 & 2.3346 & 0.0139 & 0.0204 & 0.0004 & 95.0 & 4.2902 & 0.0256 & 0.01189 & 0.00016 & 0.3065 & 0.1305 & 1.30 & 0.55 \\
\hline 2000 & 0.1803 & 2.100 & 0.013 & 2.2719 & 0.0158 & 0.0069 & 0.0003 & 90.2 & 4.1749 & 0.0290 & 0.04117 & 0.00032 & 0.2037 & 0.0763 & 0.86 & 0.32 \\
\hline 3000 & 0.7254 & 3.898 & 0.025 & 5.4861 & 0.0369 & 0.0137 & 0.0001 & 93.8 & 10.1022 & 0.0682 & 0.14016 & 0.00095 & 0.2393 & 0.0312 & 1.01 & 0.13 \\
\hline 4000 & 0.9694 & 4.530 & 0.027 & 5.7159 & 0.0407 & 0.0158 & 0.0002 & 94.4 & 10.5270 & 0.0752 & 0.11637 & 0.00071 & 0.2515 & 0.0461 & 1.07 & 0.20 \\
\hline 6000 & 0.9891 & 6.919 & 0.044 & 6.6340 & 0.0422 & 0.0256 & 0.0008 & 102.5 & 12.2254 & 0.0782 & 0.09165 & 0.00070 & -0.1722 & 0.2498 & -0.73 & 1.06 \\
\hline 9000 & 1.0000 & 10.648 & 0.084 & 8.4400 & 0.0639 & 0.0378 & 0.0027 & 99.3 & 15.5719 & 0.1186 & 0.09668 & 0.00136 & 0.0742 & 0.7869 & 0.31 & 3.34 \\
\hline
\end{tabular}




\begin{tabular}{|c|c|c|c|c|c|c|c|c|c|c|c|c|c|c|c|c|}
\hline \multicolumn{8}{|c|}{ UAF120-01 05JDDS01 HO\#4 } & \multicolumn{9}{|c|}{ Weighted average of J from standards $=0.002351+/-0.000011$} \\
\hline $\begin{array}{l}\text { Laser } \\
(\mathrm{mW})\end{array}$ & $\begin{array}{l}\text { Cum. } \\
{ }^{39} \mathrm{Ar} \\
\end{array}$ & $\begin{array}{l}{ }^{40} \mathrm{Ar} /{ }^{39} \mathrm{Ar} \\
\text { measured }\end{array}$ & \pm & $\begin{array}{l}{ }^{37} \mathrm{Ar} /{ }^{39} \mathrm{Ar} \\
\text { measured }\end{array}$ & \pm & $\begin{array}{l}{ }^{36} \mathrm{Ar} /{ }^{39} \mathrm{Ar} \\
\text { measured }\end{array}$ & \pm & $\begin{array}{c}\% \text { Atm. } \\
{ }^{40} \mathrm{Ar}\end{array}$ & $\mathrm{Ca} / \mathrm{K}$ & \pm & $\mathrm{Cl} / \mathrm{K}$ & \pm & ${ }^{40} \mathrm{Ar}^{*} /{ }^{39} \mathrm{Ar}_{\mathrm{K}}$ & \pm & $\begin{array}{l}\text { Age } \\
(\mathrm{Ma})\end{array}$ & $\begin{array}{c} \pm \\
(\mathrm{Ma}) \\
\end{array}$ \\
\hline 1000 & 0.1039 & 2.747 & 0.018 & 1.7644 & 0.0129 & 0.0090 & 0.0003 & 93.2 & 3.2411 & 0.0237 & 0.00464 & 0.00007 & 0.1843 & 0.0919 & 0.78 & 0.39 \\
\hline 2000 & 0.2731 & 1.406 & 0.008 & 1.1884 & 0.0072 & 0.0049 & 0.0001 & 98.8 & 2.1822 & 0.0132 & 0.00875 & 0.00009 & 0.0169 & 0.0316 & 0.07 & 0.13 \\
\hline 3000 & 0.4511 & 4.825 & 0.028 & 4.4266 & 0.0263 & 0.0166 & 0.0001 & 95.1 & 8.1457 & 0.0486 & 0.11424 & 0.00074 & 0.2374 & 0.0405 & 1.01 & 0.17 \\
\hline 5000 & 0.8463 & 4.504 & 0.029 & 5.4193 & 0.0366 & 0.0157 & 0.0001 & 94.3 & 9.9789 & 0.0677 & 0.11704 & 0.00091 & 0.2556 & 0.0292 & 1.08 & 0.12 \\
\hline 9000 & 1.0000 & 5.439 & 0.035 & 6.3476 & 0.0421 & 0.0189 & 0.0003 & 94.5 & 11.6952 & 0.0779 & 0.11226 & 0.00076 & 0.2978 & 0.0797 & 1.26 & 0.34 \\
\hline Integrated & & 4.000 & 0.013 & 4.2921 & 0.0155 & 0.0138 & 0.0001 & 94.7 & 7.8974 & 0.0286 & 0.08581 & 0.00037 & 0.2111 & 0.0213 & 0.89 & 0.09 \\
\hline
\end{tabular}

\begin{tabular}{|c|c|c|c|c|c|c|c|c|c|c|c|c|c|c|c|c|}
\hline \multicolumn{8}{|c|}{ UAF120-01 05JDDS01 HO\#5 } & \multicolumn{9}{|c|}{ Weighted average of $\mathrm{J}$ from standards $=0.002351+/-0.000011$} \\
\hline $\begin{array}{l}\text { Laser } \\
(\mathrm{mW})\end{array}$ & $\begin{array}{l}\text { Cum. } \\
{ }^{3 y} \mathrm{Ar}\end{array}$ & $\begin{array}{l}{ }^{40} \mathrm{Ar} /{ }^{39} \mathrm{Ar} \\
\text { measured }\end{array}$ & \pm & $\begin{array}{l}{ }^{37} \mathrm{Ar}{ }^{39} \mathrm{Ar} \\
\text { measured }\end{array}$ & \pm & $\begin{array}{l}{ }^{36} \mathrm{Ar}{ }^{39} \mathrm{Ar} \\
\text { measured }\end{array}$ & \pm & $\begin{array}{l}\% \text { Atm. } \\
{ }^{40} \mathrm{Ar}\end{array}$ & $\mathrm{Ca} / \mathrm{K}$ & \pm & $\mathrm{Cl} / \mathrm{K}$ & \pm & ${ }^{40} \mathrm{Ar} * /^{39} \mathrm{Ar}$ & \pm & $\begin{array}{r}\text { Age } \\
(\mathrm{Ma}) \\
\end{array}$ & $\begin{array}{c} \pm \\
\text { (Ma) } \\
\end{array}$ \\
\hline 1000 & 0.0181 & 10.447 & 0.077 & 3.4102 & 0.0302 & 0.0352 & 0.0015 & $\overline{97.2}$ & 6.2711 & 0.0557 & 0.01020 & 0.00037 & 0.2878 & 0.4385 & 1.22 & 1.86 \\
\hline 2000 & 0.1145 & 1.734 & 0.012 & 1.6866 & 0.0124 & 0.0060 & 0.0003 & 96.6 & 3.0981 & 0.0227 & 0.00406 & 0.00009 & 0.0580 & 0.0778 & 0.25 & 0.33 \\
\hline 3000 & 0.2224 & 1.623 & 0.014 & 1.3064 & 0.0114 & 0.0054 & 0.0003 & 93.8 & 2.3991 & 0.0210 & 0.01143 & 0.00015 & 0.0989 & 0.0821 & 0.42 & 0.35 \\
\hline 5000 & 0.6288 & 3.853 & 0.026 & 4.6597 & 0.0318 & 0.0132 & 0.0002 & 93.1 & 8.5760 & 0.0587 & 0.10679 & 0.00080 & 0.2639 & 0.0570 & 1.12 & 0.24 \\
\hline 9000 & 1.0000 & 5.899 & 0.037 & 6.2972 & 0.0396 & 0.0209 & 0.0002 & 97.2 & 11.6020 & 0.0733 & 0.12568 & 0.00082 & 0.1658 & 0.0637 & 0.70 & 0.27 \\
\hline Integrated & & 4.289 & 0.017 & 4.5984 & 0.0187 & 0.0149 & 0.0001 & 95.5 & 8.4628 & 0.0346 & 0.09186 & 0.00041 & 0.1903 & 0.0360 & 0.81 & 0.15 \\
\hline
\end{tabular}

\begin{tabular}{|c|c|c|c|c|c|c|c|c|c|c|c|c|c|c|c|c|}
\hline \multicolumn{8}{|c|}{ UAF120-01 05JDDS01 HO\#6 } & \multicolumn{9}{|c|}{ Weighted average of $\mathrm{J}$ from standards $=0.002351+/-0.000011$} \\
\hline $\begin{array}{l}\text { Laser } \\
(\mathrm{mW})\end{array}$ & ${ }^{\mathrm{C} u m} \mathrm{Ar}$. & $\begin{array}{l}{ }^{40} \mathrm{Ar} / r^{30} \mathrm{Ar} \\
\text { measured }\end{array}$ & \pm & $\begin{array}{l}{ }^{37} \mathrm{Ar} l^{39} \mathrm{Ar} \\
\text { measured }\end{array}$ & \pm & $\begin{array}{l}{ }^{36} \mathrm{Ar} r^{39} \mathrm{Ar} \\
\text { measured }\end{array}$ & \pm & $\begin{array}{l}\% \mathrm{Atm} . \\
{ }^{40} \mathrm{Ar}\end{array}$ & $\mathrm{Ca} / \mathrm{K}$ & \pm & $\mathrm{Cl/K}$ & \pm & ${ }^{40} \mathrm{Ar} *{ }^{30} \mathrm{Ar}$ & \pm & $\begin{array}{l}\text { Age } \\
\text { (Ma) }\end{array}$ & $\begin{array}{c} \pm \\
(\mathrm{Ma})\end{array}$ \\
\hline 1000 & 0.0490 & 6.329 & 0.046 & 3.1433 & 0.0237 & 0.0220 & 0.0005 & 99.4 & 5.7794 & 0.0436 & 0.00945 & 0.00016 & 0.0377 & 0.1474 & 0.16 & 0.63 \\
\hline 2000 & 0.1733 & 2.234 & 0.012 & 2.4110 & 0.0131 & 0.0081 & 0.0002 & 100.6 & 4.4308 & 0.0240 & 0.02463 & 0.00022 & -0.0140 & 0.0558 & -0.06 & 0.24 \\
\hline 3000 & 0.3489 & 4.043 & 0.024 & 5.0261 & 0.0459 & 0.0143 & 0.0002 & 95.5 & 9.2525 & 0.0847 & 0.11598 & 0.00114 & 0.1830 & 0.0715 & 0.78 & 0.30 \\
\hline 5000 & 0.7048 & 4.347 & 0.029 & 5.4448 & 0.0391 & 0.0150 & 0.0002 & 93.2 & 10.0261 & 0.0723 & 0.12233 & 0.00095 & 0.2939 & 0.0523 & 1.25 & 0.22 \\
\hline 9000 & 1.0000 & 4.458 & 0.028 & 5.7404 & 0.0391 & 0.0156 & 0.0002 & 94.6 & 10.5723 & 0.0722 & 0.10980 & 0.00078 & 0.2401 & 0.0518 & 1.02 & 0.22 \\
\hline Integrated & & 4.161 & 0.014 & 4.9694 & 0.0192 & 0.0146 & 0.0001 & 95.0 & 9.1478 & 0.0355 & 0.09984 & 0.00043 & 0.2077 & 0.0290 & 0.88 & 0.12 \\
\hline
\end{tabular}

\begin{tabular}{|c|c|c|c|c|c|c|c|c|c|c|c|c|c|c|c|c|}
\hline \multicolumn{8}{|c|}{ UAF120-01 05JDDS01 HO\#7 } & \multicolumn{9}{|c|}{ Weighted average of $\mathrm{J}$ from standards $=0.002351+/-0.000011$} \\
\hline $\begin{array}{l}\text { Laser } \\
(\mathrm{mW})\end{array}$ & $\begin{array}{l}\text { Cum. } \\
{ }^{34} \mathrm{Ar}\end{array}$ & $\begin{array}{l}{ }^{40} \mathrm{Ar} r^{39} \mathrm{Ar} \\
\text { measured }\end{array}$ & \pm & $\begin{array}{l}{ }^{37} \mathrm{Ar} r^{39} \mathrm{Ar} \\
\text { measured }\end{array}$ & \pm & $\begin{array}{l}{ }^{36} \mathrm{Ar} r^{39} \mathrm{Ar} \\
\text { measured }\end{array}$ & \pm & $\begin{array}{c}\text { \% Atm. } \\
{ }^{40} \mathrm{Ar}\end{array}$ & $\mathrm{Ca} / \mathrm{K}$ & \pm & $\mathrm{Cl} / \mathrm{K}$ & \pm & ${ }^{40} \mathrm{Ar}^{*} /{ }^{39} \mathrm{Ar}_{\mathrm{K}}$ & \pm & $\begin{array}{l}\text { Age } \\
(\mathrm{Ma})\end{array}$ & $\begin{array}{c} \pm \\
(\mathrm{Ma}) \\
\end{array}$ \\
\hline 1000 & 0.0725 & 5.610 & 0.063 & 3.3186 & 0.0368 & 0.0184 & 0.0004 & 92.7 & 6.1024 & 0.0678 & 0.00657 & 0.00017 & 0.4063 & 0.1146 & 1.72 & 0.49 \\
\hline 2000 & 0.2855 & 1.463 & 0.009 & 1.6196 & 0.0106 & 0.0050 & 0.0002 & 94.3 & 2.9749 & 0.0195 & 0.00632 & 0.00008 & 0.0811 & 0.0431 & 0.34 & 0.18 \\
\hline 3000 & 0.4509 & 4.621 & 0.028 & 4.2000 & 0.0280 & 0.0157 & 0.0002 & 93.8 & 7.7276 & 0.0517 & 0.09333 & 0.00058 & 0.2853 & 0.0692 & 1.21 & 0.29 \\
\hline 5000 & 0.7891 & 4.465 & 0.027 & 5.1024 & 0.0331 & 0.0156 & 0.0002 & 95.1 & 9.3935 & 0.0612 & 0.10199 & 0.00070 & 0.2194 & 0.0508 & 0.93 & 0.22 \\
\hline 9000 & 1.0000 & 6.384 & 0.040 & 6.9573 & 0.0463 & 0.0219 & 0.0002 & 93.4 & 12.8237 & 0.0856 & 0.11304 & 0.00085 & 0.4217 & 0.0493 & 1.79 & 0.21 \\
\hline Integrated & & 4.341 & 0.014 & 4.4755 & 0.0154 & 0.0149 & 0.0001 & 94.1 & 8.2360 & 0.0284 & 0.07560 & 0.00030 & 0.2571 & 0.0262 & 1.09 & 0.11 \\
\hline
\end{tabular}


Table B2. ${ }^{40} \mathrm{Ar} /{ }^{39} \mathrm{Ar}$ spectra and step-heating data for sample 2005RN269A. Map location “A1,” sheet RI 2006-2. Plateau age of $37.4 \pm 0.3 \mathrm{Ma}$.
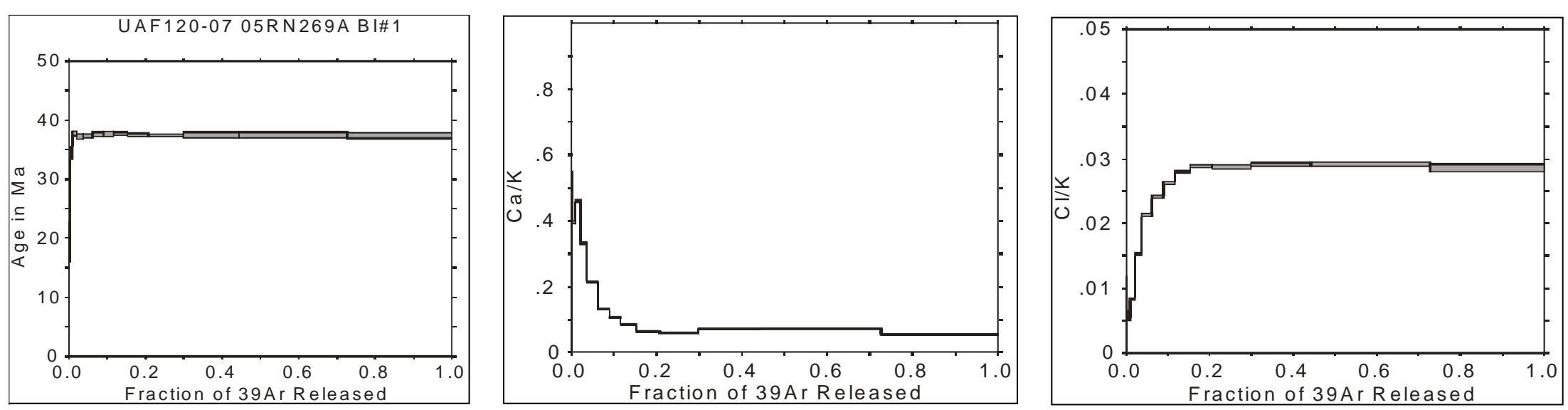

\begin{tabular}{|c|c|c|c|c|c|c|c|c|c|c|c|c|c|c|c|c|}
\hline \multicolumn{8}{|c|}{ UAF120-07 05RN269A BI\#1 } & \multicolumn{9}{|c|}{ Weighted average of $\mathrm{J}$ from standards $=0.002351 \pm 0.000011$} \\
\hline $\begin{array}{l}\text { Laser } \\
(\mathrm{mW})\end{array}$ & $\begin{array}{l}{ }^{\text {Cum. }} \text {. } \\
{ }^{39} .\end{array}$ & $\begin{array}{l}{ }^{40} \mathrm{Ar} r^{39} \mathrm{Ar} \\
\text { measured }\end{array}$ & \pm & $\begin{array}{l}{ }^{37} \mathrm{Ar}{ }^{39} \mathrm{Ar} \\
\text { measured }\end{array}$ & \pm & $\begin{array}{l}{ }^{36} \mathrm{Ar}{ }^{39} \mathrm{Ar} \\
\text { measured }\end{array}$ & \pm & $\begin{array}{l}\% \mathrm{Atm} . \\
{ }^{40} \mathrm{Ar}\end{array}$ & $\mathrm{Ca} / \mathrm{K}$ & \pm & $\mathrm{Cl/K}$ & \pm & ${ }^{40} \mathrm{Ar}^{*} /{ }^{39} \mathrm{Ar}$ & \pm & $\begin{array}{l}\text { Age } \\
\text { (Ma) }\end{array}$ & $\begin{array}{c} \pm \\
\text { (Ma) }\end{array}$ \\
\hline 300 & 0.0012 & 52.709 & 0.648 & 0.2735 & 0.0077 & 0.1647 & 0.0049 & 92.3 & 0.5019 & 0.0141 & 0.01113 & 0.00068 & 4.0354 & 1.3465 & 17.0 & 5.7 \\
\hline 500 & 0.0030 & 25.981 & 0.208 & 0.2934 & 0.0057 & 0.0730 & 0.0022 & 83.0 & 0.5385 & 0.0104 & 0.00597 & 0.00047 & 4.4150 & 0.6368 & 18.6 & 2.7 \\
\hline 900 & 0.0211 & 10.674 & 0.051 & 0.2504 & 0.0018 & 0.0057 & 0.0003 & 15.6 & 0.4595 & 0.0034 & 0.00837 & 0.00015 & 8.9845 & 0.1028 & 37.7 & 0.4 \\
\hline 1100 & 0.0367 & 10.026 & 0.057 & 0.1810 & 0.0014 & 0.0039 & 0.0003 & 11.3 & 0.3321 & 0.0026 & 0.01527 & 0.00016 & 8.8637 & 0.1147 & 37.2 & 0.5 \\
\hline 1400 & 0.0619 & 9.492 & 0.061 & 0.1174 & 0.0008 & 0.0020 & 0.0002 & 6.0 & 0.2155 & 0.0015 & 0.02132 & 0.00019 & 8.8924 & 0.0871 & 37.3 & 0.4 \\
\hline 1700 & 0.0888 & 9.320 & 0.056 & 0.0709 & 0.0007 & 0.0012 & 0.0002 & 3.6 & 0.1301 & 0.0013 & 0.02413 & 0.00022 & 8.9575 & 0.0788 & 37.6 & 0.3 \\
\hline 2000 & 0.1157 & 9.257 & 0.055 & 0.0577 & 0.0006 & 0.0009 & 0.0003 & 2.8 & 0.1059 & 0.0010 & 0.02631 & 0.00020 & 8.9688 & 0.1137 & 37.6 & 0.5 \\
\hline 3000 & 0.2068 & 9.085 & 0.056 & 0.0353 & 0.0004 & 0.0005 & 0.0001 & 1.5 & 0.0648 & 0.0007 & 0.02886 & 0.00022 & 8.9238 & 0.0641 & 37.5 & 0.3 \\
\hline 3500 & 0.2988 & 9.013 & 0.057 & 0.0325 & 0.0003 & 0.0003 & 0.0001 & 0.8 & 0.0597 & 0.0005 & 0.02875 & 0.00032 & 8.9148 & 0.0595 & 37.4 & 0.3 \\
\hline 4000 & 0.4430 & 9.036 & 0.115 & 0.0386 & 0.0003 & 0.0003 & 0.0000 & 0.9 & 0.0708 & 0.0005 & 0.02914 & 0.00025 & 8.9253 & 0.1146 & 37.5 & 0.5 \\
\hline 6000 & 0.7268 & 9.013 & 0.121 & 0.0398 & 0.0004 & 0.0002 & 0.0000 & 0.6 & 0.0730 & 0.0007 & 0.02920 & 0.00028 & 8.9289 & 0.1209 & 37.5 & 0.5 \\
\hline 9000 & 1.0000 & 9.005 & 0.124 & 0.0295 & 0.0006 & 0.0003 & 0.0000 & 0.8 & 0.0541 & 0.0011 & 0.02858 & 0.00062 & 8.9020 & 0.1245 & 37.4 & 0.5 \\
\hline Integrated & & 9.193 & 0.052 & 0.0459 & 0.0002 & 0.0009 & 0.0000 & 2.8 & 0.0843 & 0.0004 & 0.02783 & 0.00019 & 8.9037 & 0.0518 & 37.4 & 0.3 \\
\hline
\end{tabular}



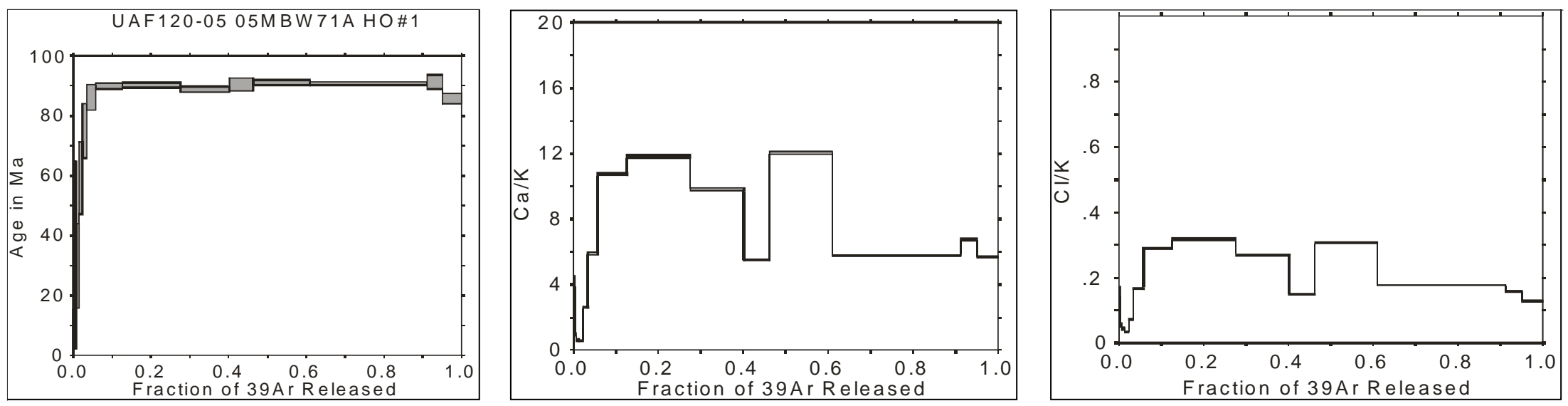

\begin{tabular}{|c|c|c|c|c|c|c|c|c|c|c|c|c|c|c|c|c|}
\hline \multicolumn{8}{|c|}{ UAF120-05 05MBW71A HO\#1 } & \multicolumn{9}{|c|}{ Weighted average of $\mathrm{J}$ from standards $=0.002351 \pm 0.000011$} \\
\hline $\begin{array}{l}\text { Laser } \\
(\mathrm{mW})\end{array}$ & $\begin{array}{l}\text { Cum. } \\
{ }^{39} \mathrm{Ar}\end{array}$ & $\begin{array}{l}{ }^{40} \mathrm{Ar} /{ }^{39} \mathrm{Ar} \\
\text { measured }\end{array}$ & \pm & $\begin{array}{l}{ }^{37} \mathrm{Ar}{ }^{39} \mathrm{Ar} \\
\text { measured }\end{array}$ & \pm & $\begin{array}{l}{ }^{36} \mathrm{Ar}{ }^{39} \mathrm{Ar} \\
\text { measured }\end{array}$ & \pm & $\begin{array}{l}\% \mathrm{Atm} . \\
{ }^{40} \mathrm{Ar}\end{array}$ & $\mathrm{Ca} / \mathrm{K}$ & \pm & $\mathrm{Cl} / \mathrm{K}$ & \pm & ${ }^{40} \mathrm{Ar}^{*} /^{39} \mathrm{Ar}_{\mathrm{K}}$ & \pm & $\begin{array}{l}\text { Age } \\
\text { (Ma) }\end{array}$ & $\begin{array}{c} \pm \\
\text { (Ma) }\end{array}$ \\
\hline 300 & 0.0019 & 277.139 & 14.935 & 2.2942 & 0.1636 & 0.9840 & 0.0775 & 104.9 & 4.2158 & 0.3010 & 0.15751 & 0.01312 & -13.5122 & 16.7828 & -58.2 & 73.5 \\
\hline 500 & 0.0061 & 71.244 & 2.194 & 0.5362 & 0.0500 & 0.2141 & 0.0262 & 88.8 & 0.9841 & 0.0918 & 0.05534 & 0.00517 & 7.9943 & 7.5258 & 33.6 & 31.3 \\
\hline 700 & 0.0138 & 27.926 & 0.561 & 0.3353 & 0.0303 & 0.0704 & 0.0115 & 74.5 & 0.6153 & 0.0556 & 0.04364 & 0.00293 & 7.1207 & 3.3918 & 30.0 & 14.2 \\
\hline 900 & 0.0223 & 26.692 & 0.419 & 0.3209 & 0.0259 & 0.0423 & 0.0099 & 46.8 & 0.5889 & 0.0475 & 0.03333 & 0.00204 & 14.2006 & 2.9370 & 59.2 & 12.1 \\
\hline 1100 & 0.0340 & 28.398 & 0.387 & 1.4267 & 0.0304 & 0.0353 & 0.0075 & 36.4 & 2.6201 & 0.0558 & 0.07231 & 0.00226 & 18.0489 & 2.2148 & 75.0 & 9.0 \\
\hline 1400 & 0.0571 & 26.937 & 0.268 & 3.2144 & 0.0349 & 0.0215 & 0.0034 & 22.8 & 5.9104 & 0.0644 & 0.16680 & 0.00239 & 20.8288 & 1.0285 & 86.2 & 4.2 \\
\hline 1700 & 0.1257 & 23.740 & 0.119 & 5.8310 & 0.0396 & 0.0084 & 0.0008 & 8.6 & 10.7399 & 0.0732 & 0.28955 & 0.00173 & 21.7550 & 0.2559 & 90.0 & 1.0 \\
\hline 2000 & 0.2762 & 22.628 & 0.159 & 6.4207 & 0.0475 & 0.0046 & 0.0004 & 3.9 & 11.8306 & 0.0880 & 0.31790 & 0.00238 & 21.8175 & 0.1983 & 90.2 & 0.8 \\
\hline 2500 & 0.4017 & 22.823 & 0.175 & 5.3346 & 0.0444 & 0.0060 & 0.0005 & 6.1 & 9.8224 & 0.0820 & 0.26967 & 0.00208 & 21.4845 & 0.2246 & 88.9 & 0.9 \\
\hline 3000 & 0.4631 & 24.576 & 0.176 & 3.0021 & 0.0244 & 0.0099 & 0.0018 & 11.0 & 5.5193 & 0.0449 & 0.14982 & 0.00152 & 21.8885 & 0.5443 & 90.5 & 2.2 \\
\hline 3500 & 0.6099 & 23.045 & 0.161 & 6.5434 & 0.0500 & 0.0053 & 0.0005 & 4.7 & 12.0577 & 0.0924 & 0.30671 & 0.00220 & 22.0363 & 0.2136 & 91.1 & 0.9 \\
\hline 4000 & 0.9125 & 22.303 & 0.104 & 3.1604 & 0.0153 & 0.0021 & 0.0003 & 1.7 & 5.8109 & 0.0282 & 0.17774 & 0.00113 & 21.9396 & 0.1304 & 90.7 & 0.5 \\
\hline 6000 & 0.9501 & 22.461 & 0.152 & 3.6828 & 0.0261 & 0.0023 & 0.0019 & 1.8 & 6.7736 & 0.0482 & 0.15771 & 0.00154 & 22.0808 & 0.5828 & 91.3 & 2.4 \\
\hline 9000 & 1.0000 & 22.094 & 0.163 & 3.1037 & 0.0261 & 0.0055 & 0.0013 & 6.3 & 5.7065 & 0.0481 & 0.12992 & 0.00128 & 20.7130 & 0.4242 & 85.8 & 1.7 \\
\hline Integrated & & 23.703 & 0.056 & 4.5349 & 0.0124 & 0.0090 & 0.0003 & 9.7 & 8.3456 & 0.0229 & 0.22782 & 0.00064 & 21.4303 & 0.1054 & 88.7 & 0.6 \\
\hline
\end{tabular}


Table B3. ${ }^{40} \mathrm{Ar}{ }^{39} \mathrm{Ar}$ spectra and step-heating data for sample 2005MBW71A. Map location “A2,” sheet RI 2006-2. (a) Plateau age of 90.4 \pm 0.5 Ma—continued.
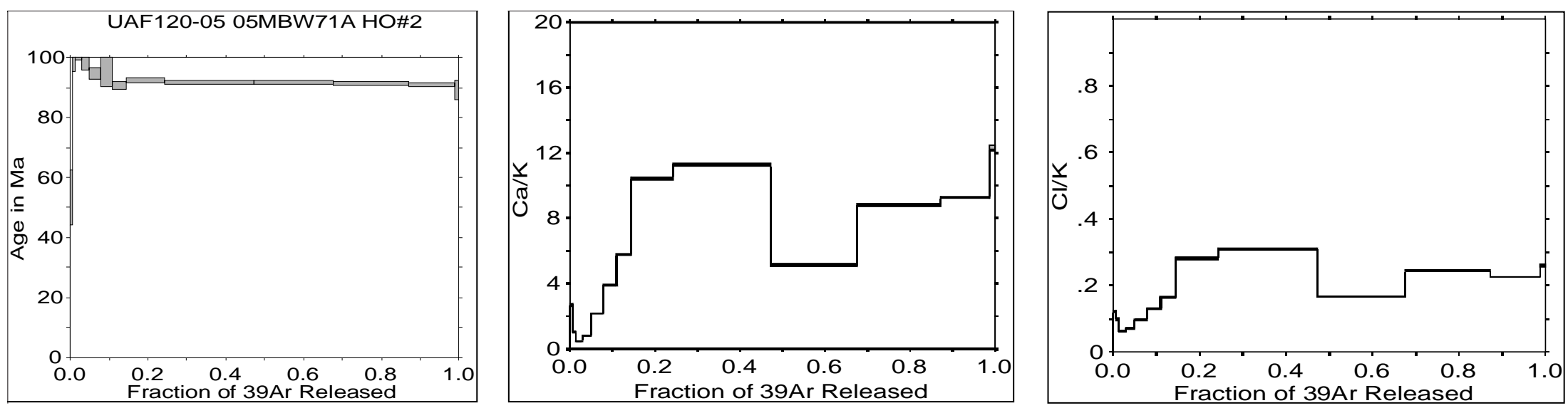

\begin{tabular}{|c|c|c|c|c|c|c|c|c|c|c|c|c|c|c|c|c|}
\hline \multicolumn{8}{|c|}{ UAF120-05 05MBW71A HO\#2 } & \multicolumn{9}{|c|}{ Weighted average of J from standards $=0.002351 \pm 0.000011$} \\
\hline $\begin{array}{l}\text { Laser } \\
(\mathrm{mW})\end{array}$ & $\begin{array}{l}{ }^{\text {Cum. }} . \\
{ }^{3 y} \text {. }\end{array}$ & $\begin{array}{l}{ }^{40} \mathrm{Ar} r^{39} \mathrm{Ar} \\
\text { measured }\end{array}$ & \pm & $\begin{array}{l}{ }^{37} \mathrm{Ar}{ }^{39} \mathrm{Ar} \\
\text { measured }\end{array}$ & \pm & $\begin{array}{l}{ }^{36} \mathrm{Ar}{ }^{39} \mathrm{Ar} \\
\text { measured }\end{array}$ & \pm & $\begin{array}{c}\% \text { Atm. } \\
{ }^{40} \mathrm{Ar}\end{array}$ & $\mathrm{Ca} / \mathrm{K}$ & \pm & $\mathrm{Cl/K}$ & \pm & ${ }^{40} \mathrm{Ar} * /^{39} \mathrm{Ark}_{\mathrm{K}}$ & \pm & $\begin{array}{r}\text { Age } \\
\text { (Ma) } \\
\end{array}$ & $\begin{array}{c} \pm \\
\text { (Ma) } \\
\end{array}$ \\
\hline 500 & 0.0065 & 92.388 & 1.728 & 1.4536 & 0.0298 & 0.2696 & 0.0089 & 86.2 & 2.6697 & 0.0549 & 0.12293 & 0.00257 & 12.8011 & 2.2442 & 53.5 & 9.2 \\
\hline 750 & 0.0135 & 7.611 & 0.255 & 0.5595 & 0.0150 & -0.0613 & 0.0091 & -239.6 & 1.0270 & 0.0275 & 0.09877 & 0.00235 & 25.7613 & 2.7245 & 106.1 & 10.9 \\
\hline 1000 & 0.0285 & 12.790 & 0.168 & 0.2520 & 0.0041 & -0.0406 & 0.0024 & -94.2 & 0.4624 & 0.0075 & 0.06370 & 0.00080 & 24.7890 & 0.7352 & 102.2 & 3.0 \\
\hline 1250 & 0.0493 & 14.228 & 0.149 & 0.4434 & 0.0062 & -0.0324 & 0.0021 & -67.7 & 0.8139 & 0.0114 & 0.07211 & 0.00091 & 23.8228 & 0.6384 & 98.3 & 2.6 \\
\hline 1500 & 0.0780 & 15.959 & 0.132 & 1.1791 & 0.0097 & -0.0233 & 0.0014 & -43.8 & 2.1651 & 0.0178 & 0.09880 & 0.00097 & 22.9264 & 0.4373 & 94.7 & 1.8 \\
\hline 1750 & 0.1093 & 16.222 & 0.130 & 2.1134 & 0.0180 & -0.0230 & 0.0046 & -42.9 & 3.8831 & 0.0331 & 0.13094 & 0.00115 & 23.1678 & 1.3796 & 95.7 & 5.6 \\
\hline 2000 & 0.1439 & 24.885 & 0.180 & 3.1346 & 0.0242 & 0.0108 & 0.0010 & 11.9 & 5.7634 & 0.0447 & 0.16468 & 0.00148 & 21.9420 & 0.3277 & 90.7 & 1.3 \\
\hline 2500 & 0.2417 & 24.061 & 0.164 & 5.6763 & 0.0430 & 0.0075 & 0.0005 & 7.4 & 10.4538 & 0.0796 & 0.28205 & 0.00211 & 22.3370 & 0.2165 & 92.3 & 0.9 \\
\hline 3500 & 0.6765 & 23.546 & 0.144 & 2.8029 & 0.0185 & 0.0054 & 0.0002 & 5.9 & 5.1524 & 0.0340 & 0.16700 & 0.00106 & 22.1796 & 0.1534 & 91.7 & 0.6 \\
\hline 4000 & 0.8716 & 22.928 & 0.129 & 4.7757 & 0.0275 & 0.0041 & 0.0003 & 3.7 & 8.7900 & 0.0507 & 0.24458 & 0.00151 & 22.1102 & 0.1601 & 91.4 & 0.7 \\
\hline 6000 & 0.9882 & 23.107 & 0.122 & 5.0403 & 0.0283 & 0.0051 & 0.0003 & 4.9 & 9.2786 & 0.0523 & 0.22674 & 0.00119 & 22.0182 & 0.1485 & 91.0 & 0.6 \\
\hline 9000 & 1.0000 & 23.629 & 0.261 & 6.6855 & 0.0738 & 0.0090 & 0.0026 & 9.1 & 12.3206 & 0.1365 & 0.26117 & 0.00322 & 21.5444 & 0.8054 & 89.1 & 3.3 \\
\hline Integrated & & 22.844 & 0.055 & 4.3699 & 0.0120 & 0.0033 & 0.0002 & 2.8 & 8.0411 & 0.0221 & 0.22713 & 0.00062 & 22.2429 & 0.0836 & 91.9 & 0.5 \\
\hline
\end{tabular}



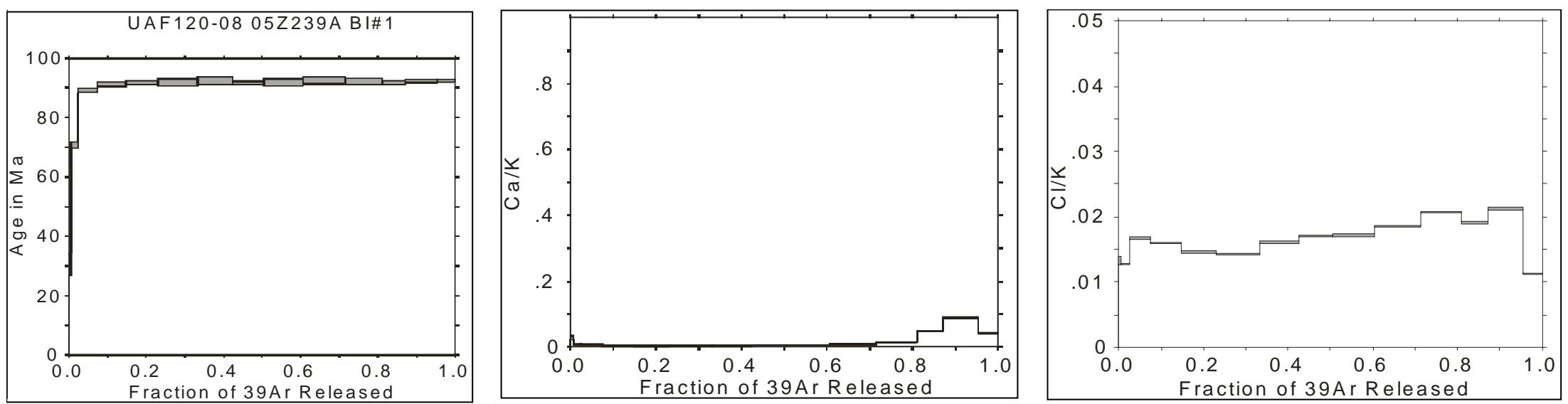

\begin{tabular}{|c|c|c|c|c|c|c|c|c|c|c|c|c|c|c|c|c|}
\hline \multicolumn{8}{|c|}{ UAF120-08 05Z239A BI\#1 } & \multicolumn{9}{|c|}{ Weighted average of $\mathrm{J}$ from standards $=0.002351 \pm 0.000011$} \\
\hline $\begin{array}{l}\text { Laser } \\
(\mathrm{mW})\end{array}$ & $\begin{array}{l}\text { Cum. } \\
{ }^{39} \mathrm{Ar}\end{array}$ & $\begin{array}{l}{ }^{40} \mathrm{Ar} r^{39} \mathrm{Ar} \\
\text { measured }\end{array}$ & \pm & $\begin{array}{l}{ }^{37} \mathrm{Ar} r^{39} \mathrm{Ar} \\
\text { measured }\end{array}$ & \pm & $\begin{array}{l}{ }^{36} \mathrm{Ar} r^{39} \mathrm{Ar} \\
\text { measured }\end{array}$ & \pm & $\begin{array}{c}\% \text { Atm. } \\
{ }^{40} \mathrm{Ar}\end{array}$ & $\mathrm{Ca} / \mathrm{K}$ & \pm & $\mathrm{Cl} / \mathrm{K}$ & \pm & ${ }^{40} \mathrm{Ar} * \beta^{39} \mathrm{Ar}_{\mathrm{K}}$ & \pm & $\begin{array}{r}\text { Age } \\
(\mathrm{Ma}) \\
\end{array}$ & $\begin{array}{c} \pm \\
(\mathrm{Ma}) \\
\end{array}$ \\
\hline 300 & 0.0060 & 29.847 & 0.401 & 0.0157 & 0.0028 & 0.0763 & 0.0029 & 75.6 & 0.0288 & 0.0052 & 0.01320 & 0.00064 & 7.2764 & 0.8596 & 30.6 & 3.6 \\
\hline 500 & 0.0247 & 25.136 & 0.210 & 0.0045 & 0.0011 & 0.0274 & 0.0007 & 32.2 & 0.0083 & 0.0020 & 0.01275 & 0.00018 & 17.0211 & 0.2539 & 70.8 & 1.0 \\
\hline 700 & 0.0739 & 22.947 & 0.130 & 0.0037 & 0.0003 & 0.0046 & 0.0003 & 6.0 & 0.0067 & 0.0006 & 0.01669 & 0.00019 & 21.5497 & 0.1450 & 89.1 & 0.6 \\
\hline 900 & 0.1480 & 22.598 & 0.185 & 0.0023 & 0.0002 & 0.0017 & 0.0002 & 2.2 & 0.0042 & 0.0004 & 0.01601 & 0.00016 & 22.0727 & 0.1931 & 91.3 & 0.8 \\
\hline 1100 & 0.2309 & 22.682 & 0.146 & 0.0018 & 0.0002 & 0.0016 & 0.0002 & 2.0 & 0.0034 & 0.0004 & 0.01457 & 0.00016 & 22.1923 & 0.1524 & 91.7 & 0.6 \\
\hline 1400 & 0.3328 & 22.916 & 0.283 & 0.0021 & 0.0002 & 0.0022 & 0.0001 & 2.9 & 0.0038 & 0.0004 & 0.01419 & 0.00013 & 22.2310 & 0.2838 & 91.9 & 1.1 \\
\hline 1700 & 0.4243 & 23.297 & 0.307 & 0.0024 & 0.0002 & 0.0030 & 0.0001 & 3.8 & 0.0043 & 0.0003 & 0.01610 & 0.00015 & 22.3857 & 0.3062 & 92.5 & 1.2 \\
\hline 2000 & 0.5048 & 22.955 & 0.126 & 0.0030 & 0.0002 & 0.0025 & 0.0002 & 3.3 & 0.0056 & 0.0004 & 0.01704 & 0.00012 & 22.1774 & 0.1373 & 91.7 & 0.6 \\
\hline 2500 & 0.6056 & 22.918 & 0.286 & 0.0033 & 0.0002 & 0.0022 & 0.0001 & 2.9 & 0.0060 & 0.0004 & 0.01709 & 0.00018 & 22.2343 & 0.2866 & 91.9 & 1.2 \\
\hline 3000 & 0.7145 & 22.838 & 0.291 & 0.0043 & 0.0002 & 0.0015 & 0.0001 & 1.9 & 0.0078 & 0.0004 & 0.01855 & 0.00014 & 22.3808 & 0.2922 & 92.5 & 1.2 \\
\hline 3500 & 0.8109 & 22.749 & 0.274 & 0.0081 & 0.0002 & 0.0015 & 0.0001 & 1.9 & 0.0149 & 0.0003 & 0.02073 & 0.00015 & 22.2902 & 0.2753 & 92.1 & 1.1 \\
\hline 4000 & 0.8714 & 22.584 & 0.153 & 0.0265 & 0.0005 & 0.0012 & 0.0002 & 1.6 & 0.0486 & 0.0009 & 0.01911 & 0.00019 & 22.1971 & 0.1589 & 91.8 & 0.6 \\
\hline 6000 & 0.9539 & 22.680 & 0.128 & 0.0479 & 0.0003 & 0.0011 & 0.0001 & 1.4 & 0.0880 & 0.0006 & 0.02120 & 0.00015 & 22.3360 & 0.1324 & 92.3 & 0.5 \\
\hline 9000 & 1.0000 & 23.056 & 0.110 & 0.0229 & 0.0004 & 0.0022 & 0.0002 & 2.9 & 0.0421 & 0.0008 & 0.01119 & 0.00014 & 22.3681 & 0.1262 & 92.4 & 0.5 \\
\hline grated & & 22.938 & 0.070 & 0.0095 & 0.0001 & 0.0029 & 0.0001 & 3.8 & 0.0175 & 0.0001 & 0.01699 & 0.00004 & 22.0405 & 0.0706 & 91.1 & 0.5 \\
\hline
\end{tabular}


Table B5. ${ }^{40} \mathrm{Ar}{ }^{39} \mathrm{Ar}$ spectra and step-heating data for sample 2005JEA30A. Map location "A4," sheet RI 2006-2. Plateau age of $92.9 \pm 0.5 \mathrm{Ma}$.
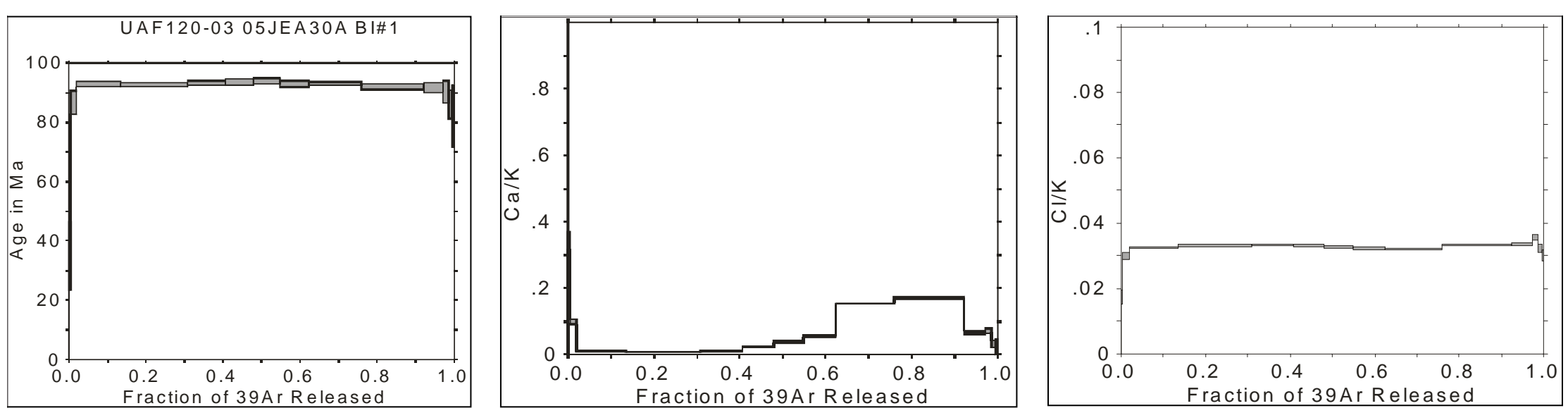

\begin{tabular}{|c|c|c|c|c|c|c|c|c|c|c|c|c|c|c|c|c|}
\hline \multicolumn{8}{|c|}{ UAF120-03 05JEA30A BI\#1 } & \multicolumn{9}{|c|}{ Weighted average of $\mathrm{J}$ from standards $=0.002351 \pm 0.000011$} \\
\hline $\begin{array}{l}\text { Laser } \\
(\mathrm{mW})\end{array}$ & $\begin{array}{l}\begin{array}{l}\text { Cum. } \\
{ }^{39} \mathrm{Ar}\end{array} \\
\end{array}$ & $\begin{array}{l}{ }^{40} \mathrm{Ar} /{ }^{39} \mathrm{Ar} \\
\text { measured }\end{array}$ & \pm & $\begin{array}{l}{ }^{37} \mathrm{Ar}{ }^{39} \mathrm{Ar} \\
\text { measured }\end{array}$ & \pm & $\begin{array}{l}{ }^{36} \mathrm{Ar} r^{39} \mathrm{Ar} \\
\text { measured }\end{array}$ & \pm & $\begin{array}{c}\% \text { Atm. } \\
{ }^{40} \mathrm{Ar}\end{array}$ & $\mathrm{Ca} / \mathrm{K}$ & \pm & $\mathrm{Cl/K}$ & \pm & ${ }^{40} \mathrm{Ar}^{*} /^{39} \mathrm{Ar}$ & \pm & $\begin{array}{r}\text { Age } \\
\text { (Ma) }\end{array}$ & $\begin{array}{c} \pm \\
(\mathrm{Ma}) \\
\end{array}$ \\
\hline 300 & 0.0045 & 28.917 & 0.696 & 0.1872 & 0.0153 & 0.0697 & 0.0094 & 71.2 & 0.3436 & 0.0281 & 0.01731 & 0.00203 & 8.3145 & 2.7460 & 34.9 & 11.4 \\
\hline 500 & 0.0196 & 30.559 & 0.317 & 0.0541 & 0.0041 & 0.0324 & 0.0032 & 31.3 & 0.0992 & 0.0075 & 0.02982 & 0.00097 & 20.9677 & 0.9688 & 86.8 & 3.9 \\
\hline 700 & 0.1345 & 24.193 & 0.174 & 0.0065 & 0.0007 & 0.0057 & 0.0004 & 7.0 & 0.0119 & 0.0012 & 0.03256 & 0.00029 & 22.4832 & 0.2006 & 92.9 & 0.8 \\
\hline 900 & 0.3082 & 23.042 & 0.155 & 0.0049 & 0.0005 & 0.0020 & 0.0003 & 2.5 & 0.0090 & 0.0008 & 0.03322 & 0.00037 & 22.4341 & 0.1722 & 92.7 & 0.7 \\
\hline 1100 & 0.4065 & 23.358 & 0.143 & 0.0071 & 0.0006 & 0.0025 & 0.0004 & 3.1 & 0.0129 & 0.0012 & 0.03320 & 0.00025 & 22.5970 & 0.1842 & 93.4 & 0.7 \\
\hline 1400 & 0.4792 & 23.821 & 0.156 & 0.0131 & 0.0011 & 0.0038 & 0.0008 & 4.7 & 0.0240 & 0.0020 & 0.03325 & 0.00041 & 22.6667 & 0.2677 & 93.7 & 1.1 \\
\hline 1700 & 0.5482 & 23.876 & 0.138 & 0.0213 & 0.0012 & 0.0038 & 0.0007 & 4.7 & 0.0392 & 0.0022 & 0.03263 & 0.00036 & 22.7264 & 0.2481 & 93.9 & 1.0 \\
\hline 2000 & 0.6234 & 23.420 & 0.176 & 0.0303 & 0.0013 & 0.0030 & 0.0007 & 3.8 & 0.0557 & 0.0023 & 0.03217 & 0.00037 & 22.5133 & 0.2699 & 93.0 & 1.1 \\
\hline 3000 & 0.9220 & 22.621 & 0.130 & 0.0924 & 0.0017 & 0.0012 & 0.0006 & 1.5 & 0.1696 & 0.0031 & 0.03336 & 0.00031 & 22.2542 & 0.2287 & 92.0 & 0.9 \\
\hline 3500 & 0.9712 & 22.568 & 0.190 & 0.0362 & 0.0022 & 0.0012 & 0.0012 & 1.5 & 0.0665 & 0.0040 & 0.03350 & 0.00041 & 22.1933 & 0.4058 & 91.7 & 1.6 \\
\hline 4000 & 0.9851 & 22.575 & 0.282 & 0.0396 & 0.0039 & 0.0024 & 0.0030 & 3.2 & 0.0726 & 0.0072 & 0.03556 & 0.00080 & 21.8332 & 0.9316 & 90.3 & 3.8 \\
\hline 6000 & 0.9955 & 22.122 & 0.246 & 0.0177 & 0.0053 & 0.0044 & 0.0040 & 5.8 & 0.0325 & 0.0098 & 0.03216 & 0.00124 & 20.8076 & 1.2031 & 86.2 & 4.9 \\
\hline 9000 & 1.0000 & 21.877 & 0.442 & 0.0109 & 0.0135 & 0.0069 & 0.0087 & 9.3 & 0.0201 & 0.0249 & 0.03025 & 0.00177 & 19.8226 & 2.6055 & 82.2 & 10.6 \\
\hline Integrated & & 23.375 & 0.051 & 0.0377 & 0.0004 & 0.0034 & 0.0002 & 4.3 & 0.0691 & 0.0007 & 0.03279 & 0.00011 & 22.3470 & 0.0768 & 92.4 & 0.5 \\
\hline
\end{tabular}



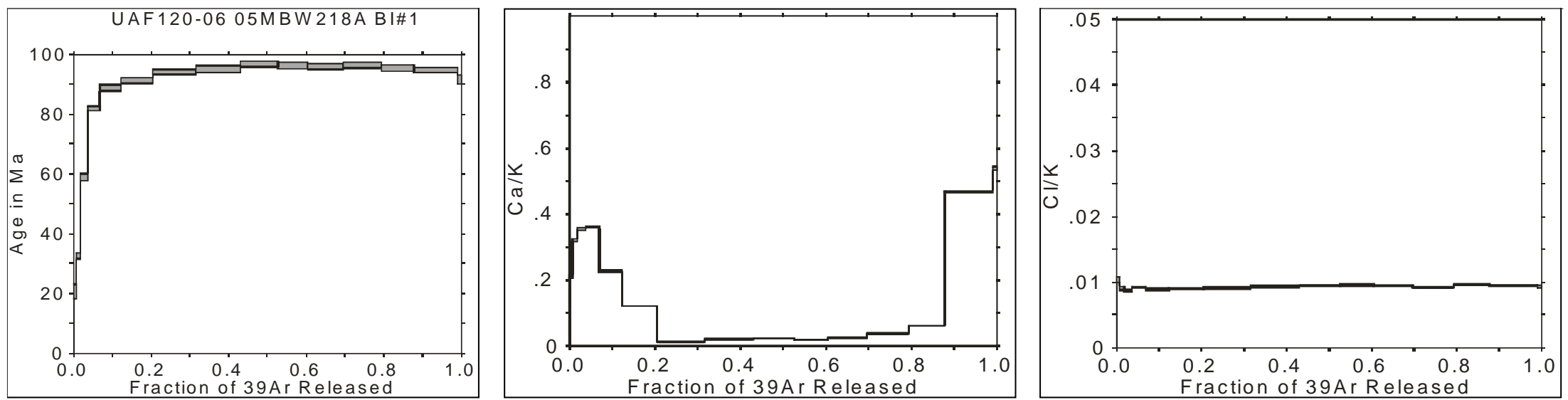

\begin{tabular}{|c|c|c|c|c|c|c|c|c|c|c|c|c|c|c|c|c|}
\hline \multicolumn{8}{|c|}{ UAF120-06 05MBW218A BI\#1 } & \multicolumn{9}{|c|}{ Weighted average of $\mathrm{J}$ from standards $=0.002351 \pm 0.000011$} \\
\hline $\begin{array}{l}\text { Laser } \\
(\mathrm{mW})\end{array}$ & ${ }_{{ }^{3 y} \mathrm{Ar}}^{\mathrm{Cu}}$ & $\begin{array}{l}{ }^{40} \mathrm{Ar} /{ }^{39} \mathrm{Ar} \\
\text { measured }\end{array}$ & \pm & $\begin{array}{l}{ }^{37} \mathrm{Ar}{ }^{39} \mathrm{Ar} \\
\text { measured }\end{array}$ & \pm & $\begin{array}{l}{ }^{36} \mathrm{Ar}{ }^{39} \mathrm{Ar} \\
\text { measured }\end{array}$ & \pm & $\begin{array}{c}\% \text { Atm. } \\
{ }^{40} \mathrm{Ar}\end{array}$ & $\mathrm{Ca} / \mathrm{K}$ & \pm & $\mathrm{Cl} / \mathrm{K}$ & \pm & ${ }^{40} \mathrm{Ar}^{4 *} l^{39} \mathrm{Ar}$ & \pm & $\begin{array}{l}\text { Age } \\
\text { (Ma) }\end{array}$ & $\begin{array}{c} \pm \\
(\mathrm{Ma}) \\
\end{array}$ \\
\hline 300 & 0.0065 & 36.166 & 0.320 & 0.1147 & 0.0028 & 0.1057 & 0.0020 & 86.4 & 0.2104 & 0.0052 & 0.01038 & 0.00045 & 4.9116 & 0.5714 & 20.7 & 2.4 \\
\hline 500 & 0.0178 & 16.500 & 0.127 & 0.1751 & 0.0016 & 0.0296 & 0.0008 & 53.0 & 0.3213 & 0.0030 & 0.00904 & 0.00028 & 7.7473 & 0.2360 & 32.6 & 1.0 \\
\hline 750 & 0.0366 & 19.486 & 0.244 & 0.1939 & 0.0020 & 0.0181 & 0.0007 & 27.4 & 0.3559 & 0.0037 & 0.00875 & 0.00020 & 14.1183 & 0.3008 & 58.9 & 1.2 \\
\hline 1000 & 0.0681 & 22.313 & 0.134 & 0.1970 & 0.0013 & 0.0085 & 0.0004 & 11.3 & 0.3615 & 0.0023 & 0.00920 & 0.00014 & 19.7775 & 0.1740 & 82.0 & 0.7 \\
\hline 1250 & 0.1227 & 22.881 & 0.257 & 0.1236 & 0.0015 & 0.0048 & 0.0002 & 6.1 & 0.2267 & 0.0027 & 0.00884 & 0.00013 & 21.4593 & 0.2548 & 88.8 & 1.0 \\
\hline 1500 & 0.2047 & 22.911 & 0.253 & 0.0666 & 0.0004 & 0.0027 & 0.0002 & 3.5 & 0.1222 & 0.0008 & 0.00895 & 0.00010 & 22.0815 & 0.2550 & 91.3 & 1.0 \\
\hline 1750 & 0.3159 & 23.176 & 0.205 & 0.0068 & 0.0002 & 0.0012 & 0.0001 & 1.6 & 0.0124 & 0.0004 & 0.00907 & 0.00010 & 22.7869 & 0.2067 & 94.1 & 0.8 \\
\hline 2000 & 0.4302 & 23.406 & 0.293 & 0.0116 & 0.0002 & 0.0012 & 0.0001 & 1.5 & 0.0213 & 0.0004 & 0.00932 & 0.00010 & 23.0154 & 0.2944 & 95.1 & 1.2 \\
\hline 2250 & 0.5266 & 23.883 & 0.240 & 0.0126 & 0.0002 & 0.0014 & 0.0001 & 1.7 & 0.0230 & 0.0003 & 0.00948 & 0.00008 & 23.4414 & 0.2429 & 96.8 & 1.0 \\
\hline 2500 & 0.6048 & 23.829 & 0.257 & 0.0104 & 0.0003 & 0.0016 & 0.0002 & 2.0 & 0.0191 & 0.0005 & 0.00955 & 0.00011 & 23.3266 & 0.2604 & 96.3 & 1.1 \\
\hline 3000 & 0.6966 & 23.835 & 0.254 & 0.0139 & 0.0002 & 0.0019 & 0.0001 & 2.4 & 0.0254 & 0.0003 & 0.00945 & 0.00009 & 23.2441 & 0.2544 & 96.0 & 1.0 \\
\hline 3500 & 0.7936 & 23.932 & 0.252 & 0.0207 & 0.0002 & 0.0019 & 0.0001 & 2.3 & 0.0380 & 0.0004 & 0.00915 & 0.00006 & 23.3481 & 0.2540 & 96.4 & 1.0 \\
\hline 4000 & 0.8775 & 23.824 & 0.254 & 0.0338 & 0.0003 & 0.0023 & 0.0001 & 2.8 & 0.0621 & 0.0005 & 0.00956 & 0.00008 & 23.1273 & 0.2544 & 95.5 & 1.0 \\
\hline 6000 & 0.9901 & 23.367 & 0.219 & 0.2548 & 0.0016 & 0.0015 & 0.0001 & 1.8 & 0.4676 & 0.0029 & 0.00949 & 0.00008 & 22.9204 & 0.2198 & 94.7 & 0.9 \\
\hline 9000 & 1.0000 & 22.970 & 0.107 & 0.2936 & 0.0034 & 0.0028 & 0.0013 & 3.5 & 0.5388 & 0.0062 & 0.00932 & 0.00024 & 22.1356 & 0.3872 & 91.5 & 1.6 \\
\hline Integrated & & 23.404 & 0.074 & 0.0666 & 0.0002 & 0.0034 & 0.0001 & 4.3 & 0.1222 & 0.0003 & 0.00929 & 0.00003 & 22.3774 & 0.0744 & 92.5 & 0.5 \\
\hline
\end{tabular}


Table B6. ${ }^{40} \mathrm{Ar} /{ }^{39} \mathrm{Ar}$ spectra and step-heating data for sample 2005MBW218A. Map location “A5,” sheet RI 2006-2. (a) Plateau age of 95.5 \pm 0.5 Ma—continued.
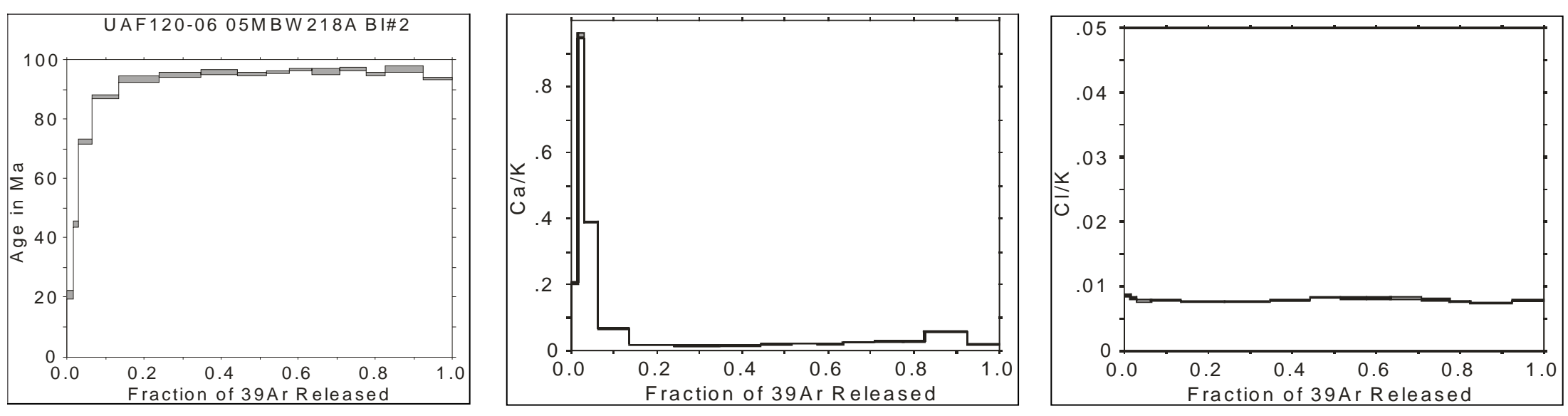

\begin{tabular}{|c|c|c|c|c|c|c|c|c|c|c|c|c|c|c|c|c|}
\hline \multicolumn{8}{|c|}{ UAF120-06 05MBW218A BI\#2 } & \multicolumn{9}{|c|}{ Weighted average of $\mathrm{J}$ from standards $=0.002351 \pm 0.000011$} \\
\hline $\begin{array}{l}\text { Laser } \\
(\mathrm{mW})\end{array}$ & $\begin{array}{l}\text { Cum. } \\
{ }^{39} \mathrm{Ar}\end{array}$ & $\begin{array}{l}{ }^{40} \mathrm{Ar} r^{39} \mathrm{Ar} \\
\text { measured }\end{array}$ & \pm & $\begin{array}{l}{ }^{37} \mathrm{Ar} r^{39} \mathrm{Ar} \\
\text { measured }\end{array}$ & \pm & $\begin{array}{l}{ }^{36} \mathrm{Ar} r^{39} \mathrm{Ar} \\
\text { measured }\end{array}$ & \pm & $\begin{array}{l}\% \text { Atm. } \\
{ }^{40} \mathrm{Ar}\end{array}$ & $\mathrm{Ca} / \mathrm{K}$ & \pm & $\mathrm{Cl} / \mathrm{K}$ & \pm & ${ }^{40} \mathrm{Ar}^{*} \beta^{39} \mathrm{Ar}$ & \pm & $\begin{array}{r}\text { Age } \\
(\mathrm{Ma}) \\
\end{array}$ & $\begin{array}{c} \pm \\
\text { (Ma) }\end{array}$ \\
\hline 300 & 0.0153 & 30.352 & 0.167 & 0.1121 & 0.0014 & 0.0859 & 0.0011 & 83.7 & 0.2056 & 0.0025 & 0.00873 & 0.00017 & 4.9437 & 0.3153 & 20.8 & 1.3 \\
\hline 500 & 0.0300 & 19.684 & 0.111 & 0.5208 & 0.0039 & 0.0307 & 0.0009 & 46.0 & 0.9558 & 0.0072 & 0.00826 & 0.00017 & 10.6209 & 0.2648 & 44.5 & 1.1 \\
\hline 750 & 0.0641 & 20.964 & 0.146 & 0.2127 & 0.0018 & 0.0119 & 0.0003 & 16.7 & 0.3904 & 0.0033 & 0.00776 & 0.00018 & 17.4358 & 0.1642 & 72.5 & 0.7 \\
\hline 1000 & 0.1356 & 22.462 & 0.139 & 0.0364 & 0.0005 & 0.0044 & 0.0002 & 5.7 & 0.0668 & 0.0008 & 0.00789 & 0.00010 & 21.1501 & 0.1460 & 87.5 & 0.6 \\
\hline 1250 & 0.2396 & 23.367 & 0.236 & 0.0095 & 0.0002 & 0.0024 & 0.0001 & 3.0 & 0.0174 & 0.0004 & 0.00766 & 0.00010 & 22.6389 & 0.2363 & 93.5 & 1.0 \\
\hline 1500 & 0.3472 & 23.773 & 0.228 & 0.0086 & 0.0002 & 0.0026 & 0.0001 & 3.2 & 0.0157 & 0.0003 & 0.00769 & 0.00009 & 22.9818 & 0.2283 & 94.9 & 0.9 \\
\hline 1750 & 0.4429 & 24.118 & 0.250 & 0.0090 & 0.0002 & 0.0030 & 0.0001 & 3.7 & 0.0166 & 0.0004 & 0.00786 & 0.00011 & 23.2071 & 0.2508 & 95.8 & 1.0 \\
\hline 2000 & 0.5159 & 24.017 & 0.157 & 0.0107 & 0.0002 & 0.0031 & 0.0002 & 3.8 & 0.0196 & 0.0004 & 0.00831 & 0.00009 & 23.0786 & 0.1603 & 95.3 & 0.6 \\
\hline 2250 & 0.5763 & 24.193 & 0.134 & 0.0117 & 0.0002 & 0.0032 & 0.0002 & 3.9 & 0.0215 & 0.0005 & 0.00825 & 0.00012 & 23.2170 & 0.1491 & 95.9 & 0.6 \\
\hline 2500 & 0.6346 & 24.360 & 0.126 & 0.0110 & 0.0003 & 0.0031 & 0.0003 & 3.8 & 0.0201 & 0.0006 & 0.00824 & 0.00011 & 23.4166 & 0.1491 & 96.7 & 0.6 \\
\hline 3000 & 0.7086 & 24.178 & 0.249 & 0.0144 & 0.0003 & 0.0030 & 0.0003 & 3.7 & 0.0264 & 0.0006 & 0.00822 & 0.00021 & 23.2523 & 0.2542 & 96.0 & 1.0 \\
\hline 3500 & 0.7758 & 24.312 & 0.160 & 0.0156 & 0.0004 & 0.0028 & 0.0002 & 3.4 & 0.0286 & 0.0007 & 0.00800 & 0.00012 & 23.4560 & 0.1650 & 96.8 & 0.7 \\
\hline 4000 & 0.8253 & 23.850 & 0.148 & 0.0157 & 0.0004 & 0.0026 & 0.0002 & 3.3 & 0.0288 & 0.0007 & 0.00769 & 0.00014 & 23.0463 & 0.1599 & 95.2 & 0.6 \\
\hline 6000 & 0.9240 & 24.606 & 0.254 & 0.0316 & 0.0003 & 0.0039 & 0.0001 & 4.6 & 0.0580 & 0.0006 & 0.00748 & 0.00007 & 23.4355 & 0.2534 & 96.7 & 1.0 \\
\hline 9000 & 1.0000 & 23.064 & 0.137 & 0.0103 & 0.0002 & 0.0012 & 0.0001 & 1.6 & 0.0189 & 0.0004 & 0.00783 & 0.00009 & 22.6695 & 0.1417 & 93.7 & 0.6 \\
\hline Integrated & & 23.791 & 0.058 & 0.0309 & 0.0001 & 0.0049 & 0.0001 & 6.1 & 0.0567 & 0.0002 & 0.00791 & 0.00003 & 22.3124 & 0.0590 & 92.2 & 0.5 \\
\hline
\end{tabular}



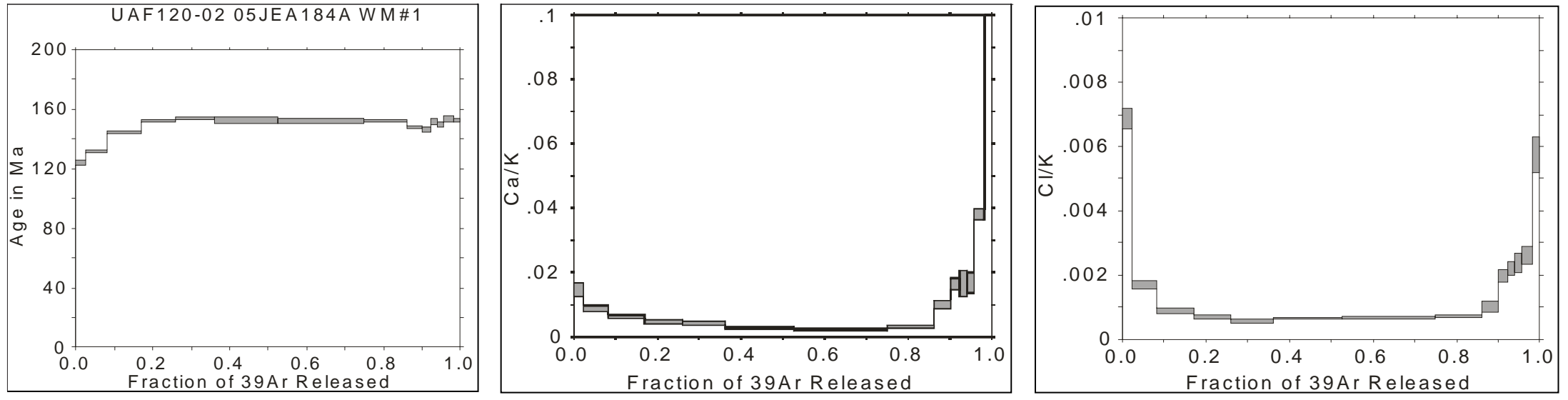

\begin{tabular}{|c|c|c|c|c|c|c|c|c|c|c|c|c|c|c|c|c|}
\hline \multicolumn{8}{|c|}{ UAF120-02 05JEA184A WM\#1 } & \multicolumn{9}{|c|}{ Weighted average of $\mathrm{J}$ from standards $=0.002351 \pm 0.000011$} \\
\hline $\begin{array}{l}\text { Laser } \\
(\mathrm{mW})\end{array}$ & $\begin{array}{l}{ }^{\text {Cum. }} \\
{ }^{3 y} \mathrm{Ar}\end{array}$ & $\begin{array}{l}{ }^{40} \mathrm{Ar} /{ }^{39} \mathrm{Ar} \\
\text { measured }\end{array}$ & \pm & $\begin{array}{l}{ }^{37} \mathrm{Ar} /{ }^{39} \mathrm{Ar} \\
\text { measured }\end{array}$ & \pm & $\begin{array}{l}{ }^{36} \mathrm{Ar} /{ }^{39} \mathrm{Ar} \\
\text { measured }\end{array}$ & \pm & $\begin{array}{c}\text { \% Atm. } \\
{ }^{40} \mathrm{Ar}\end{array}$ & $\mathrm{Ca} / \mathrm{K}$ & \pm & $\overline{\mathrm{Cl} / \mathrm{K}}$ & \pm & ${ }^{40} \mathrm{Ar}^{*} /{ }^{39} \mathrm{Ar}_{\mathrm{K}}$ & \pm & $\begin{array}{c}\text { Age } \\
(\mathrm{Ma})\end{array}$ & $\begin{array}{c} \pm \\
\text { (Ma) }\end{array}$ \\
\hline 300 & 0.0237 & 40.254 & 0.328 & 0.0080 & 0.0011 & 0.0337 & 0.0008 & 24.7 & 0.0146 & 0.0021 & 0.00688 & 0.00033 & 30.2770 & 0.3660 & 124.0 & 1.5 \\
\hline 500 & 0.0811 & 33.186 & 0.198 & 0.0048 & 0.0006 & 0.0030 & 0.0004 & 2.7 & 0.0088 & 0.0010 & 0.00168 & 0.00013 & 32.2730 & 0.2289 & 131.9 & 0.9 \\
\hline 700 & 0.1696 & 35.898 & 0.210 & 0.0034 & 0.0003 & 0.0010 & 0.0003 & 0.8 & 0.0062 & 0.0005 & 0.00089 & 0.00008 & 35.5643 & 0.2216 & 144.8 & 0.9 \\
\hline 900 & 0.2600 & 37.893 & 0.208 & 0.0026 & 0.0003 & 0.0010 & 0.0003 & 0.8 & 0.0047 & 0.0006 & 0.00069 & 0.00008 & 37.5761 & 0.2229 & 152.7 & 0.9 \\
\hline 1100 & 0.3609 & 38.213 & 0.226 & 0.0023 & 0.0004 & 0.0011 & 0.0003 & 0.8 & 0.0043 & 0.0007 & 0.00056 & 0.00007 & 37.8717 & 0.2373 & 153.9 & 0.9 \\
\hline 1400 & 0.5265 & 37.896 & 0.484 & 0.0016 & 0.0002 & 0.0009 & 0.0001 & 0.7 & 0.0028 & 0.0003 & 0.00065 & 0.00004 & 37.6150 & 0.4854 & 152.9 & 1.9 \\
\hline 1700 & 0.7494 & 37.791 & 0.412 & 0.0012 & 0.0002 & 0.0007 & 0.0001 & 0.6 & 0.0022 & 0.0004 & 0.00067 & 0.00003 & 37.5493 & 0.4130 & 152.6 & 1.6 \\
\hline 2000 & 0.8611 & 37.659 & 0.198 & 0.0017 & 0.0002 & 0.0005 & 0.0003 & 0.4 & 0.0031 & 0.0004 & 0.00072 & 0.00004 & 37.4949 & 0.2125 & 152.4 & 0.8 \\
\hline 2500 & 0.9010 & 36.877 & 0.183 & 0.0055 & 0.0007 & 0.0017 & 0.0006 & 1.4 & 0.0100 & 0.0012 & 0.00101 & 0.00017 & 36.3369 & 0.2622 & 147.9 & 1.0 \\
\hline 3000 & 0.9234 & 36.790 & 0.266 & 0.0090 & 0.0010 & 0.0026 & 0.0012 & 2.1 & 0.0165 & 0.0018 & 0.00197 & 0.00020 & 35.9828 & 0.4331 & 146.5 & 1.7 \\
\hline 3500 & 0.9408 & 36.961 & 0.239 & 0.0090 & 0.0022 & -0.0012 & 0.0016 & -0.9 & 0.0166 & 0.0041 & 0.00221 & 0.00021 & 37.2815 & 0.5264 & 151.6 & 2.1 \\
\hline 4000 & 0.9568 & 37.028 & 0.316 & 0.0091 & 0.0017 & 0.0006 & 0.0012 & 0.5 & 0.0168 & 0.0032 & 0.00238 & 0.00029 & 36.8207 & 0.4823 & 149.8 & 1.9 \\
\hline 6000 & 0.9819 & 38.392 & 0.426 & 0.0207 & 0.0009 & 0.0020 & 0.0006 & 1.5 & 0.0379 & 0.0017 & 0.00262 & 0.00028 & 37.7907 & 0.4548 & 153.5 & 1.8 \\
\hline 9000 & 1.0000 & 37.851 & 0.180 & 0.1112 & 0.0030 & 0.0010 & 0.0010 & 0.7 & 0.2040 & 0.0055 & 0.00574 & 0.00054 & 37.5448 & 0.3542 & 152.6 & 1.4 \\
\hline Integrated & & 37.402 & 0.130 & 0.0052 & 0.0001 & 0.0018 & 0.0001 & 1.4 & 0.0095 & 0.0002 & 0.00113 & 0.00002 & 36.8445 & 0.1325 & 149.8 & 0.8 \\
\hline
\end{tabular}




\section{Appendix C}

\section{Grain-mount petrology of Tertiary samples}

Grain mounts were point-counted to determine sand composition using the methodology of Decker (1985) and the "traditional" methodology of Ingersoll and others (1984). Thin sections were made from rectangular billets of sandy sample mixed with epoxy. A minimum of 250 grains were counted on each thin section on a counting grid with grid points $0.5 \mathrm{~mm}$ apart by J.E. Athey and R.L. Smith. Matrix and cement were not counted, however the composition of grains $>2 \mathrm{~mm}$ was noted. Feldspar was recognized by twinning, zoning, increased alteration, and cleavage; thin sections were not stained to determine feldspar composition. Athey and Smith communicated frequently in order to identify grain types consistently, and eight thin sections were point-counted by both geologists for comparative purposes. Consistent but acceptable differences occurred in the counts of coarse polycrystalline quartz, feldspar, and felsic volcanic rock fragments. Interpretations are based on 52 thin sections point-counted by Athey and eight thin sections point-counted by Smith (table C1). Sample locations, grain size, and a brief description of the matrix and cement are included in table C2. 
This page has intentionally been left blank. 


\begin{tabular}{|c|c|c|c|c|c|c|c|c|c|c|c|c|c|c|c|c|c|c|c|c|c|c|c|c|c|c|c|c|c|c|c|c|c|c|c|c|c|c|c|c|c|}
\hline SAMPLE NUMBER & 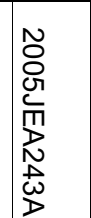 & 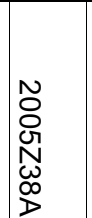 & 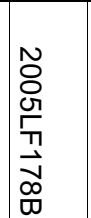 & 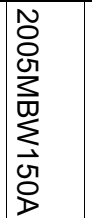 & 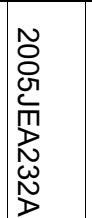 & 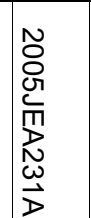 & 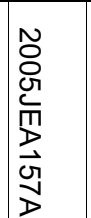 & 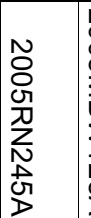 & 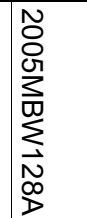 & 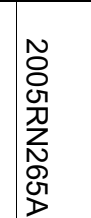 & 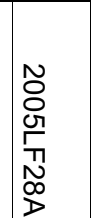 & 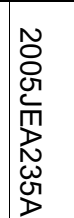 & 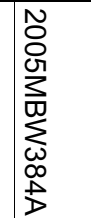 & 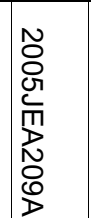 & 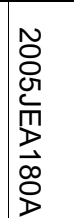 & 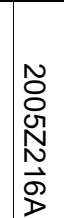 & 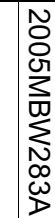 & & 莕 & 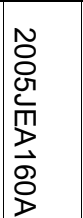 & 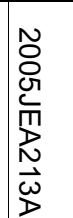 & 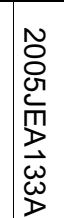 & 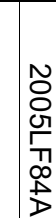 & 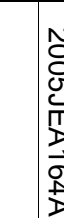 & 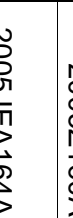 & 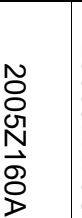 & 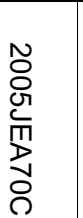 & 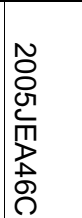 & 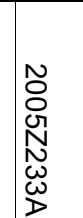 & 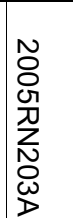 & 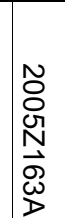 & 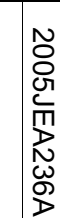 & & 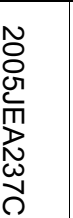 & 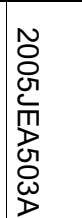 & 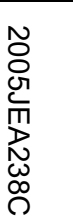 & 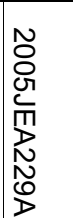 & 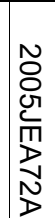 & 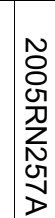 & & 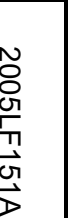 \\
\hline Cluster & $\mathrm{H} 1$ & $\mathrm{H} 1$ & $\mathrm{H}$ ? & $\mathrm{N} 1$ & $\mathrm{~N} 1$ & $\mathrm{~N} 1$ & $\mathrm{~N} 1$ & N1 & N2 & N2 & N2 & $\mathrm{N} 2$ & L1 & L1 & L1 & L1 & L1 & & 2 & L2 & L2 & L2 & L2 & & 2 & L2 & L2 & $\mathrm{L} 2$ & L2 & L2 & L2 & L2 & & $\mathrm{L} 2$ & L2 & L2 & L2 & L2 & $\mathrm{L} 2$ & & 2 \\
\hline Geologist & JEA & JEA & JEA & JEA & JEA & JEA & JEA & JEA & JEA & JEA & JEA & JEA & JEA & JEA & JEA & $\mathrm{JE} /$ & & EA. & JEA & JEA & JEA & $\mathrm{JE}$ & & & EA - & JEA & JEA & JEA & JEA & JEA & $\mathrm{JE} / \mathrm{H}$ & $\mathrm{JE}$ & EA - & JEA & JEA & RLS & JEA & JE. & & & $\mathrm{RLS}$ \\
\hline Total & 250 & 250 & 250 & 300 & 250 & 250 & 251 & 250 & 250 & 250 & 250 & 250 & 300 & 250 & 250 & 25 & & 50 & 302 & 250 & 250 & 25 & & 512 & 250 & 250 & 252 & 250 & 251 & 250 & 25 & & 50 & 250 & 250 & 250 & 250 & 25 & 25 & \begin{tabular}{l|l}
112 \\
1
\end{tabular} & 250 \\
\hline \multicolumn{42}{|l|}{ Quartz } \\
\hline \multicolumn{42}{|l|}{ Monocrystalline } \\
\hline Undulose & 10 & 8 & 64 & 27 & 18 & \begin{tabular}{|l|}
38 \\
\end{tabular} & 25 & 10 & 3 & 4 & 10 & $\varepsilon$ & \begin{tabular}{|l|l|}
3 & 32 \\
\end{tabular} & 29 & 17 & 2 & & 21 & 27 & 20 & 18 & 3 & & 13 & 22 & 25 & 16 & 26 & \begin{tabular}{|l|l|l|l|l|}
22 \\
\end{tabular} & 19 & 1 & & 20 & 8 & 19 & 18 & 24 & & & 18 & 18 \\
\hline Straight & 13 & 20 & 175 & 45 & 28 & 28 & 40 & 28 & 12 & \begin{tabular}{l|l}
2 & 19 \\
\end{tabular} & 21 & 35 & \begin{tabular}{|l|l|}
5 & 51 \\
\end{tabular} & 54 & 37 & 2 & & 33 & 57 & 62 & 57 & 5 & & 44 & 59 & 46 & 57 & 43 & 377 & 71 & 5 & & 75 & 86 & 70 & 72 & 58 & 4 & & 36 & 59 \\
\hline \multicolumn{42}{|l|}{ Polycrystalline } \\
\hline Equigranular & 9 & 10 & 2 & 2 & 8 & 4 & 10 & 4 & & 10 & 11 & 5 & 4 & 6 & 7 & 1 & & & 6 & 4 & 10 & & 9 & 4 & 4 & 10 & 6 & 8 & 16 & 1 & & 9 & 4 & 2 & 5 & 14 & 9 & & & 1 & 5 \\
\hline Foliated & & 1 & & 2 & 6 & 4 & & 1 & 1 & 15 & \begin{tabular}{|l|l|}
5 & 1 \\
\end{tabular} & 1 & 5 & 4 & & & 6 & & 6 & 1 & 8 & 3 & & 1 & & & 2 & 1 & 2 & & & 2 & & 1 & 1 & & 3 & & & & 3 \\
\hline Coarse & 10 & 8 & & 33 & 11 & 13 & 15 & 17 & 18 & \begin{tabular}{l|l}
3 & 11 \\
\end{tabular} & 12 & 15 & \begin{tabular}{|l|l|}
5 & 37 \\
\end{tabular} & 28 & 46 & 4 & & 20 & 37 & 20 & 33 & 34 & & 42 & 24 & 32 & 26 & 42 & 33 & 37 & 4 & 7 & 38 & 37 & 46 & 10 & 31 & 2 & & 23 & 19 \\
\hline Feldspar & 11 & 4 & & 4 & 7 & 9 & 8 & 19 & 4 & 4 & 8 & 12 & 7 & 17 & 8 & & 9 & 13 & 10 & 21 & 12 & 1 & & 9 & 21 & 15 & 23 & 25 & 16 & 12 & 2 & & 15 & 36 & 11 & 21 & 22 & 3 & & 13 & 33 \\
\hline \multicolumn{42}{|l|}{ Alkali } \\
\hline Unaltered K-Spar & 10 & 1 & & & & 1 & 2 & & 2 & 1 & & & 5 & 1 & & & & & 2 & 2 & 1 & & & 4 & 3 & & 2 & 1 & 4 & 2 & & 2 & 1 & 1 & 3 & & & & & 4 & \\
\hline Perthitic/Tartan & 8 & 7 & & 2 & 5 & 5 & 14 & 12 & 11 & 6 & 10 & 15 & 3 & 2 & 1 & 11 & & 8 & 5 & 5 & 7 & & 4 & 5 & 3 & 8 & 14 & 3 & 6 & 9 & 1 & 3 & 8 & 7 & 13 & 9 & 7 & 1 & & 5 & \\
\hline Graphic & & & & & & & & & & & & & & & & & & & & & 3 & 3 & 1 & & & & & & & & & & & & & & & & & & 1 \\
\hline Altered & & & & 1 & & & & & & & & & 3 & & & & & & & 1 & & 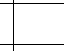 & & 1 & & & & 1 & 1 & 1 & & & & & & & & & & & \\
\hline Plagioclase & & & & & 1 & 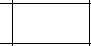 & & & & & & & & & & & & & & & & & & & & & & & 1 & & & & & & & & & & & & \\
\hline Myrmekitic & & & & & & & & & & & & & & & & & & & & & 1 & & & & & 1 & & & 2 & 1 & & & & & & 5 & & & & & \\
\hline \multicolumn{42}{|l|}{ Unzoned } \\
\hline Albite-Twin & 1 & & & 7 & 8 & 311 & 4 & 2 & 6 & 7 & 3 & 1 & 3 & 1 & 5 & & & 5 & 11 & 10 & 4 & & 8 & 5 & 13 & 9 & 12 & 1 & 2 & 7 & & 2 & 8 & 7 & 2 & 4 & 5 & & & 7 & 7 \\
\hline Carlsbad-Twins & & & & 1 & 1 & 1 & & & & & & & & & & & & & & & & & & & & & & & & & & & & & & 1 & & & & & 1 \\
\hline Chessboard & & & & 1 & & & & & & & & & & & 1 & it & & & & & & & & & & & & & & 1 & & & & & & & & & & & \\
\hline Untwinned & & 1 & & 1 & & 1 & & & 2 & 2 & & & 2 & & & & & 2 & 8 & 3 & & & 1 & 4 & 1 & & & & 2 & 3 & & & 1 & & & & & & & & \\
\hline Zoned & & & & & 1 & 1 & & & & & & & & & & & & & & & & & & & & & & & & & & & & & & & & & & & \\
\hline A-Twin & & & & 1 & & 2 & & & & & & & 3 & & & & & & & & & & & & & & & & & & & & & & & & & & & & \\
\hline Untwinned & & & & & & & & & & & & & 1 & & & & & 1 & 1 & & & & & & & & & & & & & & & & & & & & & & \\
\hline Altered & & & & 1 & & & & & 2 & 1 & 2 & & 2 & & & & & 1 & 2 & & & & 2 & & & & & & & & & 1 & & & & & & & & & \\
\hline Altered & & 2 & & 7 & 3 & 4 & 1 & & 4 & 2 & 3 & & 3 & & & & 3 & 1 & 1 & 1 & 2 & & 7 & 5 & 5 & 3 & 1 & 2 & 4 & 2 & & 4 & 1 & 5 & 2 & & & & & 1 & 2 \\
\hline Sedimentary Rock Fragment & & & & & & & & & & & & & & & & & & & & & & & & & & & & & & & & & & & & & & & & & 1 \\
\hline Chert & & & & & & & & & & & & & & & & & & & & & & & & & & & & & & & & & & & & & & & & & 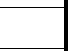 \\
\hline Common (Microcrystalline) & & 7 & 4 & 42 & 26 & 23 & 30 & 26 & 46 & \begin{tabular}{|l|l|l}
5 & 41 \\
\end{tabular} & 31 & 20 & 6 & 6 & 22 & & 7 & 9 & 11 & 9 & 18 & 32 & & 14 & 11 & 15 & 8 & 9 & 4 & 14 & 1 & 0 & 3 & 4 & 10 & 16 & 8 & & & 7 & 7 \\
\hline Radiolarian & & & & 3 & 1 & & & 2 & 7 & $7 \quad 2$ & 4 & 6 & & & 3 & & & 3 & 1 & & 3 & & & 2 & & & & & & & & & & & & & & & & & \\
\hline Foliated (Metamorphic) & & 16 & & 5 & 2 & & 4 & 2 & 5 & \begin{tabular}{|l|l|}
5 & 11 \\
\end{tabular} & 3 & 3 & 5 & 7 & 3 & 31 & & 12 & 9 & & 7 & 7 & 6 & & 1 & 2 & 3 & 1 & & 4 & if & 1 & 2 & & 3 & 7 & 11 & & & 2 & 5 \\
\hline Fibrous (Chalcedony) & & & & 3 & 1 & & & & 2 & 3 & 1 & & & & & & 1 & 1 & 2 & & & & & & 1 & & & & & 1 & & & & & & & 1 & & & 1 & \\
\hline Probable Cherty Grains & & & & 4 & & 5 & 1 & 2 & 4 & 2 & 2 & 3 & & 1 & 1 & & 2 & 4 & 3 & 6 & 2 & 2 & 1 & 1 & & 2 & 1 & & 4 & & & 2 & 2 & & & 1 & 3 & & & 1 & 1 \\
\hline Cherty Argillite & & & & 12 & 14 & 2 & 14 & 7 & 22 & \begin{tabular}{l|l}
2 & 29 \\
\end{tabular} & 14 & 22 & 3 & 1 & 2 & & & 4 & 14 & 7 & 4 & & 3 & 5 & 12 & 5 & 9 & & & 4 & & 5 & 7 & 5 & 7 & & 3 & & & 5 & 3 \\
\hline Argillite & & & & 5 & & 1 & 10 & & 15 & 6 & $\begin{array}{ll}4 \\
\end{array}$ & 16 & 1 & & 1 & & & & 8 & & & & 2 & 1 & 1 & & & & & & & 2 & 2 & & 3 & & & & & & \\
\hline Slate/Shale & & & & 3 & & 3 & 4 & 9 & & 1 & 10 & 5 & 2 & & 3 & 3 & 8 & & 2 & 1 & 2 & $=$ & & 3 & 8 & 4 & 2 & 1 & 5 & 3 & & 4 & 11 & 1 & 4 & & 2 & & & 8 & 4 \\
\hline Siltstone & & & & 8 & 13 & 3 & 15 & 9 & 8 & 9 & 16 & 12 & & & 2 & & & & 1 & 2 & 4 & t. & 1 & 1 & 3 & 6 & 3 & & & & & 5 & 6 & 1 & 1 & & 2 & & & 2 & \\
\hline Sandstone & & & & & & 4 & 1 & 5 & & & & & & 2 & 4 & & & & & & & & & & & 5 & & & & & & & 1 & & 1 & 7 & 2 & & & & 1 \\
\hline Quartz & & 2 & & & 7 & & & & 1 & 5 & \begin{tabular}{|l|l|l|l|l}
5 & 4 \\
\end{tabular} & & & & & & & & & 1 & 1 & it & 1 & & & & & & & & & & & & & 7 & & & & & 1 \\
\hline Plagioclase & & & & & & & & & & & & & & & & & & & & & & & & & 1 & & & & & & & & & & & & & & & & 2 \\
\hline Feldspar & & & & & & & & & 2 & 2 & & & & & & & & & & & & & & & & & & & & & & & & & & & & & & & 1 \\
\hline Garnet & & & & & & & & & & & & & & & & & & & & & & & & & & & & & & & & & & & & & & & & & \\
\hline Sedimentary Rock Fragment & & & & & 1 & II & & & 1 & 1 & & 1 & 1 & & & & & & & & & & & & & & & & & & & & & & & 2 & & & & & \\
\hline
\end{tabular}




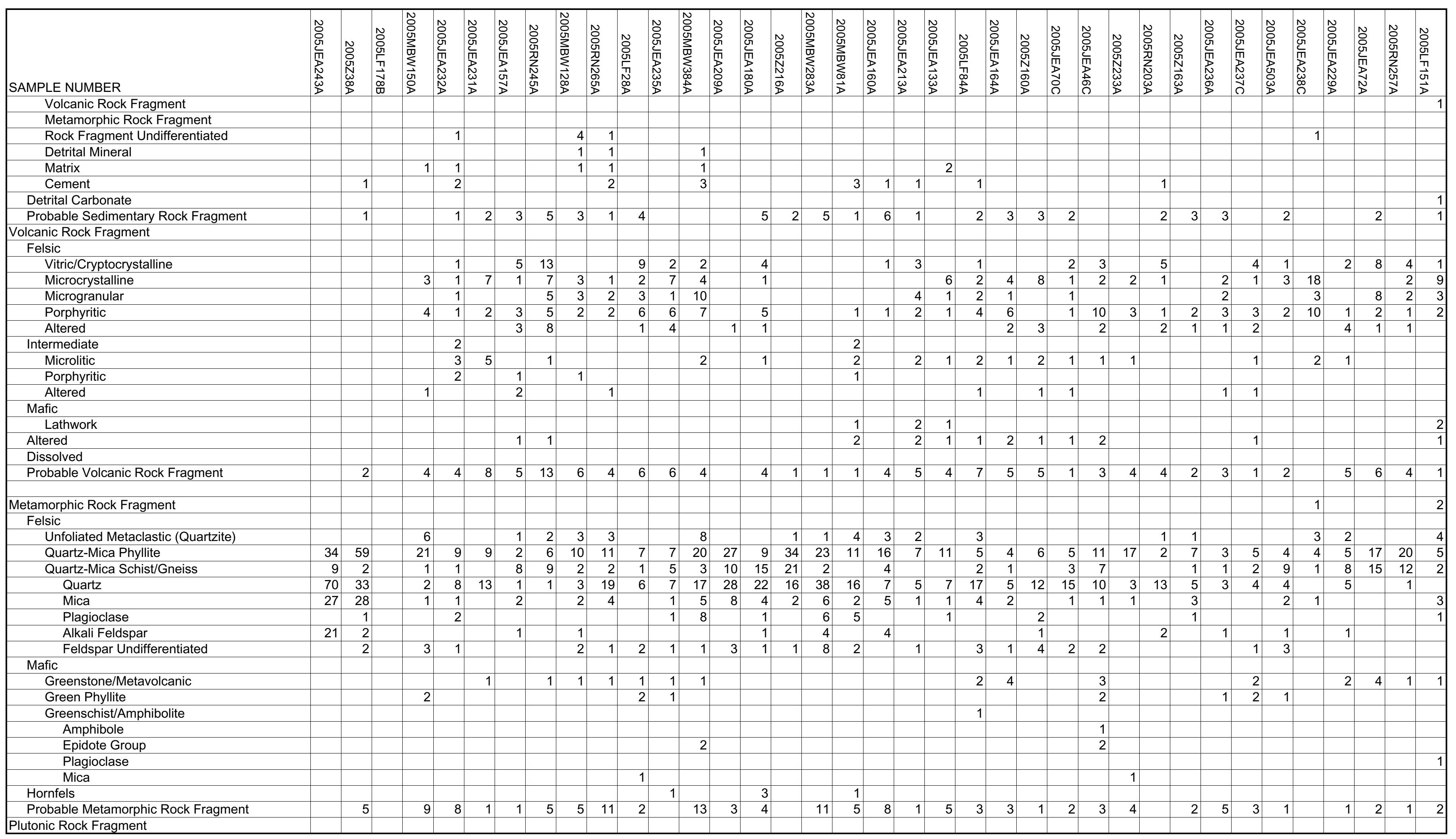




\begin{tabular}{|c|c|c|c|c|c|c|c|c|c|c|c|c|c|c|c|c|c|c|c|c|c|c|c|c|c|c|c|c|c|c|c|c|c|c|c|c|c|c|c|}
\hline SAMPLE NUMBER & 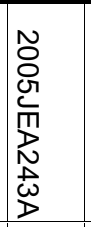 & 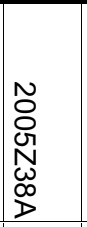 & 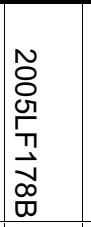 & 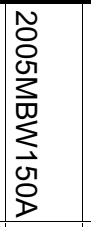 & 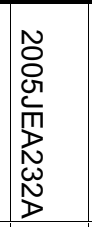 & 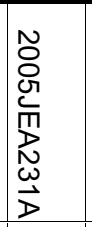 & 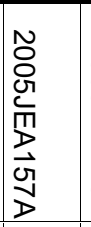 & 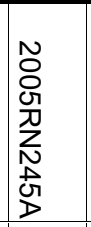 & 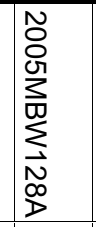 & 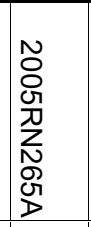 & 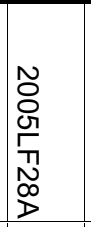 & 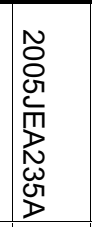 & 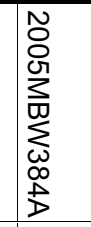 & 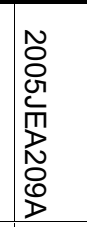 & 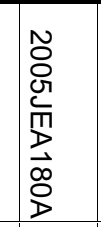 & 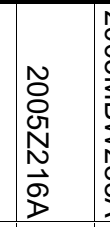 & 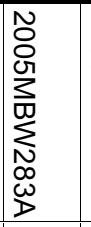 & 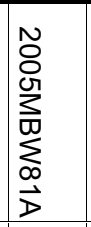 & 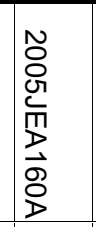 & 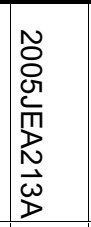 & 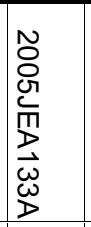 & 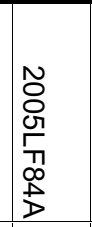 & 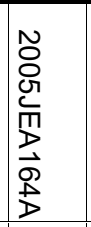 & 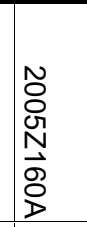 & 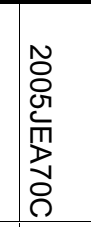 & 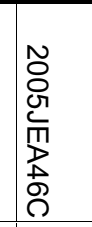 & 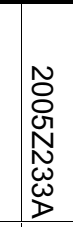 & 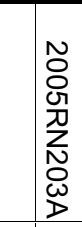 & 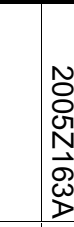 & 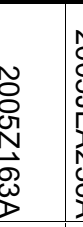 & 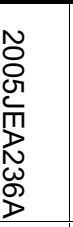 & 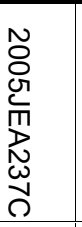 & 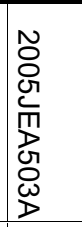 & 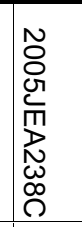 & 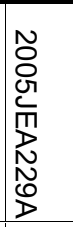 & 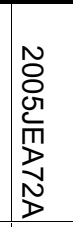 & 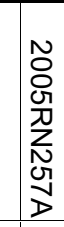 & & 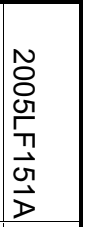 \\
\hline Felsic & & & & & & 4 & & & $5 \quad 1$ & & & $\begin{array}{l}3 \quad 2 \\
\end{array}$ & 2 & & 1 & 1 & & & 6 & 1 & & & 4 & +2 & & 1 & 1 & & & & 1 & & 3 & & & & & & 4 \\
\hline Quartz & & & & 4 & 2 & 8 & 4 & & 1 & 2 & 4 & 1 & $1 \quad 1$ & & 1 & 1 & & 2 & & 3 & 4 & 7 & 5 & 3 & 4 & 5 & 5 & 2 & 5 & 3 & 6 & 5 & 5 & 1 & 1 & 2 & 2 & & 2 \\
\hline K-Spar & & & & 2 & 2 & 4 & 2 & & 2 & 1 & 1 & 1 & 1 & & & & & 1 & 2 & 1 & & 2 & & & 4 & 2 & 2 & & 2 & & 1 & 1 & 1 & & 1 & & & & 1 \\
\hline Plagioclase & & & & 3 & 1 & 12 & & & 5 & 1 & 3 & 4 & 1 & & & & & 2 & 1 & 1 & 2 & 4 & 1 & 2 & 5 & & & 3 & 5 & 3 & 2 & & & 1 & & 1 & 1 & & 2 \\
\hline Biotite & & & & & & 1 & & & & & & & & & & & & & & & & & & & & & & & & & & & & & & & & & \\
\hline Chlorite & & & & & & & & & & & & & & & & & & & & & & & & & & & & & & & & & & 1 & & & & & \\
\hline Amphibole & & & & & & 1 & & & & & & & & & 1 & 1 & & & & & & & & & & & & & & & & & & & & & & & \\
\hline Altered & & & & 2 & & 4 & 1 & 1 & 3 & 1 & & 1 & 1 & & 1 & 1 & & & & & 1 & 2 & & 1 & 1 & 3 & 3 & & 4 & & & 1 & 3 & & & 3 & 3 & & 2 \\
\hline Intermediate & & & & & & 1 & & & & 1 & & & & & & & & & & & & 1 & & & & 1 & 1 & & & & & 1 & & & & 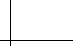 & & & 1 \\
\hline Plagioclase & & & & & & 4 & & & 1 & 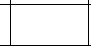 & 2 & & & & & & & 2 & & 1 & & & & & 1 & & & & & & 2 & & & & & & & & \\
\hline Amphibole & & & & & & & & & & & & & & & & & & & & 1 & & & & & & & & & & & & & & & & & & & \\
\hline Altered & & & & 2 & 6 & 6 & 1 & & & & & & 3 & & & & & 1 & 1 & 2 & & & & & 1 & & & & & & & & & & & & & & \\
\hline Mafic & & & & & & & & & & & & & & & & & & & & & & & & & & 2 & 2 & & & & & & & & & & & & \\
\hline Plagioclase & & & & & 2 & & & & & & & & & & & & & & & & & & & & & & & & & & & & & & & & & & \\
\hline Pyroxene & & & & & 8 & & & & & & & & & & & & & & & & & & & & & & & & & & & & & & & & & & \\
\hline Altered & & & & 3 & 7 & & & & 1 & 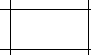 & & & 1 & & & & & 1 & 1 & & & & & & & & & & & & & & & & & & & & \\
\hline Probable Plutonic Rock Fragment & & & & 2 & 2 & 1 & 2 & 3 & 5 & & 2 & 1 & 3 & 1 & 1 & 1 & & 6 & t & 1 & 2 & 3 & & 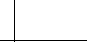 & 3 & 6 & 6 & & 2 & & 1 & & 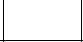 & 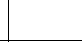 & & 1 & & & 2 \\
\hline Detrital Mineral & & & & & & & & & & & & & & 1 & 1 & & & & & & & & & & & & & & & & & & & & & & & & \\
\hline Biotite & & & & 1 & 4 & 8 & 2 & 1 & 1 & & & & & 4 & 4 & 3 & & 1 & 1 & & & & & 1 & 3 & & & & & & 1 & & & 3 & & 3 & 3 & & 3 \\
\hline White Mica & 17 & 26 & 5 & 2 & & 2 & 1 & & & 1 & & & 1 & 4 & 1 & 9 & 3 & 1 & 1 & & 3 & 4 & 3 & 4 & 2 & & & 9 & 3 & 1 & 1 & 5 & 2 & & 11 & 1 & 1 & 1 & 8 \\
\hline Chlorite & & & & & & & & & & & & & & & & & & & & & & & & & & & & & & & & & & 2 & 1 & & & & 2 \\
\hline Mica, Undifferentiated & & & & & & & & & & & & & & & & & & & & & & & & & & & & & & & 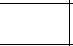 & & & 3 & & 1 & 1 & & \\
\hline Pyroxene & & & & & 1 & 1 & & & & & & & & & & & & & & 1 & & & & & & & & & & & & & & & & & & & \\
\hline Amphibole & & & & 1 & 1 & 3 & & 3 & & & & & & & & & & 1 & & & 1 & & & & 3 & 1 & 1 & & 1 & & 1 & 1 & & & 2 & 2 & 2 & & 4 \\
\hline Zircon & & 1 & & & 1 & & & & & & & & & & & & & & & & & & & & & & & & & & & & & & & & & & \\
\hline Tourmaline & & & & & & & & & & & & & & & & 5 & 1 & & & & & & & & & & & & & & & & & & & & & & \\
\hline Apatite & & & & & & & & & & & & & & & & & & & & & & & & & & & & & & & & & & & & & & & \\
\hline Epidote & & & & & 1 & & & & & & 2 & & & & & & 2 & & 3 & 2 & & 1 & & & 1 & & & & 2 & & & 2 & & 1 & & & & & 2 \\
\hline Opaque Minerals & & & & & & & & & & & & & & 1 & 1 & & 1 & & & & & & & & & & & & & & & & & & 2 & & & & \\
\hline Undifferentiated Grain & 3 & 5 & & 9 & 8 & 4 & 3 & 5 & 9 & 8 & 6 & 6 & \begin{tabular}{l|l}
6 & 15 \\
\end{tabular} & & 3 & \begin{tabular}{l|l|}
3 & 7 \\
\end{tabular} & 8 & 8 & 9 & 8 & 3 & 3 & 10 & 3 & 7 & 1 & 1 & 6 & 5 & 3 & 6 & 10 & 3 & 1 & 7 & $\varepsilon$ & & 2 & 5 \\
\hline Oversized Grain & & & & & & & & & & & & & & & & & & & & & & & & & & & & & & & & & & & & & & & \\
\hline Detrital Pebble & & & & & & & & & & & & & & & & & & & & & & & & & & & & & & & & & & & & & & & \\
\hline Quartz & & & & & & & & & & & & & & & & & & & & & & & & & & & & & & & & & & & & & & & \\
\hline Monocrystalline & & & & & & & & & & & & & & & & & & & & & & & & & & & & & & & & & & & & & & & \\
\hline Undulose & 13 & 4 & & 9 & & 5 & & & & & & & 5 & 4 & 3 & \begin{tabular}{l|l|}
3 & 7 \\
\end{tabular} & 4 & & & & 1 & 76 & & & & & & & & & & 4 & & 1 & & & & & \\
\hline Straight & & & & & & & & & & & & & 8 & & & & & & & 3 & & & & & & 9 & 9 & & & & & & & 2 & & & & & \\
\hline Polycrystalline & & & & & & & & & & & & & & & & & & & & & & & & & & & & & & & & & & & & & & & \\
\hline Equigranular & & & & & 4 & & & & & & & & & & & & & & & & 10 & & & & & & & & & & & & & 1 & & & & & \\
\hline Foliated & & & & & & & & & & & & & 38 & 7 & 7 & 5 & & & & & 2 & & & & & & & & & & & & & & & & & & \\
\hline Coarse & 58 & 6 & & & 24 & 9 & & & 115 & & & & 51 & 60 & & 42 & 5 & 48 & & 17 & 210 & 72 & & 12 & 5 & 4 & 4 & & & 3 & & & 10 & 4 & & & & & \\
\hline Feldspar Undifferentiated & 6 & 3 & & & & & & & 17 & & & & & & & & 2 & 3 & & 2 & & & & 3 & 3 & & & & & & & & & & & & & & \\
\hline Sedimentary Rock Fragment & & & & & & & & & & & & & & & & & & & & & & & & & & & & & & & & & & & & & & & \\
\hline Sandstone & & & & & & 6 & & & & & & & 8 & 9 & 9 & & & & & & & & & & & & & & & & & & & 10 & & & & & \\
\hline Metamorphic Rock Fras & & & & 1 & 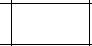 & & & & 2 & 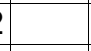 & & & & & & & & & & & & & & & & & & & & & & & & & & & & & \\
\hline Sedimentary Rock Frag & & & & 6 & & & & & 16 & & & & & & & & & & & & & & & & & & & & & & & & & & & & & & \\
\hline Undifferentiated Rock Fragment & & & & 5 & 5 & & & & 78 & & & & & & & & & & & & & & & & & & & & & & & & & & & & & & \\
\hline
\end{tabular}




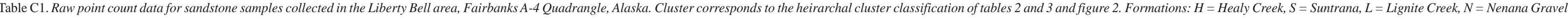
Geologist who point counted the sample: JEA = J.E. Athey, RLS = R.L. Smith. See Decker (1985) for descriptions of the types of lithics-continued.

\begin{tabular}{|c|c|c|c|c|c|c|c|c|c|c|c|c|c|c|c|c|c|c|c|c|c|c|c|c|c|c|c|c|c|c|c|c|c|c|c|c|c|}
\hline SAMPLE NUMBER & 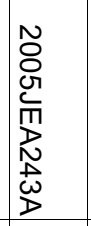 & 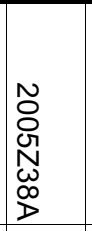 & 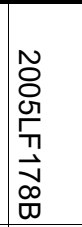 & 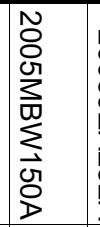 & 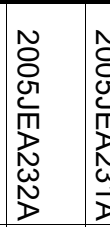 & 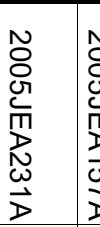 & 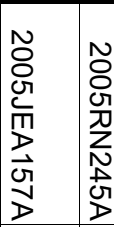 & 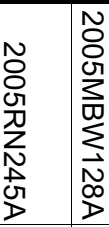 & 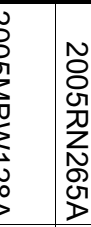 & 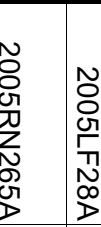 & 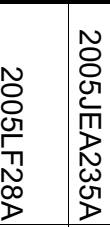 & 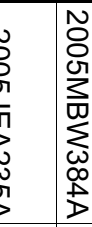 & 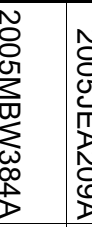 & 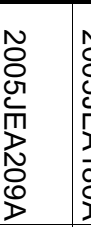 & 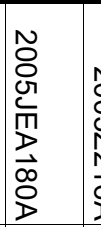 & 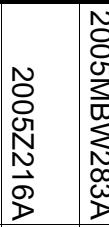 & 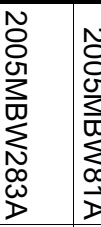 & 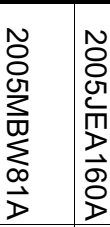 & 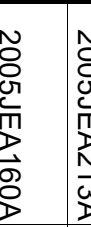 & 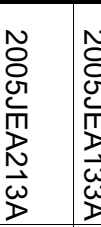 & 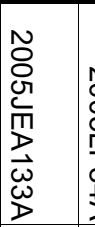 & 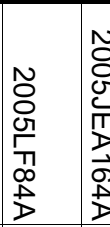 & 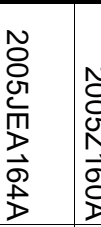 & 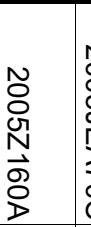 & 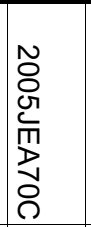 & 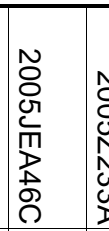 & 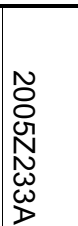 & 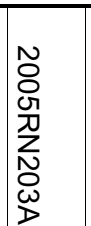 & 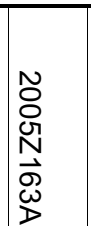 & 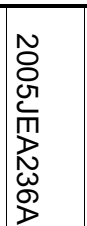 & 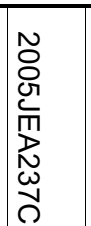 & 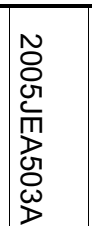 & 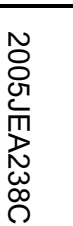 & 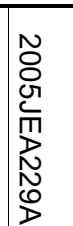 & 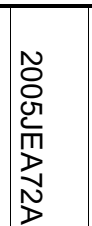 & 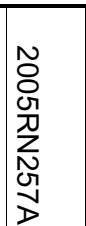 & 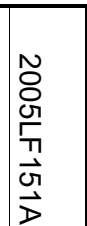 \\
\hline Feldspar & & & & 2 & & & & & 7 & & & & & & & & & & & & & & & & & & & & & & & & & & & & \\
\hline Quartz & & & & 5 & & & & & 66 & & & & & & & & & & & & 2 & & & & & & & & & & & & & & & & \\
\hline Matrix & & & & 4 & & & & & 21 & & & & & & & & & & & & & & & & & & & & & & & & & & & & \\
\hline Cement & & & & 30 & & & & & 10 & & & & & & & & & & & & & & & & & & & & & & & & & & & & \\
\hline Detrital Mineral & & & & 3 & & & & & 4 & & & & & & & & & & & & & & & & & & & & & & & & & & & & \\
\hline Siltstone & & 3 & & 14 & & & & & & & & & & & & & & & & & & & & & & & & & & & & & & & & & \\
\hline Foliated Chert & & 11 & & & 8 & & & & & & & & & & & 10 & & & & 15 & & & & 6 & & & & & & & & & & & & & \\
\hline Chert & & & & 3 & 21 & 33 & & & 96 & 2 & & & 12 & 86 & & 32 & & & & 11 & 12 & 82 & & 5 & & & & & & & & 3 & 7 & & & & \\
\hline Radiolarian & & & & 83 & & & & & 17 & & & & 131 & & & & & & & & 4 & 50 & & & & 62 & & & & & & & & & & & \\
\hline Argillite & & & & & & & & & 5 & & & & & & & & & & & & & & & & & & & & & & & 4 & & & & & \\
\hline Cherty Argillite & & & & & 2 & & & & 3 & & & & 7 & & & & & & & 1 & & 15 & & & & & & & & & & & & & & & \\
\hline Volcanic Rock Fragment & & & & & & & & & & & & & & & & & & & & & & & & & & & & & & & & & & & & & \\
\hline Microcrystalline & & & & & & & & & 31 & & & & 39 & & & & & & & 122 & 269 & & 63 & & & & & & & & & & & & & & \\
\hline Microgranular Felsic & & & & & & & & & 46 & & & & 78 & 17 & & & & 9 & & & 38 & 19 & & & & 10 & & & & & & & & & & & \\
\hline Porphyritic Felsic & & & & & & 5 & & & & & & & 42 & & & & & 75 & & & 233 & 25 & & & & 69 & & & & & & & & & & & \\
\hline Microlitic & & & & & & 11 & & & 2 & & & & & & & & & & & & & 33 & & & & & & & & & & & & & & & \\
\hline Porphyritic Intermediate & & & & & 2 & & & & & & & & & & & & & 10 & & & & & & & & 10 & & & & & & & & & & & \\
\hline Lathwork & & & & & 7 & & & & & & & & & & & & & & & & & & & & & & & & & & & & & & & & \\
\hline Altered & & & & & 6 & & & & & & & & & & & & & & & & & 25 & & & & & & & & & & & & & & & \\
\hline Metamorphic Rock Fragment & & & & & & & & & & & & & & & & & 4 & & & & & & & & & & & & & & & & & & & & 6 \\
\hline Unfoliated Metaclastic (Quartzite) & & & & 32 & 1 & & & & 2 & & & & 42 & & 302 & & 1 & 5 & & & 66 & & & & & 7 & & & & & & & 1 & & & & \\
\hline Quartz-Mica Phyllite & & 4 & & & & 3 & & & & & & & 5 & 2 & 155 & 3 & 3 & & & & 32 & & 4 & & & & & & & & & & & & & & \\
\hline Quartz-Mica Schist/Gneiss & 11 & 1 & & & & & & & & & & & & 9 & 160 & 14 & 2 & & & 3 & 76 & 99 & & 5 & & 367 & & & & & & 6 & & & & & \\
\hline Feldspar Undifferentiated & 23 & 4 & & 7 & 1 & & & & & & & & & & & & 1 & 5 & & & & & & & & & & & & & & & & & & & \\
\hline Mica & 55 & 4 & & 2 & & & & & & & & & & & & & 7 & 2 & & & & & & & & & & & & & & & & & & & \\
\hline Quartz & 74 & 18 & & 15 & 3 & 3 & & & & & & & & & & & 6 & 10 & & 4 & & & & & & & & & & & & & & & & & \\
\hline Plutonic Rock Fragment & & & & & & & & & & & & & & & & & & & & & & & & & & & & & & & & & & & & & \\
\hline Felsic & & & & & 2 & 69 & & & & & & & & & & & & & & & & 65 & & & & 20 & & & & & & & & & & & 10 \\
\hline Mafic & & & & 19 & 59 & & & & & & & & & & & & & & & & & & & & & & & & & & & & & & & & \\
\hline Intermediate & & & & 177 & 4 & 176 & & & & & & & & & & & & & & & 12 & 20 & & & & 10 & & & & & & & & & & & \\
\hline Rock Fragment Undifferentiated & & & & & & 1 & & & & & & & & & & & & & & & 1 & & & & & & & & & & & & & & & & \\
\hline Detrital Mineral & & & & & 1 & & & & & & & & & & & & & & & & & & & & & & & & & & & & & & & & \\
\hline
\end{tabular}




\begin{tabular}{|c|c|c|c|c|c|c|c|c|c|c|c|c|c|c|c|c|c|c|c|c|c|c|c|c|c|c|}
\hline SAMPLE NUMBER & 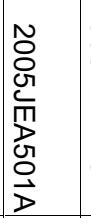 & 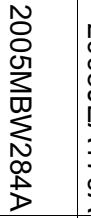 & 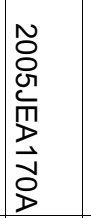 & 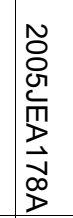 & 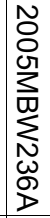 & 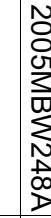 & & 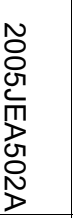 & 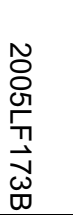 & 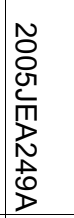 & 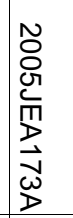 & 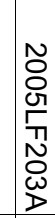 & 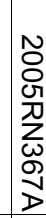 & & 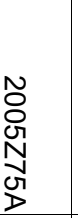 & 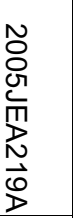 & 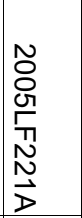 & 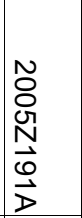 & 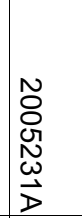 & 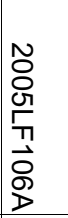 & 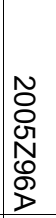 & 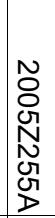 & 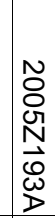 & 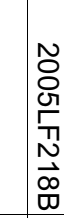 & & 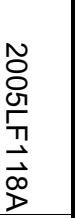 \\
\hline Cluster & L2 & L2 L L & L2 & L2 & $S$ & $S$ & & S & s & S & s & s & $\mathrm{H}$ & & $\mathrm{H} 2$ & $\mathrm{H} 2$ & $\mathrm{H} 2$ & $\mathrm{H} 2$ & H2 & $\mathrm{H} 2$ & $\mathrm{H} 2$ & $\mathrm{H} 2$ & $\mathrm{H}_{2}$ & $\mathrm{H}^{2}$ & & $\begin{array}{ll}\mathrm{H} 2 \\
\mathrm{H} 2\end{array}$ \\
\hline Geologist & RLS & RLS & JEA & JEA & & & EA & RLS & RLS & JEA & JEA & $\mathrm{RL}$ & & A. & JEA & JEA & JEA & JEA & JEA & JEA & $\mathrm{JE} / \mathrm{H}$ & $\mathrm{RL}$ & $\mathrm{JE}$ & & A. & JEA \\
\hline Total & 250 & 250 & 250 & 25 & & & 50 & 250 & 250 & 250 & 251 & & & 50 & 250 & 250 & 250 & 250 & 250 & 250 & 25 & 25 & 25 & & 0 & \\
\hline \multirow{2}{*}{\multicolumn{27}{|c|}{ Quartz }} \\
\hline Monocrystalline & & & & & & & & & & & & & & & & & & & & & & & & & & \\
\hline Undulose & 6 & 9 & 24 & $\begin{array}{ll}42 \\
2\end{array}$ & & 1 & 19 & 26 & 68 & 59 & $32+2+2$ & & & 48 & 59 & 86 & 42 & 30 & 40 & 37 & 6 & & & 0 & 29 & 38 \\
\hline Straight & 63 & 55 & 46 & \begin{tabular}{|c|c|}
5 & 6 \\
\end{tabular} & & & 32 & 101 & 86 & 48 & 62 & & & 86 & 76 & 28 & 72 & 88 & 54 & 89 & 4 & 13 & & 0 & 55 & \\
\hline Polycrystalline & & 7 & & & & & & & 4 & & & & 4 & & & & & & & & & & & & & \\
\hline Equigranular & 11 & 12 & 7 & 7 & 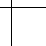 & 7 & 4 & 11 & & 14 & 7 & 7 & & 19 & 3 & 22 & 14 & 6 & 14 & 5 & 2 & & & 5 & 11 & \\
\hline Foliated & & 8 & 7 & & & 1 & & 11 & & 2 & 3 & 3 & & 2 & & 6 & 3 & 1 & 1 & 1 & & & & 3 & 1 & \\
\hline Coarse & & & 57 & $\begin{array}{ll}3 \\
3\end{array}$ & & & & 6 & & 27 & $4 c$ & & & 29 & 26 & 50 & 44 & 56 & 57 & 54 & 4 & & t. & 2 & 22 & \\
\hline Feldspar & 28 & 39 & 16 & \begin{tabular}{|l|l}
3 \\
3
\end{tabular} & & 5 & 13 & 23 & 39 & 13 & 16 & & & 6 & 11 & 13 & 10 & 5 & 13 & 8 & 1 & & & 0 & 8 & \\
\hline \multicolumn{27}{|l|}{ Alkali } \\
\hline Unaltered K-Spar & & & & & ? & 1 & 1 & 1 & & 26 & 1 & 1 & & & 7 & 10 & 1 & 1 & & 1 & & & & 3 & 2 & \\
\hline Perthitic/Tartan & 2 & 4 & 13 & & & & 4 & & & 5 & $1 \varepsilon$ & & & & 1 & 3 & 4 & 3 & 3 & & & & & 2 & & \\
\hline \multirow{2}{*}{\multicolumn{27}{|c|}{$\begin{array}{l}\text { Graphic } \\
\text { Altered }\end{array}$}} \\
\hline & & & & & & & & & & & & & & & 1 & & & & & & & & & & & \\
\hline Plagioclase & & & & & & & & & & & & & & & 1 & & & & & & & & & & & \\
\hline Myrmekitic & & & & & & & & 1 & & & & & & & & 1 & & & 1 & & & & & 1 & & \\
\hline \multirow{2}{*}{\multicolumn{27}{|c|}{ Unzoned }} \\
\hline Albite-Twin & 12 & 7 & 1 & 1 & & 1 & 11 & & & & & & & & & & & & & & & & & & & \\
\hline Carlsbad-Twins & 1 & 6 & & & & & & & 1 & & & & & & 1 & & & & & & & & & & & \\
\hline \multicolumn{27}{|l|}{ Chessboard } \\
\hline Untwinned & & & & & & & & & & & & & & 1 & & & 1 & & & & & & & & & \\
\hline \multirow{2}{*}{\multicolumn{27}{|c|}{$\begin{array}{l}\text { Zoned } \\
\text { A-Twin }\end{array}$}} \\
\hline & & & & & & & & & & & & & & & & & & & & & & & & & & \\
\hline \multicolumn{27}{|l|}{ Untwinned } \\
\hline Altered & & & & & & & & & & & & & & 1 & & & & & & & & & & & & \\
\hline Altered & & & 2 & 2 & & 1 & 1 & & & & 1 & 1 & & & 1 & & 1 & & & & & & & & & \\
\hline \multirow{2}{*}{\multicolumn{27}{|c|}{ Chert }} \\
\hline & & & & & & & & & & & & & & & & & & & & & & & & & & \\
\hline Common (Microcrystalline) & 14 & 13 & 10 & & & 6 & 3 & 13 & 20 & & $\mathrm{~s}$ & 9 & 1 & & 1 & & 10 & 9 & 13 & 12 & & & 5 & 6 & 10 & 15 \\
\hline Radiolarian & & & & & & & & & & & & & & & & & & & & & & & & & & \\
\hline Foliated (Metamorphic) & 7 & 4 & 2 & 2 & & 4 & & 5 & 1 & & 1 & 1 & & & 1 & & & 2 & & 7 & & & & 6 & 2 & \\
\hline \multicolumn{27}{|l|}{ Fibrous (Chalcedony) } \\
\hline Probable Cherty Grains & & & & & & 1 & 2 & & & & & 1 & & & & & & 1 & & & & & & 2 & & \\
\hline Cherty Argillite & 15 & 4 & 5 & 5 & ? & & 1 & & & & 4 & 4 & & & & & & 3 & 5 & 3 & & & & 6 & 7 & \\
\hline Argillite & & & & & & 3 & & & & & 3 & 3 & 5 & & & & 2 & 2 & 1 & & & & & 6 & 2 & \\
\hline Slate/Shale & & & 2 & 2 & & 1 & 5 & & & & 5 & 5 & 7 & & & & 2 & 2 & 2 & & & & & & 1 & \\
\hline Siltstone & & & & & & & 1 & & & 1 & 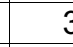 & 3 & & & & & & 1 & 1 & & & & & 2 & 4 & \\
\hline Sandstone & & & & & & 5 & & & & & & & & & & & & 3 & 2 & & & & & 1 & & \\
\hline Quartz & & 1 & 1 & & & & & 1 & & & & & & & & & & & & & & & & & & \\
\hline \multicolumn{27}{|l|}{ Plagioclase } \\
\hline \multirow{3}{*}{\multicolumn{27}{|c|}{$\begin{array}{l}\text { Feldspar } \\
\text { Garnet }\end{array}$}} \\
\hline & & & & & & & & & & & & & & & & & & & & & & & & & & \\
\hline Sedimentary Rock Fragment & & & & & & & & & & & & & & & & & & & & & & & & & & \\
\hline
\end{tabular}




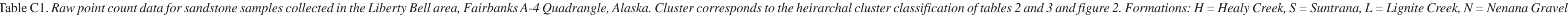
Geologist who point counted the sample: JEA = J.E. Athey, RLS = R.L. Smith. See Decker (1985) for descriptions of the types of lithics-continued.

\begin{tabular}{|c|c|c|c|c|c|c|c|c|c|c|c|c|c|c|c|c|c|c|c|c|c|c|c|}
\hline SAMPLE NUMBER & 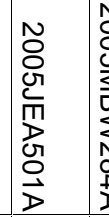 & 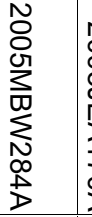 & 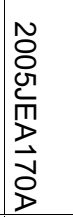 & 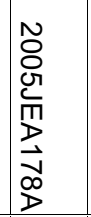 & 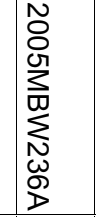 & 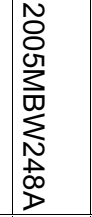 & 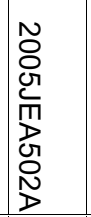 & 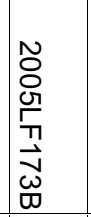 & 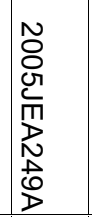 & 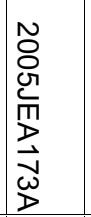 & 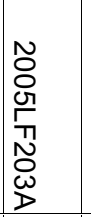 & 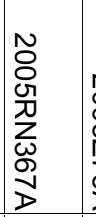 & 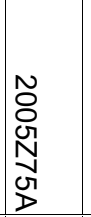 & 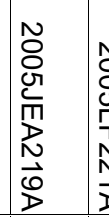 & 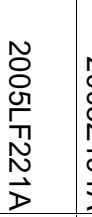 & 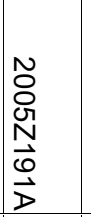 & 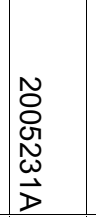 & 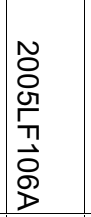 & 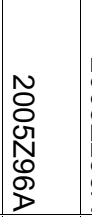 & 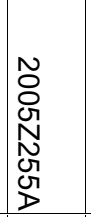 & 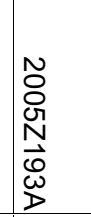 & 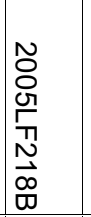 & 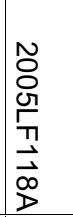 \\
\hline Volcanic Rock Fragment & & & & & & & & 3 & & & & & & & & & & & & & & & \\
\hline Metamorphic Rock Fragment & & & & & & & 2 & & & & & & & & & & & & & & & & \\
\hline Rock Fragment Undifferentiated & & & & & & & & & & & & & & & & & & & & & & & \\
\hline Detrital Mineral & & 1 & & & & & & & & & & & & & & & & & & & & & \\
\hline Matrix & & & & & & & & & & & & & & & & & & & & & & & \\
\hline Cement & & & & & & & 3 & 1 & & & & & & & & & & & & & & & \\
\hline Detrital Carbonate & & & & & & & & 1 & & & 2 & & & & & & & & & & & & \\
\hline Probable Sedimentary Rock Fragment & & 1 & & 2 & 2 & 7 & & & 1 & 2 & & & & & & 2 & 1 & 1 & & & & & 1 \\
\hline Volcanic Rock Fragment & & & & & & & & & & & & & & & & & & & & & & & \\
\hline Felsic & & & & 1 & 1 & & & & & 1 & & & & & & & & & & & & & \\
\hline Vitric/Cryptocrystalline & & & 6 & 1 & 1 & it & & 1 & & 3 & & & & & & & & & & & & 4 & 2 \\
\hline Microcrystalline & 29 & 14 & & 1 & 2 & 1 & 21 & & & & & & & & & & & & & & & & \\
\hline Microgranular & & & 1 & 5 & 1 & & 6 & & & & & & & & & 1 & & & & & & & \\
\hline Porphyritic & 31 & 29 & & 3 & 3 & & 6 & & & 1 & 4 & & & & & & & & & & & & \\
\hline Altered & & & & 1 & 1 & 3 & & & & & & & & & & & & & & & & & \\
\hline Intermediate & & & & & & & & & & & & & & & & & & & & & & & \\
\hline Microlitic & & & & 2 & 2 & & & & & & & & & & & & & & & & & & \\
\hline Porphyritic & & & & & & & & & & & & & & & & & & & & & & & \\
\hline Altered & & & 5 & ; & 2 & 2 & & & & & & & & & & & & & & & & & \\
\hline Mafic & & & & & & & & & & & & & & & & & & & & & & & \\
\hline Lathwork & 4 & 2 & & & & & 2 & 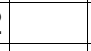 & & & & & & & & & & & & & & & \\
\hline Altered & & & & & & & & & & & & & & & & & & & & & & & \\
\hline Dissolved & & & & & & & & & & & & & & & & & & & & & & & \\
\hline Probable Volcanic Rock Fragment & 1 & & 1 & 2 & 2 & 1 & & & & 2 & & & & & & 1 & 2 & & & & & 2 & \\
\hline & & & & & & & & & & & & & & & & & & & & & & & \\
\hline Metamorphic Rock Fragment & 1 & & & & & & & & & & 1 & & & & & & & & & & & & \\
\hline Felsic & & & & & & & & & & & & & & & & & & & & & & & \\
\hline Unfoliated Metaclastic (Quartzite) & & 1 & & 2 & 2 & & & & & & & & & 2 & & 4 & & & 2 & 19 & 2 & & \\
\hline Quartz-Mica Phyllite & 3 & & 9 & 3 & 2 & 9 & 2 & 1 & 9 & 7 & & 2 & 8 & 7 & 5 & 5 & 3 & 7 & 10 & & 6 & 9 & 6 \\
\hline Quartz-Mica Schist/Gneiss & & 3 & 4 & 4 & 4 & & & & & 2 & 2 & & 2 & & & 1 & & 2 & 5 & & 1 & 6 & 9 \\
\hline Quartz & 1 & & 7 & 4 & 1 & & 1 & & 27 & 3 & 1 & 39 & 19 & 12 & 21 & 9 & 15 & 13 & 16 & 7 & 26 & 21 & 8 \\
\hline Mica & & 3 & 1 & 2 & 2 & & & & 6 & & & 9 & 10 & 2 & 5 & & 8 & 2 & 3 & 7 & 1 & 4 & \\
\hline Plagioclase & & & & & & & & & & & & & 1 & & 1 & & & & & & & & \\
\hline Alkali Feldspar & & & & & & & & & 2 & & & & 2 & 2 & & & 1 & & 3 & & & 1 & \\
\hline Feldspar Undifferentiated & & & 3 & & & & & & & 1 & & & 1 & & & & & & & & & & \\
\hline Mafic & & & & & & & & & & & & & & & & & & & & & & & \\
\hline Greenstone/Metavolcanic & 1 & & 2 & 2 & 2 & & & & & & & & 2 & & & & & & & & & & \\
\hline Green Phyllite & & & & & & & & & & & & & & & & & & & & & & & \\
\hline Greenschist/Amphibolite & & & & & & & & & & & & & & & & & & & & & & & \\
\hline Amphibole & & & & & & & & & & & & & & & & & & & & & & & \\
\hline Epidote Group & & & & & & & & & & & & & & & & & & & & 4 & & & \\
\hline Plagioclase & & & & & & & & & & & & & & & & & & & & & & & \\
\hline Mica & & & & & & & & & & & & & & & & & & & & & & & \\
\hline Hornfels & & & & & & & & & & & & & & & & & & & & & & & \\
\hline Probable Metamorphic Rock Fragment & 3 & 2 & 4 & 2 & 2 & 1 & & & & 2 & & & 1 & & & 1 & & 1 & 1 & & & 2 & \\
\hline Plutonic Rock Fragment & & & & & & & & & & & & & & & & & & & & & & & \\
\hline
\end{tabular}




\begin{tabular}{|c|c|c|c|c|c|c|c|c|c|c|c|c|c|c|c|c|c|c|c|c|c|c|c|}
\hline SAMPLE NUMBER & 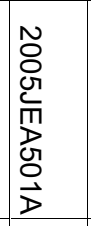 & 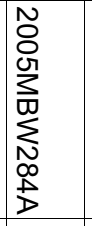 & 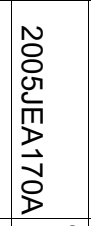 & 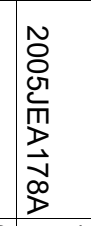 & 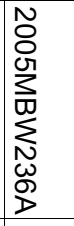 & 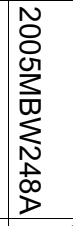 & 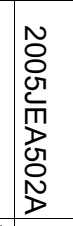 & 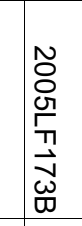 & 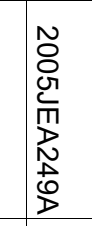 & 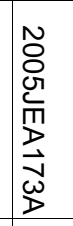 & 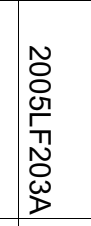 & 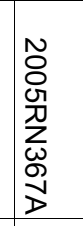 & $\begin{array}{l}\tilde{O} \\
\text { O } \\
N \\
\text { N } \\
>\end{array}$ & 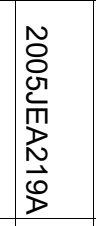 & 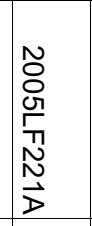 & 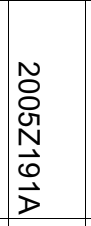 & 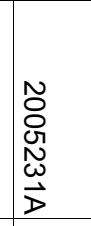 & 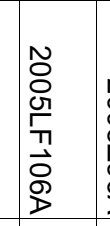 & $\begin{array}{l}N \\
0 \\
0 \\
0 \\
0 \\
D \\
\end{array}$ & $\begin{array}{l}N \\
0 \\
0 \\
N \\
\text { Wy } \\
\text { D }\end{array}$ & 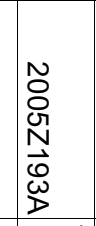 & 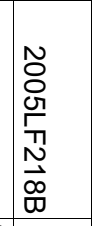 & 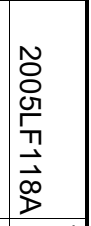 \\
\hline Felsic & & & 3 & 1 & & 1 & & & & & & & & & & & & & & & 1 & & \\
\hline Quartz & & & 3 & 2 & 2 & & & & & 2 & 2 & & 3 & & & & 1 & 1 & & 3 & 2 & 6 & \\
\hline K-Spar & & 1 & & 2 & 2 & & & & & 3 & 3 & & 2 & 1 & & & & 2 & & & & 1 & 1 \\
\hline Plagioclase & & 3 & 1 & 2 & 3 & & & & & ? & 1 & & & 2 & & & & & & & & & \\
\hline Biotite & & & & & & & & & & & & & & & & & & & & & & & \\
\hline Chlorite & & & & & & & & & & & & & & & & & & & & & & & \\
\hline Amphibole & & 3 & & & & & & & & & & & & & & & & & & & & & \\
\hline Altered & & & 2 & 2 & & & & & & & & & & & & & & & & & & & \\
\hline Intermediate & & & & & & & & & & & & & & & & & & & & & & & \\
\hline Plagioclase & & & & & & & & & & & & & & & & & 1 & & & & & & \\
\hline Amphibole & & & & & & & & & & & & & 2 & & & & & & & & & & \\
\hline Altered & & 2 & & & & & & & & & & & & & & & & & & & 1 & & \\
\hline Mafic & & & & & & & & & & & & & & & & & & & & & & & \\
\hline Plagioclase & & & & & & & & & & & & & & & & & & & & & & & \\
\hline Pyroxene & & 3 & & & & & & & & & & & & & & & & & & 1 & & & \\
\hline Altered & & & & & & & & & & & & & & & & & & & & & & & \\
\hline Probable Plutonic Rock Fragment & 1 & & & 1 & 1 & & & & & & & & & & & & & & & & & & \\
\hline Detrital Mineral & & & & & & & & & & & & & & & & & & & & & & & \\
\hline Biotite & 9 & 2 & & 6 & & & 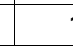 & $\begin{array}{lll}1 & 1\end{array}$ & & & & & 1 & & & 3 & 2 & & 4 & & 1 & & \\
\hline White Mica & 2 & 4 & 3 & 1 & 1 & 25 & & 2 & 8 & (2) & $1 \quad 18$ & 8 & 4 & 3 & \begin{tabular}{|l|l|}
3 & 11 \\
\end{tabular} & 5 & 8 & 3 & 4 & 2 & 4 & 9 & \\
\hline Chlorite & 1 & & 1 & 1 & & 2 & & 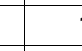 & 1 & & & & & & & 2 & 1 & & & & & & \\
\hline Mica, Undifferentiated & & & & & & & & & & & & & & & & & & & & & & & \\
\hline Pyroxene & 3 & & & & & & & & & & & & & & & & & & & & & & \\
\hline Amphibole & & 3 & 1 & 3 & & & & & & & & & 1 & & & 2 & & & & & & & \\
\hline Zircon & & & & & & & & & & & & & & & & & & & & & & & \\
\hline Tourmaline & & 1 & & & & & & & 1 & & & & & & & + & . & & & 2 & & & \\
\hline Apatite & & 2 & & & & & & & & & 10 & & & & & & & & & & & & \\
\hline Epidote & & & 1 & 1 & & 1 & & & & & & & & & & & & & & & & & \\
\hline Opaque Minerals & 1 & & & & & & & & & 2 & 2 & & & & & 1 & & & & & & & \\
\hline Undifferentiated Grain & & & 6 & 4 & 2 & c & & & & ( & 1 & 2 & 1 & & 5 & 1 & 6 & 2 & & & 1 & 1 & 2 \\
\hline Oversized Grain & & & & & & & & & & & & & & & & & & & & & & & \\
\hline Detrital Pebble & & & & & & & & & & & & & & & & & & & & & & & \\
\hline Quartz & & & & & & & & & & & & & & & & & & & & & & & \\
\hline Monocrystalline & & & & & & & & & & & & & & & & & & & & & & & \\
\hline Undulose & & & & & 14 & & & & 30 & & & & 57 & 100 & & & & & 5 & & & & \\
\hline Straight & & & & & 4 & & & & 39 & & & & 7 & & & & & & & & & & \\
\hline Polycrystalline & & & & & & & & & & & & & & & & & & & & & & & \\
\hline Equigranular & & 1 & & & & & & & & & & & & & & & & & & & & & \\
\hline Foliated & & & & & & & & & 5 & & & & & & & & & & & & & & \\
\hline Coarse & & & & & 33 & & & & 80 & & & & 116 & 87 & & 3 & & 7 & 7 & & 28 & 1 & \\
\hline Feldspar Undifferentiated & & & & & 2 & & & & 17 & & & & & 21 & & & & & & & 1 & & \\
\hline Sedimentary Rock Fragment & & 2 & & & & & & & & & & & & & & & & & & & & & \\
\hline Sandstone & & & & & 3 & & & & & & & & & & & & & & & & & & \\
\hline Metamorphic Rock FI & & & & & & & & & & & & & & & & & & & & & & & \\
\hline Sedimer & & & & & & & & & & & & & & & & & & & & & & & \\
\hline Undifferentiated Rock Fragment & & & & & & & & & & & & & & & & & & & & & & & \\
\hline
\end{tabular}




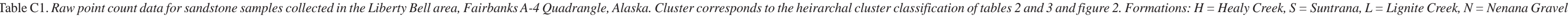
Geologist who point counted the sample: JEA = J.E. Athey, RLS = R.L. Smith. See Decker (1985) for descriptions of the types of lithics-continued.

\begin{tabular}{|c|c|c|c|c|c|c|c|c|c|c|c|c|c|c|c|c|c|c|c|c|c|c|c|c|c|c|}
\hline SAMPLE NUMBER & 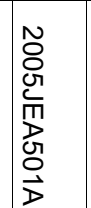 & 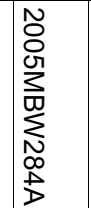 & 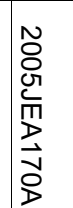 & 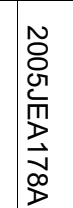 & 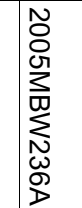 & 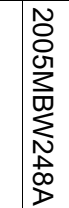 & 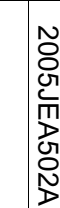 & & & 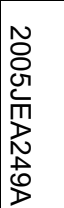 & 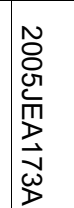 & 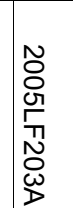 & 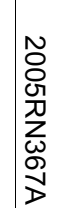 & $\begin{array}{l}N \\
\text { Ò } \\
\text { N } \\
\text { N } \\
>\end{array}$ & 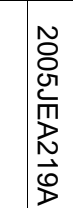 & $\begin{array}{l}\tilde{C} \\
0 \\
\\
\\
\\
\bar{I}\end{array}$ & 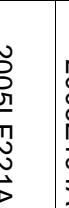 & 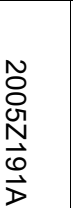 & 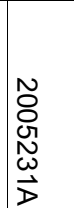 & 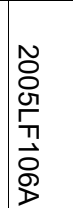 & $\begin{array}{l}\text { Oे } \\
\text { N } \\
0 \\
O \\
\end{array}$ & $\begin{array}{l}\text { Oू } \\
\text { N } \\
\text { Ny } \\
\text { N }\end{array}$ & 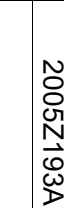 & & 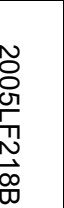 & 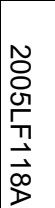 \\
\hline Feldspar & & & & & & & & & & & & & & & & & & & & & & & & & & \\
\hline Quartz & & & & & & & & & & & & & & & & & & & & & & & & & & \\
\hline Matrix & & & & & & & & & & & & & & & & & & & & & & & & & & \\
\hline Cement & & & & & & & & & & & & & & & & & & & & & & & & & & \\
\hline Detrital Mineral & & & & & & & & & & & & & & & & & & & & & & & & & & \\
\hline Siltstone & & & & & & & & & & & & & & & & & & & & & & & & & 6 & \\
\hline Foliated Chert & & & & & & & & & & & & & & 1 & 1 & & & & & & & & & & & \\
\hline Chert & & 1 & & & & & & & & & & & & & & 6 & & & & & & & & & & \\
\hline Radiolarian & & & & & & & & & & & & & & & & & & & & & & & & & & \\
\hline Argillite & & & & & & & & & & & & & & & & & & & & & & & & & & \\
\hline Cherty Argillite & & & & & & & & & & & & & & & & & & & & & & & & & & \\
\hline Volcanic Rock Fragment & & 3 & 3 & & & 4 & & & & & & & & & & & & & & & & & & & & \\
\hline Microcrystalline & & & & & & & & & & & & & & & & & & & & & & & & & & \\
\hline Microgranular Felsic & & 3 & 3 & & & & & & & & & & & & & & & & & & & & & & & \\
\hline Porphyritic Felsic & & & & & 1 & & & & & & & & & & & & & & & & & & & & & \\
\hline Microlitic & & & & & & & & & & & & & & & & & & & & & & & & & & \\
\hline Porphyritic Intermediate & & & & & & & & & & & & & & & & & & & & & & & & & & \\
\hline Lathwork & & & & & & & & & & & & & & & & & & & & & & & & & & \\
\hline Altered & & & & & & & & & & & & & & & & & & & & & & & & & & \\
\hline Metamorphic Rock Fragment & & & & & & & & & & & & & & & & & & & & & & & & & & \\
\hline Unfoliated Metaclastic (Quartzite) & & & & & & & & & & & & & & & & & & & & & & & & & & \\
\hline Quartz-Mica Phyllite & & & & & & & & & & & & & & & & 2 & & & & & & & & & & \\
\hline Quartz-Mica Schist/Gneiss & & & & & & & & & & & & & & & & 2 & & & & & & & & & 1 & \\
\hline Feldspar Undifferentiated & & & & & & & & & & & & & & & & 11 & & & & & & & & & & \\
\hline Mica & & & & & & & & & & & & & s & 1 & & 5 & & & & & & & & & & \\
\hline Quartz & & & & & & & & & & & & & & 4 & 4 & 29 & & & & & & & & 1 & & \\
\hline Plutonic Rock Fragment & & & & & & & & & & & & & & & & & & & & & & & & & & \\
\hline Felsic & & & & & & & & & & & & & & & 4 & 7 & & & & & & & & 4 & & \\
\hline Mafic & & & & & & & & & & & & & & & & & & & & & & & & & & \\
\hline Intermediate & & & & & & & & & & & & & & & & & & & & & & & & & & \\
\hline Rock Fragment Undifferentiated & & & & & & & & & & & & & & & & & & & & & & & & & & \\
\hline Detrital Mineral & & & & & & & & & & & & & & $1(1$ & 0 & & & & & & & & & & & \\
\hline
\end{tabular}




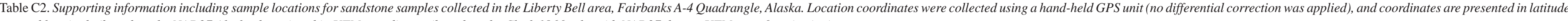
and longitude (based on the NAD27 Alaska datum) and in UTM coordinates (based on the Clark 1866 spheroid, NAD27 datum, UTM zone 6 projection).

\begin{tabular}{|c|c|c|c|c|c|c|c|c|}
\hline Sample Number & Latitude & Longitude & UTM Easting & UTM Northing & $\begin{array}{c}\text { Average Grain) } \\
\text { Size (mm }\end{array}$ & Range (mm) & Cement and matrix comments & Other comments \\
\hline 2005JEA133A & 64.093564 & -148.577705 & 423092 & 7108197 & 0.3 & $0.15-1.2$ & silty matrix & 5 large oversize grains \\
\hline 2005JEA157A & 64.003297 & -148.777907 & 413054 & 7098398 & 0.03 & $0.02-2.0$ & silty matrix with iron oxide and clay & 1 large oversize grain \\
\hline 2005JEA160A & 64.006314 & -148.761612 & 413860 & 7098712 & 0.4 & $0.2-0.75$ & & \\
\hline 2005JEA164A & 64.012388 & -148.732002 & 415326 & 7099349 & 0.25 & $0.05-0.75$ & & 2 oversize grains \\
\hline 2005JEA170A & 64.047766 & -148.733295 & 415370 & 7103292 & 0.5 & $0.02-1.65$ & & \\
\hline 2005JEA173A & 64.0442 & -148.728199 & 415608 & 7102888 & 0.375 & $0.15-1.6$ & sparse clay matrix & \\
\hline 2005JEA178A & 64.115652 & -148.514441 & 426234 & 7110583 & 0.2 & $0.1-0.3$ & & \\
\hline 2005JEA180A & 64.119489 & -148.522556 & 425849 & 7111020 & 0.25 & $0.02-1.75$ & discrete grains coated with iron oxide & 4 large oversize grains \\
\hline 2005JEA209A & 64.10764 & -148.827083 & 410983 & 7110090 & 0.1 & $0.02-2.0$ & silty matrix & 10 oversize grains \\
\hline 2005JEA213A & 64.105797 & -148.635565 & 420307 & 7109631 & 0.35 & $0.6-2.0$ & & 2 oversize grains; abundant chert \\
\hline 2005JEA219A & 64.104799 & -148.661061 & 419062 & 7109552 & 0.2 & $0.02-1.1$ & sparse silty matrix & 3 large oversize grains \\
\hline 2005JEA229A & 64.123932 & -148.670831 & 418642 & 7111696 & 0.25 & $0.02-1.5$ & iron oxide coating, clay matrix & 3 large oversize grains \\
\hline 2005JEA231A & 64.007224 & -148.970197 & 403666 & 7099112 & 0.25 & $0.02-2.0$ & silty matrix & \\
\hline 2005JEA232A & 64.01224 & -148.896199 & 407300 & 7099561 & 0.5 & $0.02-1.75$ & some grains have iron-oxide coating & \\
\hline 2005JEA235A & 64.016303 & -148.773537 & 413308 & 7099841 & 0.25 & $0.02-2.0$ & iron-oxide-coated grains, clayey and silty matrix & 2 oversize grains \\
\hline 2005JEA236A & 64.032161 & -148.726861 & 415637 & 7101545 & 0.15 & $0.02-0.85$ & & \\
\hline 2005JEA237C & 64.029431 & -148.7783 & 413116 & 7101310 & 0.15 & $0.02-0.5$ & & \\
\hline 2005JEA238C & 64.038074 & -148.761445 & 413966 & 7102250 & 0.45 & $0.1-1.5$ & & abundant oversize grains \\
\hline 2005JEA243A & 64.128475 & -148.630324 & 420627 & 7112151 & 0.5 & $0.35-1.5$ & iron-oxide-coated grains & 4 oversize grains \\
\hline 2005JEA249A & 64.074833 & -148.744287 & 414916 & 7106322 & 0.875 & $0.125-2.0$ & silica cement & \\
\hline 2005JEA46C & 64.075174 & -148.840417 & 410229 & 7106492 & 0.25 & $0.05-2.0$ & most small grains coated with iron oxide, silty clayey matrix & 8 large oversize grains \\
\hline 2005JEA501A & 63.920759 & -148.903578 & 406635 & 7089381 & 0.2 & $0.02-0.5$ & & \\
\hline 2005JEA502A & 63.925423 & -148.754555 & 413957 & 7089691 & 0.35 & $0.2-1.0$ & & \\
\hline 2005JEA503A & 63.925255 & -148.758052 & 413785 & 7089677 & 0.3 & $0.02-2.0$ & & \\
\hline 2005JEA70C & 64.063966 & -148.82371 & 411008 & 7105220 & 0.25 & $0.02-1.0$ & & 2 oversize grains \\
\hline 2005JEA72A & 64.066865 & -148.816642 & 411362 & 7105533 & 0.4 & $0.02-2.0$ & & 6 large oversize grains \\
\hline 2005LF106A & 64.040469 & -148.64595 & 419613 & 7102366 & 0.1 & $0.02-1.75$ & & \\
\hline 2005LF118A & 64.048635 & -148.664335 & 418739 & 7103299 & 0.2 & $0.03-1.0$ & & \\
\hline 2005LF151A & 64.091762 & -148.547404 & 424564 & 7107960 & 0.25 & $0.02-1.8$ & iron-oxide cement & 2 oversize quartz grains \\
\hline 2005LF173B & 64.090168 & -148.79346 & 412566 & 7108097 & 0.04 & $0.02-0.1$ & iron-oxide cement & \\
\hline 2005LF178B & 64.094737 & -148.799951 & 412264 & 7108615 & 0.02 & $<0.05$ & iron-oxide cement, fused & \\
\hline 2005LF203A & 64.1063 & -148.75876 & 414307 & 7109847 & 0.35 & $0.02-1.75$ & clayey matrix & \\
\hline 2005LF218B & 64.036905 & -148.544569 & 424554 & 7101845 & 0.25 & $0.20-1.75$ & & \\
\hline 2005LF221A & 64.040146 & -148.550481 & 424274 & 7102213 & 0.2 & $0.02-0.5$ & & \\
\hline 2005LF28A & 64.052315 & -148.791211 & 412557 & 7103877 & 0.25 & $0.2-0.0625$ & & abundant chert \\
\hline 2005LF84A & 64.087429 & -148.562322 & 423825 & 7107495 & 0.2 & $0.02-0.5$ & silty matrix & 6 large oversize grains \\
\hline 2005MBW128A & 64.072141 & -148.90997 & 406827 & 7106254 & 0.5 & $0.35-2.0$ & & \\
\hline 2005MBW150A & 64.095974 & -148.95199 & 404859 & 7108971 & 0.5 & $0.1-1$ & iron-oxide coatings around most grains & \\
\hline 2005MBW231A & 64.043246 & -148.583402 & 422675 & 7102598 & 0.125 & $0.02-1.0$ & clayey and silty matrix & \\
\hline 2005MBW236A & 64.038264 & -148.587604 & 422456 & 7102048 & 0.2 & $0.02-2.0$ & clayey and silty matrix & \\
\hline 2005MBW248A & 64.027821 & -148.651591 & 419301 & 7100964 & 0.02 & $<0.075$ & silty matrix, iron-oxide cement & \\
\hline 2005MBW283A & 64.102915 & -148.590221 & 422508 & 7109254 & 0.3 & $0.03-1.0$ & sparse clayey matrix & \\
\hline 2005MBW284A & 64.109604 & -148.575165 & 423260 & 7109981 & 0.25 & $0.1-2.0$ & some iron-oxide-coated grains and ferricreted clay & 4 large oversize grains \\
\hline 2005MBW384A & 64.051249 & -148.978693 & 403403 & 7104029 & 0.4 & $0.2-1.5$ & iron-oxide cement between sparse grains & abundant oversize grains \\
\hline 2005MBW81A & 64.057201 & -148.888229 & 407838 & 7104558 & 0.25 & $0.1-0.75$ & clayey silty matrix & \\
\hline 2005RN203A & 64.048644 & -148.837192 & 410301 & 7103532 & 0.25 & $0.02-0.065$ & & \\
\hline 2005RN245A & 64.044883 & -148.995838 & 402544 & 7103346 & 0.2 & $0.05-1.0$ & & \\
\hline 2005RN257A & 64.022737 & -148.913039 & 406512 & 7100755 & 0.2 & $0.15-1.5$ & & \\
\hline
\end{tabular}




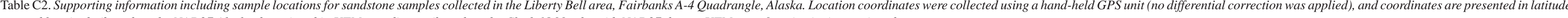
and longitude (based on the NAD27 Alaska datum) and in UTM coordinates (based on the Clark 1866 spheroid, NAD27 datum, UTM zone 6 projection)-continued.

\begin{tabular}{|c|c|c|c|c|c|c|c|c|}
\hline Sample Number & Latitude & Longitude & UTM Easting & UTM Northing & $\begin{array}{l}\text { Average Grain) } \\
\text { Size (mm }\end{array}$ & Range $(\mathrm{mm})$ & Cement and matrix comments & Other comments \\
\hline 2005RN265A & 64.040954 & -148.883279 & 408026 & 7102741 & 0.5 & $0.02-1.0$ & & \\
\hline 2005RN367A & 64.008057 & -148.604236 & 421559 & 7098703 & 0.25 & $0.01-0.55$ & abundant clayey matrix & \\
\hline 2005Z160A & 64.018709 & -148.67524 & 418119 & 7099979 & 0.45 & $0.02-2.0$ & & bimodal, very fine- and medium-grained \\
\hline 2005Z163A & 64.011075 & -148.677953 & 417964 & 7099132 & 0.25 & $0.02-1.0$ & clayey matrix & \\
\hline 2005Z191A & 64.027039 & -148.696065 & 417126 & 7100934 & 0.15 & $0.02-1.625$ & clayey matrix & \\
\hline 2005Z193A & 64.028761 & -148.683048 & 417767 & 7101109 & 0.175 & $0.02-2$ & sparse clayey, silty matrix & \\
\hline $2005 Z 216 A$ & 64.082108 & -148.982238 & 403337 & 7107472 & 0.4 & $0.02-2.0$ & clayey matrix & \\
\hline 2005Z233A & 64.009175 & -148.673769 & 418163 & 7098915 & 0.3 & $0.15-0.5$ & iron-oxide cement & \\
\hline $2005 Z 255 A$ & 64.074286 & -148.773144 & 414229 & 7106465 & 0.3 & $0.125-2.0$ & clay matrix & \\
\hline $2005 Z 38 A$ & 64.124866 & -148.743541 & 415105 & 7111895 & 0.625 & $0.075-1.625$ & & \\
\hline 2005Z75A & 64.084901 & -148.745266 & 414899 & 7107445 & 0.3 & $0.02-1.5$ & silty matrix & 4 large oversize grains \\
\hline 2005Z96A & 64.080278 & -148.688271 & 417664 & 7106855 & 0.2 & $0.02-1.75$ & clayey matrix & \\
\hline
\end{tabular}




\section{Appendix D}

\section{Clay compositions of Tertiary samples}

Clay mineralogy was determined for 65 fine-grained, poorly consolidated, sedimentary rock samples (table D1). Compacted samples were gently broken apart with a rubber-topped pestle and ceramic mortar. A clay fraction with low silt content was prepared by dry sieving and retaining the -325 or -400 mesh fraction. After adding acetone to a representative portion, the suspended solids were transferred to a glass slide and allowed to dry. Diffractometer traces were obtained by scanning $5-13^{\circ}$ at $0.5^{\circ}$ per minute using Ni-filtered Cu radiation on a Rigaku XRD. Relative heights of the $12.5^{\circ}$ (kaolinite and/or chlorite), 8.5-9 (illite/muscovite), and 6.2-6.9 (montmorillonite and/or chlorite) peaks were then recorded. Samples were also tested with Benzidine for the presence of montmorillonite; positive if the sample turned bright blue. If the sample turned greenish blue, montmorillonite was considered present if it also displayed a broad peak in the 6.2-6.9 range. (Chlorite displays a sharp peak in this region.) Nine of 15 samples with questionable Benzidine reactions had such peaks. Chlorite was unambiguously identified if the sample displayed both $6.2-6.9^{\circ}$ and $12.5^{\circ}$ peaks and also failed the Benzidine test. Kaolinite was unambiguously identified if the sample displayed a $12.5^{\circ}$ peak but no $6.2-6.9^{\circ}$ peak. Samples with an additional peak in the vicinity of $10^{\circ}$ were noted as possibly containing a zeolite. 
This page has intentionally been left blank. 
Table D1. Qualitative clay compositions of Tertiary samples from the Liberty Bell area, Fairbanks, A-4 Quadrangle, Alaska determined by X-ray diffraction and benzidine application. Location coordinates were collected using a hand-held GPS unit (no differential correction was applied), and coordinates are presented in latitude and longitude (based on the NAD27 Alaska datum) and in UTM coordinates (based on the Clark 1866 spheroid, NAD27 datum, UTM zone 6 projection). Key: xxxxx = very large peak, xxxx = large peak, $x x x=$ moderate peak, $x x=$ small peak, $x=$ very small peak, and blank $=$ no peak .

\begin{tabular}{|c|c|c|c|c|c|c|c|}
\hline Sample Number & Latitude & Longitude & $\begin{array}{c}\text { UTM } \\
\text { Easting }\end{array}$ & $\begin{array}{c}\text { UTM } \\
\text { Northing }\end{array}$ & Kaolinite & Montorillonite & Other minerals \\
\hline 2005JEA133A & 64.093564 & -148.577705 & 423092 & 7108197 & $x$ & $x$ & \\
\hline 2005JEA155A & 63.997823 & -148.795226 & 412190 & 7097812 & $x x$ & $x$ & \\
\hline 2005JEA155B & 63.997823 & -148.795226 & 412190 & 7097812 & $x$ & $x x x$ & \\
\hline 2005JEA157A & 64.003297 & -148.777907 & 413054 & 7098398 & $x x x$ & $x x$ & \\
\hline 2005JEA160A & 64.006314 & -148.761612 & 413860 & 7098712 & $x$ & & Possible zeolite \\
\hline 2005JEA164A & 64.012388 & -148.732002 & 415326 & 7099349 & $x$ & $x$ & \\
\hline 2005JEA171A & 64.045254 & -148.730149 & 415516 & 7103008 & $x x$ & $x$ & \\
\hline 2005JEA173A & 64.0442 & -148.728199 & 415608 & 7102888 & $x X x x$ & $x X X$ & Chlorite? \\
\hline 2005JEA209A & 64.10764 & -148.827083 & 410983 & 7110090 & $x x x$ & & \\
\hline 2005JEA213A & 64.105797 & -148.635565 & 420307 & 7109631 & $x$ & $x$ & \\
\hline 2005JEA213A (duplicate) & 64.105797 & -148.635565 & 420307 & 7109631 & $x$ & $x X X$ & Chlorite? \\
\hline 2005JEA219A & 64.10479 & -148.661061 & 419062 & 7109552 & $x x x x$ & & \\
\hline 2005JEA229A & 64.123932 & -148.670831 & 418642 & 7111696 & & $x x x$ & Chlorite? \\
\hline 2005JEA232A & 64.01224 & -148.896199 & 407300 & 7099561 & $x$ & $x$ & \\
\hline 2005JEA234A & 64.00725 & -148.790779 & 412437 & 7098856 & $x$ & $x$ & \\
\hline 2005JEA237C & 64.029431 & -148.7783 & 413116 & 7101310 & $x x$ & & \\
\hline 2005JEA238C & 64.038074 & -148.761445 & 413966 & 7102250 & $x x$ & $x$ & Possible zeolite \\
\hline 2005JEA266A & 64.097881 & -148.701281 & 417082 & 7108833 & $x x x$ & & \\
\hline 2005JEA502A & 63.925423 & -148.754555 & 413957 & 7089691 & $x x x$ & $x$ & Chlorite? \\
\hline 2005JEA503A & 63.925255 & -148.758052 & 413785 & 7089677 & $x x x$ & $x$ & \\
\hline 2005JEA58A & 64.04759 & -148.882396 & 408091 & 7103479 & $x$ & $x$ & \\
\hline 2005JEA59A & 64.050125 & -148.884226 & 408010 & 7103764 & $x$ & & \\
\hline 2005JEA64A & 64.062592 & -148.850757 & 409684 & 7105105 & $x x x$ & $x x x x$ & \\
\hline 2005JEA70C & 64.063966 & -148.82371 & 411008 & 7105220 & $x$ & & \\
\hline 2005JEA72A & 64.066865 & -148.816642 & 411362 & 7105533 & $x$ & & \\
\hline 2005LF103A & 64.042218 & -148.641363 & 419842 & 7102555 & $x x x$ & $x$ & \\
\hline 2005LF106A & 64.040469 & -148.64595 & 419613 & 7102366 & $x X X X$ & & \\
\hline 2005LF107A & 64.039087 & -148.648346 & 419492 & 7102215 & $x x x x$ & $x$ & Chlorite? \\
\hline 2005LF108E & 64.03838 & -148.649758 & 419421 & 7102138 & $X X X X X$ & & \\
\hline 2005LF110A & 64.037474 & -148.654435 & 419190 & 7102043 & $x X X X$ & $x$ & \\
\hline 2005LF111A & 64.03683 & -148.656526 & 419086 & 7101974 & $x X X X$ & $x$ & \\
\hline 2005LF118A & 64.048635 & -148.664335 & 418739 & 7103299 & $x X X x$ & $x x x$ & \\
\hline 2005LF119A & 64.046805 & -148.665783 & 418663 & 7103097 & $X X X X X$ & $x x$ & \\
\hline
\end{tabular}


Table D1. Qualitative clay compositions of Tertiary samples from the Liberty Bell area, Fairbanks, A-4 Quadrangle, Alaska determined by X-ray diffraction and benzidine application. Location coordinates were collected using a hand-held GPS unit (no differential correction was applied), and coordinates are presented in latitude and longitude (based on the NAD27 Alaska datum) and in UTM coordinates (based on the Clark 1866 spheroid, NAD27 datum, UTM zone 6 projection). Key: xxxxx = very large peak, xxxx = large peak, $x x x=$ moderate peak, $x x=$ small peak, $x=$ very small peak, and blank = no peak-continued.

\begin{tabular}{|c|c|c|c|c|c|c|c|}
\hline Sample Number & Latitude & Longitude & $\begin{array}{c}\text { UTM } \\
\text { Easting }\end{array}$ & $\begin{array}{c}\text { UTM } \\
\text { Northing }\end{array}$ & Kaolinite & Montorillonite & Other minerals \\
\hline 2005LF120A & 64.046054 & -148.66709 & 418597 & 7103015 & $x x x x$ & $x x$ & \\
\hline 2005LF186A & 64.086335 & -148.756658 & 414348 & 7107620 & $x x x x$ & & \\
\hline 2005LF186A (duplicate) & 64.086335 & -148.756658 & 414348 & 7107620 & $x x x x$ & & \\
\hline 2005LF203A & 64.1063 & -148.75876 & 414307 & 7109847 & $x x x x x$ & & \\
\hline 2005LF217B & 64.036322 & -148.543758 & 424592 & 7101779 & $x x x x x$ & & \\
\hline 2005LF218A & 64.036905 & -148.544569 & 424554 & 7101845 & $x X X X X$ & $x$ & \\
\hline 2005LF218B & 64.036905 & -148.544569 & 424554 & 7101845 & $x x x x x$ & $x x$ & Chlorite? \\
\hline 2005LF221A & 64.040146 & -148.550481 & 424274 & 7102213 & $x x x x$ & & Chlorite? \\
\hline 2005LF27A & 64.051843 & -148.798926 & 412179 & 7103835 & & & Chlorite? \\
\hline 2005LF31B & 64.050347 & -148.762752 & 413940 & 7103619 & $x x$ & $x$ & Possible Zeolite \\
\hline 2005LF84A & 64.087429 & -148.562322 & 423825 & 7107495 & & & All chlorite and mica \\
\hline 2005LF86A & 64.089843 & -148.554005 & 424237 & 7107754 & $x x x$ & & Possible Zeolite \\
\hline 2005MBW128A & 64.072141 & -148.90997 & 406827 & 7106254 & $x$ & $x x$ & \\
\hline 2005MBW150A & 64.095974 & -148.95199 & 404859 & 7108971 & $x$ & $x x x$ & \\
\hline 2005MBW231A & 64.043246 & -148.583402 & 422675 & 7102598 & $x x x x$ & $x$ & \\
\hline 2005MBW236A & 64.038264 & -148.587604 & 422456 & 7102048 & $x x x$ & $x$ & \\
\hline 2005MBW283A & 64.102915 & -148.590221 & 422508 & 7109254 & $x x$ & & \\
\hline 2005MBW81A & 64.057201 & -148.888229 & 407838 & 7104558 & $x$ & & \\
\hline 2005RN203A & 64.048644 & -148.837192 & 410301 & 7103532 & $x x$ & $x$ & \\
\hline 2005RN245A & 64.044883 & -148.995838 & 402544 & 7103346 & $x$ & & \\
\hline 2005RN251A & 64.03335 & -148.981848 & 403187 & 7102040 & $x$ & $x$ & \\
\hline 2005RN257A & 64.022737 & -148.913039 & 406512 & 7100755 & $x x$ & $x x x$ & \\
\hline 2005RN265A & 64.040954 & -148.883279 & 408026 & 7102741 & $x x$ & & \\
\hline 2005RN367A & 64.008057 & -148.604236 & 421559 & 7098703 & $x x x x x$ & $x x x x$ & \\
\hline 2005RN371A & 64.019655 & -148.627514 & 420454 & 7100024 & $x x x$ & & Chlorite? \\
\hline 2005RN372A & 64.020129 & -148.636505 & 420016 & 7100088 & $x x x$ & & Chlorite? \\
\hline 2005RN373A & 64.022734 & -148.633915 & 420150 & 7100375 & $x x x x$ & $x x$ & \\
\hline 2005RN374A & 64.022589 & -148.628401 & 420419 & 7100352 & $x x x$ & & Chlorite? \\
\hline 2005RN398A & 64.017414 & -148.639211 & 419876 & 7099789 & $X X X X$ & & \\
\hline 2005Z191A & 64.027039 & -148.696065 & 417126 & 7100934 & $x x x x$ & $x x$ & Chlorite? \\
\hline 2005Z193A & 64.028761 & -148.683048 & 417767 & 7101109 & $\mathrm{x}$ & & Mostly chlorite \\
\hline $2005 Z 255 A$ & 64.075946 & -148.758444 & 413507 & 7106300 & $x x x x x$ & & \\
\hline 2005Z38A & 64.124866 & -148.743541 & 415105 & 7111895 & $x x x$ & & \\
\hline 2005Z75A & 64.084901 & -148.745266 & 414899 & 7107445 & $x x x x$ & & \\
\hline
\end{tabular}




\section{Appendix E \\ Palynology}

Fifteen fine-grained sedimentary rock and coal samples were selected for palynology (table E1). Samples were processed by Russ Harms of Global Geolab Ltd. and analyzed by R.L. Ravn of the IRF Group, Inc. See table 4 for assigned Tertiary units and indicated environmental conditions during deposition. 
This page has intentionally been left blank. 
Table E1. Raw pollen count data. Location coordinates were collected using a hand-held GPS unit (no differential correction was applied), and coordinates are presented in latitude and longitude (based on the NAD 27 Alaska datum) and in UTM coordinates (based on the Clark 1866 spheroid, NAD 27 datum, UTM zone 6 projection). Note: $n=$ pollen grain was noted in the sample but not included in the total counted grains of the sample.

\begin{tabular}{|c|c|c|c|c|c|c|c|c|c|c|c|}
\hline & & & & & & Climate & warm & warm & warm & warm & warm \\
\hline & & & & & & Moisture & & & & & \\
\hline & & & & & & Common Name & $\begin{array}{l}\text { basswood } \\
\text { or linden }\end{array}$ & $\begin{array}{l}\text { basswood } \\
\text { or linden }\end{array}$ & cyprus & elm & fern \\
\hline & & & & & & Age & Miocene & Miocene & Miocene & Miocene & Miocene \\
\hline $\begin{array}{l}\frac{\sigma}{0} \\
\stackrel{0}{0} \\
0 \\
0 \\
\frac{0}{0} \\
\sum\end{array}$ & 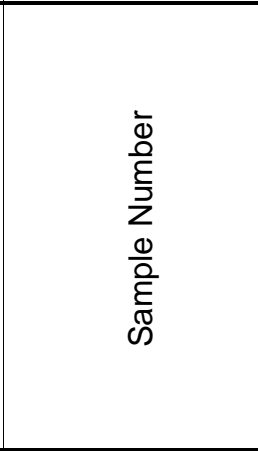 & 竞 & 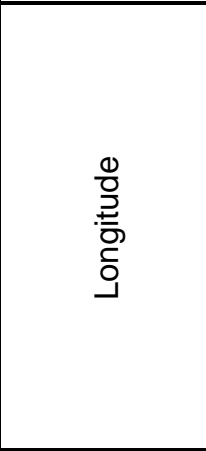 & 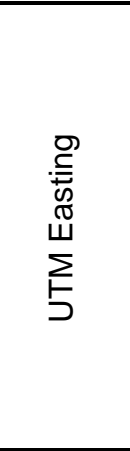 & 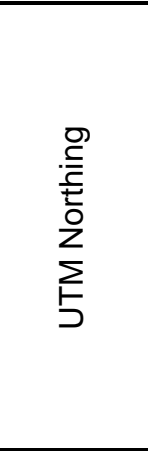 & 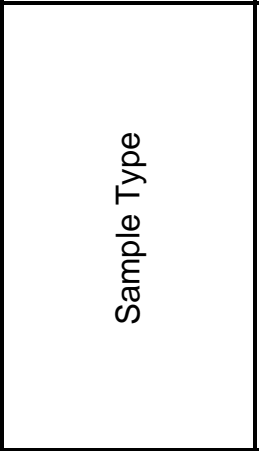 & 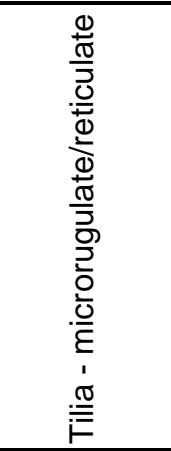 & 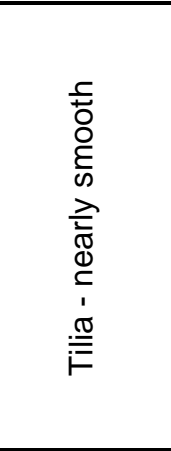 & 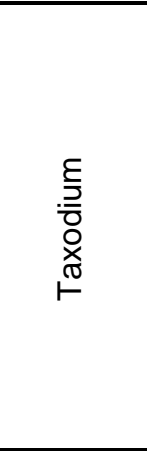 & 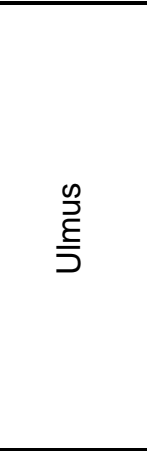 & 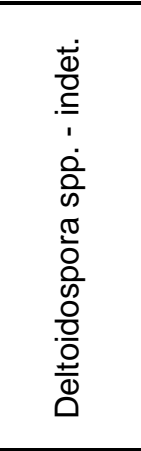 \\
\hline $\mathrm{P} 1$ & 2005JEA160C & 64.006314 & -148.761612 & 413860 & 7098712 & shale & & $n$ & $n$ & 4 & \\
\hline $\mathrm{P} 2$ & 2005JEA237B & 64.029431 & -148.7783 & 413116 & 7101310 & siltstone & 1 & 6 & & 16 & 4 \\
\hline P3 & 2005MBW415A & 64.046366 & -148.729501 & 415551 & 7103131 & coal & & 1 & & 3 & 1 \\
\hline $\mathrm{P} 4$ & $2005 Z 235 A$ & 64.003595 & -148.725669 & 415609 & 7098361 & coal & & & & & \\
\hline P5 & 2005Z165B & 64.013015 & -148.684044 & 417672 & 7099356 & silty sandstone & & 1 & & $\mathrm{n}$ & 3 \\
\hline P6 & 2005Z171B & 64.021726 & -148.697523 & 417039 & 7100344 & siltstone & & 2 & & & 5 \\
\hline P7 & 2005LF124A & 64.035824 & -148.678539 & 418008 & 7101890 & coal & & & & 1 & 5 \\
\hline P8 & 2005Z47B & 64.102325 & -148.734638 & 415470 & 7109372 & siltstone & & & $\mathrm{n}$ & $\mathrm{n}$ & 2 \\
\hline P9 & 2005MBW232A & 64.042121 & -148.582048 & 422738 & 7102471 & coal & & & & 1 & \\
\hline P10 & 2005MBW144A & 64.086613 & -148.939087 & 405456 & 7107909 & coal & & 1 & 1 & 1 & \\
\hline P11 & 2005JEA210C & 64.106886 & -148.828512 & 410911 & 7110008 & siltstone & & $\mathrm{n}$ & 3 & 10 & 1 \\
\hline P12 & 2005LF105A & 64.040906 & -148.639873 & 419911 & 7102407 & coal & & & & 12 & 2 \\
\hline P13 & 2005Z36C & 64.125307 & -148.752381 & 414676 & 7111956 & siltstone & & $\mathrm{n}$ & 2 & 4 & 16 \\
\hline P14 & 2005LF217D & 64.036322 & -148.543758 & 424592 & 7101779 & coal & & & & & 1 \\
\hline P15 & 2005Z229A & 64.00186 & -148.67057 & 418298 & 7098096 & coal & & & & & \\
\hline
\end{tabular}


Table E1. Raw pollen count data. Location coordinates were collected using a hand-held GPS unit (no differential correction was applied), and coordinates are presented in latitude and longitude (based on the NAD 27 Alaska datum) and in UTM coordinates (based on the Clark 1866 spheroid, NAD 27 datum, UTM zone 6 projection). Note: $n=$ pollen grain was noted in the sample but not included in the total counted grains of the sample-continued.

\begin{tabular}{|c|c|c|c|c|c|c|c|c|c|c|c|c|c|}
\hline & & warm & warm & warm & warm & warm & warm & warm & warm & warm & warm & $\mathrm{cool}$ & $\mathrm{cool}$ \\
\hline & & hickory & hickory & holly & larch & oak & oak & sequoia & $\begin{array}{l}\text { tropical } \\
\text { fern }\end{array}$ & $\begin{array}{c}\text { tulip tree } \\
\text { or yellow } \\
\text { poplar }\end{array}$ & walnut & alder & alder \\
\hline & & Miocene & Miocene & Miocene & Miocene & Miocene & Miocene & Miocene & Miocene & Miocene & Miocene & Miocene & Miocene \\
\hline 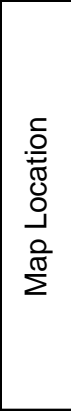 & 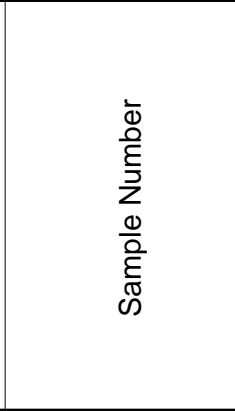 & 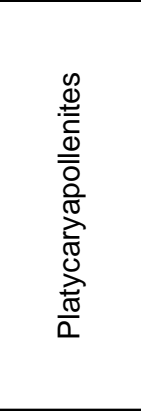 & 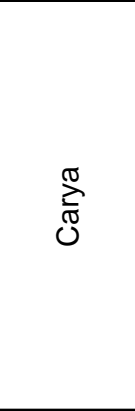 & $\stackrel{\text { Ð }}{=}$ & 肴 & $\frac{\mathscr{0}}{0}$ & 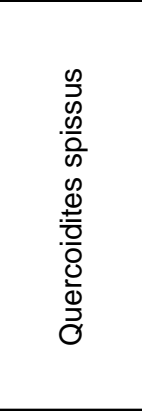 & $\begin{array}{l}\frac{\pi}{0} \\
\frac{0}{0} \\
0 \\
0\end{array}$ & $\begin{array}{l}\frac{\pi}{O} \\
\frac{c}{5} \\
\frac{E}{n} \\
0\end{array}$ & 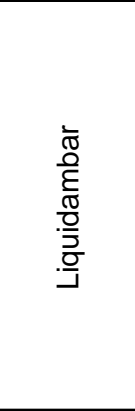 & $\frac{\substack{c \\
\frac{\pi}{0} \\
\frac{5}{3}}}{n}$ & $\frac{\text { n }}{2}$ & 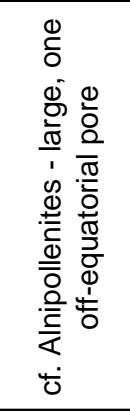 \\
\hline $\mathrm{P} 1$ & 2005JEA160C & 1 & & & & 1 & & $\mathrm{n}$ & $\mathrm{n}$ & & $\mathrm{n}$ & 2 & \\
\hline $\mathrm{P} 2$ & 2005JEA237B & $\mathrm{n}$ & & & & 3 & & & 1 & & 1 & 31 & \\
\hline P3 & 2005MBW415A & 2 & & 3 & & & & & 4 & & & 34 & \\
\hline P4 & 2005Z235A & & & & & & & & & & & 16 & \\
\hline P5 & 2005Z165B & & & & & & & & 2 & & & 57 & \\
\hline P6 & 2005Z171B & 7 & & & & & & & 1 & & 3 & 19 & $\mathrm{n}$ \\
\hline P7 & 2005LF124A & & & 3 & & 1 & & & 1 & & & 17 & \\
\hline P8 & 2005Z47B & 1 & 2 & $\mathrm{n}$ & 1 & & & & 1 & & & 5 & \\
\hline P9 & 2005MBW232A & & & & & & & & $\mathrm{n}$ & & & 13 & \\
\hline P10 & 2005MBW144A & 1 & & 3 & & & & & $\mathrm{n}$ & & & 64 & \\
\hline P11 & 2005JEA210C & 1 & 9 & & 2 & 1 & & & 9 & & 3 & 12 & \\
\hline P12 & 2005LF105A & & & & & & & & 39 & & & 12 & \\
\hline P13 & $2005 Z 36 C$ & $\mathrm{n}$ & 21 & $\mathrm{n}$ & & 1 & 1 & & 51 & 4 & & 35 & \\
\hline P14 & 2005LF217D & & & & & & & & & & & & \\
\hline P15 & 2005Z229A & & & & & & & & & & & & \\
\hline
\end{tabular}


Table E1. Raw pollen count data. Location coordinates were collected using a hand-held GPS unit (no differential correction was applied), and coordinates are presented in latitude and longitude (based on the NAD 27 Alaska datum) and in UTM coordinates (based on the Clark 1866 spheroid, NAD 27 datum, UTM zone 6 projection). Note: $n=$ pollen grain was noted in the sample but not included in the total counted grains of the sample-continued.

\begin{tabular}{|c|c|c|c|c|c|c|c|c|c|c|c|c|c|}
\hline & & $\mathrm{cool}$ & $\mathrm{cool}$ & $\mathrm{cool}$ & $\mathrm{cool}$ & $\mathrm{cool}$ & $\mathrm{cool}$ & $?$ & $?$ & $?$ & $?$ & $?$ & $?$ \\
\hline & & & & & & & & wet & wet & wet & wet & & \\
\hline & & birch & fir & juniper & pine & similar to birch & spruce & algal & algal & algal & algal & $\begin{array}{l}\text { angio- } \\
\text { sperm }\end{array}$ & $\begin{array}{l}\text { angio- } \\
\text { sperm }\end{array}$ \\
\hline & & Miocene & Miocene & Miocene & Miocene & Miocene & Miocene & Miocene & Miocene & Miocene & Miocene & Miocene & Miocene \\
\hline 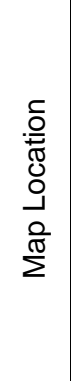 & 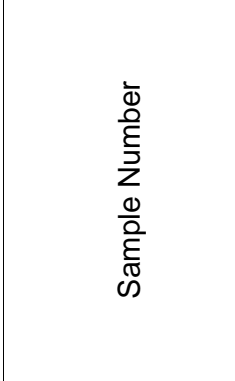 & $\begin{array}{l}\frac{\pi}{2} \\
\frac{D}{0} \\
\infty\end{array}$ & $\frac{\mathscr{d}}{\frac{0}{\alpha}}$ & 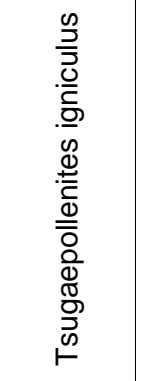 & $\stackrel{\mathscr{n}}{\stackrel{D}{=}}$ & 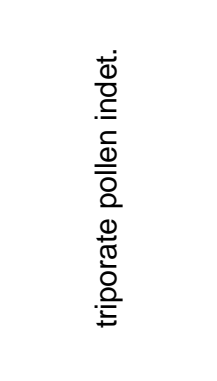 & $\begin{array}{l}\frac{\pi}{\mathbb{U}} \\
\stackrel{0}{\alpha}\end{array}$ & 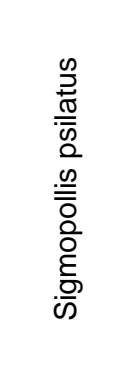 & 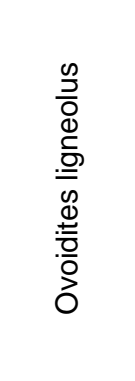 & 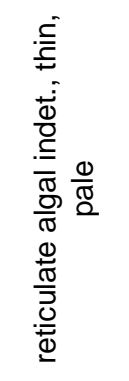 & 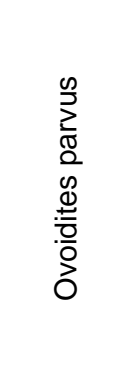 & 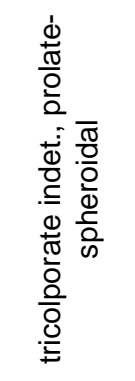 & 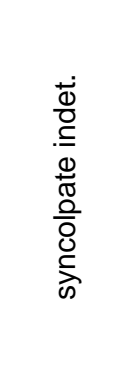 \\
\hline $\mathrm{P} 1$ & 2005JEA160C & 4 & 2 & 38 & 117 & $\mathrm{n}$ & 25 & & & & & 4 & $\mathrm{n}$ \\
\hline P2 & 2005JEA237B & 9 & $\mathrm{n}$ & 5 & 57 & 8 & 1 & 4 & & & & & \\
\hline P3 & 2005MBW415A & 24 & & 2 & 78 & 23 & 2 & & & & & & \\
\hline $\mathrm{P} 4$ & 2005Z235A & 34 & & & 79 & 3 & 21 & & & & & & \\
\hline P5 & 2005Z165B & 25 & 1 & 7 & 64 & 4 & 3 & & & & & & \\
\hline $\mathrm{P} 6$ & 2005Z171B & 1 & & 20 & 58 & 4 & 4 & & & & & & \\
\hline $\mathrm{P} 7$ & 2005LF124A & 33 & & 21 & 96 & 2 & 5 & & & & & & \\
\hline P8 & 2005Z47B & 1 & 4 & 4 & 86 & 1 & 92 & & & & & & \\
\hline P9 & 2005MBW232A & 4 & 1 & 24 & 106 & 16 & 17 & & & & $\mathrm{n}$ & & \\
\hline P10 & 2005MBW144A & 52 & & 1 & 33 & 13 & 6 & & & & & & \\
\hline P11 & 2005JEA210C & 5 & 3 & 4 & 100 & 5 & 9 & 1 & $\mathrm{n}$ & $n$ & & & \\
\hline P12 & 2005LF105A & 19 & & & 79 & 8 & 3 & & & & & & \\
\hline P13 & $2005 Z 36 C$ & 3 & $\mathrm{n}$ & & 5 & 17 & 9 & & 1 & & $\mathrm{n}$ & & \\
\hline P14 & 2005LF217D & & & & & & & & & & & & \\
\hline P15 & $2005 Z 229 A$ & & & & & & & & & & & & \\
\hline
\end{tabular}


Table E1. Raw pollen count data. Location coordinates were collected using a hand-held GPS unit (no differential correction was applied), and coordinates are presented in latitude and longitude (based on the NAD 27 Alaska datum) and in UTM coordinates (based on the Clark 1866 spheroid, NAD 27 datum, UTM zone 6 projection). Note: $n=$ pollen grain was noted in the sample but not included in the total counted grains of the sample-continued.

\begin{tabular}{|c|c|c|c|c|c|c|c|c|c|c|c|c|c|}
\hline & & $?$ & $?$ & $?$ & $?$ & $?$ & $?$ & $?$ & $?$ & $?$ & $?$ & $?$ & $?$ \\
\hline & & $\begin{array}{l}\text { angio- } \\
\text { sperm }\end{array}$ & angio-sperm & $\begin{array}{l}\text { angio- } \\
\text { sperm }\end{array}$ & $\begin{array}{l}\text { angio- } \\
\text { sperm }\end{array}$ & angio-sperm & $\begin{array}{l}\text { angio- } \\
\text { sperm }\end{array}$ & $\begin{array}{l}\text { angio- } \\
\text { sperm }\end{array}$ & $\begin{array}{l}\text { angio- } \\
\text { sperm }\end{array}$ & $\begin{array}{l}\text { angio- } \\
\text { sperm }\end{array}$ & $\begin{array}{l}\text { angio- } \\
\text { sperm }\end{array}$ & $\begin{array}{l}\text { angio- } \\
\text { sperm }\end{array}$ & $\begin{array}{l}\text { angio- } \\
\text { sperm }\end{array}$ \\
\hline & & Miocene & Miocene & Miocene & Miocene & Miocene & Miocene & Miocene & Miocene & Miocene & Miocene & Miocene & Miocene \\
\hline 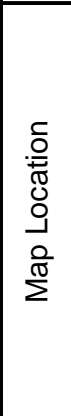 & 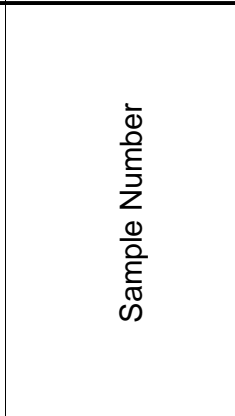 & 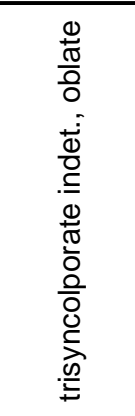 & 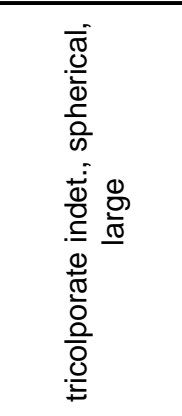 & 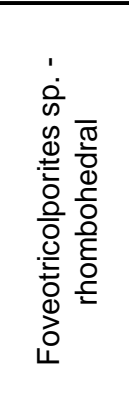 & 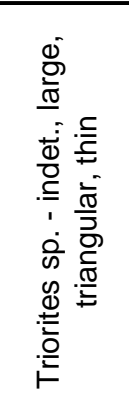 & 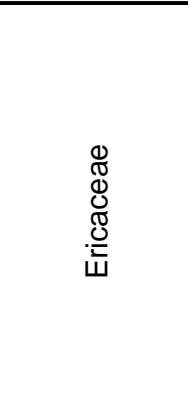 & 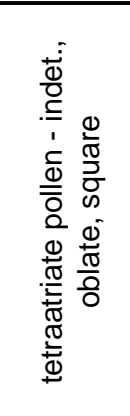 & 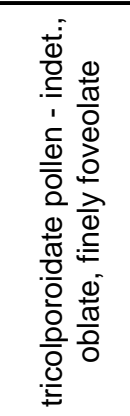 & 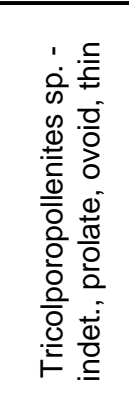 & 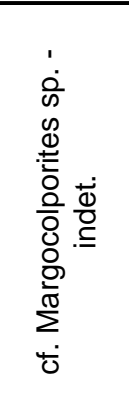 & 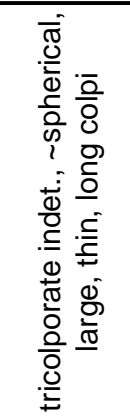 & 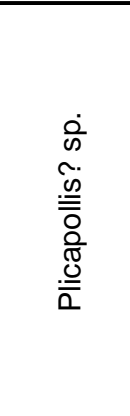 & 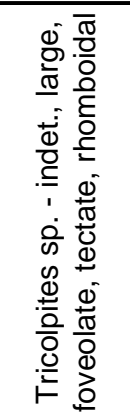 \\
\hline $\mathrm{P} 1$ & 2005JEA160C & $\mathrm{n}$ & & & & & & & & & & & \\
\hline $\mathrm{P} 2$ & 2005JEA237B & 1 & & & & & & & & & & & \\
\hline P3 & 2005MBW415A & & & & & 15 & & & & & & & \\
\hline P4 & $2005 Z 235 A$ & & & & & 5 & & & & & & & \\
\hline P5 & 2005Z165B & & & & & 2 & & & & & & & \\
\hline P6 & 2005Z171B & & & & & 1 & & & & & & & \\
\hline P7 & 2005LF124A & 1 & & & & 2 & & & & & & & \\
\hline P8 & 2005Z47B & & & & & & & & & & & & \\
\hline P9 & 2005MBW232A & & & & & $\mathrm{n}$ & 1 & $\mathrm{n}$ & $\mathrm{n}$ & $\mathrm{n}$ & & & \\
\hline P10 & 2005MBW144A & & & & & 7 & & & & & & & \\
\hline P11 & 2005JEA210C & & 2 & $\mathrm{n}$ & $\mathrm{n}$ & & & & & & & & \\
\hline P12 & 2005LF105A & & & & & $\mathrm{n}$ & & & & & & & \\
\hline P13 & $2005 Z 36 C$ & & & & & 1 & & & 3 & & 21 & $\mathrm{n}$ & $\mathrm{n}$ \\
\hline P14 & 2005LF217D & & & & & & & & & & & & \\
\hline P15 & 2005Z229A & & & & & & & & & & & & \\
\hline
\end{tabular}


Table E1. Raw pollen count data. Location coordinates were collected using a hand-held GPS unit (no differential correction was applied), and coordinates are presented in latitude and longitude (based on the NAD 27 Alaska datum) and in UTM coordinates (based on the Clark 1866 spheroid, NAD 27 datum, UTM zone 6 projection). Note: $n=$ pollen grain was noted in the sample but not included in the total counted grains of the sample-continued.

\begin{tabular}{|c|c|c|c|c|c|c|c|c|c|c|c|c|c|}
\hline & & $?$ & $?$ & $?$ & $?$ & $?$ & $?$ & $?$ & $?$ & $?$ & $?$ & $?$ & $?$ \\
\hline & & & & & wet & & & & & & & wet & \\
\hline & & $\begin{array}{l}\text { angio- } \\
\text { sperm }\end{array}$ & angio-sperm & fern & fern & fern & fern & fern & fern & fungal & fungal & fungal & $\begin{array}{l}\text { gymno- } \\
\text { sperm }\end{array}$ \\
\hline & & Miocene & Miocene & Miocene & Miocene & Miocene & Miocene & Miocene & Miocene & Miocene & Miocene & Miocene & Miocene \\
\hline 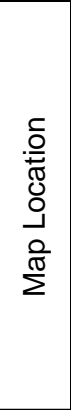 & 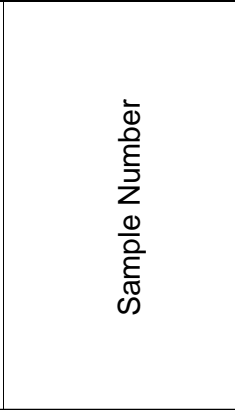 & 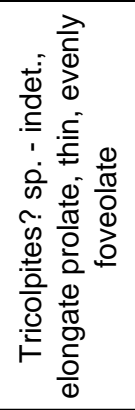 & 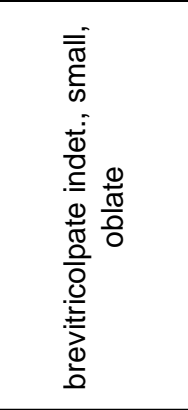 & 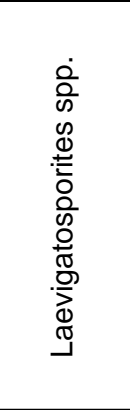 & 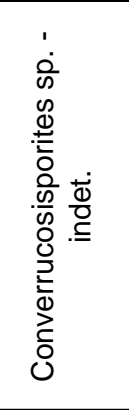 & 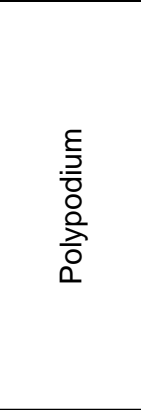 & $\begin{array}{l}\frac{\sigma}{\frac{\sigma}{U}} \\
\frac{\frac{U}{U}}{U} \\
\frac{0}{U}\end{array}$ & 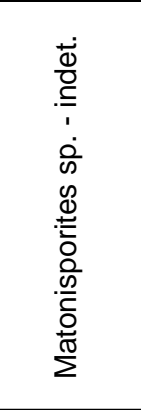 & 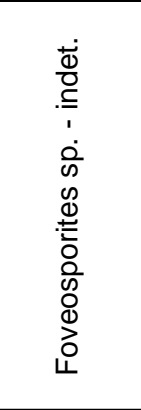 & 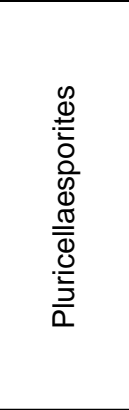 & 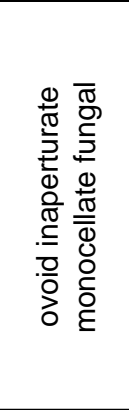 & 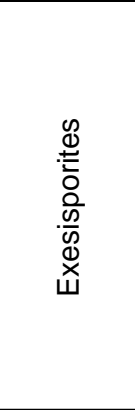 & 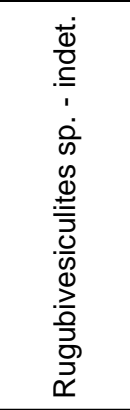 \\
\hline $\mathrm{P} 1$ & 2005JEA160C & & & 2 & $\mathrm{n}$ & $\mathrm{n}$ & & & & & & & $\mathrm{n}$ \\
\hline $\mathrm{P} 2$ & 2005JEA237B & & & 47 & & & & & & & & & 1 \\
\hline P3 & 2005MBW415A & & & 1 & & & & & & & $\mathrm{n}$ & & \\
\hline $\mathrm{P} 4$ & 2005Z235A & & & & & & & & & & & & \\
\hline $\mathrm{P} 5$ & 2005Z165B & & & 25 & & & 1 & & & & 1 & & \\
\hline P6 & 2005Z171B & & & 70 & & & & & $\mathrm{n}$ & & & & \\
\hline P7 & 2005LF124A & & & 5 & & & & & & & & & \\
\hline P8 & 2005Z47B & & & $\mathrm{n}$ & $\mathrm{n}$ & & $\mathrm{n}$ & & & & & & \\
\hline P9 & 2005MBW232A & & & 14 & & & & & & $\mathrm{n}$ & & & \\
\hline P10 & 2005MBW144A & & & 10 & & & & & & & & & \\
\hline P11 & 2005JEA210C & & & 16 & & $\mathrm{n}$ & $\mathrm{n}$ & & & & & 2 & \\
\hline P12 & 2005LF105A & & & 17 & 1 & & & & & & & & \\
\hline P13 & $2005 Z 36 C$ & $\mathrm{n}$ & $\mathrm{n}$ & 4 & $\mathrm{n}$ & $\mathrm{n}$ & & $\mathrm{n}$ & & & & & \\
\hline P14 & 2005LF217D & & & 2 & & & & & & & & & \\
\hline P15 & 2005Z229A & & & 8 & & & & & & & & & \\
\hline
\end{tabular}


Table E1. Raw pollen count data. Location coordinates were collected using a hand-held GPS unit (no differential correction was applied), and coordinates are presented in latitude and longitude (based on the NAD 27 Alaska datum) and in UTM coordinates (based on the Clark 1866 spheroid, NAD 27 datum, UTM zone 6 projection). Note: $n=$ pollen grain was noted in the sample but not included in the total counted grains of the sample-continued.

\begin{tabular}{|c|c|c|c|c|c|c|c|c|c|c|}
\hline & & $?$ & $?$ & $?$ & $?$ & $?$ & $?$ & $?$ & $?$ & \\
\hline & & wet & & wet & & & & & & \\
\hline & & moss & moss (club) & $\begin{array}{l}\text { moss } \\
\text { (liver- } \\
\text { worts) }\end{array}$ & weeds & reworked & reworked & reworked & \begin{tabular}{|c|} 
reworked \\
angio- \\
sperm
\end{tabular} & \\
\hline & & Miocene & Miocene & Miocene & Miocene & Middle Tertiary & $\begin{array}{l}\text { Creta- } \\
\text { ceous }\end{array}$ & $\begin{array}{l}\text { Permo- } \\
\text { triassic }\end{array}$ & $\begin{array}{l}\text { Permo- } \\
\text { triassic } \\
\end{array}$ & \\
\hline 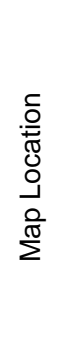 & 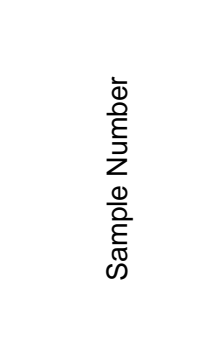 & 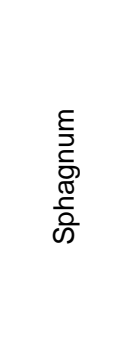 & 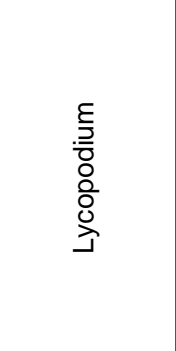 & 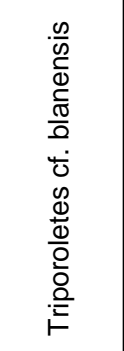 & $\begin{array}{l}\frac{\Xi}{\pi} \\
\frac{\pi}{0} \\
\frac{0}{\varepsilon} \\
\frac{0}{0} \\
ن\end{array}$ & 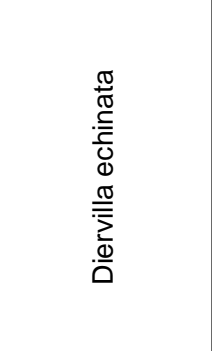 & 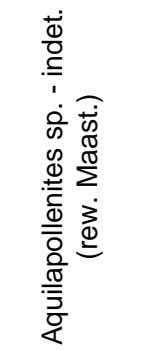 & 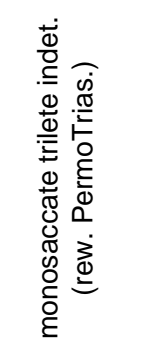 & 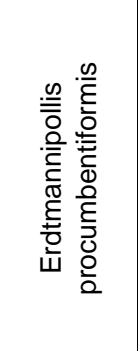 & 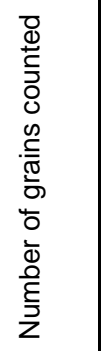 \\
\hline$\overline{P 1}$ & 2005JEA160C & & $\mathrm{n}$ & & $\mathrm{n}$ & & & & & 200 \\
\hline $\mathrm{P} 2$ & 2005JEA237B & 1 & 2 & & 1 & & & & & 200 \\
\hline P3 & 2005MBW415A & 6 & 1 & & & & & $\mathrm{n}$ & & 200 \\
\hline $\mathrm{P} 4$ & $2005 Z 235 A$ & 39 & 3 & & & & & & & 76 \\
\hline P5 & 2005Z165B & 1 & 3 & & & & & & & 200 \\
\hline P6 & 2005Z171B & 2 & 3 & & & $\mathrm{n}$ & & & & 200 \\
\hline $\mathrm{P} 7$ & 2005LF124A & 1 & 6 & & & & & & & 200 \\
\hline $\mathrm{P} 8$ & 2005Z47B & & $\mathrm{n}$ & & & & & & & 200 \\
\hline P9 & 2005MBW232A & 1 & 2 & & & & & & & 200 \\
\hline P10 & 2005MBW144A & 6 & 1 & & & & & & & 200 \\
\hline P11 & 2005JEA210C & & 2 & $\mathrm{n}$ & & & $\mathrm{n}$ & & $\mathrm{n}$ & 200 \\
\hline $\mathrm{P} 12$ & 2005LF105A & 6 & 2 & & & & & & & 200 \\
\hline P13 & $2005 Z 36 C$ & 1 & $\mathrm{n}$ & & & & & & & 200 \\
\hline P14 & 2005LF217D & & & & & & & & & 3 \\
\hline P15 & 2005Z229A & & & & & & & & & 8 \\
\hline
\end{tabular}




\section{Appendix F}

\section{Energy and geochemical analyses of coal and coal ash}

Twenty-one samples of coal were collected for energy and geochemical analyses. The weathered layer was cleaned off of coal layers greater than 1 foot thick and a fresh channel sample was collected in doubled-up ziplock bags surrounded by packing tape. Sample information and apparent coal rank calculations are compiled in table F1. Coal energy analyses were performed to American Society of Testing Materials (ASTM) standards by R.L. Stull of Geochemical Testing (table F2). For information on ASTM standards, visit the ASTM website, http://www.astm.org/, or contact ASTM Customer Service at service@astm.org. For Annual Book of ASTM Standards volume information, refer to the standard's Document Summary page on the ASTM website. J.D. McCord at the USGS Energy Lab analyzed the major-, minor-, and trace-element composition of the coal and coal ash (table F3). Geochemical analyses were performed to American Society of Testing Materials (ASTM), International Standards Organization (ISO), Environmental Protection Agency (EPA), and USGS standards. Most elements were analyzed by inductively coupled plasma-mass spectroscopy (ICP-MS) or inductively coupled plasma-atomic emission spectroscopy (ICP-AES). Analytical methods and reporting limits are included in table F4. 
This page has intentionally been left blank. 


\begin{tabular}{|c|c|c|c|c|c|c|c|c|c|c|c|}
\hline $\begin{array}{c}\text { Map } \\
\text { Location }\end{array}$ & Sample Number & Latitude & Longitude & $\begin{array}{l}\text { UTM } \\
\text { Easting }\end{array}$ & $\begin{array}{l}\text { UTM } \\
\text { Northing }\end{array}$ & Formation & Lithology & $\begin{array}{l}\text { Apparent } \\
\text { Thickness }\end{array}$ & $\begin{array}{l}\text { Mineral- } \\
\text { Matter-Free } \\
\text { BTU }\end{array}$ & $\begin{array}{l}\text { Matter- } \\
\text { Free Fixed } \\
\text { Carbon \% }\end{array}$ & Apparent Coal Rank \\
\hline $\mathrm{C} 1$ & 2005LF124A & 64.035824 & -148.678539 & 418008 & 7101889 & Healy Creek & $\begin{array}{l}\text { platey lignite coal beds, bed thickness is variable but mostly } 8 \\
\mathrm{~cm} \text { thick }\end{array}$ & $1.5 \mathrm{~m}$ & 7692 & 46 & Lignite A \\
\hline $\mathrm{C} 2$ & 2005MBW232A & 64.042121 & -148.582048 & 422738 & 7102471 & Healy Creek & $\begin{array}{l}\text { black, breaks into smooth fractured pieces, interbedded with } \\
\text { thin, light brown claystone }\end{array}$ & unknown & 6957 & 46 & Lignite A \\
\hline C3 & 2005MBW266A & 64.035915 & -148.678463 & 418012 & 7101899 & Healy Creek & black, breaks with smooth surface & $>2.4 \mathrm{~m}$ & 7879 & 45 & Lignite A \\
\hline C4 & 2005Z36B & 64.125307 & -148.752381 & 414676 & 7111956 & Healy Creek & nearly horizontal seam of dark brown to black lignite & $30 \mathrm{~cm}$ & 6465 & 43 & Lignite A \\
\hline C5 & 2005Z38D & 64.124866 & -148.743541 & 415105 & 7111895 & Healy Creek & $\begin{array}{l}\text { seams vary from }<1 \text {-cm-thick discontinuous partings up to } 20- \\
\mathrm{cm} \text {-thick traceable beds; at least } 14 \text { beds }>5 \mathrm{~cm} \text { thick; some } \\
\text { coal with resin grains up to } 6 \mathrm{~mm}\end{array}$ & unknown & 7284 & 43 & Lignite A \\
\hline C6 & 2005Z47A & 64.102325 & -148.734638 & 415470 & 7109372 & Healy Creek & $\begin{array}{l}\text { base of coal outcrop is not exposed, interbedded silty } \\
\text { claystone } 2 \mathrm{~cm} \text { thick }\end{array}$ & $>2.4 \mathrm{~m}$ & 7996 & 42 & Lignite A \\
\hline $\mathrm{C} 7$ & 2005LF105A & 64.040906 & -148.639873 & 419910 & 7102406 & Healy Creek & platey coal & $0.6 \mathrm{~m}$ & 8679 & 46 & High-volatile Subbituminous C \\
\hline $\mathrm{C} 8$ & 2005JEA160B & 64.006314 & -148.761612 & 413865 & 7098723 & Lignite Creek & platey coal & $76 \mathrm{~cm}$ & 6767 & 39 & Lignite A \\
\hline C9 & 2005MBW245A & 64.029164 & -148.64557 & 419600 & 7101105 & Suntrana & $\begin{array}{l}\text { both burnt and unburnt coal are present; coal is black, planar } \\
\text { bedded, and smooth and slightly shiny on broken surfaces }\end{array}$ & unknown & 6972 & 41 & Lignite A \\
\hline C10 & 2005MBW415A & 64.046366 & -148.729501 & 415551 & 7103130 & Suntrana & $\begin{array}{l}\text { slightly conchoidal to mostly hackley fracturing coal; beds } \\
\text { slightly folded }\end{array}$ & $3.05 \mathrm{~m}$ & 8068 & 43 & Lignite A \\
\hline C11 & 2005Z155A & 64.011346 & -148.662115 & 418738 & 7099142 & Suntrana & coal seam & $45 \mathrm{~cm}$ & 7308 & 49 & Lignite A \\
\hline C12 & 2005Z167A & 64.011991 & -148.694866 & 417140 & 7099255 & Suntrana & $\begin{array}{l}\text { 5.6-cm-thick coal seam located } 1.4 \mathrm{~m} \text { above this coal seam } \\
\text { tops a fining upward cycle; base of bed is underwater }\end{array}$ & $1.34 \mathrm{~m}$ & 7707 & 44 & Lignite A \\
\hline C13 & 2005Z170A1 & 64.020545 & -148.699498 & 416938 & 7100214 & Suntrana & black lignite coal, top sample of three samples & $2.5 \mathrm{~m}$ & 7618 & 44 & Lignite A \\
\hline C14 & 2005Z170A2 & 64.020545 & -148.699498 & 416938 & 7100214 & Suntrana & $\begin{array}{l}\text { thick black outcrop of lignite coal, middle sample of three } \\
\text { samples }\end{array}$ & $4 \mathrm{~m}$ & 7975 & 44 & Lignite A \\
\hline C15 & 2005Z170A3 & 64.020545 & -148.699498 & 416938 & 7100214 & Suntrana & $\begin{array}{l}\text { black lignite coal, bottom sample of three samples; lowermost } \\
\text { sample is pretty clean, without obvious silt or ash layers; bed } \\
\text { looks horizontal, lower contact is with siltstone below. }\end{array}$ & $2-3 \mathrm{~m}$ & 6856 & 43 & Lignite A \\
\hline C16 & 2005MBW254A & 64.027424 & -148.662007 & 418791 & 7100932 & Suntrana & $\begin{array}{l}\text { black, smoothly fracturing, layered coal with minor brown clay } \\
\text { on partings }\end{array}$ & $1.52 \mathrm{~m}$ & 5973 & 40 & Lignite B \\
\hline C17 & 2005Z156C & 64.013001 & -148.667369 & 418487 & 7099332 & Suntrana & sand above and silt below; coal has tree roots going through it & $57 \mathrm{~cm}$ & 5438 & 38 & Lignite B \\
\hline C18 & 2005Z165A & 64.013015 & -148.684044 & 417672 & 7099356 & Suntrana & lignite coal crops out beneath 5 -cm-thick soil cover & $38 \mathrm{c}$ & 6133 & 42 & Lignite $B$ \\
\hline C19 & 2005Z171A & 64.021726 & -148.697523 & 417039 & 7100343 & Suntrana & unit overlies a gray chocolate brown siltstone & unknown & 6142 & 38 & Lignite B \\
\hline $\mathrm{C} 20$ & $2005 Z 171 C$ & 64.021726 & -148.697523 & 417039 & 7100343 & Suntrana & lignite coal & $1.6 \mathrm{~m}$ & 6261 & 39 & Lignite $B$ \\
\hline $\mathrm{C} 21$ & $2005 Z 236 \mathrm{~A}$ & 64.005587 & -148.726426 & 415578 & 7098584 & Suntrana & $\begin{array}{l}\text { 3-m-thick coal bed with slight warp to coal/sandstone contact; } \\
\text { slight ferricrete cementing of sandstone for } 3-4 \mathrm{~cm} \text { at upper }\end{array}$ & $3 \mathrm{~m}$ & 8371 & 45 & High-volatile Subbituminous C \\
\hline
\end{tabular}


This page intentionally left blank. 


\begin{tabular}{|c|c|c|c|c|c|c|c|c|c|c|c|c|c|c|c|c|c|c|c|c|c|c|}
\hline & 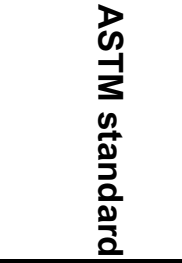 & 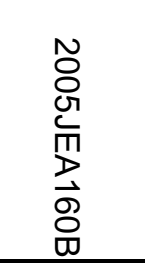 & $\begin{array}{l}\text { Oे } \\
\text { on } \\
T \\
\overrightarrow{0} \\
\text { Oi }\end{array}$ & $\begin{array}{l}\text { Oे } \\
\text { or } \\
\bar{T} \\
\vec{N} \\
\stackrel{N}{D}\end{array}$ & 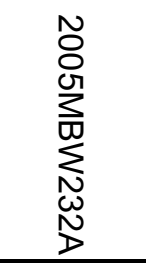 & 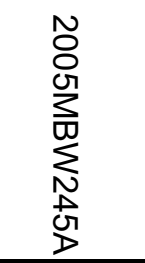 & 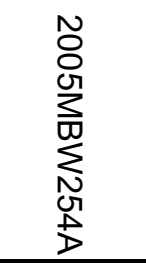 & 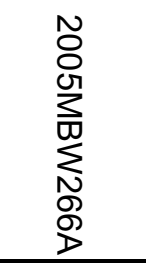 & 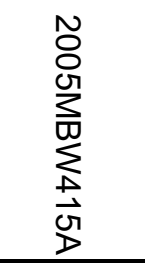 & $\begin{array}{l}\text { No } \\
\text { O } \\
\text { N } \\
\text { ज़ } \\
\text { ग }\end{array}$ & 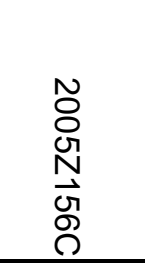 & $\begin{array}{l}\text { Oे } \\
\text { O } \\
\text { N } \\
\text { Oे } \\
\text { D }\end{array}$ & $\begin{array}{l}\text { Oे } \\
\text { O } \\
N \\
\stackrel{D}{D} \\
D\end{array}$ & $\begin{array}{l}\text { Oे } \\
\text { o } \\
\text { N } \\
\stackrel{0}{0} \\
D\end{array}$ & $\begin{array}{l}\text { Oे } \\
\text { O } \\
\text { N } \\
\text { D } \\
\text { 怘 }\end{array}$ & $\begin{array}{l}\text { Oे } \\
\text { O } \\
\stackrel{2}{*} \\
\stackrel{0}{\omega}\end{array}$ & $\begin{array}{l}\text { Oे } \\
\text { O } \\
\stackrel{N}{J} \\
\stackrel{D}{D}\end{array}$ & $\begin{array}{l}\text { Oे } \\
\text { O } \\
\stackrel{N}{N} \\
\vec{N}\end{array}$ & $\begin{array}{l}\text { Oे } \\
\text { O } \\
N \\
\text { D } \\
\text { D }\end{array}$ & 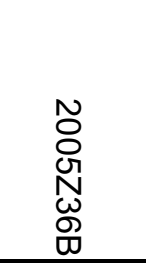 & 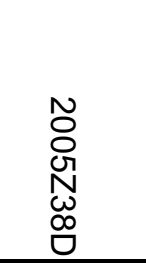 & $\begin{array}{l}\text { O } \\
\text { O } \\
N \\
\text { A } \\
\end{array}$ \\
\hline Air Dry Loss & & $25.99 \%$ & $17.45 \%$ & $24.12 \%$ & $22.67 \%$ & $27.97 \%$ & $19.11 \%$ & $21.92 \%$ & $22.46 \%$ & $25.57 \%$ & $25.17 \%$ & $30.34 \%$ & $24.10 \%$ & $21.30 \%$ & $17.21 \%$ & $22.55 \%$ & $19.78 \%$ & $21.81 \%$ & $16.70 \%$ & $31.16 \%$ & $23.61 \%$ & $20.05 \%$ \\
\hline Residual Moisture & & $6.68 \%$ & $9.33 \%$ & $5.91 \%$ & $6.34 \%$ & $7.97 \%$ & $2.65 \%$ & $5.63 \%$ & $10.99 \%$ & $6.78 \%$ & $7.97 \%$ & $9.46 \%$ & $12.05 \%$ & $9.41 \%$ & $10.64 \%$ & $7.07 \%$ & $7.80 \%$ & $5.94 \%$ & $11.70 \%$ & $10.67 \%$ & $10.15 \%$ & $6.45 \%$ \\
\hline $\begin{array}{l}\text { Proximate Analysis } \\
\text { As Received }\end{array}$ & D3172 & & & & & & & & & & & & & & & & & & & & & \\
\hline Moisture & & 30.93 & 25.15 & 28.6 & 27.57 & 33.71 & 21.25 & 26.32 & 30.98 & 30.62 & 31.13 & 36.93 & 33.25 & 28.71 & 26.02 & 28.03 & 26.04 & 26.45 & 26.45 & 38.51 & 31.36 & 25.21 \\
\hline Ash & & 26.42 & 11.38 & 20.38 & 32.46 & 6.02 & 54.81 & 23.56 & 2.82 & 21.76 & 35.87 & 10.15 & 4.36 & 17.56 & 19.91 & 32.2 & 43.86 & 43.36 & 7.75 & 12.45 & 19.74 & 26.12 \\
\hline Volatile Matter & & 27.04 & 34.91 & 28.45 & 22.7 & 35.89 & 16.15 & 28.46 & 37.76 & 25.25 & 21.42 & 31.01 & 34.95 & 30.59 & 31.06 & 23.85 & 19.92 & 19.81 & 36.42 & 28.58 & 28.59 & 29.26 \\
\hline Fixed Carbon & & 15.61 & 28.56 & 22.57 & 17.27 & 24.38 & 7.79 & 21.66 & 28.44 & 22.37 & 11.58 & 21.91 & 27.44 & 23.14 & 23.01 & 15.92 & 10.18 & 10.38 & 29.38 & 20.46 & 20.31 & 19.41 \\
\hline \multicolumn{23}{|l|}{ Dry } \\
\hline Moisture & & - & - & - & - & - & - & - & - & - & - & - & - & - & - & - & - & - & - & - & - & \\
\hline Ash & & 38.26 & 15.2 & 28.55 & 44.81 & 9.08 & 69.59 & 31.98 & 4.09 & 31.37 & 52.08 & 16.09 & 6.53 & 24.64 & 26.91 & 44.74 & 59.31 & 58.95 & 10.53 & 20.25 & 28.76 & 34.92 \\
\hline Volatile Matter & & 39.14 & 46.64 & 39.84 & 31.35 & 54.15 & 20.51 & 38.62 & 54.7 & 36.4 & 31.1 & 49.16 & 52.36 & 42.91 & 41.99 & 33.13 & 26.93 & 26.93 & 49.51 & 46.48 & 41.66 & 39.12 \\
\hline Fixed Carbon & & 22.6 & 38.16 & 31.61 & 23.84 & 36.77 & 9.9 & 29.4 & 41.21 & 32.23 & 16.82 & 34.75 & 41.11 & 32.45 & 31.1 & 22.13 & 13.76 & 14.12 & 39.96 & 33.27 & 29.58 & 25.96 \\
\hline \multicolumn{23}{|l|}{ Dry Ash-Free } \\
\hline Moisture & & - & - & - & - & - & - & - & - & - & - & - & - & - & - & - & - & - & - & - & - & - \\
\hline Ash & & & & & & & & & & & & & & & & & & 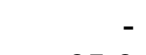 & -2 & & & \\
\hline Volatile Matter & & 63.4 & 55 & 55.76 & 56.8 & 59.56 & 67.47 & 56.78 & 57.03 & 53.03 & 64.9 & 58.59 & 56.02 & 56.94 & 57.45 & 59.96 & 66.18 & 65.6 & 55.34 & 58.28 & 58.48 & 60.12 \\
\hline Fixed Carbon & & 36.6 & 45 & 44.24 & 43.2 & 40.44 & 32.53 & 43.22 & 42.97 & 46.97 & 35.1 & 41.41 & 43.98 & 43.06 & 42.55 & 40.04 & 33.82 & 34.4 & 44.66 & 41.72 & 41.52 & 39.88 \\
\hline \multicolumn{23}{|l|}{$\begin{array}{l}\text { ULTIMATE ANALYSIS } \\
\text { As Received }\end{array}$} \\
\hline Hydrogen & D5373 & 6.65 & 6.36 & 5.94 & 5.08 & 6.75 & 3.41 & 5.72 & 7.1 & 5.77 & 4.92 & 6.46 & 7.04 & 6.01 & 5.79 & 5.23 & 4.44 & 4.54 & 6.53 & 6.85 & 6.21 & 5.67 \\
\hline Carbon & D5373 & 28.16 & 44.6 & 34.68 & 26.36 & 39.43 & 14.45 & 34.21 & 45.77 & 32.49 & 20.49 & 33.58 & 43.34 & 36.03 & 36.46 & 25.76 & 18.92 & 19.2 & 45.5 & 32.64 & 32.88 & 32.55 \\
\hline Nitrogen & D5373 & 1.14 & 0.65 & 0.42 & 0.36 & 0.56 & 0.33 & 0.4 & 0.44 & 0.49 & 0.49 & 0.47 & 0.49 & 0.49 & 0.57 & 0.43 & 0.41 & 0.41 & 0.58 & 0.4 & 0.42 & 0.53 \\
\hline Sulfur & D4239-02 & 0.3 & 0.26 & 0.17 & 0.15 & 0.21 & 0.22 & 0.16 & 0.16 & 0.28 & 0.12 & 0.13 & 0.11 & 0.2 & 0.17 & 0.19 & 0.2 & 0.18 & 0.2 & 0.67 & 0.66 & 0.15 \\
\hline Oxygen & D3176 & 37.33 & 36.75 & 38.41 & 35.59 & 47.03 & 26.78 & 35.95 & 43.71 & 39.21 & 38.11 & 49.21 & 44.66 & 39.71 & 37.1 & 36.19 & 32.17 & 32.31 & 39.44 & 46.99 & 40.09 & 34.98 \\
\hline Ash & D3174-02 & 26.42 & 11.38 & 20.38 & 32.46 & 6.02 & 54.81 & 23.56 & 2.82 & 21.76 & 35.87 & 10.15 & 4.36 & 17.56 & 19.91 & 32.2 & 43.86 & 43.36 & 7.75 & 12.45 & 19.74 & 26.12 \\
\hline \multicolumn{23}{|l|}{ Dry } \\
\hline Hydrogen & D5373 & 4.61 & 4.74 & 3.84 & 2.76 & 4.49 & 1.31 & 3.77 & 5.26 & 3.38 & 2.08 & 3.69 & 4.97 & 3.93 & 3.89 & 2.9 & 2.06 & 2.15 & 4.86 & 4.13 & 3.93 & 3.81 \\
\hline Carbon & D5373 & 40.77 & 59.59 & 48.57 & 36.39 & 59.48 & 18.35 & 46.43 & 66.31 & 46.82 & 29.75 & 53.25 & 64.92 & 50.55 & 49.28 & 35.79 & 25.57 & 26.11 & 61.87 & 53.08 & 47.9 & 43.52 \\
\hline Nitrogen & D5373 & 1.65 & 0.87 & 0.58 & 0.5 & 0.85 & 0.42 & 0.54 & 0.64 & 0.71 & 0.71 & 0.75 & 0.73 & 0.68 & 0.77 & 0.6 & 0.55 & 0.55 & 0.79 & 0.65 & 0.61 & 0.71 \\
\hline Sulfur & D4239-02 & 0.43 & 0.35 & 0.24 & 0.21 & 0.32 & 0.28 & 0.21 & 0.22 & 0.41 & 0.17 & 0.2 & 0.17 & 0.28 & 0.24 & 0.26 & 0.27 & 0.24 & 0.27 & 1.09 & 0.96 & 0.2 \\
\hline Oxygen & D3176 & 14.28 & 19.25 & 18.22 & 15.33 & 25.78 & 10.05 & 17.07 & 23.48 & 17.31 & 15.21 & 26.02 & 22.68 & 19.92 & 18.91 & 15.71 & 12.24 & 12 & 21.68 & 20.8 & 17.84 & 16.84 \\
\hline Ash & D3174-02 & 38.26 & 15.2 & 28.55 & 44.81 & 9.08 & 69.59 & 31.98 & 4.09 & 31.37 & 52.08 & 16.09 & 6.53 & 24.64 & 26.91 & 44.74 & 59.31 & 58.95 & 10.53 & 20.25 & 28.76 & 34.92 \\
\hline \multicolumn{23}{|l|}{ Dry Ash-Fre } \\
\hline Hydroge & D5373 & 7.47 & 5.59 & 5.37 & 4.99 & 4.93 & 4.3 & 5.55 & 5.48 & 4.93 & 4.35 & 4.4 & 5.32 & 5.21 & 5.33 & 5.26 & 5.06 & 5.25 & 5.43 & 5.17 & 5.52 & 5.86 \\
\hline Carbon & D5373 & 66.04 & 70.27 & 67.98 & 65.93 & 65.42 & 60.34 & 68.27 & 69.13 & 68.22 & 62.09 & 63.46 & 69.46 & 67.07 & 67.43 & 64.77 & 62.85 & 63.61 & 69.15 & 66.56 & 67.24 & 66.87 \\
\hline Nitrogen & D5373 & 2.67 & 1.03 & 0.82 & 0.91 & 0.93 & 1.39 & 0.79 & 0.67 & 1.03 & 1.47 & 0.9 & 0.78 & 0.91 & 1.06 & 1.09 & 1.36 & 1.35 & 0.89 & 0.81 & 0.86 & 1.08 \\
\hline Sulfur & D4239-02 & 0.69 & 0.42 & 0.34 & 0.39 & 0.35 & 0.91 & 0.31 & 0.23 & 0.59 & 0.36 & 0.24 & 0.18 & 0.37 & 0.32 & 0.47 & 0.67 & 0.6 & 0.3 & 1.36 & 1.34 & 0.31 \\
\hline Oxygen & D3176 & 23.13 & 22.69 & 25.49 & 27.78 & 28.37 & 33.06 & 25.08 & 24.49 & 25.23 & 31.73 & 31 & 24.26 & 26.44 & 25.86 & 28.41 & 30.06 & 29.19 & 24.23 & 26.1 & 25.04 & 25.88 \\
\hline Ash & D3174-02 & - & 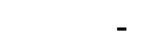 & 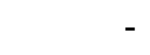 & 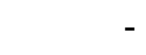 & 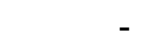 & - & - & - & & & 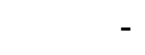 & - & - & - & - & - & - & 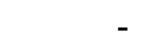 & 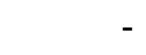 & & \\
\hline
\end{tabular}




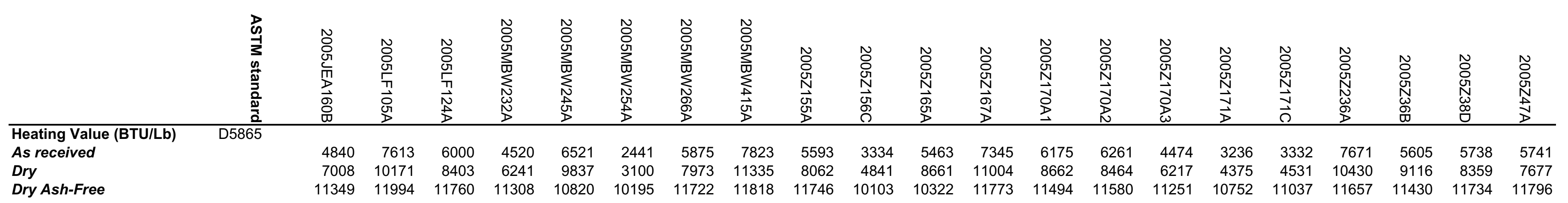

FORMS OF SULFUR

As Received

Sulfate Sulfur

Pyritic Sulfur

\section{Dry}

Sulfate Sulfur

Pyritic Sulfur

Organic Sulfur

\section{Dry Ash Free}

Sulfate Sulfur

Pyritic Sulfur

Organinc Sulfur

Free Selling Index

Equilibrium Moisture
D2492

\begin{tabular}{|c|c|c|c|c|c|c|c|c|c|c|c|c|c|c|c|c|c|c|c|}
\hline 0.01 & 0.01 & 0.01 & 0.01 & 0.01 & 0.01 & 0.02 & 0.01 & 0 & 0.01 & 0.01 & 0.02 & 0.02 & 0.02 & 0.01 & 0.02 & 0.01 & 0.01 & 0.01 & 0.02 \\
\hline 0.02 & 0.06 & 0.02 & 0.02 & 0.02 & 0.01 & 0.01 & 0.01 & 0.01 & 0.04 & 0.01 & 0.01 & 0.01 & 0.02 & 0.02 & 0.01 & 0.04 & 0.01 & 0.01 & 0.02 \\
\hline 27 & 0.19 & 0.14 & 0.12 & 0.18 & 0.2 & 0.13 & 0.14 & 0.27 & 0.07 & 0.11 & 0.08 & 0.17 & 0.28 & 0.16 & 0.17 & 0.13 & 0.18 & 0.65 & 0.62 \\
\hline
\end{tabular}

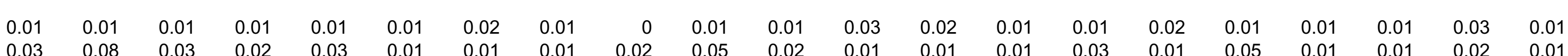

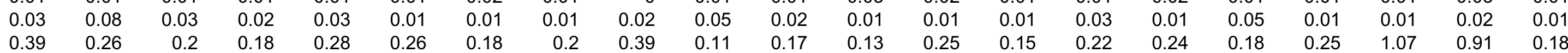

$\begin{array}{lllllllllllllllllllllll}0.02 & 0.01 & 0.01 & 0.02 & 0.01 & 0.03 & 0.03 & 0.01 & 0 & 0.02 & 0.01 & 0.04 & 0.03 & 0.01 & 0.02 & 0.05 & 0.03 & 0.01 & 0.01 & 0.05 & 0.02\end{array}$

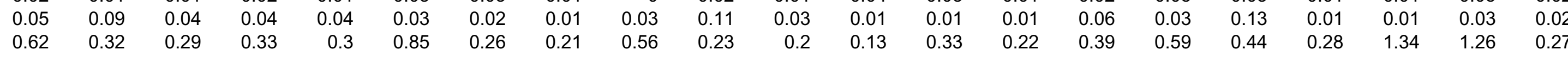
$\begin{array}{lrrrrrrrrrrrrrrrrrrrrr}\text { D720-91 } & 0 & 0 & 0 & 0 & 0 & 0 & 0 & 0 & 0 & 0 & 0 & 0 & 0 & 0 & 0 & 0 & 0 & 0 & 0 & 0 & 0 \\ \text { D1412-03 } & 21.79 & 25.56 & 28.16 & 26.83 & 22.89 & 17.28 & 29.8 & 25.93 & 28.71 & 23.49 & 34.01 & 27.29 & 28.54 & 26.98 & 27.38 & 24.62 & 23.24 & 29.67 & 36.99 & 25.71 & 22.49\end{array}$ 
Table F3. Major-, minor-, and trace-element geochemical analyses of coal and coal ash from samples collected in the Liberty Bell area, Fairbanks A-4 Quadrangle, Alaska. Note: < RPT = value was less than reported limit.

\begin{tabular}{|c|c|c|c|c|c|c|c|c|c|c|c|c|c|c|}
\hline Sample Number & $\begin{array}{c}\text { Moisture } \\
\% \\
\end{array}$ & $\begin{array}{c}\mathrm{Hg} \\
\mathrm{ppm}\end{array}$ & $\begin{array}{c}\text { Se } \\
\text { ppm }\end{array}$ & $\begin{array}{c}\mathrm{Cl} \\
\mathrm{ppm}\end{array}$ & $\begin{array}{l}\mathrm{S} \\
\%\end{array}$ & $\begin{array}{l}\mathrm{Al} \\
\% \\
\end{array}$ & $\begin{array}{c}\mathrm{Ba} \\
\mathrm{ppm}\end{array}$ & $\begin{array}{c}\mathrm{Be} \\
\mathrm{ppm}\end{array}$ & $\begin{array}{c}\mathrm{Ca} \\
\% \\
\end{array}$ & $\begin{array}{c}\text { Co } \\
\text { ppm }\end{array}$ & $\begin{array}{c}\mathrm{Cr} \\
\mathrm{ppm}\end{array}$ & $\begin{array}{c}\mathrm{Cu} \\
\mathrm{ppm}\end{array}$ & $\begin{array}{c}\mathrm{Fe} \\
\% \\
\end{array}$ & $\begin{array}{l}\mathrm{K} \\
\% \\
\end{array}$ \\
\hline 2005JEA160B & 7.26 & 0.144 & 1.03 & 17.8 & 0.417 & 11.2 & 1380 & 3.39 & 5.2 & 14.5 & 168 & 179 & 2.3 & 1.07 \\
\hline 2005LF105A & 9.33 & 0.122 & 0.337 & 50.3 & 0.359 & 12.5 & 3510 & 5.47 & 6.74 & 51.2 & 185 & 201 & 3.06 & 1.24 \\
\hline 2005LF124A & 6.37 & 0.14 & 0.452 & 31.2 & 0.243 & 14.4 & 2340 & 4.09 & 3.07 & 43.2 & 215 & 111 & 1.85 & 2.08 \\
\hline 2005MBW232A & 6.49 & 0.175 & 0.472 & 13.4 & 0.202 & 13.2 & 3210 & 3.83 & 1.43 & 17.6 & 227 & 108 & 1.54 & 2.77 \\
\hline 2005MBW245A & 8.45 & 0.106 & 0.244 & 17.8 & 0.266 & 9.74 & 12000 & 7.29 & 16.9 & 61.7 & 135 & 151 & 5.55 & 0.87 \\
\hline 2005MBW254A & 2.85 & 0.355 & 0.313 & 23.2 & 0.267 & 10.1 & 784 & 2.09 & 0.402 & 4.26 & 24.6 & 10.8 & 0.93 & 2.53 \\
\hline 2005MBW266A & 6.13 & 0.14 & 0.466 & 10.8 & 0.213 & 14 & 2100 & 3.58 & 2.82 & 29.7 & 193 & 100 & 1.25 & 2.28 \\
\hline 2005MBW415A & 10.6 & 0.076 & $<\mathrm{RPT}$ & 12.6 & 0.202 & 9.04 & 6800 & 45.2 & 20.7 & 20.4 & 73.3 & 84.2 & 7.6 & 0.551 \\
\hline 2005Z155A & 7.21 & 0.258 & 1.03 & 10.7 & 0.436 & 7.2 & 2730 & 3.74 & 3.71 & 48.1 & 194 & 122 & 1.76 & 1.28 \\
\hline 2005Z156C & 7.7 & 1.25 & 1.41 & 19.1 & 0.142 & 11.9 & 2310 & 5.09 & 2.87 & 24.9 & 147 & 111 & 2.52 & 1.79 \\
\hline 2005Z165A & 9.43 & 0.125 & $<\mathrm{RPT}$ & 19.5 & 0.2 & 9.84 & 2900 & 3.12 & 12.3 & 29.6 & 137 & 116 & 4.19 & 1.04 \\
\hline $2005 Z 167 A$ & 11.9 & 0.19 & $<\mathrm{RPT}$ & 17.8 & 0.134 & 5.57 & 6040 & 18.7 & 25.8 & 202 & 120 & 117 & 8.02 & 0.268 \\
\hline 2005Z170A1 & 9.21 & 0.116 & 0.312 & 13.5 & 0.208 & 11.4 & 1890 & 3.16 & 6.75 & 28.3 & 163 & 150 & 2.47 & 1.27 \\
\hline 2005Z170A2 & 10.1 & 0.123 & 0.31 & 10.6 & 0.187 & 11.4 & 1790 & 2.82 & 6.9 & 22.1 & 149 & 135 & 2.46 & 1.13 \\
\hline 2005Z170A3 & 6.96 & 0.138 & 0.462 & 11 & 0.218 & 12 & 1150 & 3.18 & 3.04 & 16.7 & 155 & 112 & 3.02 & 1.51 \\
\hline 2005Z171A & 7.41 & 0.138 & 1.48 & $<\mathrm{RPT}$ & 0.223 & 11.8 & 1060 & 3.76 & 2.73 & 16.5 & 163 & 98.9 & 1.96 & 1.51 \\
\hline 2005Z171C & 5.75 & 0.145 & 1.54 & 12.4 & 0.199 & 11.2 & 1030 & 3.54 & 2.59 & 15.1 & 155 & 119 & 2.5 & 1.63 \\
\hline 2005Z236A & 10.3 & 0.11 & 0.24 & 10.4 & 0.209 & 9.15 & 3340 & 4.78 & 17.3 & 38.4 & 140 & 148 & 4.13 & 0.723 \\
\hline 2005Z36B & 9.82 & 0.178 & 2.9 & 61 & 0.974 & 8.67 & 3490 & 26.4 & 6.01 & 87.7 & 60.7 & 171 & 2.96 & 2.16 \\
\hline 2005Z38D & 9.4 & 0.24 & 1.76 & 26.8 & 0.902 & 11.5 & 6530 & 16.6 & 1.93 & 40.4 & 76.5 & 146 & 2.43 & 1.95 \\
\hline 2005Z47A & 6.12 & 0.18 & $<\mathrm{RPT}$ & 19.5 & 0.181 & 15.5 & 2850 & 3.37 & 1.77 & 8.3 & 39.1 & 30.7 & 2.66 & 2.52 \\
\hline
\end{tabular}



= value was less than reported limit-continued.

\begin{tabular}{|c|c|c|c|c|c|c|c|c|c|c|c|c|c|c|}
\hline Sample Number & $\begin{array}{c}\text { Li } \\
\text { ppm }\end{array}$ & $\begin{array}{c}\mathrm{Mg} \\
\%\end{array}$ & $\begin{array}{c}\mathrm{Mn} \\
\mathrm{ppm}\end{array}$ & $\begin{array}{c}\mathrm{Na} \\
\%\end{array}$ & $\begin{array}{c}\mathrm{Ni} \\
\mathrm{ppm}\end{array}$ & $\begin{array}{l}\mathrm{P} \\
\%\end{array}$ & $\begin{array}{l}\mathrm{S} \\
\%\end{array}$ & $\begin{array}{c}\text { Sc } \\
\text { ppm }\end{array}$ & $\begin{array}{l}\mathrm{Si} \\
\%\end{array}$ & $\begin{array}{c}\mathrm{Sr} \\
\mathrm{ppm}\end{array}$ & $\begin{array}{c}\text { Th } \\
\text { ppm }\end{array}$ & $\begin{array}{l}\mathrm{Ti} \\
\%\end{array}$ & $\begin{array}{c}\mathrm{V} \\
\mathrm{ppm}\end{array}$ & $\begin{array}{c}\mathrm{Y} \\
\mathrm{ppm}\end{array}$ \\
\hline 2005JEA160B & 51.1 & 1.47 & 1010 & 0.226 & 45.4 & 0.0217 & 1.03 & 32.4 & 26.5 & 155 & 15.4 & 0.639 & 274 & 48.3 \\
\hline 2005LF105A & 69.3 & 1.1 & 467 & 0.0848 & 141 & 0.0319 & 2.18 & 43.2 & 23.7 & 949 & 30.5 & 0.615 & 302 & 57 \\
\hline 2005LF124A & 92.7 & 0.956 & 401 & 0.0974 & 174 & 0.0252 & 0.815 & 35.2 & 25.8 & 352 & 31.6 & 0.701 & 292 & 33.5 \\
\hline 2005MBW232A & 85.7 & 0.869 & 59.8 & 0.102 & 49.3 & 0.0235 & 0.468 & 31.8 & 27.9 & 272 & 23.9 & 0.626 & 344 & 30.4 \\
\hline 2005MBW245A & 66.3 & 1.22 & 244 & 0.038 & 98.4 & 0.0427 & 3.2 & 33.5 & 14.9 & 2460 & 24.8 & 0.453 & 229 & 91.2 \\
\hline 2005MBW254A & 33.5 & 0.433 & 152 & 0.0453 & 10.5 & 0.0285 & 0.199 & 6.86 & 33 & 69.7 & 13.7 & 0.222 & 34.6 & 11.1 \\
\hline 2005MBW266A & 81.1 & 0.984 & 218 & 0.1 & 88.4 & 0.0203 & 0.636 & 31.9 & 27.5 & 332 & 24.8 & 0.743 & 279 & 29.1 \\
\hline 2005MBW415A & 60.6 & 2.61 & 2190 & 0.0574 & 48.4 & 0.0502 & 5.14 & 24.8 & 10.4 & 2200 & 18.7 & 0.285 & 156 & 48.8 \\
\hline $2005 Z 155 A$ & 56.2 & 0.889 & 199 & 0.0536 & 118 & 0.123 & 1.25 & 25.2 & 31.7 & 535 & 22.1 & 0.398 & 194 & 40.8 \\
\hline 2005Z156C & 45.2 & 0.68 & 656 & 0.14 & 34.4 & 0.0222 & 0.395 & 29.7 & 28.7 & 450 & 29.9 & 0.592 & 247 & 44.8 \\
\hline $2005 Z 165 A$ & 50 & 1.68 & 2970 & 0.114 & 59.3 & 0.0273 & 1.28 & 31.4 & 22.3 & 1150 & 17.4 & 0.652 & 234 & 35.6 \\
\hline 2005Z167A & 48.8 & 3.76 & 4460 & 0.128 & 697 & 0.0338 & 3.04 & 21.5 & 10.2 & 2840 & $<\mathrm{RPT}$ & 0.486 & 137 & 102 \\
\hline 2005Z170A1 & 48.2 & 1.35 & 1100 & 0.13 & 67.4 & 0.0388 & 1.15 & 31 & 25.3 & 563 & 14.6 & 0.615 & 276 & 34.8 \\
\hline 2005Z170A2 & 46.7 & 1.32 & 868 & 0.102 & 60.2 & 0.0501 & 0.907 & 30.1 & 25.9 & 568 & 12.3 & 0.627 & 242 & 34.6 \\
\hline 2005Z170A3 & 49 & 1.11 & 770 & 0.238 & 58.8 & $<\mathrm{RPT}$ & 0.641 & 27.7 & 28.6 & 249 & 10.1 & 0.577 & 230 & 30.4 \\
\hline 2005Z171A & 56.9 & 0.976 & 377 & 0.576 & 54.8 & $<\mathrm{RPT}$ & 0.48 & 28.8 & 29.7 & 183 & 11.1 & 0.669 & 248 & 41.8 \\
\hline 2005Z171C & 51.8 & 1.13 & 342 & 0.636 & 51.1 & $<\mathrm{RPT}$ & 0.444 & 28.2 & 28.9 & 177 & 11.7 & 0.594 & 247 & 39.7 \\
\hline 2005Z236A & 48.7 & 2.6 & 2860 & 0.114 & 79.5 & 0.0261 & 2.6 & 35.4 & 16.5 & 1860 & 20.9 & 0.534 & 253 & 54.7 \\
\hline 2005Z36B & 38.4 & 1.29 & 783 & 0.398 & 564 & 0.0439 & 3.88 & 36.4 & 24.7 & 423 & 33.5 & 0.257 & 255 & 295 \\
\hline 2005Z38D & 67.2 & 0.871 & 254 & 0.36 & 78.5 & 0.0558 & 1.35 & 35.3 & 28.6 & 227 & 36.8 & 0.546 & 336 & 133 \\
\hline $2005 Z 47 A$ & 62.5 & 1.18 & 340 & 0.076 & 19.9 & 0.271 & 0.511 & 14.8 & 25.5 & 178 & 39.1 & 0.365 & 67 & 24.3 \\
\hline
\end{tabular}


Table F3. Major-, minor-, and trace-element geochemical analyses of coal and coal ash from samples collected in the Liberty Bell area, Fairbanks A-4 Quadrangle, Alaska. Note: < RPT = value was less than reported limit-continued.

\begin{tabular}{|c|c|c|c|c|c|c|c|c|c|c|c|c|c|c|}
\hline Sample Number & $\begin{array}{c}\mathrm{Ag} \\
\mathrm{ppm}\end{array}$ & $\begin{array}{c}\text { As } \\
\text { ppm }\end{array}$ & $\begin{array}{c}\text { Au } \\
\text { ppm }\end{array}$ & $\begin{array}{c}\mathrm{Bi} \\
\mathrm{ppm}\end{array}$ & $\begin{array}{c}\text { Cd } \\
\text { ppm }\end{array}$ & $\begin{array}{c}\mathrm{Cs} \\
\mathrm{ppm}\end{array}$ & $\begin{array}{c}\mathrm{Ga} \\
\mathrm{ppm}\end{array}$ & $\begin{array}{c}\text { Ge } \\
\text { ppm }\end{array}$ & $\begin{array}{c}\text { Mo } \\
\text { ppm }\end{array}$ & $\begin{array}{c}\mathrm{Nb} \\
\mathrm{ppm}\end{array}$ & $\begin{array}{c}\mathrm{Pb} \\
\mathrm{ppm}\end{array}$ & $\begin{array}{c}\mathrm{Rb} \\
\mathrm{ppm}\end{array}$ & $\begin{array}{c}\mathrm{Sb} \\
\mathrm{ppm}\end{array}$ & $\begin{array}{c}\text { Sn } \\
\text { ppm }\end{array}$ \\
\hline 2005JEA160B & $<\mathrm{RPT}$ & 3.26 & $<\mathrm{RPT}$ & 0.284 & 0.229 & 8.12 & 18.4 & 2.57 & 4.61 & 7.02 & 17.3 & 85.9 & 1.14 & 4.13 \\
\hline 2005LF105A & $<\mathrm{RPT}$ & 2.73 & $<\mathrm{RPT}$ & 0.202 & 0.192 & 1.99 & 11.7 & 2.42 & 6.96 & 9.33 & 16.2 & 31.1 & 0.827 & 3.7 \\
\hline 2005LF124A & $<\mathrm{RPT}$ & 5.01 & $<\mathrm{RPT}$ & 0.297 & 0.328 & 11.3 & 25.7 & 2.88 & 1.8 & 9.7 & 18.6 & 157 & 1.66 & 6.05 \\
\hline 2005MBW232A & $<\mathrm{RPT}$ & 58.5 & $<\mathrm{RPT}$ & 0.772 & 1.04 & 8.52 & 34.4 & 4.6 & 7.59 & 9.06 & 37.3 & 80.2 & 6.05 & 8.32 \\
\hline 2005MBW245A & $<\mathrm{RPT}$ & 45.9 & $<\mathrm{RPT}$ & 1.12 & 2.57 & 14.8 & 33.7 & 7.11 & 8.54 & 13 & 52.8 & 105 & 12.4 & 9.71 \\
\hline 2005MBW254A & $<\mathrm{RPT}$ & 13.4 & $<\mathrm{RPT}$ & 1.11 & 1.6 & 24.2 & 36.1 & 8.01 & 4.25 & 17.1 & 70.1 & 147 & 13.9 & 11.2 \\
\hline 2005MBW266A & $<\mathrm{RPT}$ & 22.7 & $<\mathrm{RPT}$ & 0.88 & 1.75 & 31.3 & 35.7 & 7.14 & 3.99 & 15.2 & 49.9 & 253 & 11.8 & 10 \\
\hline 2005MBW415A & $<\mathrm{RPT}$ & 47.5 & $<\mathrm{RPT}$ & 0.853 & 0.81 & 6.27 & 22.3 & 7.54 & 12.3 & 8.45 & 42.5 & 65.8 & 38.1 & 6.14 \\
\hline 2005Z155A & $<\mathrm{RPT}$ & 37.1 & $<\mathrm{RPT}$ & 0.911 & 0.111 & 5.26 & 33 & 3.24 & 1.53 & 12.3 & 48.4 & 255 & 2.45 & 32.4 \\
\hline 2005Z156C & $<\mathrm{RPT}$ & 9.66 & $<\mathrm{RPT}$ & 1.03 & 0.686 & 26 & 34.1 & 7.31 & 3.29 & 16.8 & 47.3 & 160 & 8.48 & 12.2 \\
\hline 2005Z165A & $<\mathrm{RPT}$ & 144 & $<\mathrm{RPT}$ & 0.903 & 0.463 & 1.59 & 22.7 & 12.4 & 17.6 & 8.11 & 116 & 28.4 & 25 & 9.91 \\
\hline 2005Z167A & $<\mathrm{RPT}$ & 60.1 & $<\mathrm{RPT}$ & 1.42 & 0.787 & 5.82 & 21.3 & 5.8 & 8.89 & 9.62 & 51.6 & 82.7 & 19.3 & 7.23 \\
\hline 2005Z170A1 & $<\mathrm{RPT}$ & 13.6 & $<\mathrm{RPT}$ & 1.18 & 0.879 & 20.9 & 33.4 & 10.8 & 8.1 & 13.1 & 60.7 & 138 & 12.8 & 10.2 \\
\hline 2005Z170A2 & $<\mathrm{RPT}$ & 16.6 & $<\mathrm{RPT}$ & 0.627 & 0.323 & 5.83 & 24.6 & 6.2 & 8.28 & 9.6 & 34.1 & 71.2 & 8.22 & 6.42 \\
\hline 2005Z170A3 & $<\mathrm{RPT}$ & 17.8 & $<\mathrm{RPT}$ & 0.299 & 1.38 & 0.158 & 11.7 & 3.36 & 4.12 & 6.49 & 12.4 & 7.56 & 2.4 & 4.38 \\
\hline 2005Z171A & $<\mathrm{RPT}$ & 14.3 & $<\mathrm{RPT}$ & 0.646 & 0.926 & 8.34 & 29.8 & 5.35 & 7.46 & 8.86 & 41.2 & 95.8 & 6.93 & 5.91 \\
\hline 2005Z171C & $<\mathrm{RPT}$ & 11.5 & $<\mathrm{RPT}$ & 0.566 & 0.655 & 6.56 & 30.3 & 3.26 & 4.1 & 8.19 & 31.8 & 71.6 & 4.64 & 5.49 \\
\hline $2005 Z 236 A$ & $<\mathrm{RPT}$ & 13.8 & $<\mathrm{RPT}$ & 0.434 & 0.777 & 7.44 & 29.8 & 3.75 & 3.18 & 7.57 & 26.6 & 98 & 3.89 & 4.95 \\
\hline 2005Z36B & $<\mathrm{RPT}$ & 18.1 & $<\mathrm{RPT}$ & 0.434 & 0.895 & 7.02 & 30.9 & 6.32 & 3.5 & 9.03 & 26.6 & 95.3 & 4.73 & 6.22 \\
\hline 2005Z38D & $<\mathrm{RPT}$ & 18.8 & $<\mathrm{RPT}$ & 0.544 & 1.41 & 7.59 & 30.1 & 3.86 & 3.82 & 10.3 & 30 & 117 & 4.85 & 6.38 \\
\hline $2005 Z 47 A$ & $<\mathrm{RPT}$ & 22.1 & $<\mathrm{RPT}$ & 0.752 & 0.772 & 3 & 21.9 & 6.38 & 16.9 & 9.24 & 37.5 & 35.2 & 13 & 6.58 \\
\hline
\end{tabular}



$<R P T=$ value was less than reported limit-continued.

\begin{tabular}{lcccc} 
Sample Number & $\begin{array}{c}\text { Te } \\
\text { ppm }\end{array}$ & $\begin{array}{c}\text { TI } \\
\text { ppm }\end{array}$ & $\begin{array}{c}\text { U } \\
\text { ppm }\end{array}$ & $\begin{array}{c}\text { Zn } \\
\text { ppm }\end{array}$ \\
\hline 2005JEA160B & 0.206 & 0.663 & 2.93 & 63.5 \\
2005LF105A & 0.112 & 0.261 & 1.61 & 65.5 \\
2005LF124A & 0.185 & 1.04 & 2.76 & 177 \\
2005MBW232A & 0.391 & 0.978 & 5.72 & 87.2 \\
2005MBW245A & 0.373 & 1.48 & 11.5 & 126 \\
2005MBW254A & 0.334 & 1.45 & 12.3 & 287 \\
2005MBW266A & 0.295 & 1.98 & 7.58 & 43.1 \\
2005MBW415A & 0.496 & 0.762 & 12.3 & 82.7 \\
2005Z155A & $<R P T$ & 1.8 & 10.3 & 31.2 \\
2005Z156C & 0.292 & 1.29 & 9.89 & 63.8 \\
2005Z165A & 0.365 & 1.16 & 7.26 & 35 \\
2005Z167A & 0.337 & 1.01 & 8.4 & 144 \\
2005Z170A1 & 0.345 & 1.24 & 7.9 & 49.4 \\
2005Z170A2 & 0.274 & 0.748 & 5.55 & 35.2 \\
2005Z170A3 & 0.261 & 0.117 & 2.26 & 474 \\
2005Z171A & 0.371 & 0.917 & 5.43 & 61.1 \\
2005Z171C & 0.3 & 0.708 & 4.69 & 63.9 \\
2005Z236A & 0.235 & 0.974 & 4 & 93 \\
2005Z36B & 0.235 & 1.01 & 4.23 & 83.9 \\
2005Z38D & 0.284 & 1.17 & 4.88 & 116 \\
2005Z47A & 0.345 & 0.455 & 8.27 & 31.2
\end{tabular}


Table F4. Methodology and reported limits for major-, minor-, and trace-element geochemical analyses of coal and coal ash. Reported limits are at the 95 percent confidence level. Analytical methods include: ICP-MS/AES = Inductively Coupled Plasma with Mass Spectroscopy or Atomic Emission Spectroscopy and ICP-AES = Inductively Coupled Plasma with Atomic Emission Spectroscopy. Digestion: four acid digestion = HF-HNO3-HClO4 and HCl leach. NOTE: $-=$ not applicable.

\begin{tabular}{|c|c|c|c|c|c|c|}
\hline Element & $\begin{array}{l}\text { Reported } \\
\text { Limits }\end{array}$ & Units i & $\begin{array}{l}\text { Digestion } \\
\text { if applicable }\end{array}$ & $\begin{array}{l}\text { Analytical } \\
\text { Method }\end{array}$ & $\begin{array}{l}\text { ASTM } \\
\text { Standard }\end{array}$ & Comments \\
\hline Moisture & 一 & percent & - & Furnace & D3173 & \\
\hline $\mathrm{Hg}$ & 0.02 & ppm & - & - & D6414-A & \\
\hline Se & 0.2 & ppm & - & - & - & USGS in-house method \\
\hline $\mathrm{Cl}$ & 10 & ppm & - & Combustion & D6721 & Using TOX $100 \mathrm{Cl}$ analyzer \\
\hline $\mathrm{S}$ & 0.05 & percent & - & Combustion & D4239 & Using LECO \\
\hline Ashing & - & - & 一 & Furnace & D3174 & $\begin{array}{l}\text { ASTM method }\left(750^{\circ} \mathrm{C}\right) \text { plus } \\
\text { USGS method }\left(525^{\circ} \mathrm{C}\right)\end{array}$ \\
\hline $\mathrm{Al}$ & 0.02 & percent & four acid & ICP-AES & D6349 & \\
\hline $\mathrm{Ba}$ & 2 & ppm & four acid & ICP-AES & D6349 & \\
\hline $\mathrm{Be}$ & 1 & ppm & four acid & ICP-AES & D6349 & \\
\hline $\mathrm{Ca}$ & 0.02 & percent & four acid & ICP-AES & D6349 & \\
\hline Co & 2 & ppm & four acid & ICP-AES & D6349 & \\
\hline $\mathrm{Cr}$ & 2 & ppm & four acid & ICP-AES & D6349 & \\
\hline $\mathrm{Cu}$ & 2 & ppm & four acid & ICP-AES & D6349 & \\
\hline $\mathrm{Fe}$ & 0.02 & percent & four acid & ICP-AES & D6349 & \\
\hline K & 0.02 & percent & four acid & ICP-AES & D6349 & \\
\hline $\mathrm{Li}$ & 4 & ppm & four acid & ICP-AES & D6349 & \\
\hline $\mathrm{Mg}$ & 0.02 & percent & four acid & ICP-AES & D6349 & \\
\hline Mn & 2 & ppm & four acid & ICP-AES & D6349 & \\
\hline $\mathrm{Na}$ & 0.02 & percent & four acid & ICP-AES & D6349 & \\
\hline $\mathrm{Ni}$ & 4 & ppm & four acid & ICP-AES & D6349 & \\
\hline$P$ & 0.02 & percent & four acid & ICP-AES & D6349 & \\
\hline S & 0.02 & percent & four acid & ICP-AES & D6349 & \\
\hline Sc & 4 & ppm & four acid & ICP-AES & D6349 & \\
\hline Si & 0.02 & percent & four acid & ICP-AES & D6349 & \\
\hline $\mathrm{Sr}$ & 1 & ppm & four acid & ICP-AES & D6349 & \\
\hline Th & 8 & ppm & four acid & ICP-AES & D6349 & \\
\hline $\mathrm{Ti}$ & 0.02 & percent & four acid & ICP-AES & D6349 & \\
\hline V & 2 & ppm & four acid & ICP-AES & D6349 & \\
\hline Y & 1 & ppm & four acid & ICP-AES & D6349 & \\
\hline $\mathrm{Ag}$ & 2 & ppm & four acid & ICP-MS/AES & D6721 & \\
\hline As & 0.2 & ppm & four acid & ICP-MS/AES & D6721 & \\
\hline $\mathrm{Au}$ & 10 & ppm & four acid & ICP-MS/AES & D6721 & \\
\hline $\mathrm{Bi}$ & 0.1 & ppm & four acid & ICP-MS/AES & D6721 & \\
\hline $\mathrm{Cd}$ & 0.1 & ppm & four acid & ICP-MS/AES & D6721 & \\
\hline Cs & 0.1 & ppm & four acid & ICP-MS/AES & D6721 & \\
\hline $\mathrm{Ga}$ & 0.1 & ppm & four acid & ICP-MS/AES & D6721 & \\
\hline $\mathrm{Ge}$ & 0.1 & ppm & four acid & ICP-MS/AES & D6721 & \\
\hline Mo & 0.2 & ppm & four acid & ICP-MS/AES & D6721 & \\
\hline $\mathrm{Nb}$ & 0.1 & ppm & four acid & ICP-MS/AES & D6721 & \\
\hline $\mathrm{Pb}$ & 0.5 & ppm & four acid & ICP-MS/AES & D6721 & \\
\hline $\mathrm{Rb}$ & 0.1 & ppm & four acid & ICP-MS/AES & D6721 & \\
\hline $\mathrm{Sb}$ & 0.1 & ppm & four acid & ICP-MS/AES & D6721 & \\
\hline Sn & 3 & ppm & four acid & ICP-MS/AES & D6721 & \\
\hline Te & 0.1 & ppm & four acid & ICP-MS/AES & D6721 & \\
\hline $\mathrm{Tl}$ & 0.1 & ppm & four acid & ICP-MS/AES & D6721 & \\
\hline$U$ & 0.1 & ppm & four acid & ICP-MS/AES & D6721 & \\
\hline $\mathrm{Zn}$ & 3 & ppm & four acid & ICP-MS/AES & D6721 & \\
\hline
\end{tabular}


This page intentionally left blank. 


\section{Appendix G}

\section{Alaska Resource Data File occurrences in the southern half of the Fairbanks A-4 Quadrangle}

Alaska Resource Data File (ARDF) occurrences listed in Freeman and Schaefer (2001) and located in the Liberty Bell area were located in the field and described (table G1). 
This page has intentionally been left blank. 


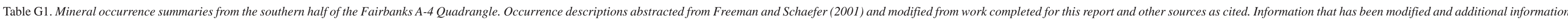

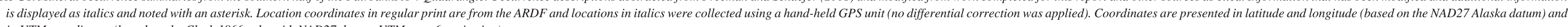
in UTM coordinates (based on the Clark 1866 spheroid, NAD27 datum, UTM zone 6 projection).

\begin{tabular}{|c|c|c|c|c|c|c|c|c|c|c|}
\hline $\begin{array}{l}\text { ARDF } \\
\text { Number }\end{array}$ & Latitude & Longitude & $\begin{array}{l}\text { UTM } \\
\text { Easting }\end{array}$ & $\begin{array}{l}\text { UTM } \\
\text { Northing }\end{array}$ & Occurrence Name & $\begin{array}{l}\text { Deposit model, occurrence type, } \\
\text { status }\end{array}$ & Major (Minor) Commodities & Ore and gangue minerals & Comments & $\begin{array}{l}\text { Mineralized } \\
\text { Samples (Athey } \\
\text { and others, 2005) }\end{array}$ \\
\hline FB126 & 64.050 & -149.000 & 402359 & 7103922 & Cody Creek & Placer Au occurrence, inactive & $\mathrm{Au}$ & Gold & & \\
\hline FB127 & 64.030 & -148.970 & 403754 & 7101649 & $\begin{array}{l}\text { Moose Creek; Big } \\
\text { Moose Creek; Keys; } \\
\text { Triple Xs }\end{array}$ & Placer Au-PGE mine, inactive & $\mathrm{Au}(\mathrm{Hg}, \mathrm{Pt}, \mathrm{Sn}, \mathrm{W})$ & $\begin{array}{l}\text { Cassiterite, cinnabar, gold, platinum, } \\
\text { scheelite }\end{array}$ & & \\
\hline FB128 & 64.030 & -148.950 & 404731 & 7101619 & Little Moose Creek & Placer Au mine, inactive & $\mathrm{Au}$ & Gold, scheelite & & \\
\hline FB129 & 64.050 & -148.940 & 405287 & 7103832 & $\begin{array}{l}\text { Rambler; Barlow; } \\
\text { Koska }\end{array}$ & $\begin{array}{l}\text { Simple Sb deposit prospect, } \\
\text { inactive }\end{array}$ & $A u^{*}, \mathrm{Ag}, \mathrm{As}, \mathrm{Sb},(P b)^{*}$ & $\begin{array}{l}\text { Arsenopyrite*, galena, gold, stibnite in } \\
\text { quartz veins }\end{array}$ & $\begin{array}{l}\text { Mineralized float of quartz-arsenopyrite } \\
\text { vein, quartz vein in altered granite, and } \\
\text { hornfelsed carbonaceous material was } \\
\text { found } 1,200 \text { feet west of ARDF location }\end{array}$ & 2005MBW363A \\
\hline FB130 & 64.073 & -148.864 & 409092 & 7106300 & $\begin{array}{l}\text { Unnamed (near } \\
\text { Spruce Creek) }\end{array}$ & & $\mathrm{Au}(\mathrm{Ag}, \mathrm{Pb}, \mathrm{Sb})$ & $\begin{array}{l}\text { Arsenopyrite, gold, jamesonite, scorodite } \\
\text { in quartz veins }{ }^{*}\end{array}$ & $\begin{array}{l}\text { Several prospect pits in the headwaters } \\
\text { area of Spruce Creek contain } \\
\text { arsenopyrite and scorodite mineralized } \\
\text { quartz veins; no locality was found at the } \\
\text { ARDF location. }\end{array}$ & 2005JEA49A \\
\hline FB131 & 64.048 & -148.927 & 405897 & 7103538 & Moose Creek & & $\mathrm{Au}, A g^{*}, A s^{*}, C u^{*}$ & Arsenopyrite, pyrite in granodiorite* & $\begin{array}{l}\text { New coordinates are for a mineralized } \\
\text { dike sample. Local placer miners report } \\
\text { that gold is recoverable by processing } \\
\text { quartz-tourmaline veins with a small } \\
\text { crusher and gravity separation. }\end{array}$ & 2005MBW50A \\
\hline FB132 & 64.050 & -148.840 & 410168 & 7103687 & Liberty Bell & $\begin{array}{l}\text { Au skarn, polymetallic vein* } \\
\text { mine, inactive }\end{array}$ & $\mathrm{Ag}, \mathrm{Au}, \mathrm{Bi}, \mathrm{Cu}, A s^{*}$ & $\begin{array}{l}\text { Arsenopyrite, bismuthinite, bornite, } \\
\text { chalcopyrite, covellite, enargite, galena, } \\
\text { gold, kobellite, loellingite, malachite, } \\
\text { pyrrhotite, pyrite, sphalerite, tennantite, } \\
\text { ullmannite in actinolite and phlogopite } \\
\text { skarn and quartz tourmaline veins }\end{array}$ & $\begin{array}{l}\text { Of the described occurrences in the } \\
\text { ARDF only selected mineralized areas in } \\
\text { the Northwest Copper zone were } \\
\text { sampled for trace-metal geochemistry. }\end{array}$ & $\begin{array}{l}\text { 2005LF228A, } \\
\text { 2005LF230A }\end{array}$ \\
\hline FB133 & 64.040 & -148.830 & 410624 & 7102559 & Eva Creek & Placer Au mine & Au $(\mathrm{V}$ & Gold, scheelite, wolframite & & \\
\hline FB134 & 64.100 & -148.830 & 410816 & 7109243 & Rex Creek & Placer Au mine, inactive & $\mathrm{Au}(\mathrm{Cu}, \mathrm{Sb})$ & Chalcopyrite, gold, pyrite, stibnite & & \\
\hline FB135 & 64.070 & -148.720 & 416086 & 7105751 & $\begin{array}{l}\text { Unnamed (near } \\
\text { California Creek) }\end{array}$ & $\begin{array}{l}\text { Simple Sb deposit prospect, } \\
\text { inactive }\end{array}$ & $\mathrm{Sb}(\mathrm{W})$ & $\begin{array}{l}\text { Ferberite, stibnite, wolframite in quartz } \\
\text { vein }\end{array}$ & $\begin{array}{l}\text { The occurrence described in the ARDF } \\
\text { was not found }\end{array}$ & \\
\hline FB136 & 64.060 & -148.720 & 416056 & 7104637 & California; Danzinger & Polymetallic vein mine, inactive & $\mathrm{Au}, A s^{*}(\mathrm{Ag}, \mathrm{Bi}, \mathrm{Cu}, \mathrm{Pb}, \mathrm{Sb})$ & $\begin{array}{l}\text { Arsenopyrite, bismuthinite, chalcopyrite, } \\
\text { galena, gold, jamesonite, pyrite, stibnite in } \\
\text { quartz (tourmaline) vein* }\end{array}$ & $\begin{array}{l}\text { The occurrence described in the ARDF } \\
\text { was not found, but several occurrences of } \\
\text { shear zones with quartz (tourmaline) } \\
\text { arsenopyrite (pyrite) veins were sampled } \\
\text { in the immediate vicinity. }\end{array}$ & $\begin{array}{l}\text { 2005MBW292A, } \\
\text { 2005MBW296B, } \\
\text { 2005MBW298A, } \\
\text { 2005MBW303A, } \\
\text { 2005MBW407A }\end{array}$ \\
\hline FB137 & 64.050 & -148.720 & 416026 & 7103523 & California Creek & Placer Au-PGE mine, inactive & $\mathrm{Au}(\mathrm{Hg}, \mathrm{Pt})$ & Cinnabar, gold, platinum group metals & & \\
\hline FB138 & 64.030 & -148.690 & 417431 & 7101256 & McAdam Creek & Placer Au mine, inactive & $\mathrm{Au}$ & Gold & & \\
\hline FB139 & 64.050 & -148.620 & 420907 & 7103395 & $\begin{array}{l}\text { Unnamed (at head of } \\
\text { Eagle Creek) }\end{array}$ & $\begin{array}{l}\text { Simple Sb deposit occurrence, } \\
\text { inactive }\end{array}$ & $\mathrm{Sb}(\mathrm{Ag}, \mathrm{Au})$ & Stibnite, galena, gold, (pyrite) in quartz & $\begin{array}{l}\text { The occurrence described in the ARDF } \\
\text { was not found }\end{array}$ & \\
\hline FB140 & 64.100 & -148.520 & 425922 & 7108846 & Daniels Creek & Placer Au mine, inactive & $\mathrm{Au}$ & & & \\
\hline
\end{tabular}




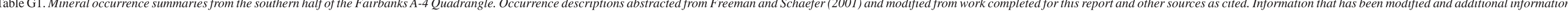

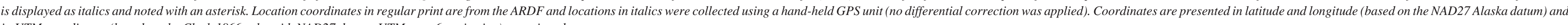
in UTM coordinates (based on the Clark 1866 spheroid, NAD27 datum, UTM zone 6 projection)-continued.

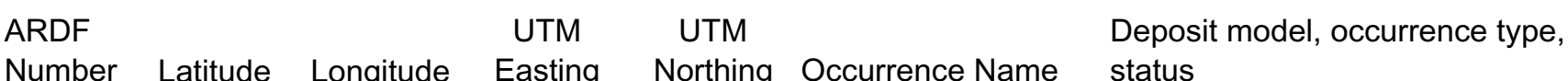

FB142 $64.050-148.550$

424324

7103310 Unnamed (head of

Polymetallic vein Fourth of July Creek)

FB143 $\quad 64.030 \quad-148.540$

FB144 $64.000 \quad-148.550$

new $^{*} \quad 64.085 \quad-148.586$

4247597101070 Fourth of July Creek; Placer Au mine, inactive July Creek

241897097740 Homestake Creek Placer Au mine, inactive

4226647107253 Unnamed (head of Polymetallic vein prospect, Daniels Creek)*

\section{$A g^{*}, \mathrm{Sb}, A u, P b^{*}$}

$\mathrm{Au}(\mathrm{Ag}, \mathrm{Pb}, \mathrm{Sb})$

$A u, A g(A s, B i, P b, S b)$
Stibnite, cerusite, stibiconite in quartz veins *

\section{Gold, jamesonite}

Gold

Arsenopyrite, pyrite, stibnite in quartztourmaline veins
Mineralized

Comments and others, 2005)

Scattered veins in multiple locations on ridges noth and west of the headwaters 2005MBW174A 2005MBW224A

Veins widespread in Paleozoic metasedimentary rocks associated with 2005LF61B, Cretaceous granite dikes on the ridges 2005LF75B, around headwaters of Daniels Creek. 2005LF75C, Several trenches and hand-dug pits are 2005LF75E, the result of exploration work by 2005LF77A, Cominco, Inc. and NERCO in late 1980s 2005LF78A, (L.K. Freeman, written communication, 2005LF79B 2006)

Vein in cliff on east side of Totatlanika 2005LF141B 